\title{
Geology and Uranium Deposits, Shirley Basin Area, Wyoming
}

GEOLOGIGAL SURVEY PROFESSIONAL PAPER 745 
GEOLOGY AND URANIUM DEPOSITS,

SHIRLEY BASIN AREA, WYOMING 


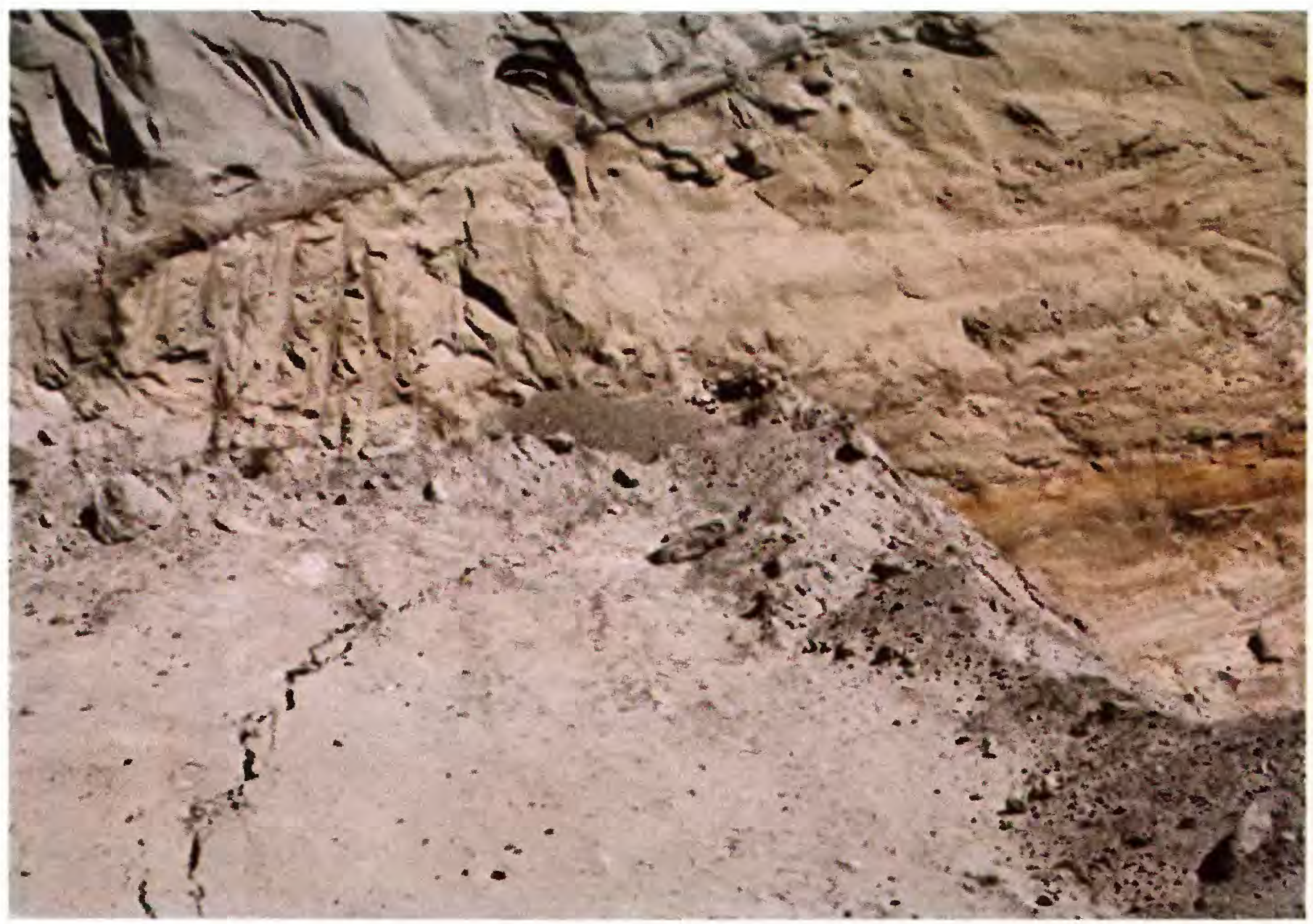

Uranium ore roll at contact of altered-sandstone tongue (yellowish green) and unaltered sandstone (gray), Petrotomics Co. Section 9 pit, phase 7 , north wall. Height across nose of roll is about 7 feet. 


\section{Geology and Uranium Deposits,}

Shirley Basin Area, Wyoming

By E. N. HARSHMAN

GEOLOGIGAL SURVEY PROFESSIONALA PER 745

A study of the geochemistry and genesis

of the uranium deposits and their

relation to regional stratigraphy, structure, and hydrology

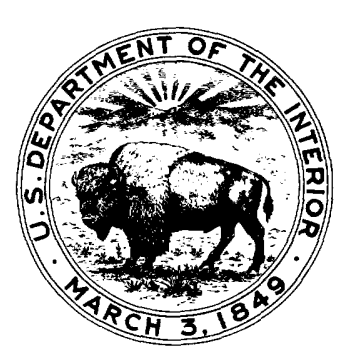




\section{UNITED STATES DEPARTMENT OF THE INTERIOR \\ CECIL D. ANDRUS, Secretary}

\section{GEOLOGICAL SURVEY}

V. E. McKelvey, Director

Library of Congress catalog-card No. 72-600017

First Printing 1972

Second Printing 1978

For sale by the Branch of Distribution, U.S. Geological Survey 1200 South Eads Street, Arlington, VA 22202 


\section{CONTENTS}

Abstract.

Introduction..

Location and accessibility

Physical features.

Local industries.

Climate and vegetation

Early culture.

Previous work

History and fieldwork

Acknowledgments.

Stratigraphy.

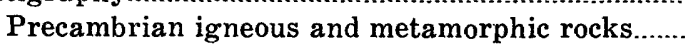

Paleozoic

Madison Limestone

Post-Madison erosion

Casper Formation.

Paleozoic and Mesozoic

Goose Egg Formation

Mesozoic

Red Peak Formation.

Alcova Limestone.

Jelm Formation.

Sundance Formation.

Morrison Formation................................

Cloverly Formation.

Thermopolis and Mowry Shales.......................

Frontier Formation

Niobrara Formation

Steele Shale

Cenozoic.

Fort Union(?) Formation

Wind River Formation

Wagon Bed Formation.

White River Formation

Arikaree Formation

High terrace gravel

Low terrace gravel

Alluvium

Silicification of sedimentary rocks

Structure

\begin{tabular}{|c|c|c|}
\hline Page & & Page \\
\hline 1 & Structure - Continued & \\
\hline 2 & Landslides................. & 35 \\
\hline 2 & Faults........... & 35 \\
\hline 2 & Folds & 36 \\
\hline 4 & Ground water... & 37 \\
\hline 5 & Ore deposits..... & 41 \\
\hline 5 & 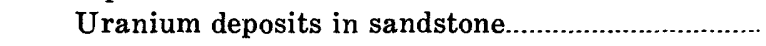 & 41 \\
\hline 6 & 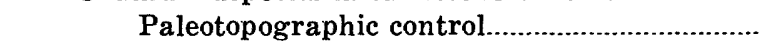 & 42 \\
\hline 6 & Relation to altered-sandstone tongues............. & 44 \\
\hline 7 & Character of alteration & 46 \\
\hline 7 & The ore bodies. & 50 \\
\hline 8 & 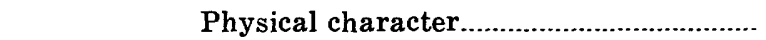 & 50 \\
\hline 9 & Mineralogy and mineral distribution....... & 53 \\
\hline 11 & Paragenesis of the ore and & \\
\hline 11 & associated minerals & 57 \\
\hline 12 & Distribution of elements and compounds & 58 \\
\hline 13 & Uranium and equivalent uranium.... & 59 \\
\hline 13 & Iron & 60 \\
\hline 13 & Selenium & 62 \\
\hline 13 & 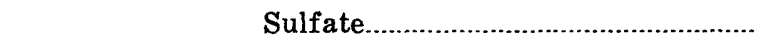 & 63 \\
\hline 13 & Carbon & 63 \\
\hline 14 & 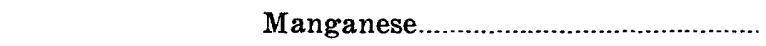 & 63 \\
\hline 14 & 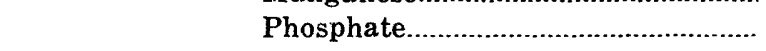 & 63 \\
\hline 15 & Arsenic & 65 \\
\hline 16 & Copper & 65 \\
\hline 17 & Vanadium & 65 \\
\hline 18 & Beryllium & 65 \\
\hline 18 & Lead & 66 \\
\hline 18 & 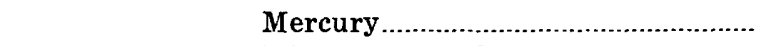 & 66 \\
\hline 19 & Miscellaneous elements.......................... & 66 \\
\hline 19 & 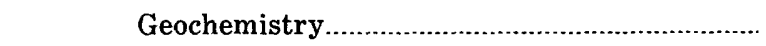 & 67 \\
\hline 19 & Solution, transportation, and & \\
\hline 24 & deposition of elements........... & 68 \\
\hline 26 & Genesis of the deposits................ & 70 \\
\hline 32 & Age. & 73 \\
\hline 34 & 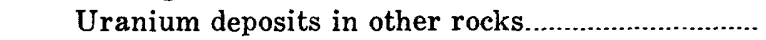 & 73 \\
\hline 34 & Monazite deposits in Tertiary rocks & 74 \\
\hline 34 & 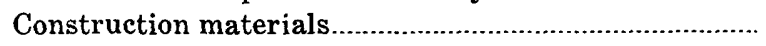 & 74 \\
\hline 34 & References cited & 74 \\
\hline 35 & Index & 79 \\
\hline
\end{tabular}

\section{ILLUSTRATIONS}

Frontispiece. Photograph of uranium ore roll at contact of altered-sandstone tongue and unaltered sandstone.

Figure

1. Index map of Wyoming, showing Shirley Basin area..

2. Map showing limits of the Shirley Basin area, and some of the geographic features described in this report. 
Figures 3-22. Photographs:

3. Erosion in Bates Hole.

4. Tipi rings in eastern part of Basin.

5. Ring of unknown designation associated with tipi rings.

6. Diabase dikes intruding Precambrian granite..

7. Basal sandstone unit of the Madison Limestone.

8. Solution breccia in well-developed karst surface.

9. Crossbedded sandstone near base of Cloverly Formation

10. Ripple-marked mudstone in middle unit of Cloverly Formation.

11. Large granite boulders in basal conglomerate of Wind River Formation

12. Petrotomics Co. Section 9 pit, showing lithology of Wind River Formation.

13. Petrotomics Co. Section 15 pit, showing lithology of Wind River Formation

14. Petrotomics Co. Section 15 pit, showing contorted lignite..

15. Basal part of the White River Formation.

16. White River Formation.

17. Diastem between the upper and lower members of the White River Formation

18. Basal part of upper member of White River Formation.

19. Basal part of Arikaree Formation...

20. Thick old alluvium.

21. Large landslide block in the White River Formation

22. Gentle fold in the White River Formation.

23. Contour map of the top of the ground-water table in part of the Shirley Basin.

24. Photograph showing small roll on the upper surface of an altered-sandstone tongue

25. Map of part of the Shirley Basin, showing paleogeology and paleotopography

26. Photograph showing channel sandstones cutting lignite and siltstone beds.....

27. Map showing relation of altered-sandstone tongues to paleotopography.

28. Graph showing cumulative and frequency distribution curves for three samples from the ore-bearing sandstone interval

29. Photograph showing contact between unaltered sandstone and altered-sandstone tongue

30. Sections showing simple "C" roll and two complex rolls.

31. Section of small ore body on bottom of altered-sandstone tongue

32-34. Photographs:

32. Crosscutting contact between altered sandstone and ore

33. Ore at edge of altered-sandstone tongue.

34. Strong control of ore by permeable crossbeds.

35-38. Photomicrographs :

35. Replacement of feldspar by pyrite....

36. Pyrite and uraninite in high-grade ore.

37. Pyrite-marcasite and uraninite rims on quartz sand grains

38. Twinned ferroselite crystals..

39. Photograph of calcite-cemented ore-bearing sandstone, showing carbonaceous material in core.

40. Photomicrographs showing replacement of feldspar by calcite in high-grade ore.

41. Photomicrograph of calcite-cemented concretion, showing rim and outer skin of uraninite.

42. Sketch showing graphic summary of mineral deposition in the Shirley Basin.

43. Cross sections at the edges of altered-sandstone tongues, showing uranium and equivalent-uranium contents.

44. Graph showing equilibrium relations of 175 samples of mineralized sandstone from Shirley Basin.......

45-50. Sections through ore bodies showing:

45. Contents of uranium, of ferrous, ferric and total iron, and of ferrous iron in sulfide and nonsulfide minerals.

46. Selenium contents.

47. Uranium and sulfate contents

48. Organic-carbon, mineral-carbon, and manganese contents.

49. Uranium, selenium, arsenic, and sulfide-sulfur contents.

50. Copper and vanadium contents.

51. Diagrams showing possible paths of circulation of ore-bearing solutions in the Shirley Basin area....

52. Diagram showing postulated $\mathrm{Eh}$ and $\mathrm{pH}$ conditions for a unit of solution during transportation and deposition of uranium and other elements.

53. Graph showing total $\mathrm{Pb} / \mathrm{U}$ ratios of 15 high-grade ore samples from the Shirley Basin. 


\section{TABLES}

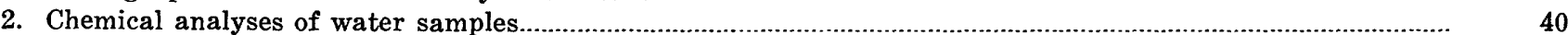

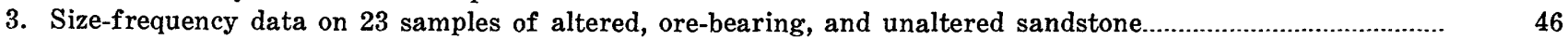

4. Physical and mineralogical data on 39 samples of unaltered, altered, and ore-bearing sandstone..................

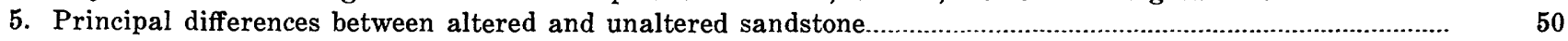

6. Uranium and pyrite contents of some Shirley Basin ores from Utah Construction and Mining Co. mine and Petrotomics Co. Section 9 pit.

7. Uranium and phosphate contents and $\mathrm{U} / \mathrm{P}_{2} \mathrm{O}_{5}$ ratios for a suite of samples from the Petrotomics Co. Section 9 pit

8. Uranium leached from samples of igneous rocks from mountain ranges that flank the Shirley Basin.......... 



\title{
GEOLOGY AND URANIUM DEPOSITS,
}

\section{SHIRLEY BASIN AREA, WYOMING}

\author{
By E. N. HARSHMAN
}

ABSTRACT

The Shirley Basin area is in Albany, Carbon, Converse, and Natrona Counties, Wyo., about 35 airline miles south of Casper. It is accessible over two improved and many local dirt roads. The area may be divided into four geographic units or subareas: the Shirley Basin, Bates Hole, Bates Creek drainage area, and the Laramie Mountains. Perennial streams drain all four sub-areas, although summer flows are low.

Maximum relief is in Bates Hole, an erosional depression, where altitudes range from about 6,100 feet along Stinking Creek to about 8,000 feet on Chalk Mountain in the southwest corner. Altitudes in the Shirley Basin, the subarea of economic interest, range from about 6,900 feet along the Little Medicine Bow River on the southeast to about 7,800 feet along the north rim of the basin.

The Shirley Basin contains one of the major uranium ore reserves in the United States, and as of late 1969 the deposits were being mined by Kerr McGee Corp., Petrotomics Co., and Utah Construction and Mining Co. Most of the ore is milled locally.

Rocks in the Shirley Basin area range in age from Precambrian to Quaternary. The Precambrian rocks crop out in the core of the Laramie Mountains and are part of an ancient terrane that was folded, metamorphosed, and subsequently invaded by granitic batholiths and mafic dikes. The intrusive activity was followed by a long period of erosion, and by the end of Precambrian time the region was reduced to a nearly flat surface.

Throughout the Paleozoic Era and much of the Mesozoic, the area was part of a stable foreland that lay along the east side of the Cordilleran geosyncline. Epicontinental seas repeatedly transgressed the area from the west and northwest, and a thick series of marine, littoral, and continental sediments was deposited in the Shirley Basin area. The formations, from oldest to youngest, are (1) the Madison Limestone of Mississippian age, (2) the Casper Formation of Pennsylvanian and Permian age, (3) the Goose Egg Formation of Permian and Triassic age, (4) the Red Peak, Alcova, and Jelm Formations of Triassic age, and (5) the Sundance and Morrison Formations of Jurassic age.

Near the end of the Jurassic Period the western shores of the epicontinental seas migrated eastward, and great amounts of clastic material, eroded from highlands to the west, were deposited along the shores of, or in, the Cretaceous seas. From oldest to youngest the rocks of Cretaceous age of the Shirley Basin are (1) the Cloverly Formation, principally of continental origin, and (2) the Thermopolis, Mowry, Frontier, Niobrara, and Steele Formations, principally of marine and deltaic origin.

The Laramide orogeny deformed the area at the close of the Cretaceous, and the seas withdrew for the last time. Erosion of the newly formed mountains began in the Paleocene and continues now. The clastic debris that had been eroded from the highlands to the east and west of the Shirley Basin was deposited on an erosional surface which was cut into Cretaceous and older rocks. Formations of Tertiary age present in the area are, from oldest to youngest: Fort Union(?), Wind River, Wagon Bed, White River (two members), and Arikaree. Quaternary formations include several stages of stream gravels and alluvium.

The pre-Tertiary rocks have been folded and faulted on a minor scale. A syncline trends southeastward through the western part of the area. Dips of the rocks on the eastern limb of the syncline are $2^{\circ}-12^{\circ} \mathrm{SW}$., and on the western limb the dips are northeastward and somewhat flatter. The area was domed in late Tertiary time; exposed Tertiary rocks dip about $1^{\circ} \mathrm{N}$. and have been broken by a few faults that show small displacements.

The ground-water table in the area lies from a few feet to 100 feet or more below the surface. Ground water is tributary to the surface drainage system and has a southerly gradient of 10-30 feet per mile. The principal anions in the ground water are sulfate and bicarbonate; radioelements include uranium, radium, and radon. Measurements of $\mathrm{pH}$ range from 6.6 to 8.3 and have a mean and median of about 7.7.

The uranium deposits in the Shirley Basin are of major significance and constitute about one-sixth of the Nation's ore reserves. They are in the Wind River Formation of early Eocene age in two thick sandstone intervals which are separated by siltstone and silty claystone beds. The deposits bound large tongues of altered sandstone, commonly in so-called roll forms at the margins and as tabular layers on the top and bottom surfaces, a spatial relationship useful as an exploration guide. Ore bodies range from a few hundred tons to a few hundred thousand tons and in ore grade, as mined, from 0.1 to 0.7 percent $\mathrm{U}_{3} \mathrm{O}_{8}$. High-grade ore may contain as much as 20 percent $\mathrm{U}_{3} \mathrm{O}_{8}$. 
The edges of the altered-sandstone tongues in the Shirley Basin area separate oxidized iron minerals within the tongues from reduced iron and uranium minerals in the material surrounding them. For this and other reasons, the ore-bearing solutions that produced this alteration are thought to have been oxidizing. The geochemistry of the ore and associated minerals and the arkosic nature of the ore-bearing sandstones suggest that these solutions were alkaline. Hydrogen sulfide of biogenic origin is believed to have played an important part in forming the ore deposits, although precipitation of the ore minerals may have been caused by nonbiogenic reactions. Ore deposition probably took place at least 500 feet and perhaps as much as 1,500 feet below the ground surface.

Uraninite is the only identified ore mineral; accessory minerals are abundant pyrite and minor amounts of marcasite, calcite, hematite, native (?) selenium, and an unidentified sulfate mineral. Altered sandstone contains goethite, limonite, and ferroselite. Uraninite and pyrite coat sand grains and fill interstices between sand grains; there is some replacement of the arkose by pyrite.

Many elements in the ore, and in altered and unaltered sandstone near ore, show a systematic distribution about the edge of the altered-sandstone tongue. These elements include uranium, iron, selenium, carbon, beryllium, sulfur, copper, and vanadium.

The sequence of events that gave rise to the Shirley Basin ore deposits is believed to have been as follows: (1) Downward percolation of vadose waters that leached uranium from weathered granite in nearby highlands and (or) from the tuffaceous constituents of rocks overlying the ore-bearing intervals, (2) lateral movement of this water through the most permeable beds of the Wind River Formation, (3) reaction of the oxidizing ore-bearing solutions with the rocks through which they moved, causing a lowering of the Eh and $\mathrm{pH}$ of the solutions and deposition of the ore and associated minerals, and (4) passage of the spent ore-bearing solutions beyond the zone of deposition and out of the basin.

The zone of ore deposition is considered to have been a dynamic feature, migrating basinward by oxidation and solution on the updip side of the ore body and reduction and deposition on the downdip side. A rather sharp drop in the $\mathrm{pH}$ of the ore-bearing solution probably occurred at the edge of the altered sandstone tongue when pyrite was oxidized by the ore-bearing solutions.

The age of the Shirley Basin uranium deposits is not well documented, but the best evidence suggests that it is about 18 million years.

\section{INTRODUGTION}

\section{LOCATION AND ACCESSIBILITY}

The Shirley Basin area is in southeastern Wyoming in Carbon, Natrona, Albany, and Converse Counties (fig. 1). Casper, the second largest town in Wyoming, is about 33 airline miles north of the center of the area, and Medicine Bow, on the main line of the Union Pacific Railroad, is 32 miles to the south.

The area is traversed by several improved roads and many unimproved roads and trails (fig. 2). State
Highway 487, a paved all-weather road that is maintained throughout the winter, passes from north to south through the western part of the area. The old Casper-Medicine Bow road serves the eastern and north-central parts of the area; it is graded, gravel surfaced, and, in part, maintained throughout the winter. The Shirley Ridge road, which connects the Shirley Basin mining area with State Highway 487, passes from east to west through the central part of the area; it is graded, gravel surfaced, and maintained throughout the winter. Most of the other roads and trails are impassable during periods of heavy snow, and some are impassable to all but fourwheel-drive vehicles, even in the summer months.

\section{PHYSICAL FEATURES}

The Shirley Basin area lies between the Laramie Mountains on the northeast and the Shirley Mountains on the southwest. It is an area of low to moderate relief that comprises four distinct geographic units (fig. 2). These and other physical features are shown on the geologic map of the Shirley Basin area (Harshman, 1968b).

The Shirley Basin, the focal point of this investigation, is by far the largest and economically the most important of these geographic units. The basin is not well defined, but generally it is considered to lie in the Little Medicine Bow River drainage and to be bounded on the northwest by Bates Hole, on the north by the south edge of the Bates Creek drainage area (Dugway Rim), and on the east by the west flank of the Laramie Mountains. The south and southwest boundaries are outside of the area investigated. In this report, about 10 square miles of terrain near the southwest corner of the area is considered a part of the Shirley Basin even though it is drained by Dry Creek, a westward-flowing tributary of the North Platte River. The Shirley Basin is an area of low relief eroded in rocks of Cretaceous and Tertiary age. Altitudes range from slightly below 6,900 feet along the Little Medicine Bow River in the southeastern part of the basin to about 7,800 feet on the Dugway Rim at the north boundary. The Little Medicine Bow River, a perennial stream that rises on the west flank of the Laramie Mountains, flows southward through the basin and joins the westward-flowing Medicine Bow River near the town of Medicine Bow. Owing to the low, rolling character of the terrain, exposures in the Shirley Basin are poor except in very limited areas along the Little Medicine Bow River and its major tributaries and along the southern slope of the Dugway Rim. 
Bates Hole, a prominent erosional feature in the northwestern part of the area, is drained by Stinking Creek and its tributaries. Stinking Creek is an intermittent stream that flows northward and joins the North Platte River about 30 miles northwest of the area. Relief in Bates Hole is moderate; altitudes range from about 6,100 feet along Stinking Creek at the north edge of the area to slightly over 8,000 feet on Chalk Mountain near its western edge. The floor of Bates Hole is composed of Cretaceous shales; in the walls are excellent exposures of Tertiary rocks ranging in age from Eocene to Miocene. Although Stinking Creek is a small intermittent stream, erosion of the soft rocks composing the rim of Bates Hole has been exceedingly rapid. That piñon pine trees are supported on their stiltlike roots and have their crowns as much as 6 feet above the present ground surface (fig. 3) indicates that the rim of
Bates Hole has receded as much as 10 feet during the lifespan of the trees-probably not more than a few hundred years.

The Bates Creek drainage area lies north of the Shirley Basin, east of Bates Hole, and west of the Laramie Mountains. It is a high-standing almost terracelike area drained by northward-flowing Bates Creek and carved in rocks of Tertiary age. Altitudes range from about 7,000 feet on the northwest to about 7,800 on the east. Steep-walled narrow canyons dissect the northwestern part of the area; elsewhere dissection has been minor, and the component rocks are poorly exposed. Bates Creek reservoir, in the north-central part of the area, stores water for a short time after the spring runoff, but owing to excessive leakage through underlying permeable rocks, it is generally dry by midsummer.

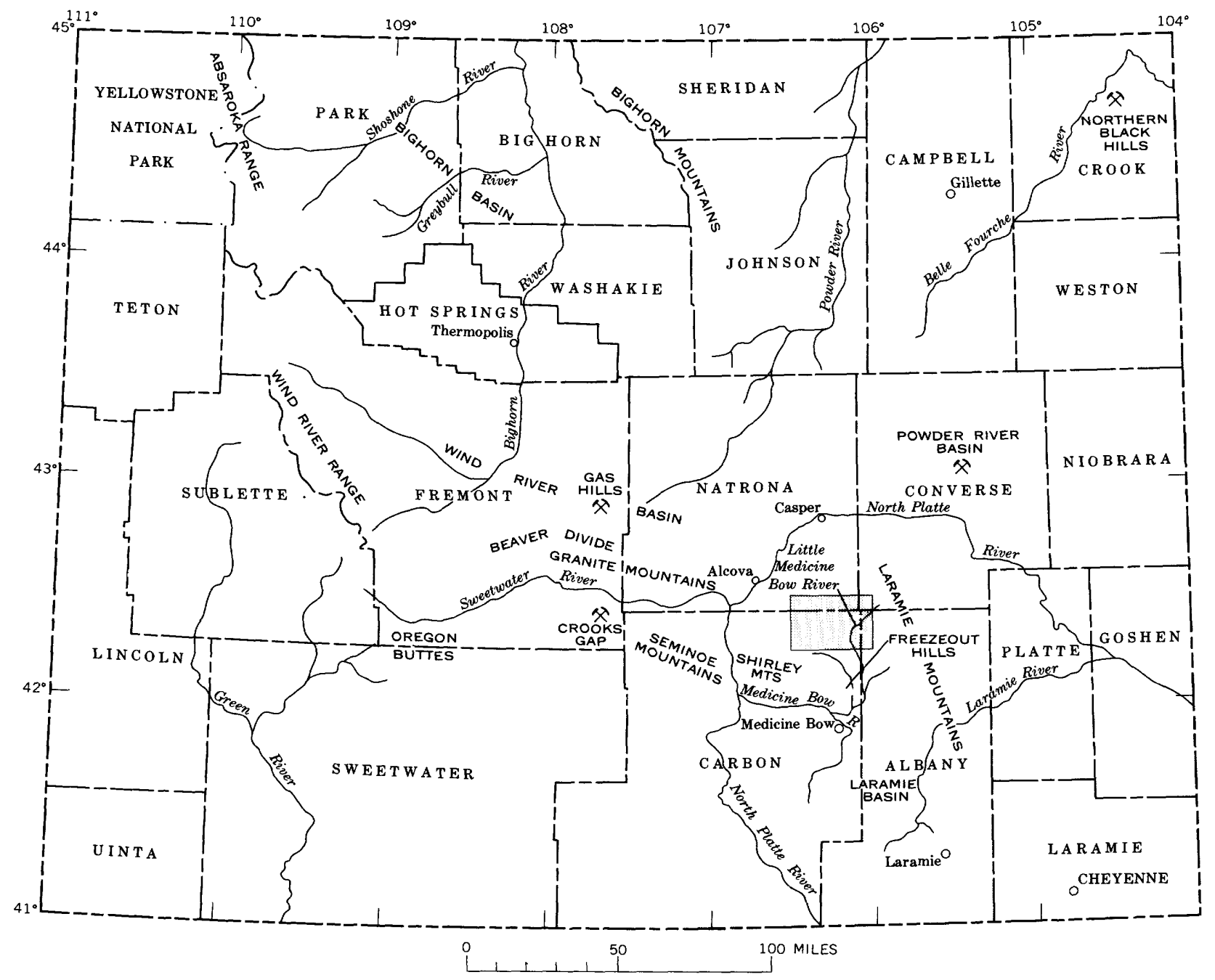

$464-1700-72-2$

Figure 1. - Shirley Basin area (shaded), Wyoming. 


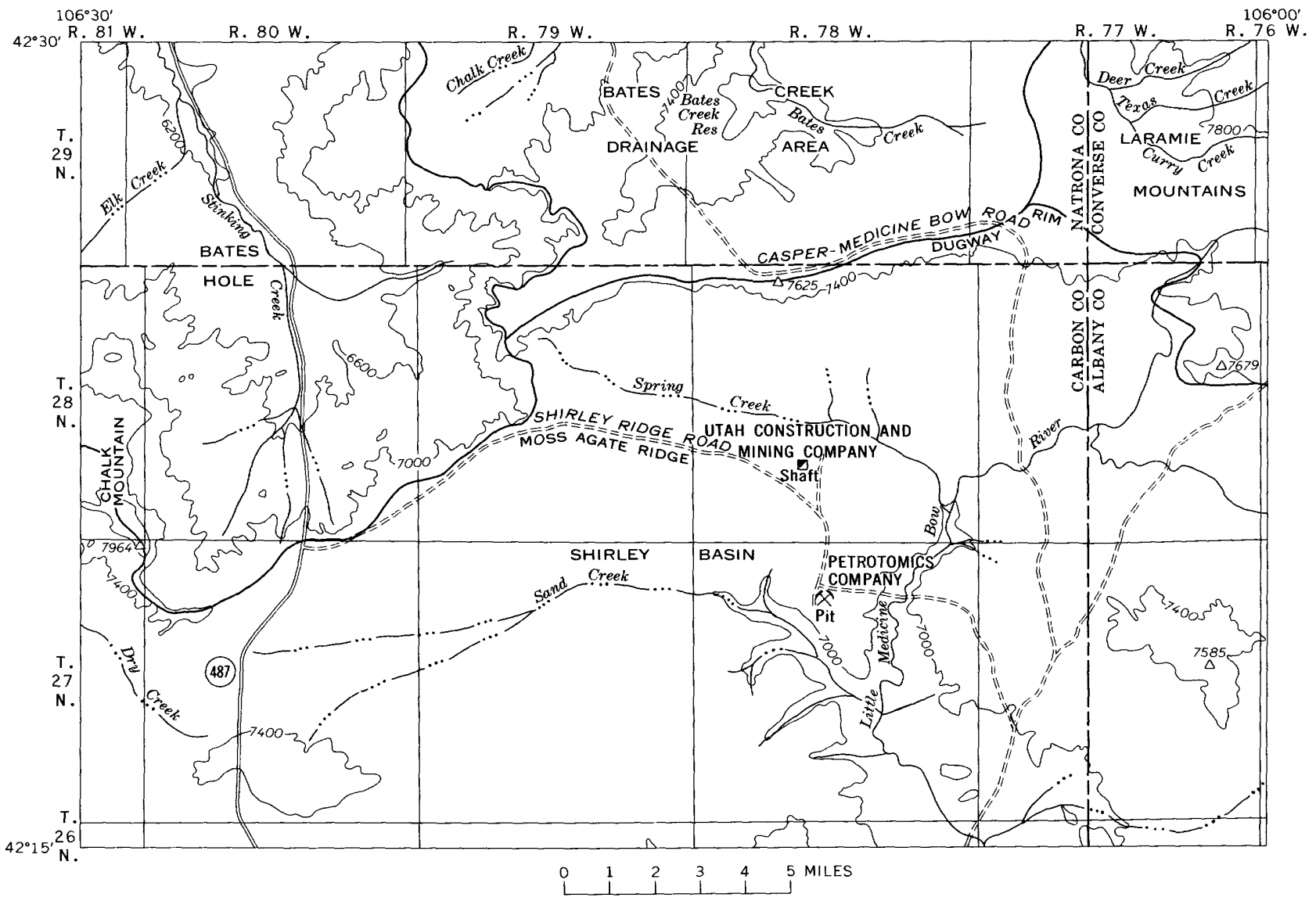

FIGURE 2. - Limits of the Shirley Basin area, and some of the geographic features described in this report.

The west flank of the Laramie Mountains extends into the northeastern part of the mapped area. Exposed here are coarse-grained granitic rocks, diabase dikes, and metamorphic rocks of Precambrian age and limestone, sandstone, quartzite, and shale of Paleozoic age. Altitudes range from about 7,200 feet along the toe of the west flank of the Laramie Mountains to slightly above 8,400 feet in the northeast corner of the mapped area.

The west flank of the Laramie Mountains is dissected by numerous steep-walled canyons, some of which were cut by early Tertiary streams. These canyons were subsequently filled with clastic sediments, principally of Oligocene (White River) age. Recent erosion has removed, or is removing, this old canyon fill. The reexcavation of the higher reaches of the early Tertiary drainage system and the superimposition of the present drainage system on this old system have produced drainage abnormalities. For example, in the northeast corner of the mapped area Deer, Texas, and Curry Creeks flow southwestward down the west flank of the Laramie Mountains to an area about 3 miles west of the topographic divide. Here Curry Creek joins Texas Creek and Texas Creek joins Deer Creek. Deer Creek then reverses its direction of flow, passes eastward through the topographic divide in a steep-walled canyon, and discharges into the North Platte River at the foot of the east slope of the Laramie Mountains.

\section{LOCAL INDUSTRIES}

Mining and sheep and cattle grazing are the principal enterprises in the area. Winters are severe, and grazing is limited to the summer months.

In late 1968 two mines were operating in the Shirley Basin. The Petrotomics Co., after terminating mining in sec. 9 , was operating an open-pit mine in sec. 15 , T. 27 N., R. $78 \mathrm{~W}$.; the ore was being processed on the property. In sec. 28, T. 28 N., R. 78 W., the Utah Construction and Mining Co. was extracting uranium in situ by introducing sulfuric acid through holes drilled to the ore-bearing sandstone, pumping out the uranium-bearing solution, and removing the uranium by ion exchange. Additional open-pit mines 
are planned by Utah Construction and Mining Co. and by Kerr-McGee Corp.

Tourism is minimal, and the area has no commercial establishments where room, board, and fuel for vehicles may be purchased. The area is hunted for sage grouse, deer, and antelope (American pronghorn).

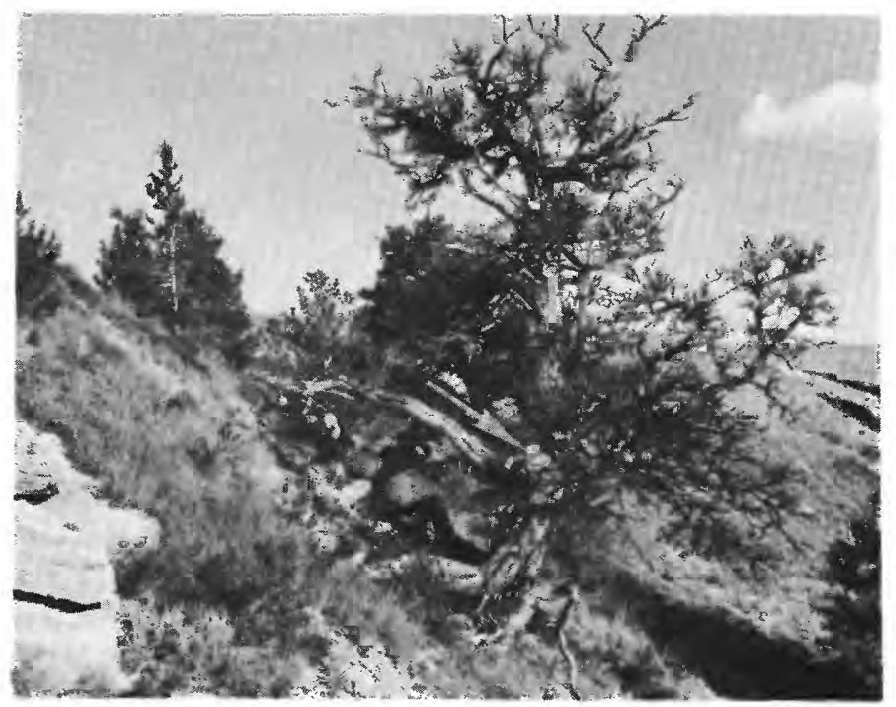

Figure 3. - Piñon pine tree killed by erosion in Bates Hole. Crown of tree (arrow) about 6 feet above present ground surface.

\section{CLIMATE AND VEGETATION}

The Shirley Basin area ranges from arid in the lower reaches to semiarid in the higher reaches on the west flank of the Laramie Mountains. There are no official gaging stations, but the average annual precipitation is 12.12 inches at Casper, 14.03 inches at Bates Creek, and 12.97 inches at Medicine Bow. More than half the total precipitation falls during the period April through July. Summers are short; snowstorms may occur as late as June and as early as September. Strong winds are common.

Temperatures are moderate in the summer and severe in the winter. On hot summer days the temperature may reach $90^{\circ} \mathrm{F}$; summer nights are cool. Winter temperatures as low as $-45^{\circ} \mathrm{F}$ have been recorded at mining camps in the Shirley Basin, but periods of severe cold are generally interspersed with periods of moderate temperatures. That the temperature of ground water issuing from springs or being pumped from shallow wells ranges from $43^{\circ}$ to $50^{\circ} \mathrm{F}$, suggests an average annual temperature of about $45^{\circ} \mathrm{F}$ for the Shirley Basin area.

Vegetation is typical of high plains. It consists of sagebrush, squirreltail and other grasses, and pricklypear on flat or gently rolling terrain; piñon pine, scrub fir, juniper, and aspen on the north slopes of the canyons at the edge of Bates Hole; and pine, spruce, fir, and aspen on the west flank of the Laramie Mountains. Deciduous trees, other than aspen, are not prevalent in the area, even along the perennial streams.

\section{EARLY CULTURE}

Tipi rings are numerous in the Shirley Basin and attest to early occupation of the area by nomadic Indians. The observed rings are 10-20 feet in diameter, generally in groups of 10 or more, and of both the simple- and multiple-course types. For the most part, they are on broad spurs or on high bluffs overlooking lower areas where game may have been plentiful at one time. Water is not available now at any of the sites, but there are springs within a few miles of all of them.

Well-preserved rings were observed on two spurs in the $\mathrm{SE} 1 / 4 \mathrm{NW}^{1} / 4$, sec. $23, \mathrm{~T} .27 \mathrm{~N}$., R. $77 \mathrm{~W}$., and less-well-preserved rings are along the erosional bluffs that extend several miles eastward from the SW. cor. sec. $28, T .27$ N., R. 80 W., and from sec. 32 , T. 29 N., R. 77 W. Several of the rings in sec. 23 are shown in figure 4 . The ring in the foreground is about 13 feet in diameter and consists of several courses of sandstone boulders, obtained locally from outcrops of the Cloverly Formation. The boulders are 6-14 inches in maximum dimension. Similar rings can be seen higher on the spur, and other rings extend several hundred feet down the spur from the area shown in the photograph. The rings in this area contain only an isolated rock or two within the circle, but one ring on the south rim contains what appears to be a hearth.

The ring shown on figure 5 , unlike any other seen in the area, consists of many sandstone slabs, most of which are carefully set on end in the ground so that they tilt inward. The ring, 2 feet in thickness and about 8 feet in diameter, is near the sandstone outcrops shown in figure 4 (upper right). The soil inside the ring contains, and is covered by, flint chips and a few broken artifacts.

Artifacts are abundant in the Shirley Basin area, particularly close to sources of flinty materials. On the top of a prominent hill (VABM Holiday) in the SE. cor. sec. 14, T. 27 N., R. 77 W., numerous flinty chips and rejected artifacts are near outcrops of silicified Cloverly sandstone. Near the spring in the NW $1 / 4$ SW $1 / 4$ sec. 12 , T. 28 N., R. 77 W., about 100 feet below a silicified zone at the top of the Madison Limestone, an area of an acre or more contains piles of flint chips and broken or imperfect artifacts. 


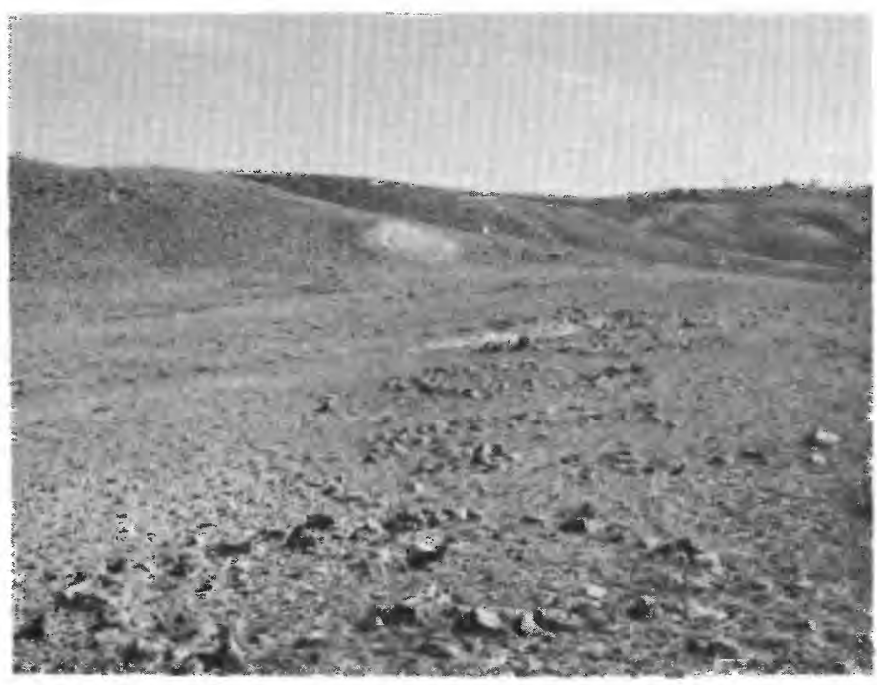

FIGURE 4. - Tipi rings on flat-topped spur in eastern part of the Shirley Basin. Ring in foreground is about 13 feet in diameter.

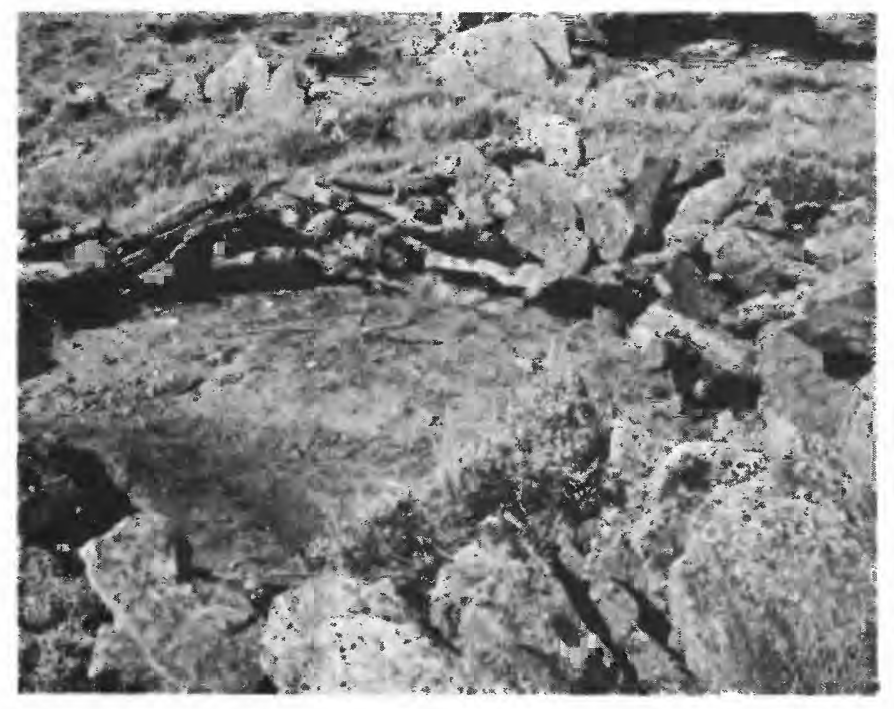

FIGURE 5. - Ring of unknown designation but associated with tipi rings shown in figure 4 . Ring is about 8 feet in diameter, and soil within it contains many flint chips.

\section{PREVIOUS WORK}

The geology and mineral resources of the Laramie Basin, Wyo., were described by Darton and Siebenthal (1909), and their reconnaissance map, at a scale of about 1 inch $=7$ miles, includes four townships in the southeast corner of the area discussed in this report. Although the configuration of their contact between Tertiary and Cretaceous rocks in T. 27 N., R. 78 W., and the $\mathrm{W} 1 / 2$ T. 27 N., R. $77 \mathrm{~W}$., is approximately correct, it is shown about 6 miles north of its proper position and appears to have been misplotted by one township.
The Shirley Basin area was investigated by Konkel (1935), Peterson (1935), Roehler (1958), Riedl (1959), and Shipp (1959) as part of the requirements for advanced degrees at the University of Wyoming. The ore deposits and their origin were discussed by Adler (1964), Bailey (1965), Harshman (1961, 1962, 1966, and 1968a), Melin (1964), and Rosholt, Harshman, Shields, and Garner (1964).

Miscellaneous Geologic Investigations Map I-539 (Harshman, 1968b) shows the 450-square-mile Shirley Basin area discussed in this report and is referred to frequently in the following discussions of the geology and ore deposits of the area.

\section{HISTORY AND FIELDWORK}

Uranium was discovered in the Shirley Basin in 1955 when the Teton Exploration Drilling Co. of Casper, Wyo., found ore-grade material while drilling just west of the Little Medicine Bow River in secs. 2 and 3, T. 27 N., R. 78 W. The discovery attracted only minor attention until the summer of 1957, when several thousand claims were staked in an area of about 150 square miles. Extensive drilling was started immediately, and by the end of 1959 , more than 1 million feet of drilling had been completed. Most holes were drilled through the ore-bearing Wind River Formation and a few tens of feet into the underlying pre-Tertiary rocks. Most holes were probed, and for these, resistivity, gamma-ray, and, for some holes, self-potential logs were prepared. Lithologic logs, based on 5-foot sample intervals, were made by most property owners.

By the spring of 1959 it was evident that the Shirley Basin contained one of the Nation's major reserves of uranium ore, and mining companies made plans to exploit the deposits. Utah Mining Corp. (now Utah Construction and Mining Co.) constructed surface facilities and in the summer of 1959 started to sink a $121 / 2$-foot-inside-diameter concrete-lined circular shaft on their property in sec. 28 , T. 28 N., R. 78 W. Because of heavy inflow of water, the shaft was plugged at a depth of 365 feet, and development work was started at the 330 -foot level. The first Shirley Basin uranium ore was produced in March 1960 from development headings in the Utah Construction and Mining Co. mine.

In July 1960 the Petrotomics Co. began to strip 3 million yards of overburden in preparation for mining large high-grade uranium ore bodies on their property in secs. 4 and 9 , T. 27 N., R. $78 \mathrm{~W}$. The first ore was mined from this property in December 
1960. Ore from the Utah mine was shipped to the Lucky Mc mill in the Gas Hills; ore from the Petrotomics Co. pit was processed outside the area until October 1962 when a mill employing solvent-extraction techniques was completed on the property.

In late 1964, after a 4-year period of research, Utah Construction and Mining Co. abandoned underground mining in favor of in situ leaching of the ore-bearing sandstone with sulfuric acid introduced through drill holes. The uranium in the pregnant solution pumped from the leached area is recovered by ion-exchange techniques.

Ore was discovered by exploratory drilling on other properties in the Shirley Basin, but no new mines were activated until the summer of 1965 when Centennial Development Co. completed a shaft in sec. 26, T. 28 N., R. 78 W., on the Nall Lease of the Homestake Mining Co. Activity on this property was suspended after about 1 year of developmental work and experimental mining.

In October 1966, Petrotomics Co. started a new open pit in sec. 15, T. 27 N., R. 78 W. The first ore from this pit was mined in September 1967 from high-grade ore bodies about 180 feet below the ground surface.

The Shirley Basin project was started in the fall of 1959 after drilling by private individuals and mining companies indicated that the basin contained one of the Nation's largest uranium ore reserves. Advanced copies of topographic maps became available late in the summer of 1960 , and geologic mapping was started in the eastern part of the area. Summer fieldwork continued through 1964 and included regional mapping and studies of uranium deposits in the Utah Construction and Mining Co. underground mine and the Petrotomics Co. Section 9 open pit. Short periods were spent in the field in 1965,1966 , and 1967 in reconnaissance mapping to the east of the area covered in this report and in the continued study of the ore deposits exposed by mining operations.

Concurrent with regional mapping and ore-deposits studies, considerable subsurface data were compiled from drill-hole cuttings and from waterdepth measurements made in several hundred drill holes.

The writer was assisted in the summers of 196062 by J. W. Hasler, Jay Hodges and A. P. Butler, and Robert B. Laughon, respectively.

\section{ACKNOWLEDGMENTS}

The author especially thanks the fine people of the area whose cooperation and friendliness aided in this investigation. Among them are Weston Bourrett, Robert Melin, Robert Bailey, and Jack Bailey of Utah Construction and Mining Co.; Norman Grant, G. K. Coats, Robert Cypert, and Robert Odell of Tidewater Oil Co. and subsequently of Petrotomics Co.; Richard Lisco of the Teton Exploration Drilling Co.; Cotter Ferguson of Gas Hills Uranium Co.; Fred Groth and Dean Webb of Kerr-McGee Corp.; and Page Jenkins, consultant. Dr. Paul McGrew, University of Wyoming, made rapid field identifications of vertebrate-fossil collections. These identifications were valuable as a guide in day-today mapping in the Bates Hole area.

The author is grateful to many Geological Survey colleagues who have contributed to this study by criticism and discussion.

Analytical data essential for the study of the ore deposits and the alteration associated with them were furnished by G. T. Burrow, Ardith J. Bartel, Nancy M. Conklin, E. F. Cooley, E. J. Fennelly, Dorothy Ferguson, I. C. Frost, A. J. Gude, J. C. Hamilton, M. W. Solt, Lorraine Lee, H. H. Lipp, Violet Merritt, Wayne Mountjoy, H. M. Nakagawa, L. E. Patten, L. F. Rader, D. L. Skinner, Barbara Tobin, Roberta Wilkey, and E. J. Young. Samples of ground water were analyzed in the Denver laboratories of the U.S. Geological Survey.

\section{STRATIGRAPHY}

Rocks in the Shirley Basin area are of both igneous and sedimentary origin and range in age from Precambrian to Cenozoic (table 1). Quaternary surficial deposits fill some of the valleys and form terraces related to at least two erosion cycles earlier than the present. The sedimentary rocks, particularly those of Tertiary age, are widespread at the surface and are the host rocks for the uranium deposits. Igneous and metamorphic rocks of Precambrian age and sedimentary rocks of Paleozoic age crop out only in the northeastern part of the area, on the western flank of the Laramie Mountains. Rocks of Mesozoic age crop out in Bates Hole and along the southern border of the area, where erosion has removed the Tertiary rocks.

The Shirley Basin is structurally simple. It is an erosional feature whose position is governed to some extent by a broad syncline in the pre-Tertiary rocks. The synclinal axis trends northwestward, parallel to the erosional axis of the basin, and lies 9-10 miles west of the basin axis. Paleozoic, Mesozoic, and, to a lesser extent, Tertiary rocks have been broken by faults that show small displacements. 
Two faults with displacements of about 100 feet are just west of the project area.

\section{PRECAMBRIAN IGNEOUS AND METAMORPHIC ROCKS}

The principal igneous and metamorphic rocks in the Shirley Basin area are biotite granite, diabase, and granite gneiss, all of Precambrian age. These rocks form the core of the Laramie Mountains, and they are exposed in the northeastern part of the mapped area. Deep drill holes show that similar rocks underlie the Shirley Basin at a depth of as much as 5,000 feet.

The granite ranges in texture from coarse-grained porphyritic to aplitic, but the compositions of the various facies are similar. Most common is a medium- to coarse-grained pink facies composed of quartz, feldspar, and very minor amounts of ferromagnesian minerals, principally biotite. In some places this facies becomes porphyritic and contains feldspar crystals as much as 3 inches long. Less common in the report area are irregular or dikelike bodies of pink or light-gray aplitic granite.

The granite weathers to a coarse sandy soil that forms a thin mantle over the somewhat rounded bedrock surfaces. In most places erosion keeps pace with disintegration, and therefore moderately fresh granite is close to the surface. However, intensely weathered surfaces are found in some places where the granite has recently been exposed by removal of the overlying Paleozoic rocks. The weathered rock is unmistakably related to a pre-Mississippian erosion surface characterized by intense weathering.

Three prominent joint sets that have broken the granite govern the shape of several granite pinnacles in the northeast corner of the mapped area. The most prominent joints are vertical, strike N. $40^{\circ}-$ $50^{\circ} \mathrm{E}$., and give rise to the linearity that is so prominent on aerial photographs of the area. These joints appear to be tension fractures, for some of them are occupied by diabase dikes or quartz veins. Another set of joints is vertical and strikes within a few degrees of north. These joints appear to have been tight at the time of diabase intrusion, although one of them is occupied by a dike about 10 feet wide and 2 miles long. The third, and least conspicuous, set of joints is approximately horizontal and may have been caused by relief of stress following erosion of the upper part of the granite.

Thin sections of the granite contain quartz, potassium-feldspar (microcline and orthoclase), plagioclase, and biotite, listed in decreasing order of abundance. The potassium-feldspars show incipient alteration to kaolin or sericite; the plagioclase, composition about $A b_{80}$, shows moderate alteration. In some thin sections biotite has been completely altered to chlorite, and a part of the plagioclase has been altered to epidote. The feldspars, and to a lesser extent the quartz, contain small amounts of hematite, giving rise to the pink color of the granite.

Diabase dikes, common in the part of the Laramie Mountains included in the mapped area, are easily recognized on aerial photographs (fig. 6). The dikes range in width from a few inches to 300 feet; some have been traced for more than 6 miles. The dikes have been intruded along strong joints that strike about N. $45^{\circ} \mathrm{E}$. and offered easy access toward the surface at the time of emplacement. The dikes are virtually vertical. One diabase dike that trends about N. $15^{\circ} \mathrm{W}$. and dips vertically occupies a fracture that has offset several northeast-trending diabase dikes. No other northerly trending dikes are known in the area.

In flat or gently rolling terrain the diabase dikes may not crop out. They weather more rapidly than granite and generally occupy saddlelike depressions or troughs filled with a greenish-brown fine-grained soil which supports a luxuriant growth of sagebrush, but few conifers. All but the very narrow dikes have indurated the adjacent granite, and differential weathering has given rise to two parallel ridges that define the dike walls.

In hand specimen the dike rock is a greenish-gray ophitic intergrowth of feldspar and a pyroxenelike dark mineral. The rock is extremely tough and appears to be unaltered. In thin section the rock is shown to be a quartz diabase in which the original pyroxene has been completely converted to greenishgray pleochroic hornblende. Quartz occurs as micrographic intergrowths with alkali feldspar and is the latest product of crystallization. The alteration of pyroxene to hornblende is considered to be deuteric. The plagioclase is considerably altered but approximates labradorite in composition.

Metamorphic rocks, common in parts of the core of the Laramie Mountains, are sparse in the mapped area. Several small irregular masses and dikelike bodies of granite gneiss were noted during field mapping in the northeastern part of the Shirley Basin area. These are composed of quartz, potassium feldspar, plagioclase, and a dark mineral, generally biotite. The component minerals are roughly alined. The rock is probably older than the granite, although possibly it represents a slightly metamorphosed part of the granite itself.

Several minor quartz veins are present in the area. One, shown on the geologic map (Harshman, 1968b), 
is offset by a northwest-striking diabase dike and thus is older than the dike. A short distance east of the mapped area, a 5 -foot-wide quartz vein has been emplaced parallel to the north wall of a northeasttrending diabase dike and from a few inches to 30 feet from it. This quartz vein also appears to be younger than the dike. Both veins are bull quartz containing no other visible minerals.

\section{PALEOzoic}

In the Shirley Basin area the oldest sedimentary rocks are limestone, dolomite, sandstone, and quartzite strata of Mississippian, Pennsylvanian, and Permian age. No rocks of Cambrian, Ordovician, Silurian, or Devonian age have been recognized; if deposited in the area, they were subsequently removed by erosion.
Stratigraphic nomenclature for rocks of Paleozoic age on the west flank of the Laramie Mountains has undergone considerable change. Darton (1908) used the name Casper Formation to identify a sequence of sedimentary rocks of Carboniferous age that crop out on the west flank of the Laramie Mountains, overlie the Precambrian granite, and underlie the Satanka Shale (the lower part of the Goose Egg Formation of this report). Knight (1929), Miller and Thomas (1936), Thomas (1948), Thompson and Thomas (1953), Agatston (1954), Maughan and Wilson (1960), Maughan (1963), and others proposed various restrictions on the use of the name Casper. Current usage, followed in this report, restricts the name Casper Formation to the upper part of the stratigraphic interval described by Darton; the lower part is termed the Madison Limestone.

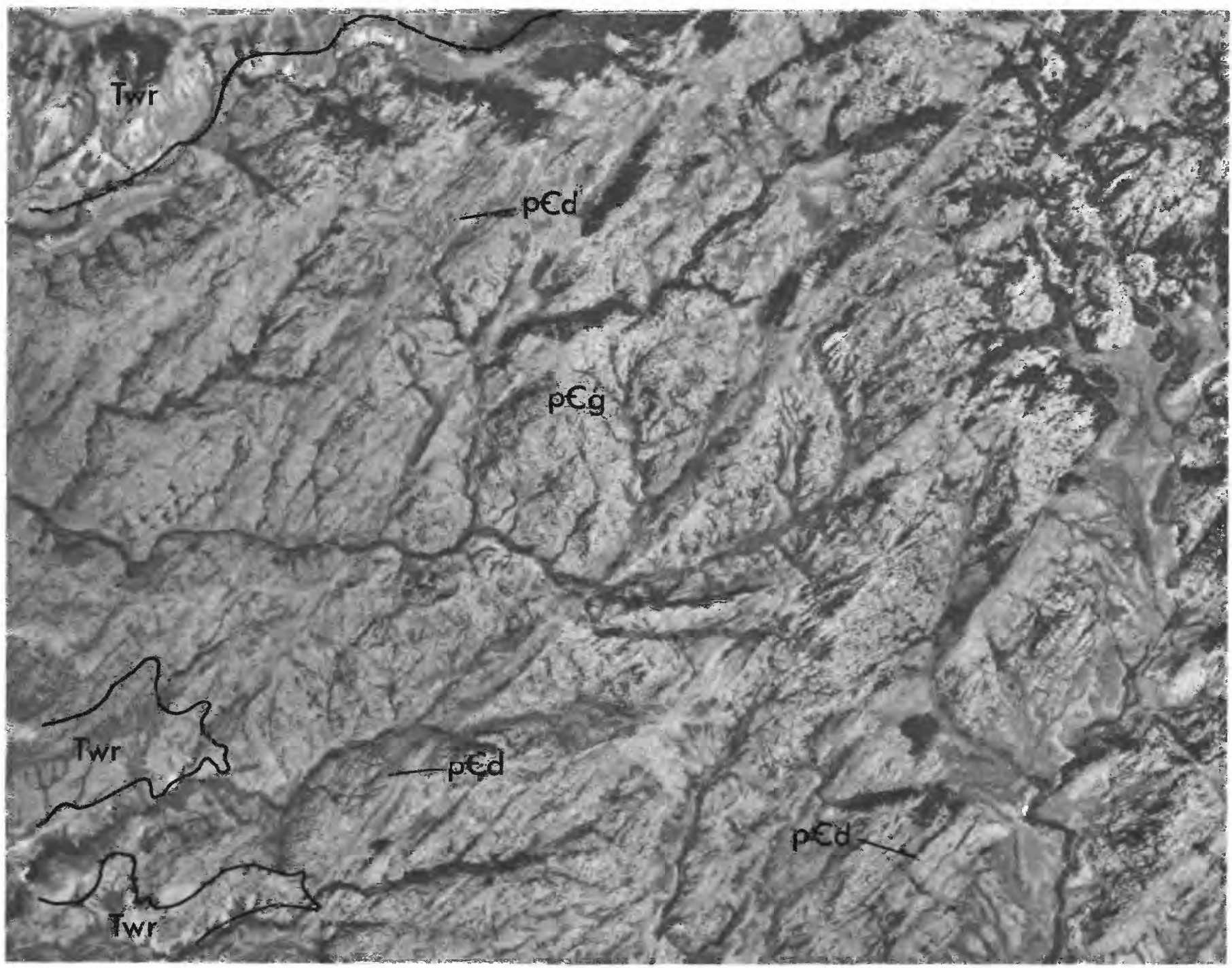

FIgURE 6. - Aerial photograph of diabase dikes ( $€ € d$ ) intruding Precambrian granite ( $p € g$ ) in T. 27 N., Rs. 75-76 W. White River Formation (Twr) laps on granite (at left corners). 
TABLE 1. - Stratigraphic units in the Shirley Basin area

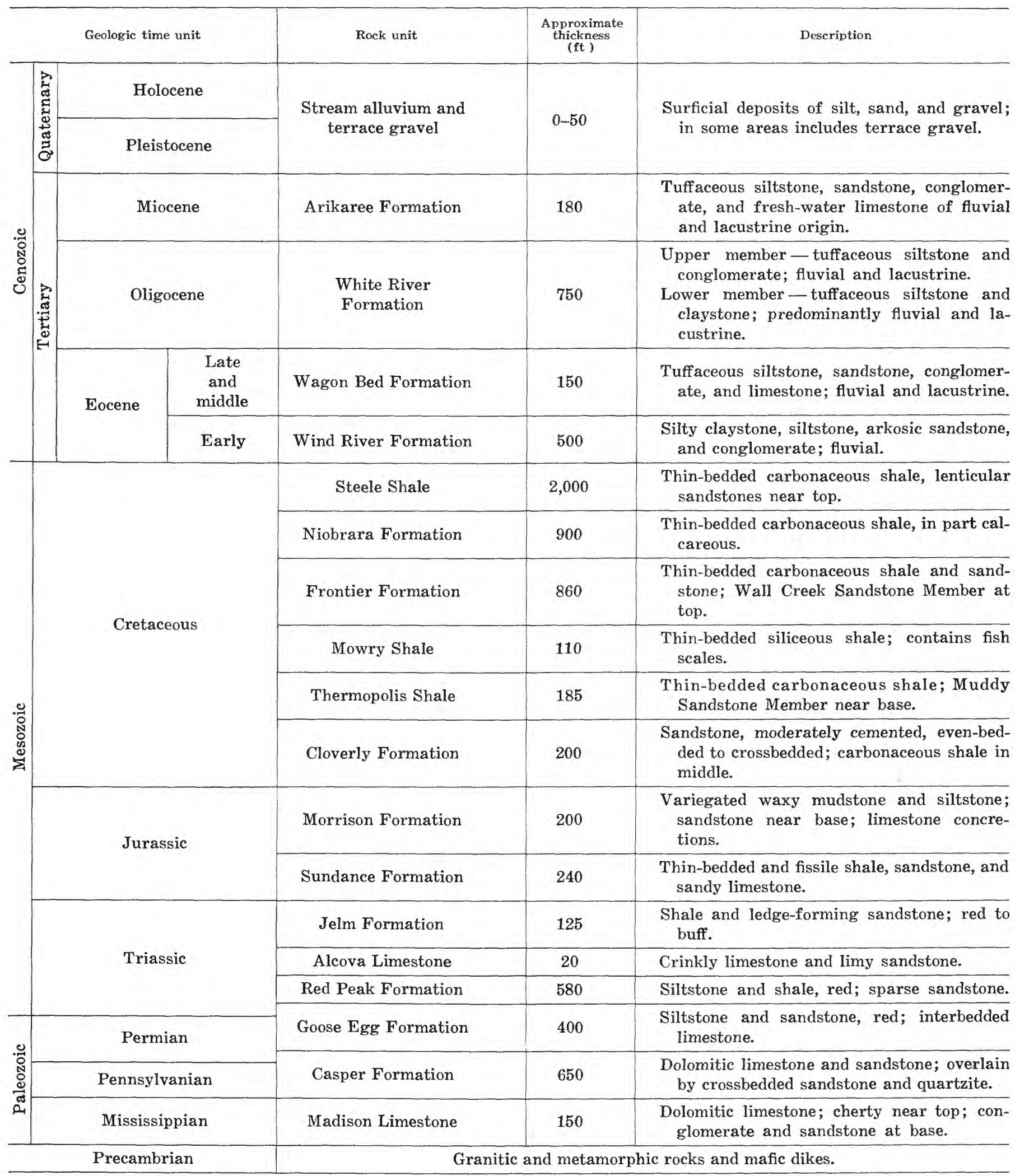


MADISON LIMESTONE

The name Madison Limestone was first used by Peale (1893) to identify a 1,250-foot-thick series of massive, laminated, and siliceous dolomitic limestone beds exposed in the Three Forks area of the Madison Range in southwestern Montana. The formation thins by truncation southward from the type locality and pinches out southeast of the Shirley Basin area. The Madison Limestone is of Mississippian age.

Many divisions of the Madison have been proposed, but none of them are entirely satisfactory for field mapping in the Shirley Basin area. The Madison Limestone was mapped (Harshman, 1968b) as a single unit in the area, but it may be divided into three distinctive lithologic units with a combined thickness of about 150 feet. The basal unit, considered by some geologists to be Cambrian in age but herein considered to be Mississippian as proposed by Maughan (1963), is composed of arkosic sandstone, conglomerate, and quartzite. It ranges in thickness from 10 to 20 feet and was derived, for the most part, from the granitic rock on which it rests. It was deposited on an old weathered remarkably flat erosion surface cut in granitic and metamorphic rocks. Local irregularities in this surface account for variations in thickness. The lower unit is generally dark brown or dark reddish brown and is composed of quartz and feldspar grains and pebbles in a sandy or silty matrix. The coarse fraction is subangular to rounded, and some of the material appears to have been derived from areas close to the place of deposition. Pebbles, where present, are generally in the lower part of the unit, and in most places they grade upward into finer grained material. In some areas this unit is a well-cemented quartzite; in others it is only moderately cemented, and the rock is friable. Crossbeds are common and range from a fraction of an inch to about 15 inches in thickness.

The basal unit resists erosion and characteristically crops out in a nearly vertical low cliff or forms flat dip slopes (fig. 7).

A sequence of thin-bedded pink, purple, and gray dolomitic limestone and dolomite overlies the lower unit. In most places the contact with the underlying sandstone or quartzite is poorly exposed; however, in the exposures examined the contact is rather well defined, grading upward in a few inches from sandstone, through calcareous sandstone and sandy dolomite, to dolomite. The contact appears to be conformable.
Individual beds in the middle unit are 2-6 inches thick and persist laterally. Some beds contain as much as 5 percent coarse sand; others contain almost none. The sandy beds weather to "a rough, pitted surface. In some places the rock contains small vugs filled with calcite or quartz crystals; in other places it contains small veinlets or irregular masses of cherty silica. The middle unit is about $70-90$ feet thick.

The upper unit consists of dolomitic limestone beds, similar to those in the middle unit, interspersed with lenticular masses and persistent beds of chert. The chert is greenish gray to brownish gray, is generally fossiliferous, and occurs as beds that range in thickness from about 1 inch to about 24 inches. The contact between the middle and upper units is indistinct, and in most places the first welldefined chert bed is underlain by $15-20$ feet of strata containing thin beds or small lenticular masses of chert. The upper unit ranges from 50 to about 75 feet in thickness; the variation appears to be due to erosion of the upper part of the upper unit.

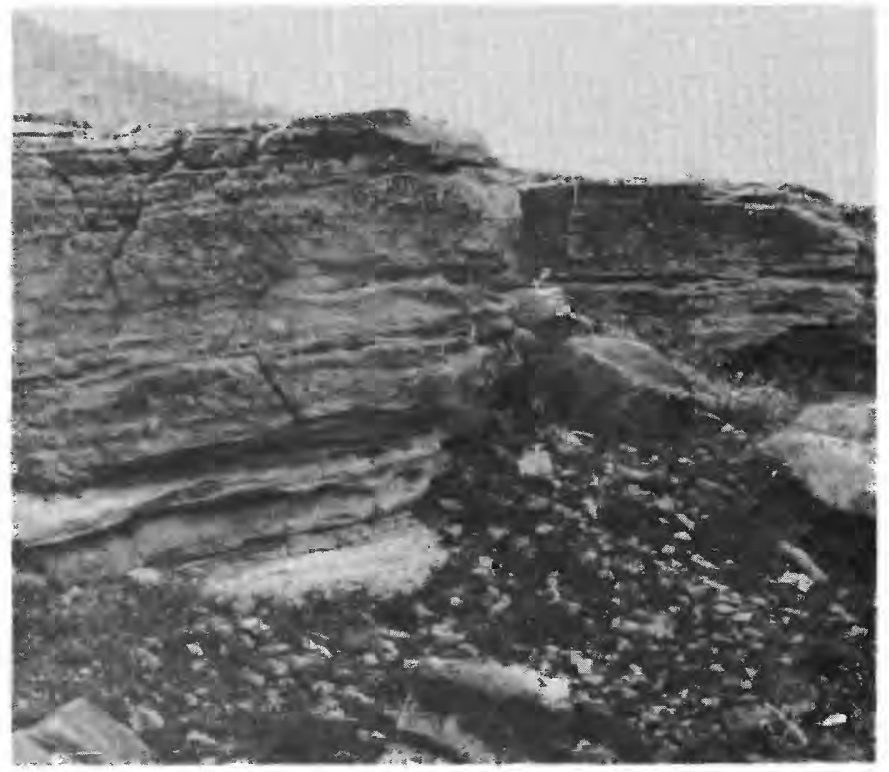

Figure 7. - Outcrop of basal sandstone unit of Madison Limestone in sec. 16, T. 29 N., R. 77 W. Base of exposure rests on Precambrian granite; top is calcareous sandstone in contact with dolomitic limestone unit.

\section{POST-MADISON EROSION}

The top of the Madison Limestone is separated from the base of the Casper Formation by a welldeveloped erosional unconformity. In some places a 
few inches to a few feet of poorly cemented red sand, silt, or sandy silt separates the two formations; in other places, for example one-third mile south of the Taylor Ranch in sec. 2, T. 28 N., R. 77 W., where a well-developed karst topography formed in the top of the Madison Limestone, as much as 20 feet of solution or collapse breccia mixed with red sand and silt separate the two formations (fig. 8). Workings of the Night Owl uranium prospect have explored uranium-bearing apatite associated with chert emplaced along the old karst surface in sec. 12, T. 28 N., R. $77 \mathrm{~W}$. The chert in the uranium deposits is not genetically related to the chert in the upper part of the Madison Limestone.

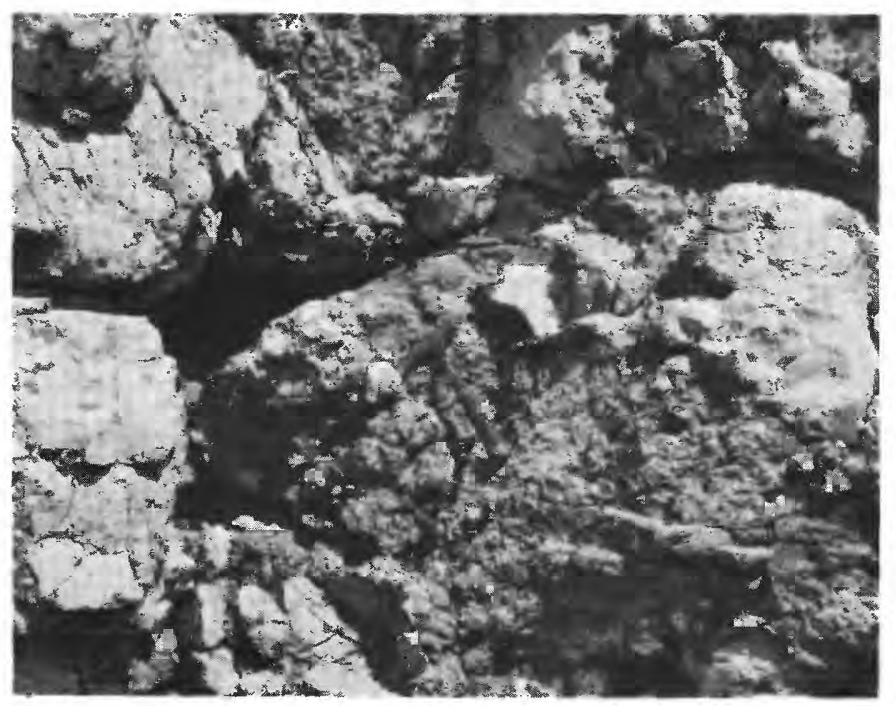

Figure 8. - Solution breccia in well-developed karst surface, $\mathrm{NE}^{1 / 4}$ sec. 2 , T. 28 N., R. 77 W. Light-colored material is brecciated Madison Limestone; dark-colored material is red sand and silt filling voids and caverns.

\section{CASPER FORMATION}

The Casper Formation, as used in this report, consists of all strata overlying the Madison Limestone and underlying the Opeche (lowest) Shale Member of the Goose Egg Formation. The Casper Formation is considered to be Early, Middle, and Late Pennsylvanian and Early Permian in age although the Lower Pennsylvanian strata are absent in the report area. The Casper is similar in lithology to the combined Tensleep Sandstone and Amsden Formation, but Keefer and Van Lieu (1966) considered it to be appreciably younger than these formations.

In the Shirley Basin area the entire thickness of the Casper Formation is not exposed at any one place, and therefore the formation must be described from several partial sections in outcrops slightly more than a mile apart. Because of abrupt lithofacies changes along the strike of individual beds, correlation between the several partial sections may be inexact, and all of the strata described may not be present in any one area.

The Casper Formation in the northeastern part of T. 28 N., R. 77 W., may be divided into two units having a total thickness of about 650 feet. The lower unit is about 300 feet thick and consists of pink, purple, and gray dolomitic limestone and dolomite and $\tan$ to reddish-brown dolomitic sandstone, sandstone, and quartzite. Beds in the carbonate rocks range in thickness from 1 inch to 3 feet and contain considerable siliceous material as irregular chert masses and as dispersed grains of coarse-grained sand. Weathered beds have very rough pitted and gnarled surfaces and form a series of prominent ledges. Laterally there is considerable change in lithology, and some of the dolomite beds grade into dolomitic sandstone or even quartzite within a few hundred feet. The clastic rocks are in beds 1-6 inches thick; generally they are evenly bedded. In most areas they are well-cemented sandstone, but in some places they contain enough silica cement to class them as quartzite. Crossbedded sandstone is present in some areas. From about 110 to 140 feet above the base of the lower unit in secs. 1 and 2 , T. 28 N., R. 77 W., there are two red, crossbedded, and moderately well cemented sandstone beds that have good lateral continuity and have been used in correlating the various partial sections measured in the area. These two sandstone beds, separated by a 6 -foot-thick sequence of thinbedded sandy dolomite, may represent the base of the upper unit of the Casper Formation as used by Agatston (1954). From the top of the red beds to the top of the lower unit the strata consist of principally sandy dolomitic limestone that contains several thin jasper beds 1-6 inches thick as well as chert nodules 1-3 inches in diameter.

The upper unit is about 350 feet thick and consists of sandstone and quartzite which, near the base, are interbedded with minor amounts of dolomite and dolomitic limestone. The clastic rocks are in beds a fraction of an inch to a few feet thick; crossbeds are common in some areas. The arenaceous rocks are fine to medium grained, siliceous, and generally buff, tan, or reddish brown and are moderately well to extremely well cemented. Intense cementation occurs along certain beds in some places, and it cuts across bedding planes in other places. 


\section{PALEOZOIC AND MESOZOIC}

GOOSE EGG FORMATION

The Goose Egg Formation was first described and named by Burk and Thomas (1956) from exposures near the Goose Egg Post Office, 11 miles southwest of Casper in Natrona County, Wyo. Maughan (1964) extended the use of the name into the southeastern part of the State. The formation is of Permian and Triassic age and comprises that part of the red-bed sequence that is interstratified with carbonate- and sulfate-bearing rocks. In southeast Wyoming, Maughan proposed the following members, listed in ascending order: Opeche Shale, Minnekahta Limestone, Glendo Shale, Forelle Limestone, Difficulty Shale, Ervay, Freezeout Shale, and Little Medicine. Only the lowest four members, of Permian age, are exposed in the Shirley Basin; the upper four members, of Permian and Triassic age, are covered either by alluvium or by rocks of Tertiary age.

The best exposures of the Goose Egg Formation are in sec. 15, T. 28 N., R. 77 W. Here the Opeche Shale Member rests on the Casper Formation with no apparent angular discordance. The contact is sharp, and in many places it is marked by carbonate (siderite?)-cemented iron-stained round sandstone concretions $1 / 2-1$ inch in diameter. The Opeche is about 70 feet thick in the area and consists of red siltstone beds less than 2 inches thick interbedded with a few sandy siltstone beds. At about 60 feet above the base of the Opeche is a bed of pink to yellowish-red sandy dolomitic limestone about 2 feet thick.

Beds equivalent to the Minnekahta Limestone Member at the type locality crop out about 70-97 feet above the base of the Goose Egg Formation. In ascending order, they consist of 11 feet of interbedded gray to pink dolomitic limestone, limy sandstone, and red sandy siltstone; 9 feet of purple limy siltstone and red silty sandstone; 3 feet of gray to purple dolomitic limestone containing quartz-lined vugs; and 5 feet of purple limestone grading upward into purple siltstone.

Overlying the Minnekahta are thin-bedded red and reddish-orange siltstone beds about 66 feet thick-the Glendo Shale Member of the Goose Egg Formation. Gray-green spots, characteristic of this shale over much of eastern Wyoming, are present in the exposures.

The Forelle Limestone Member, which overlies the Glendo, is about 21 feet thick and from the base upward consists of $\mathbf{1 2}$ feet of gray thin-bedded crenulated or "crinkly" dolomitic limestone interbedded with limy sandstone, 7 feet of red sandy siltstone and sandstone, and 2 feet of gray crenulated sandy dolomitic limestone. The limestone strata of this member form a broad dip slope; they are the highest beds in the Goose Egg Formation exposed in the Shirley Basin, but electric logs of wells drilled in the area show that the overlying members of the Goose Egg Formation are present in the subsurface. The thickness of the Goose Egg Formation, determined from electric logs, is about 400 feet.

\section{MESOzOIC}

RED PEAK FORMATION

The name Red Peak was first used by Love (1939) to identify a sequence of .red siltstone and finegrained sandstone beds exposed along Red Creek a few miles west of Red Peak, in the southern part of the Absaroka Range in Fremont County, Wyo. Love considered the Red Peak to be a member of the Chugwater Formation of Triassic age. High and Picard (1967) and Pipiringos (1968) raised the name to formational rank. As used in this report, which follows the proposals of Pipiringos, the Red Peak Formation includes all strata in the interval between the underlying Goose Egg Formation and the overlying Alcova Limestone and is Early Triassic in age.

Only the upper part of the Red Peak Formation is exposed in the Shirley Basin area; the rest of the strata are covered either by rocks of Tertiary age or by soil. The exposures in the mapped area are generally obscured by talus blocks of the overlying Alcova Limestone, but about 2 miles northeast of the southeast corner of the area, the exposed strata, from bottom upward, are as follows: 6 feet of brick-red thin-bedded siltstone; 6.6 feet of salmonred thin-bedded calcareous siltstone, bleached to pale green along joints; 1.5 feet of white silty finegrained crossbedded calcareous sandstone containing red and yellow concretions about 1 inch in diameter; and 1.2 feet of white and pale-pink fine-grained thinbedded calcareous sandstone.

Electric logs of wells indicate that several sandy beds are present in the middle and lower parts of the Red Peak Formation in the Shirley Basin area and that the total thickness of the formation approximates 580 feet.

\section{ALCOVA LIMESTONE}

The name Alcova Limestone was used by Lee (1927) for an 8-foot-thick limestone exposed in the red-bed sequence near Alcova, Wyo. He considered 
the Alcova to be a member of the Chugwater Formation. Pipiringos (1968) established the Alcova as a formation in the Chugwater Group, and it is so used in this report.

Most of the Alcova Limestone is covered by rocks of Tertiary age. In the few exposures in the eastern part of the mapped area, the Alcova is about 8-19 feet thick and consists of gray or brownish-gray "crinkly" or contorted slabby limestone. However, in a few places outside the area the lower part of the formation consists of massive sandy limestone beds 1-2 feet thick. The Alcova is a resistant unit in an easily eroded sequence of red beds and generally forms hogbacks and dip slopes. The contacts of the Alcova Limestone with the overlying and underlying formations appear to be conformable.

About 2 miles east of the southeast corner of the mapped area, in the southern part of sec. 4, T. 26 N., R. 76 W., the Alcova Limestone crops out in the steep walls of a small creek. Here the limestone has thinned to about 6 feet, and part of the thicker stratigraphic interval normally composed of limestone contains considerable sandy and silty material. In the next exposure, about one-half mile to the southeast, the Alcova Limestone is absent, and the Jelm rests on the Red Peak Formation.

Although described separately in this report, the Alcova Limestone and the Red Peak Formation are shown as a single unit on the geologic map of the Shirley Basin area (Harshman, 1968b).

\section{JELM FORMATION}

The name Jelm Formation was first used by Knight (1917) to identify a 250-foot-thick sequence of strata exposed near the foot of the east slope of Jelm Mountain in Albany County, Wyo. Previously this sequence had been included in the top part of the Chugwater Formation. In later years, beds in the top of the Jelm were excluded from the formation. Pipiringos (1968) defined the Jelm Formation in south-central Wyoming as including the Upper Triassic rocks that lie above the Alcova Limestone and below the Popo Agie Formation, or below the Sundance Formation in areas where the Popo Agie is absent. He recognized a lower and an upper member, the Red Draw Member and Sips Creek Member, respectively; his usage is followed in this report.

The Jelm Formation is well exposed only in a small rounded knob in sec. 28 , T. 28 N., R. $77 \mathrm{~W}$. The Red Draw Member is about 60 feet thick and comprises a sequence of interbedded brick-red, reddish-brown, or white siltstone, claystone, and sand- stone strata containing some greenish-gray finegrained beds. Some of the beds contain calcareous cement, and some beds are ripple marked. The alternation of hard and soft beds in the lower member gives rise to overhanging ledges. The contact of the Red Draw Member with the underlying Alcova Limestone, which is poorly exposed in the creek at the foot of the hill, appears to be sharp and conformable. Pipiringos (1968) believed that on a regional basis the contact may be disconformable.

The upper part of the hill is composed principally of tan and buff well cemented crossbedded and slabby sandstone, provisionally assigned to the Sips Creek Member. These beds are about 27 feet in total thickness. The conglomerate that separates the Red Draw and Sips Creek Members of the Jelm Formation in many other places in Wyoming (Pipiringos, 1968) could not be seen in this exposure, nor could the zone of chert pebbles that in many places is at the base of the overlying Sundance Formation. Lacking these diagnostic marker beds, it is impossible to definitely identify these strata. Although they are shown as Jelm on the geologic map (Harshman, 1968b), possibly the crossbedded sandstone beds near the top of the hill are basal Sundance indurated by silica leached from the tuffaceous White River Formation that once overlay the area; or possibly the Sips Creek Member of the Jelm is absent in this area, and the entire 27-foot-thick sandstone sequence is abnormally indurated basal sandstone of the Sundance.

Electric logs of wells drilled about 5 miles to the west show that the Jelm in that area is about 125 feet thick.

\section{SUNDANCE FORMATION}

The Sundance Formation was named by Darton (1899) from exposures of shale and thin-bedded sandstone of Late Jurassic age in the Black Hills of South Dakota. Subsequently, the name was applied to rocks of similar lithology and age in eastern and central Wyoming. Lee (1927) noted the similarity between the lowest sandstone beds in the Sundance Formation and the entire Nugget Sandstone of southwestern Wyoming, and Bartram (1930), Imlay (1947), Pipiringos (1948), and others correlated the two sandstone units. Love, Denson, and Botinelly (1949) questioned the correlation and showed that a marked unconformity separates the lowest sandstone beds of the Sundance from the Nugget Sandstone. Pipiringos (1968), in part following Imlay's (1947) nomenclature in the Black Hills, recognized seven members for the Sundance Formation and described in detail the widespread erosion surface, almost 
everywhere characterized by chert pebbles, that separates the Sundance Formation from the underlying rocks.

The Sundance Formation in the eastern part of the Shirley Basin area is about 250 feet thick, as shown by the width of outcrop and by electric logs of wells. The Sundance is poorly exposed on the surface; the best exposures are in sec. 13, T. $27 \mathrm{~N}$., R. 77 W., and sec. 28 , T. 28 N., R. 77 W. Six of the seven members of the Sundance can be identified in sec. 13.

As mentioned in the discussion of the Jelm Formation, the chert pebbles that mark the contact between the Jelm and the overlying Canyon Springs Sandstone Member (lowest member) of the Sundance Formation were not found, and without them the precise position of the contact cannot be determined. As mapped (Harshman, 1968b), the Canyon Springs is about 25 feet thick and comprises a sequence of white to buff fine- to medium-grained crossbedded sandstone beds that contain rounded quartz and chert grains. In the southern part of the area, the sandstone is massive and friable and is similar to the Canyon Springs 10 miles to the south, where the member is about 27 feet thick (G. N. Pipiringos, oral commun., 1967). In sec. 13, T. 27 N., R. $77 \mathrm{~W}$., the sandstone beds are highly indurated and slabby, and are thus atypical. The cementation probably is due to downward migration of silica leached from the White River Formation. The electric log of a drill hole 7 miles to the west shows the Canyon Springs Member to be about 45 feet thick in that area.

The Stockade Beaver Shale Member has not been definitely recognized on the surface in the Shirley Basin, and possibly it is not present in the outcrop area. It is identifiable on the log of a well drilled in sec. 14 , T. 27 N., R. 78 W., and it may crop out in the creek near the SE. cor. sec. 13, T. 27 N., R. 77 W. However, this area was disturbed by considerable faulting, and the greenish-yellow shale and siltstone in this small exposure may be a part of the Pine Butte Member of the Sundance Formation. A 35foot-sequence of greenish-gray shale and siltstone, interbedded with thin sandstone and limestone, exposed in the Freezeout Hills 12 miles southwest of the Shirley Basin, was considered by Pipiringos (1957) to be Stockade Beaver. He now (oral commun., 1969) considers these strata to be part of the Hulett Sandstone Member. On the $\log$ of the well in sec. 14, the Stockade Beaver is about 25 feet thick.

The Hulett Sandstone, Lak, and Pine Butte Members of the Sundance are poorly exposed in sec. 13,
T. 27 N., R. 77 W., and faults and associated dip changes hamper estimation of exposed thicknesses of the separate members. Their combined thickness is estimated to be about 80 feet. In the well drilled in sec. 14,7 miles to the west, the combined thickness is about 78 feet. The Hulett Sandstone Member comprises a sequence of beds of fine- to medium-grained calcareous buff to white sandstone that contains many subrounded to rounded and frosted sand grains and some glauconite. A few beds are ripple marked. The Lak Member is similar to the Hulett in the physical character of the rocks, but has a very distinctive pink or orange-red color, discernible even where moderate soil cover obscures the bedrock. The Pine Butte Member comprises a sequence of buff to white fine- to medium-grained calcareous sandstone strata interbedded with greenish-gray shale. The sandstone is ripple marked, and some beds contain glauconite and fossil trails of crawling organisms.

The Redwater Shale Member is fairly well exposed in the Shirley Basin area, particularly in small gullies that cut the gentle slopes characteristic of this member. It comprises a series of greenishor yellowish-gray thin-bedded shale and siltstone beds containing some interbedded limy sandstone and limestone concretions. The limestone concretions are in the more shaly beds whereas the limy sandstone occurs with the siltstone. At least two limestone strata composed largely of coquina shells are present in the upper part of the Redwater, and belemnites are common in the lower part. The Redwater is about 100 feet thick in the outcrop area and in the well drilled in sec. 14 .

The Windy Hill Sandstone Member of the Sundance Formation is 8-10 feet thick and comprises a sequence of medium-grained thin-bedded oolitic buff to gray sandstone layers which are generally ledge forming and ripple marked. Regional studies by Pipiringos (1968) show that this member rests disconformably on the underlying Redwater Shale Member of the Sundance Formation.

\section{MORRISON FORMATION}

The name Morrison Formation was first used by Eldridge in Emmons, Cross, and Eldridge (1896) to describe a 200-foot-thick sequence of fresh-water marl beds of Late Jurassic age exposed in the vicinity of Denver, Colo.; the type locality is near the town of Morrison. The name is now used for rocks of similar age and lithology in an area extending from Oklahoma and Arizona north to South Dakota and Montana. 
In the Shirley Basin, the Morrison Formation is about 200 feet thick and comprises a sequence of nonmarine clayey siltstone, siltstone, and finegrained sandstone strata. The contacts with the underlying Windy Hill Sandstone Member of the Sundance Formation and with the overlying lower sandstone unit of the Cloverly Formation are conformable.

The formation is poorly exposed or covered by Tertiary rocks. The best exposures are on the steep back slopes of the Cloverly hogbacks in the southeastern part of the mapped area. Here, the lower 20 feet of the Morrison consists of buff slightly calcareous medium-grained sandstone interbedded with buff to yellow siltstone. The sandstone and siltstone are ripple marked; the siltstone contains mud cracks. An upper unit, about 180 feet thick, consists of clayey siltstone which is generally dark gray with a greenish cast but contains a few green, maroon, and red zones. Interbedded with the siltstone are thin lenticular beds of fine-grained limestone, almost lithographic, and thin zones of brown and buff concretions.

The upper few feet of the Morrison Formation, in the few places where not covered with talus from the overlying cliff-forming sandstones of the Cloverly Formation, is in sharp contact with the Cloverly.

\section{CLOVERLY FORMATION}

The Lower Cretaceous Cloverly Formation, first described by Darton (1904) from outcrops in the Bighorn Basin near Cloverly, Wyo., is well exposed in the Shirley Basin area. It is divisible into three major stratigraphic units which, though not shown separately on the geologic map of the area, (Harshman, 1968b), are easily distinguishable on the surface and on subsurface resistivity logs. A complete section of Cloverly is exposed along Spring Creek in the western part of secs. 6 and 7, T. 26 N., R. $76 \mathrm{~W}$., just south of the southeast corner of the mapped area. There the lower unit rests on Morrison siltstone with a sharp conformable contact. It is about 93 feet thick, and its basal part comprises 30 feet of white to buff fine- to medium-grained somewhat friable sandstone having a few conglomerate interbeds containing pebbles as much as 2 inches in diameter. The sand grains are subrounded to rounded, and many are frosted. Some of the sandstone is crossbedded (fig. 9). Chert pebbles are common in the lower 20 feet of the sandstone. Individual beds range in thickness from a few inches to several feet, and bedding is irregular. Although all of this sandstone was mapped as Cloverly, the basal few feet may belong in the underlying Morrison Formation, for similar sandstones are present at the top of the Morrison in areas southwest of the Shirley Basin.

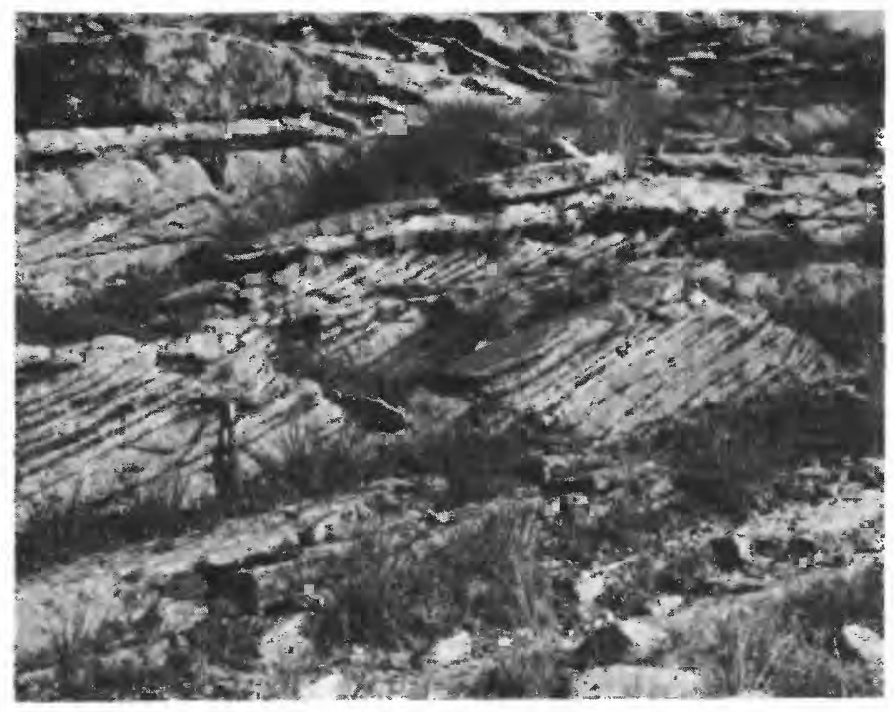

Figure 9. - Crossbedded sandstone near base of. Cloverly Formation, SW $1 / 1 / 1$ sec. 6, T. 26 N., R. 76 W.

Overlying the somewhat friable sandstone is about 45 feet of massive cliff-forming tan sandstone that is medium to fine grained, well cemented, and slightly crossbedded. The sand grains are rounded, some are frosted. The top of the lower sandstone unit comprises a 15- to 20-foot-thick sequence of well-bedded buff quartzose fine- to medium-grained well-cemented sandstone. Some of these sandstone beds grade laterally into carbonaceous shale.

The middle unit is about 20 feet thick and comprises, from the bottom upward, a sequence of fissile dark-gray carbonaceous shale and interbedded silty sandstone; fine-grained crossbedded well-cemented buff sandstone; and dark-gray fissile to blocky shale containing hard indurated claystone beds, thin bentonitic beds, and concretionary ironstone. Mud cracks and ripple marks are common (fig. 10). Changes in thickness of the middle unit occur where the lower shale beds are replaced by sandstone.

The uper unit is about 37 feet thick and consists of fine- to medium-grained white to buff quartzose sandstone in beds that range in thickness from 2 inches to 2 feet.

Resistivity logs from wells drilled in secs. 12 and 14, T. 27 N., R. 78 W., show that the Cloverly in that area has thickened to as much as 200 feet, principally owing to thickening of the sandstone in the lower unit. 


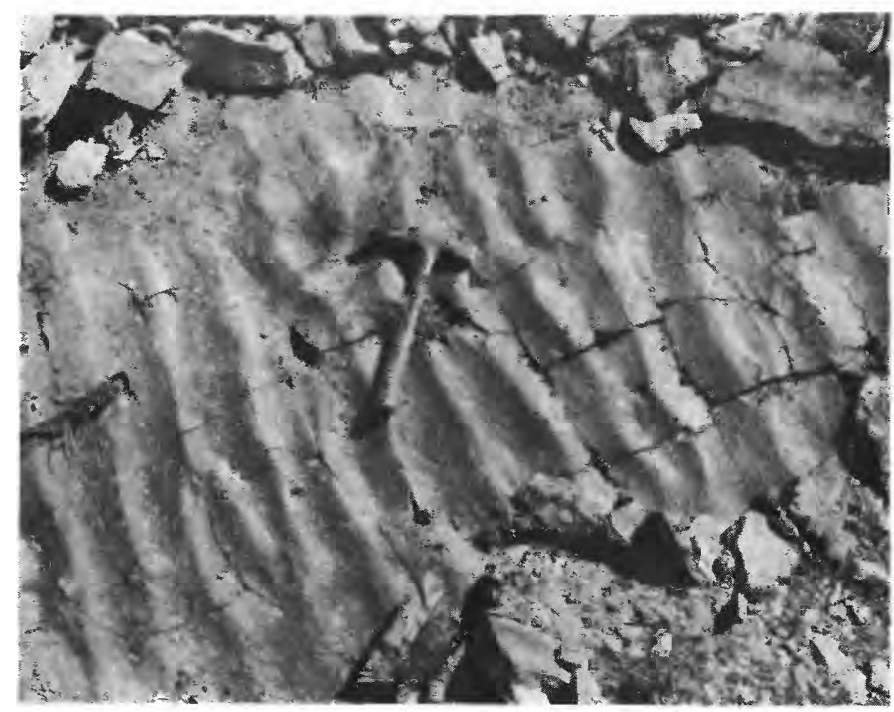

FIGURE 10. - Ripple-marked mudstone characteristic of the upper part of the middle unit of the Cloverly Formation in the Shirley Basin area, NW1/4 sec. 24 , T. 27 N., R. 77 W.

\section{THERMOPOLIS AND MOWRY SHALES}

The Thermopolis and Mowry Shales were not differentiated in the geologic mapping of the Shirley Basin area, although these formations can be recognized on electric logs of wells and in exposures near the Cram Ranch a mile or so south of the southeast corner of the mapped area (Harshman, 1968b). Neither formation is well exposed in the mapped area, and the descriptions that follow are based on the Cram Ranch exposures.

The Thermopolis Shale was named by Lupton (1916) from exposures of shale and sandstone near the town of Thermopolis, Wyo. As then defined, the Thermopolis was considered to be of Late Cretaceous age. It was overlain conformably by the Mowry Shale and underlain conformably by the Cloverly Formation. It is now known to be of Early Cretaceous age. The name "Mowrie beds" was first used by Darton (1904) to describe a sequence of hard light-gray shale and thin-bedded sandstone strata exposed on the east side of the Bighorn Mountains in Johnson County, Wyo. Darton included the Mowrie (now Mowry) beds in the Benton Formation. The Mowry was also considered to be of Late Cretaceous age, but it is now known to be of Early Cretaceous age. The Muddy sand, formerly of drillers' terminology, is considered to be a formal unit, the Muddy Sandstone Member of the Thermopolis Shale (Hintze, 1915).

In the Shirley Basin area the comformable contact between the Cloverly Formation and the overlying
Thermopolis Shale is marked by a 3-foot-thick zone of gradation from ripple-marked fine-grained buff sandstone through shaly thin-bedded gray finegrained sandstone to black fissile shale. That part of the Thermopolis that underlies the Muddy Sandstone Member comprises dark-gray to black fissile carbonaceous shale of marine origin. It is about 60 feet thick in the Cram Ranch area, and 19 feet above the base it contains a 2-foot-thick bed of radiating acicular aragonite crystals. The Thermopolis Shale underlying the Muddy Sandstone Member in a well in sec. 14, T. 27 N., R. 78 W., is about 55 feet thick.

The black fissile Thermospolis Shale is overlain by a 6-foot-thick zone of silty thin-bedded sandstone that weathers gray to buff and an 8-foot-thick irregularly bedded medium- to fine-grained buff to light-gray silty sandstone - the Muddy Sandstone Member of the Thermopolis Shale. Individual beds range in thickness from a fraction of an inch to 6 inches, are well indurated, and generally form ledges. Some exposures contain ripple marks.

Overlying this sandstone are brownish-gray thinbedded fine-grained silty sandstone beds interbedded with thin-bedded siltstone and shale. The siltstone contains some carbon flecks and a few pyrite crystals. The rocks in this interval, which is approximately 50 feet thick, are poorly indurated, underlie low flat areas, and have few outcrops. At the top of this sequence is a 2-foot-thick bed of silty lignite associated with several thin limy sandstone beds that contain mud cracks and what look like root tubes. This 50 -foot-thick sequence of beds appears to be of paludal origin and is considered to be part of the Thermopolis Shale, although some of the sandy beds near the base of the sequence may be properly included in the Muddy Sandstone Member.

Overlying the lignite is a transitional zone, about 60 feet thick, comprising sandy siltstone and silty shale interbedded with typical dense siliceous Mowry Shale. In this zone the amount of siltstone and silty shale decreases upward. These strata are arbitrarily included in the upper part of the Thermopolis, and thus the total thickness of the Muddy Sandstone Member and the upper part of the Thermopolis Shale is about 125 feet.

The Mowry Shale is about 110 feet thick in the Shirley Basin area. It is a gray dense siliceous laminated shale which contains abundant marine fish scales and is interbedded with bentonite beds as much as 2-3 feet thick, some of which retain a shaly structure. Associated with some of the bentonite are shale beds as thick as 6 inches that contain considerable calcium carbonate. 
The Mowry Shale is resistant to erosion and generally forms long narrow ridges which weather yellow or off-white and are contorted by surface creep or incipient landsliding. Large blocks of Mowry Shale, their slide planes lubricated by bentonite, slid as much as one-half mile on the steep pre-Wind River erosion surface. They are now partly buried by Tertiary clastic rocks.

\section{FRONTIER FORMATION}

The Frontier Formation, a name used by Knight (1902) for rocks exposed in southwestern Wyoming near the town of Frontier, comprises a sequence of dark-gray carbonaceous shale, silty shale, and sandstone strata underlain by the Mowry Shale and overlain by the Niobrara Formation. It is Late Cretaceous in age.

Exposures of the Frontier are poor in the Shirley Basin area, for the soft nature of the formation gives rise to a rolling grass-covered terrain. The hard siliceous Mowry Shale crops out in prominent ridges, and where these ridges are cut by small gullies the lower few feet of the Frontier is exposed in sharp contact with the Mowry Shale. In some areas the basal 5 feet of the formation consists of reddish- or purplish-gray siltstone and sandy siltstone, in part concretionary, and containing considerable siderite or hematite. The beds are 1-2 inches thick. In other areas the ironstone is not present, and the basal part of the Frontier consists of gray thinbedded silty sandstone and shale. Generally within 5-10 feet above the base of the formation the typical dark-gray thin-bedded shale predominates.

Data from electric logs of wells drilled in the area and from the few poor exposures along ridges and gullies indicate that the lower part of the Frontier Formation is principally dark-gray carbonaceous thin-bedded shale and that the upper part is similar shale interbedded with gray to brownish-gray fineto medium-grained thin-bedded sandstone.

At the top of the Frontier Formation is a series of fine- to medium-grained sandstone beds that weather buff to greenish gray and are interbedded with dark-gray shale. These beds constitute the Wall Creek Sandstone Member of the Frontier Formation. The sandstone beds near the top of the Wall Creek Member crop out in a tributary of Slate Draw in sec. 32 , T. 27 N., R. $77 \mathrm{~W}$. At this place they are medium to coarse grained, siliceous, greenish brown, and slabby to crossbedded and contain considerable biotite and an occasional glauconite grain. The sandstone is cemented by calcium carbonate, silt, and clay. These beds are resistant to erosion and gen- erally form a conspicuous ridge both on the present surface and on the surface now buried by Tertiary rocks. Although sandstone blocks cover the ground surface, outcrops along the ridge are poor. Electric logs of wells drilled in the area show the Wall Creek Member to be about 110 feet thick. Data from the width of outcrop, the dip of the beds, and electric $\operatorname{logs}$ of wells indicate a total thickness of 860 feet for the Frontier Formation.

\section{NIOBRARA FORMATION}

The name Niobrara Formation was first used by Meek and Hayden (1862, p. 418-423) to identify a sequence of limy shale strata exposed along the Missouri River near the mouth of the Niobrara River in Knox County, Nebr. The formation is of Late Cretaceous age.

In the Shirley Basin area the Niobrara Formation crops out only in the SW. cor. T. 27 N., R. 77 W., where erosion has stripped the cover of Tertiary rocks. The formation weathers readily and is poorly exposed in isolated spots along Slate Draw and the Little Medicine Bow River. The contact of the Niobrara and the underlying Wall Creek Sandstone Member of the Frontier Shale is not exposed, but in Slate Draw, about 150 feet downstream from the approximate position of the contact (equivalent to about $10 \mathrm{ft}$ stratigraphically above the base of the formation), the Niobrara consists of dark-gray thinbedded noncalcareous clay shale, some of which is fissile. About 500 feet downstream from the contact, the Niobrara contains some thin limy sandstone beds intercalated in the thin shale beds. About 1,500 feet downstream (120 ft stratigraphically above the base of the formation), typical thin-bedded to fissile silvery-gray calcareous spotted shale beds are exposed.

Cuttings from exploratory drill holes indicate that the upper part of the Niobrara Formation consists principally of black calcareous shale, in some places tending to be fissile and exhibiting the small white spots characteristic of the so-called spotted shale. However, some of the upper shale seems to be noncalcareous. The contact between the Niobrara Formation and the overlying Steele Shale is not exposed in the mapped area, but data from electric logs of wells indicate that the Niobrara Formation in the Shirley Basin area is about 900 feet thick.

\section{STEELE SHALE}

The Steele Shale, named by Darton, Blackwelder, and Siebenthal (1910) from exposures along the 
North Platte River near Fort Steele in Carbon County, Wyo., underlies most of Bates Hole, and it crops out along the southwest edge of the mapped area. The Steele may be divided into a lower part that consists principally of thin-bedded to fissile dark-gray clay shale having minor amounts of lenticular sandstone and dark-brown concretionary sandy ironstone and an upper part in which a considerable amount of lenticular sandstone is interbedded with the shale. The upper, sandstonebearing part is exposed only along the south edge of the mapped area, near the synclinal axis, where the cover of rocks of Tertiary age has been removed by erosion. The sandstone is light gray, tan weathering, poorly sorted, siliceous, medium grained, and calcite cemented. Many of the sandstone beds contain invertebrate fossils; it was from a sandstone ledge in the NW1/4.SE $1 / 4 \mathrm{SW} 1 / 4$ sec. $35, \mathrm{~T} .27 \mathrm{~N}$., R. $79 \mathrm{~W}$., that the Late Cretaceous ammonite Hoplitoplacenticeras was taken (Cobban, 1963). This is the only known record of this genus in the Western Interior of the United States.

The Steele Shale is very soft and easily eroded. It is generally covered with a soft puffy soil mantle which obscures the character and attitude of the underlying rock. Landslides ranging from small to very large are common in this incompetent shale.

Cretaceous formations younger than the Steele Shale have not been recognized in the Shirley Basin area, and if they were ever present in the region, they have been removed by erosion. The maximum remaining thickness of Steele Shale is probably in the general area of the syncline shown on the geologic map (Harshman, 1968b) ; there it may range from 1,500 to 2,000 feet.

\section{CENOzOIC}

\section{FORT UNION (‡) FORMATION}

Rocks of Paleocene age have not been identified in the Shirley Basin, but they may be present in the southern part of the mapped area. A sequence of varicolored soft sandy siltstones, in part carbonaceous, is exposed in a landslide block at the south edge of the area in secs. 4 and 5, T. 26 N., R. 79 W. Similar sandy siltstones were noted in drill cuttings from an exploratory hole about 3 miles to the east in sec. 36, T. 27 N., R. $79 \mathrm{~W}$. In both places the varicolored rocks fill channels eroded in Steele Shale and are overlain by Wind River rocks of contrasting physical appearance. The rocks do not contain ancient pollen, and no other fossils have been found in them. Studies of the meager heavy minerals from three samples were inconclusive but do not rule out the possibility that these rocks are remnants of the Fort Union Formation deposited in stream channels and protected from the extensive erosion that preceded deposition of the Wind River Formation. The maximum thickness of these rocks is about 50 feet.

\section{WIND RIVER FORMATION}

The terms "Wind River deposits" and "Wind River group" were first used by Meek and Hayden (1862, p. 433,447$)$ to identify a series of beds of continental origin exposed in the Wind River Basin and to the west of the Wind River Range. These beds were provisionally placed above the "Fort Union" or "Great Lignite Group" and below the "White River group." St. John (1883, p. 228) first used the term "Wind River formation," and Sinclair and Granger (1911, p. 104-105) divided the formation into the Lysite (lower) and Lost Cabin (upper) Members, lithologically and faunally distinct units in the northeastern part of the Wind River Basin.

The Wind River sediments were deposited in a basinlike depression eroded in rocks of Paleozoic and Mesozoic age. The position of the depression was controlled to some extent by the position of a synclinal axis about 10 miles west of and approximately parallel to the axis of the depression.

The pre-Wind River basin had considerable relief and was drained by a well-developed system of major and tributary streams. The trunk stream, probably a tributary of the ancestral North Platte River, drained northwestward through the basin along a line extending from the northeastern part of $\mathrm{T}$. 26 N., R. $78 \mathrm{~W}$., through the center of T. $27 \mathrm{~N}$., R. $78 \mathrm{~W}$., and the southwestern part of T. $28 \mathrm{~N}$., R. $78 \mathrm{~W}$., to the northeastern part of T. $28 \mathrm{~N}$., R. $79 \mathrm{~W}$. Major tributaries originated far to the west on the flank of the newly formed Granite Mountains and to the east on the flank of the young Laramie Mountains. Locally, relief on the old surface was as much as 300 feet in a lateral distance of about onefourth mile, and over broad areas relief was as much as 1,500 feet in 12 miles.

The erosion surface is probably of Laramide age, but the age cannot be precisely determined from data gathered during this investigation. The surface was cut in rocks as old as Late Cretaceous (Steele Shale), and it is buried beneath rocks as young as early Eocene (Wind River). Although the basin configuration was probably established before deposition of the Wind River Formation, erosion on the basin flanks took place concurrently with deposition on the basin floor. Thus, the. old erosion 
surface becomes progressively younger with increasing height on the basin flanks. The term "preWind River erosion surface" is used, however, for the sake of brevity and because post-Wind River erosion probably caused only a slight modification of the pre-Wind River erosion surface.

Abrupt changes in lithology and thickness are characteristic of the Wind River Formation in the Shirley Basin. The thickest section is along a northwesterly trending zone in the central part of the basin where 450-550 feet of siltstone and sandstone overlies a major valley on the pre-Wind River erosion surface. In and near this zone the Wind River Formation consists of interbedded fine- and coarsegrained rocks, in about equal amounts, interbedded with considerable lignitic material. Westward the formation thins, as the old erosion surface rises, and the proportion of coarse clastic debris increases as the source of the sediment is approached. Eastward the formation thins rapidly as it laps on the steep flank of the Laramie Mountains. Lithologic data, though scanty, suggest that the Wind River does not coarsen as it laps eastward on the older rocks.

In the Shirley Basin the Wind River Formation is widespread and has great economic importance. It underlies or crops out in about two-thirds of the mapped area and it is the host for the uranium ore deposits. The Lysite and Lost Cabin Members of the Wind River Formation cannot be recognized lithologically in the Shirley Basin area, nor can they be distinguished on the basis of the fossil vertebrates and plants collected during this investigation.

The Wind River Formation crops out over most of the south half of the area investigated, but exposures are generally poor owing to the friable nature of the rocks, the low-rolling topography, and the sand and soil at the surface. Fair natural exposures are present along the south edge of the basin, where the lower part of the Wind River crops out in an erosional escarpment locally known as the "south rim." Fair natural exposures also occur along the south edge of Bates Hole, in the west-central part of the area, where Stinking Creek has exposed and eroded the Tertiary rocks in the steep walls of the hole. Two mine pits, one in sec. 9 and the other in sec. 15, T. 27 N., R. 78 W., expose a considerable part of the Wind River Formation in the central part of the Shirley Basin. The general character of the rocks throughout the basin can be determined from cuttings and resistivity logs of exploratory drill holes.

In the southwestern part of the area, along the south rim, the lower part of the Wind River Formation consists principally of a gray boulder conglom- erate and coarse arkosic sandstone that weathers buff to rusty yellow. Drill cuttings indicate that a few silty interbeds, generally greenish gray and rarely purplish red, are present in areas a few miles north of the south rim. There is little or no cement in the coarse clastic debris, and it might properly be called sand, gravel, and boulders. The silty rocks have some clay binder, but they are not indurated; they have been compacted by the weight of the rocks which once overlay the area.

The gravel, cobbles, and boulders in the conglomerate are well rounded, and boulders are as much as 7 feet in diameter, although those more than 3 feet in diameter are rare. The large boulders are Precambrian granite; the smaller ones are granite or Paleozoic and Mesozoic quartzite, chert, sandstone, limestone, siliceous shale, or other types of indurated rock that in early Eocene time flanked the granite cores of the mountain ranges. A few small boulders of Precambrian diabase are also in the conglomerate, but without exception they are intensely weathered and disintegrate with the slightest blow of a hammer.

At the west edge of the mapped area, and for about 10 miles eastward along the south rim, the conglomerate is at or very close to the base of the Wind River Formation. Where not at the base, the conglomerate overlies silty material that fills small stream channels on the pre-Wind River erosion surface. Farther to the east the lower part of the Wind River Formation laps on the flank of the basin, and an increasingly thick wedge of silty shale separates the conglomerate from the base of the Wind River Formation.

At the south edge of Bates Hole, particularly along State Highway 487, outcrops are principally in a coarse-grained sandy facies of the Wind River Formation. A basal conglomerate, of well-rounded gravel and boulders as much as 3 feet in diameter composed of granite and of indurated rocks of Paleozoic and Mesozoic age, rests on the eroded surface of the Steele Shale. The conglomerate is 515 feet thick in the outcrops examined. In most places the conglomerate is overlain by $100-200$ feet of sandstone and some interbedded conglomerate, but in a few places considerable siltstone is present in this lower interval. The upper 100-200 feet of the Wind River Formation in this area contains considerable clayey siltstone, generally in beds 5-20 feet thick intercalated with sandstone. Most of the siltstone is greenish gray, but toward the top of the sequence some is reddish brown or light red.

The Wind River Formation has a maximum thickness of about 425 feet at the south end of Bates Hole. Northward it maintains its lithologic char- 
acter, but it thins as it laps on a ridge on the preTertiary erosion surface. The minimum thickness on the east side of Bates Hole is probably about 15 feet, in sec. 27, T. 29 N., R. 80 W., where the formation is almost totally obscured by extensive landslide blocks of the overlying White River siltstone. On the west side of Bates Hole, in sec. 3, T. 28 N., R. 81 W., west of the mapped area, the Wind River Formation thins in a similar manner.

On the flat-topped ridge just north of Lawn Creek, sec. 8 , T. 29 N., R. 80 W., the Wind River basal conglomerate contains granite boulders as much as 26 feet in greatest dimension (fig. 11). They are exposed along the edge of the ridge for about 1 mile and were apparently deposited on, and slightly above, a pre-Wind River erosion surface that now has a northeasterly dip of about 15 feet per mile. The dip of this surface was probably not much greater at the time of deposition of the boulders.

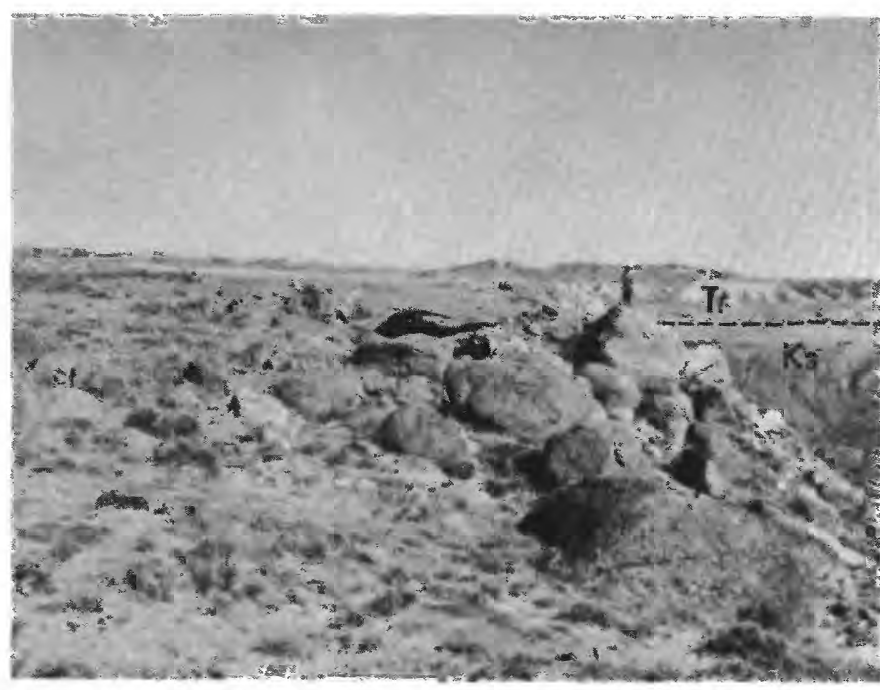

FiguRE 11. - Large granite boulders in basal conglomerate of Wind River Formation, overlying Steele Shale, in Bates Hole, sec. 8, T. 29 N., R. 80 W. The nearly flat erosion surface on Steele Shale (Ks) is overlain by rocks of Tertiary (Tr) age (right center).

About 2 miles to the west, in secs. 11 and 12, T. 29 N., R. 81 W., similar boulders are found in the basal conglomerate of the Wind River Formation. Between the two localities the Wind River Formation has been eroded, but it is assumed that at one time the boulders extended continuously for at least 3 miles, perhaps much more. The boulder outcrop pattern is sinuous and about 300 feet wide. The nearest granitic sources are now about 10 miles to the northeast and 14 miles to the southwest; they were at least that distant in early Eocene time when the boulders were transported and deposited. The boulders were apparently carried by streams flowing eastward from the Granite Mountains; however, their size and their distance from the source are difficult to reconcile with the low stream gradients believed to have been extant at the time of their deposition. There is no evidence that they were carried in mudflows.

The best exposures of the Wind River Formation in the Shirley Basin area are in the Petrotomics Co. open pits, one in sec. 9 , and the other in sec. 15, T. 27 N., R. 78 W. The Section 9 pit exposes about 160 feet of strata in the upper part of the formation, in an interval from about 100 feet to about 260 feet below the reconstructed Wind River-White River contact. A measured section of this exposure follows :

Measured section, north wall, phase 2,1 Petrotomics Co. Section 9 pit

Top of exposure.

Feet

Wind River Formation:

1. Clayey siltstone, buff to yellow, light-brown, olive-green

2. Clayey siltstone, dark-brown, yellow, lignitic, gypsiferous; a few thin sandy gray interbeds 4.9

3. Sandstone, fine- to medium-grained, poorly cemented, buff; a few thin lignitic clay interbeds

4. Clayey siltstone, yellowish-green to bluish-gray; a few thin gypsiferous beds and lignitic beds.... 13.8

5. Clayey siltstone, greenish- and bluish-gray.......... 10.7

6. Sandstone, medium-grained, poorly cemented, yellow; trace of carbon

7. Clayey siltstone, gray-green; trace of carbon........ 19.9

8. Siltstone, yellowish-green...................................... 5.6

9. Silty claystone and siltstone, gray and dark-green

10. Claystone, red, blocky ..................................... 1.3

11. Silty claystone, gray-green................................ 2.4

12. Silty claystone, reddish-purple to yellowish-

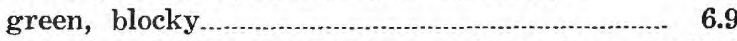

13. Siltstone and silty claystone, greenish-gray.......... 25.4

14. Silty claystone, red, orange .................................... 2.7

15. Sandy siltstone, gray, pyritic; slight $\mathrm{CaCO}_{3}$ cement.

16. Sandstone, unaltered, gray, pyritic, mediumto very coarse-grained; in part crossbedded; compacted but uncemented. Carbonaceous material chiefly on cross beds. This is the upper ore-bearing sandstone. 30.0

Total measured Wind River Formation........ $\overline{162.8}$ Bottom of exposure.

"The pit was excavated in 10 separate units termed "phases."

The Petrotomics Co. Section 15 pit exposes about 185 feet of strata in the interval about 200-385 feet below the top of the Wind River Formation. A composite section on the west wall of this exposure follows: 
Measured section, west wall, Petrotomics Co. Section 15 pit

Top of exposure.

Wind River Formation:

1. Topsoil, brown, sandy.

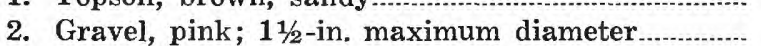

3. Sandstone, very coarse grained, poorly cemented, greenish-yellow.

4. Claystone, silty, yellowish-green; contains lenses of poorly cemented very coarse grained sandstone

5. Sandstone, siliceous, poorly cemented, yellow; gravel as much as 3 in. in diameter.

6. Silty claystone, green; interbedded with brown lenticular lignite beds.

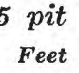

Sandstone, very coarse grained, crossbedded, yellow to buff; some gravel as much as 1 in. in diameter; channels cut in upper part

8. Clayey siltstone, dense, blocky, gray-green.

9. Lignite, silty, dark-gray.

10. Claystone, silty, blocky, green; sandy in lower third

11. Sandstone, medium- to very coarse-grained, silty, crossbedded, gray; calcite cement in top beds. 10.5

12. Lignite, silty, dark-gray 1.5

13. Claystone, silty, blocky, green; sandy in some beds. 21.0

14. Sandstone, very coarse grained, poorly cemented, crossbedded, gray. 10.5

15. Lignite, silty, dark-gray 1.0

16. Siltstone, clayey, greenish-gray; interbedded in lower half with fine-grained gray sandstone

17. Sandstone, very coarse grained, crossbedded, pyritic, carbonaceous, uncemented, gray. This is the lower ore-bearing sandstone.

Total measured Wind River Formation. Bottom of pit.

Both pits are in a belt that overlies the lowest part of the pre-Wind River erosion surface, an area that apparently remained topographically low as the basin gradually filled with Wind River sediments. In periods of low water, sand and silt were deposited in the area in stream channels and as overbank deposits, and decaying vegetation accumulated in transitory swamps. In periods of high water, large channels were cut in the newly deposited sediment, later to be filled with crossbedded sand and gravel. Figures 12, 13, and 14 show the general character of this material after compaction and slight lithification.

The sandstone in this part of the basin is poorly sorted and medium to very coarse grained and is composed principally of quartz and potassium feldspar (orthoclase and microcline) in about equal amounts. It contains an average of about 2.5 percent by weight of heavy minerals and a few percent clay, principally montmorillonite and kaolinite.

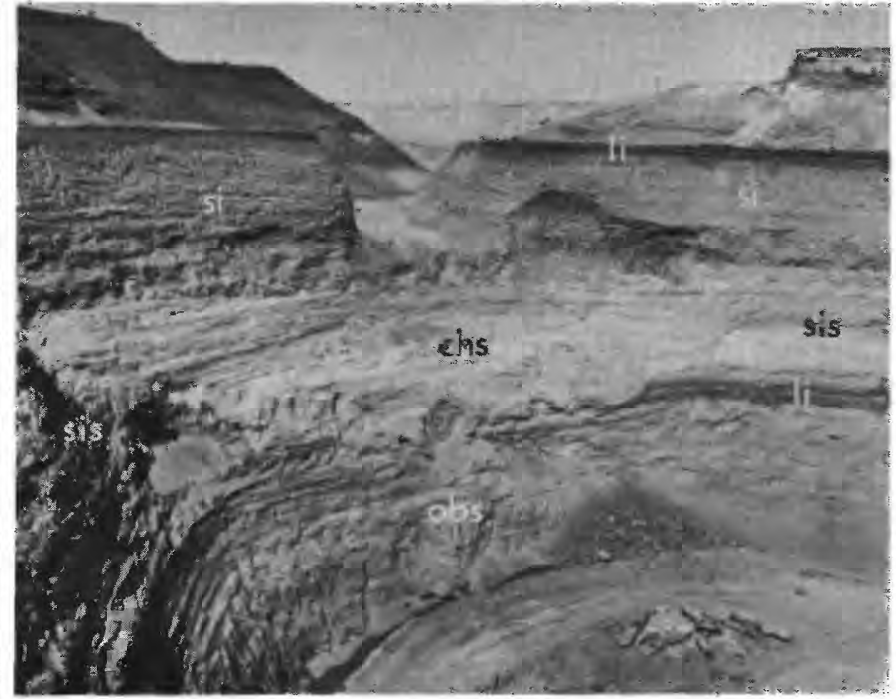

Figure 12. - Southeast wall, phase 7, Petrotomics Co. Section 9 pit, showing: lignite (li) and siltstone (si) in upper part of wall, large sand-filled channel (chs) cut in silty sandstone (sis) and lignite (li), and altered ore-bearing sandstone (obs) of Wind River Formation in lower part of pit (NE1/4 sec. 9, T. 27 N., R. 78 W.).

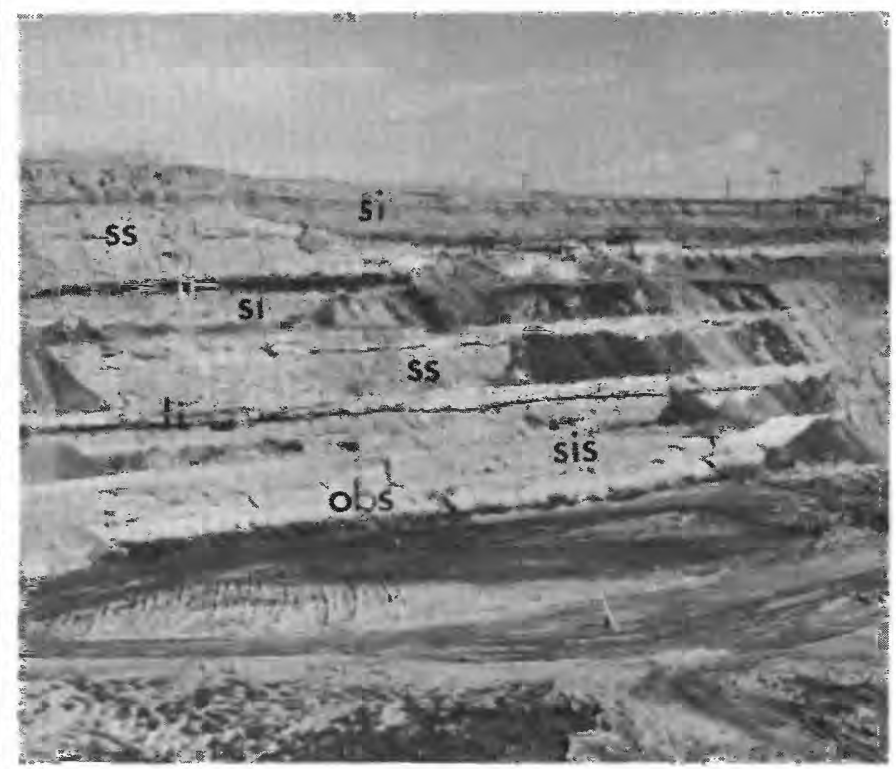

Figure 13. - Northwest wall, Petrotomics Co. Section 15 pit, showing lignite (li), siltstone (si), silty sandstone (sis), sandstone (ss), and ore-bearing sandstone (obs) of Wind River Formation (NE $1 / 4$ sec. 15, T. 27 N., R. 78 W.).

About 100 feet of strata which once overlay the exposures in the Section 9 pit is exposed in small gullies and bluffs in secs. 3 and 4, T. 27 N., R. 78 W., north of the pit, and on the west side of the Petrified Forest area in secs. 11, 12, 13, and 14, east of the pit. North of the pit the rocks are predominantly silty shale, interbedded with minor amounts of sandstone 
and, near the top of the formation, siliceous pebble conglomerate. Generally the siltstone contains considerable lignite and the petrified trunks of trees as much as 3 feet in diameter. The lignitic material weathers to a dark reddish brown with orange and purple tones, a color characteristic of this interval. The strata in the Petrified Forest area are somewhat sandier than those in secs. 3 and 4 but are characterized by the same strong colors, lignitic siltstone, and petrified trees.

Data from exploratory drilling in and near the Section 15 pit show that the interval of Wind River Formation between the bottom of the pit and the underlying Niobrara Formation comprises sandstone, conglomerate, and very minor amounts of shaly siltstone.

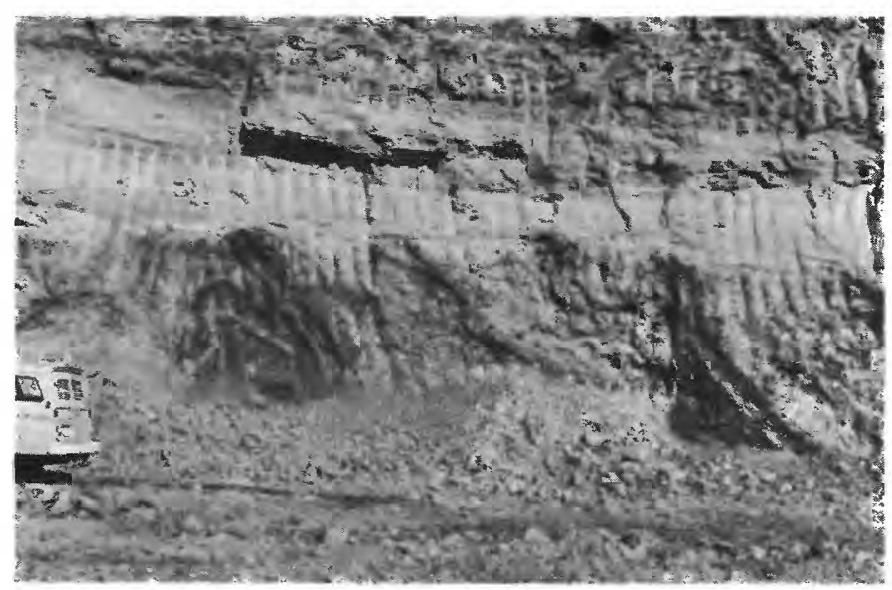

Figure 14. - Contorted lignite in west wall of Petrotomics Co. Section 15 pit. Because overlying beds are undisturbed, contortion is probably due to compaction and flowage of lignitic material shortly after deposition. (NE1/4 sec. 15, T. 27 N., R. 78 W.)

Rocks in the southeastern part of T. 27 N., R. $78 \mathrm{~W}$. contrast with the characteristic heterogeneous mixture of fine- and coarse-grained rocks of most of the central part of the Shirley Basin. In this area the entire Wind River Formation, as much as 300 feet thick, is composed of medium to very coarse grained sandstone having few or no siltstone partings. Several large tributary streams, flowing down the west flank of the early Tertiary basin, joined the trunk stream in this area, and sand was probably deposited when the carrying power of the water decreased abruptly where the tributary streams joined the trunk stream.

The Wind River Formation in the Shirley Basin is characterized by yellow-weathered sandstone outcrops, greenish-gray shale, significant amounts of lignite in the shale and coalified material in the sandstone, a lack of volcanic constituents in the clastic rocks, and the almost complete absence of diabase in the conglomerate. In the central part of the basin the conglomerate contains no diabase, and the pebbles are composed principally of dense siliceous rock. On the flanks of the basin near the source of the detritus, the conglomerate contains cobbles of intensely weathered diabase and moderately weathered coarse-grained granitic rocks. In contrast, the White River and younger formations throughout the basin contain fresh hard pebbles, cobbles, and boulders of coarse-grained diabase and granitic rocks. The degree of weathering and disintegration of the coarse-grained rocks probably reflects climatic differences at the time of deposition of the various formations-moist, semitropical in early Eocene time, becoming semiarid in late Oligocene time.

The conglomerate gradually changes in composition from the base of the Wind River Formation upward. Most conglomerate beds in the basal part of the formation contain cobbles and boulders from the dense sedimentary units of the Paleozoic and Mesozoic formations, and in a few places the conglomerate is composed almost entirely of these rocks. With increasing distance above the base of the formation, the amount of granitic material increases, and the granitic material becomes the principal constituent in the conglomerate at the top of the formation. This gradual change in the lithology of the conglomerate reflects the gradual erosion of the sedimentary rocks from the flanks of the granite cores and the exposure of the cores in the uplifts bordering the Shirley Basin as well as the gradual burial of the sedimentary rocks low on the flanks.

Fossil vertebrates collected from the Wind River Formation and identified by Frank C. Whitmore (written commun., 1961, 1962, 1965) are as follows: NE $1 / 4$ sec. 19, T. 27 N., R. 76 W., Albany County, Wyo.

Phenacodus cf. primaevus Cope

Hyrachyus sp.

Crocodile scutes

Garpike scales

SW $1 / 4$ sec. 31 , T. 27 N., R. 79 W., Carbon County, Wyo. Coryphodon sp.

SW $1 / 4$ sec. 15, T. 29 N., R. 80 W., Natrona County, Wyo. Hyrachyus sp.

Brontops sp.

SW $1 / 4$ sec. 23 , T. 28 N., R. 80 W., Natrona County, Wyo. cf. Coryphodon Hyracotherium sp.

Fossil pollen collected from lignitic material in the Utah Construction and Mining Co. mine and Petro- 
tomics Co. Section 9 pit were identified by Estella Leopold (written commun., 1964, 1967) as follows: SW $1 / 4$ sec. 28 , T. 28 N., R. 78 W., Carbon County, Wyo. Cicatricosisporites 1 (USGS paleobotany loc. D4012)

\section{Eleagnus}

Platycarya

Dinoflagellates and hystrix ${ }^{1}$

Aquilapollenites ${ }^{1}$

Nyssa type

Caryapollenites

Monosulcites (reticulate form)

Tilia

Corrugatisporites

Pistillipollenites

Proteacidites (round form) ${ }^{1}$

NE $1 / 4$ sec. 9, T. 27 N., R. 78 W., Carbon County, Wyo. (USGS

Platycarya
Castanopsis
Osmunda
Pterocarya
Carya
Nertera
Ulmus
cf. Tilia
cf. Nyssa
Eucommia(?)
paleobotany loc. D3426)

Fossil leaves collected by R. V. Bailey from carbonaceous shale about 200 feet above the base of the Wind River Formation in the Utah Construction and Mining Co. mine were identified by Jack A. Wolfe (written commun., 1962) as follows:

Lygodium kaulfussii Heer

Eugenia(?) cf. E.(?) americana (Lesq.) MacGin

Fossil evidence shows the Wind River Formation to be of early Eocene age and to have been deposited in a tropical or semitropical climate. It is predominantly fluvial in origin although lacustrine facies are present, particularly near the top of the formation.

\section{WAGON BED FORMATION}

The Wagon Bed Formation, of middle and late Eocene age, is present in the eastern and western parts of the Shirley Basin, but it was completely removed by pre-lower Oligocene erosion in the central part. The name Wagon Bed was first used by Van Houten (1964) to identify middle and upper Eocene deposits in the Beaver Divide area of Fremont County, Wyo. Contrary to Van Houten's philosophy that deposits "accumulated separately in different structural basins $* * *$ should be assigned to different formations," the name Wagon Bed is herein

\footnotetext{
IForms probably redeposited from Upper Cretaceous sediments.
}

extended to the Shirley Basin to identify deposits similar in age and lithology to those described by Van Houten.

Rocks of middle and late Eocene age had not been recognized in the area prior to the start of the Shirley Basin project, but they had been recognized in the Alcova Dam area, about 24 miles to the northwest, by N. M. Denson (oral commun., 1961). Where present, the Wagon Bed Formation conformably overlies the lower Eocene Wind River Formation and is unconformably overlain by the Oligocene White River Formation. It consists of a series of interbedded coarse-grained arkosic sandstone beds and silicified claystone beds, generally light greenish yellow and sufficiently indurated to form prominent ledges that contrast with the rounded slopes of the overlying and underlying softer formations. Red hematitic splotches or concretionary stains are characteristic of most exposures. The beds in the formation have considerable lateral continuity, and the bedding is fairly well defined.

The top of the Wagon Bed Formation is probably everywhere an erosion surface, and the original maximum thickness of the formation is unknown. The maximum measured thickness of the Wagon Bed in the Shirley Basin area is about 155 feet in an exposure in the SE1/4 sec. 15, T. 27 N., R. 77 W., Albany County, Wyo. This may approach the original maximum thickness. A measured section of this exposure follows:

Measured section of Wagon Bed Formation in the Shirley Basin area, SE1/4 sec. 15, T. 27 N., R. 77 W., Albany County, Wyo.

Top of exposure.

Wagon Bed Formation:

1. Claystone, silty, indurated, silicified, light-olive-green

2. Sandstone, very coarse grained, poorly sorted, siliceous, clay-cemented, off-white; orange and red stains in irregular patches.

3. Claystone, silty, indurated, light-tan; contains scattered coarse sand grains.

4. Sandstone, very coarse grained, siliceous, clay cemented, off-white. 28

5. Sandstone, very coarse grained; interbedded with silty, light-olive-green claystone.

6. Conglomerate, crossbedded, poorly sorted, buff ; light-pink irregular stains, pebbles to $1 / 2$ in. in diameter.

7. Sandstone, very coarse grained, poorly sorted, clay-cemented; some intercalated claystone beds

8. Claystone, silty, indurated, light-tan; contains a few very coarse sand grains........................... 11

9. Sandstone, very coarse grained, clay-cemented........ 3

10. Claystone, silty, silicified, light-olive-green; some coarse sand grains. 
Wagon Bed Formation - Continued

11. Sandstone, very coarse grained, clay-cemented........ 4

12. Claystone, indurated, silicified; interbedded with sandy claystone; weathers nodular.............. 32

13. Sandstone, very coarse grained, clay-cemented; red and orange concretionary stains.................... 2

14. Claystone, silty, silicified, light-olive-green............. 4

15. Conglomerate, sand, and gravel; siliceous; pebbles to 2 in. in diameter.

Total measured Wagon Bed Formation

Conformable contact.

Wind River Formation.

Lake beds, mostly fresh-water limestone, are present in the basal part of the Wagon Bed Formation in two areas in the Shirley Basin. In and near secs. 5 and 6, T. 27 N., R. 77 W., a lower nodular fresh-water limestone about 2 feet thick overlies a very coarse grained off-white sandstone of the Wind River Formation. The limestone is overlain by 6 feet of pink-hued and greenish-yellow silty claystone and interbedded coarse to very coarse grained sandstone. Above the claystone are nodular limestone, sandy limestone, and limy sandstone beds having a total thickness of 3 feet. Windblown Holocene sand overlies the upper limestone.

In secs. 24 and 25, T. 27 N., R. 77 W., and for 2 miles eastward, limestone beds as much as 44 feet thick are exposed in several small cuestas. The lowest exposed limestone rests on siltstone or on what appears to be a lignitic soil in the Wind River Formation. A measured section of the thickest exposure follows:

Measured section of the lower part of the Wagon Bed Formation in the NE1/4 sec. 30, T. 27 N., R. 76 W., Albany County, Wyo.

Top of exposure.

Wagon Bed Formation:

1. Limestone, medium-gray, poorly bedded; contains fossil gastropods.....................................15

2. Clay, silty, yellowish-buff ; calcareous at top................13

3. Limestone, poorly bedded, white, fossiliferous..........16 Total measured lower part of the Wagon Bed Formation.

Conformable contact.

Wind River Formation.

The indistinct contact between the Wind River and Wagon Bed Formations is difficult to see in the field. In the eastern part of the area, the contact has been placed at the base of the lowest fresh-water limestone or, in the absence of lacustrine rocks, at the base of the lowest clay-cemented tuffaceous sandstone bed. Vertebrate fossil evidence shows the limestone to be early middle Eocene in age, and heavy mineral studies by N. M. Denson (oral commun., 1966) show a distinct mineralogical break at the base of the lowest sandstone of the Wagon Bed.

In the western part of the Shirley Basin the lacustrine deposits and the clay-cemented sandstone beds are absent, and the Wagon Bed Formation comprises a 40 - to 100 -foot-thick sequence of silicified bentonitic claystone and tuffaceous silty claystone. A measured section on the east side of Chalk Mountain follows:

Measured section of the Wagon Bed Formation on Chalk Mountain in the SE1/4 sec. 13, T. 28 N., R. 81 W., Carbon County, Wyo.

White River Formation.

Feet

Unconformity.

Wagon Bed Formation:

1. Claystone, silty, blocky, indurated; tan and sandy at base, greenish tan at top...

2. Siltstone, tuffaceous, silicified, nodularweathering, off-white; forms ledges.......................13

3. Claystone, silty, silicified, brown to pale-green..........18

4. Siltstone, tuffaceous, silicified, nodularweathering, off-white; forms ledges........................13

5. Siltstone, tuffaceous, indurated, nodular, $\tan . . . . . . . . . .10$ Total measured Wagon Bed Formation...................64 Conformable contact.

Wind River Formation.

At some places in the Shirley Basin area, although not at the measured sections, the contact between the Wagon Bed and the overlying White River Formation is marked by a $1 / 4$ - to $1 / 2$-inch-thick bed of translucent silica that weathers in small chips and litters the slopes below the outcrop. The material is not fluorescent. It is epigenetic and was probably leached from the overlying White River Formation and deposited on the impermeable upper bed of the Wagon Bed Formation.

In the Beaver Divide area in Fremont County, Wyo., many of the tuffaceous beds of the Wagon Bed Formation have been altered to various zeolite minerals. Samples of tuffaceous members of the Wagon Bed Formation from the Shirley Basin were examined by R. A. Sheppard, who reported (oral commun., 1967) the absence of zeolites in all samples and the presence of relatively fresh shards and considerable glass in some of them. He postulated that the highly alkaline environment necessary for the formation of zeolites has not existed in the Shirley Basin area since deposition of the Wagon Bed sediments.

Vertebrate fossils are sparse in the Wagon Bed Formation in the Shirley Basin area, and only one diagnostic fossil was found. It was identified by G. Edward Lewis (written commun., 1965) as "a fragment of the front part of a right mandibular ramus of Notharctus tenebrosus Leidy with the alveoli of 
$/ C, P_{1}$, and $P_{2}$; the roots of $P_{3}$; and the complete $\mathrm{P}_{4}$ and $\mathrm{M}_{1}$." This lemuroid primate is a characteristic faunal element of the lower part of the middle Eocene Bridger Formation of Wyoming.

Lithologically similar strata in the Beaver Divide area of Wyoming were shown by Van Houten (1964) to be of middle and late Eocene age. Since the middle Eocene fossil was near the base of the Wagon Bed Formation in the Shirley Basin, these strata are here considered to be of middle and late Eocene age. However, it is possible that the rocks are principally middle Eocene and that the late Eocene was a period of erosion, during which the middle Eocene deposits were removed from the central part of the Shirley Basin area.

\section{WHITE RIVER FORMATION}

The terms "White River deposits, formations, or beds" were used by Meek and Hayden (1858) to describe fine-grained clastic rocks on the east side of the Missouri River near the confluence with the White River in South Dakota. The use of the name has been extended to similar deposits in Nebraska, Wyoming, Colorado, North Dakota, and Montana. Darton (1898) divided the White River Group into the Chadron (lower) and Brule (upper) Formations. In central Wyoming, the term White River Formation, in preference to White River Group, is generally used for rocks of Oligocene age-that practice is followed in this report.

The White River Formation is exposed in much of the northern part of the mapped area; it is particularly well exposed on the steep slopes of Bates Hole. For mapping, the formation has been divided into a lower member of fine-grained rocks and an upper member of interbedded fine- and coarse-grained rocks.

The lower member is predominantly fine-grained tuffaceous siltstone, although in some areas there is considerable claystone, sandstone, tuff, conglomerate, or fresh-water limestone near the base. It is as much as 400 feet thick in exposures along the east side of Bates Hole, and drilling east of these exposures indicates that it may be slightly thicker in that area. The upper member consists of tuffaceous siltstone interbedded with very coarse grained sandstone and boulder conglomerate. Thicknesses of as much as 350 feet in the upper member have been measured along the east side of Bates Hole.

The lower member rests unconformably on rocks of the Wagon Bed or older formations in the eastern part of the Shirley Basin area; on rocks of the Wind River Formation in the central part of the area, where the Wagon Bed Formation was completely removed by late Eocene or early Oligocene erosion; and on rocks of the Wagon Bed Formation in the western part of the area. There is no apparent angular discordance between the White River Formation and older rocks of Tertiary age. The contact between the White River and the older formations is sharp and easily recognized in the field except where the White River rests on the eroded surface of the Wind River. In these areas there is considerable reworked material in the base of the White River, and the contact is difficult to locate precisely.

In the eastern part of the area the base of the White River Formation contains many channel-fill conglomerate beds composed of poorly sorted coarsegrained sand, subangular to angular pebbles, generally less than 1 inch in diameter, and a few rounded cobbles as much as 6 inches in diameter. The pebbles and cobbles are principally granitic rocks, but in some areas as much as 15 percent of the material may be limestone, chert, diabase, and quartzite. In Tps. 27 and 28 N., R. 77 W., many short narrow sinuous ridges or irregular masses of conglomerate, too small to be shown on the map, rest on a slightly tilted dipslope of Wagon Bed rocks. These are erosional remnants of White River deposits that filled shallow channels in the top of the Wagon Bed Formation. Similar conglomerate beds northeast of the Holiday Ranch (northeast of the mapped area) contain an early Oligocene vertebrate fauna (P. O. McGrew, oral commun., 1964).

Overlying the channel conglomerate in this eastern part of the area or, where the conglomerate is absent, resting on the eroded surface of the Wagon Bed Formation, is a monotonously uniform sequence of tuffaceous siltstone and mudstone beds which are generally pinkish gray, pale tan, or off white and which range in thickness from an inch or less to several feet. Individual beds have considerable continuity and were apparently deposited on flood plains or in shallow playa-type lakes. The siltstone weathers to a blocky rubble that forms small talus slopes below ledgy outcrops.

On the western flank of the Laramie Mountains, the White River Formation laps on many of the older Mesozoic and Paleozoic rocks, and in some places detritus from the older rocks is incorporated in the White River Formation. This is particularly true near paleooutcrops of the soft, easily eroded Red Peak or Goose Egg Formation where the White River is a brick-red siltstone having an appearance strikingly similar to that of the red beds on which it laps. Near paleooutcrops of Mowry Shale, the White River may consist principally of shale frag- 
ments cemented with the silty material that elsewhere composes the lower member of the formation. High on the flanks of the basin, where the White River Formation laps on the old indurated rocks such as the Precambrian granite, Madison Limestone, or Casper Formation, the contact is sharp, and almost no detritus from the older rocks is incorporated in the onlapping part of the White River. This fact suggests rapid deposition of White River sediments on a surface undergoing minimal weathering and erosion.

In the central part of the Shirley Basin area, the White River Formation rests on the eroded surface of the Wind River Formation, and the contact has no apparent angular discordance. From the southeast corner of Bates Hole eastward to the Little Medicine Bow River, the Wind River-White River contact is difficult to locate on the surface, for the outcrops are poor and there is no distinctive lithologic break between the two formations. Data from exploratory drilling south of Moss Agate Ridge were used to determine the location of the contact in that area. The contact was selected at the base of a chocolate-brown claystone that overlies a very coarse grained off-white sandstone. Similar chocolatebrown claystone, half a mile north of the Utah Construction and Mining Co. shaft, contained White River (Chadron) vertebrate fossils. East of sec. 33, T. 28 N., R. 78 W., the brown clay is not present, or at least it was not recognized in drill cuttings, and for a distance of almost 2 miles there is no distinctive bed near the contact that can be used as a horizon marker. The mapped position of the contact in this area is therefore only approximate. Northward along the east side of Bates Hole, the contact is not sharp due to some reworked Wind River sand incorporated in the base of the White River, but the zone of questionable designation is only a few feet thick.

A sequence of tan, brown, green, or red clayey siltstone beds directly overlies the Wind River Formation in much of the central part of the Shirley Basin area. These rocks are plastic and waxy and weather to steep slopes covered with blocky chips and spherical masses of clayey siltstone. They are well exposed in the W1/2 sec. $15, T .29$ N., R. 80 W., where they are overlain by the tuffaceous siltstone that makes up the bulk of the lower unit of the White River Formation, and in the NE1/4 sec. 21, T. 28 N., R. 79 W., where they are overlain by a sequence of lake beds. At some intervening points the clayey siltstone beds are absent, and tuffaceous siltstone rests directly on the eroded surface of the Wind River Formation. In sec. 15 the clayey silt- stone beds are chocolate brown or pale green and blocky and are interbedded with coarse-grained arkosic tuffaceous sandstone. The clayey siltstone beds range in thickness from 10 to 20 feet; the sandstone beds, from 5 to 15 feet. The sequence is about 100 feet thick, and it is capped by a ledgeforming sandstone. In sec. 21 the clayey siltstone beds are mottled red and green and contain sparse, isolated, coarse quartz grains. Here the sequence is about 50 feet thick and contains some sandstone in the lower part. The clayey siltstone beds have been seen at the base of the White River Formation only where the Wagon Bed Formation has been completely eroded and the White River rests on the eroded surface of the Wind River Formation. These beds are a distinctive lithologic unit, and they are thought to be the earliest Oligocene deposits in the area, perhaps similar in age to the Yoder Formation of Schlaikjer (1935) in eastern Wyoming (P. O. McGrew, oral commun. 1964).

In the southeast corner of Bates Hole, and for about 5 miles eastward, a sequence of lacustrine acidic tuff, tuffaceous siltstone, and silicified limestone beds overlies the basal White River clayey siltstone (fig. 15). These beds are as much as 45 feet thick, are resistant to erosion, and form the prominent cuesta known as Moss Agate Ridge. The sediments now comprising these beds were deposited in a shallow lake at least 5 miles long and 2 miles wide, and perhaps much more extensive. The base of the lake-bed sequence is $50-75$ feet above the base

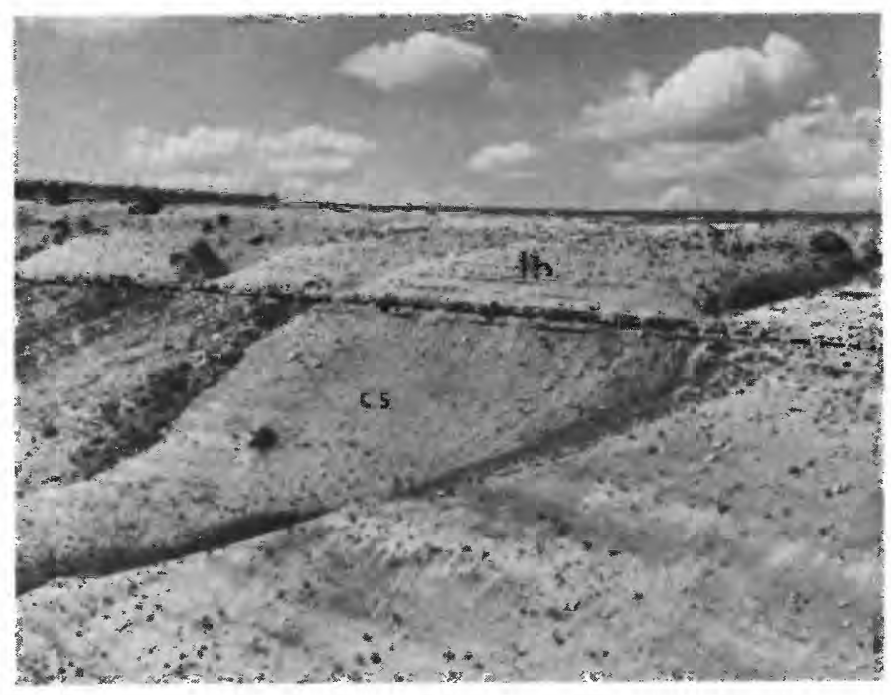

FIGURE 15. - Lower part of the lower member of the White River Formation at the southeast corner of Bates Hole (sec. 21 , T. 28 N., R. 79 W.), showing clayey siltstone (cs) at the base of the White River Formation and lake-bed sequence (Ib) overlying clayey siltstone and underlying Moss Agate Ridge, an erosional cuesta extending 5 miles southeast of this exposure. 
of the White River Formation. The lower part of the lakebed sequence is silty limestone replaced in part by silica leached by ground water from the overlying tuff and tuffaceous siltstone and deposited in the rocks directly overlying impervious claystone.

A section from the base of the White River Formation through the lake-bed sequence follows:

Section of base of White River Formation measured in sec.21, T. 28 N., R. 79 W., at the southeast corner of Bates Hole

Top of exposure.

Feet

White River Formation:

1. Tuffaceous siltstone, blocky, buff to light-tan; in beds 1-6 in. thick.

2. Sandy siltstone, massive, indurated, calcareous, light-tan; forms ledges.................... 2.5

3. Tuffaceous siltstone, sandy, blocky, pale-pink and brown, thin-bedded.

4. Sandstone, fine- to medium-grained, silty, tuffaceous, crossbedded, off-white; beds about $1 / 8$ in. thick.

5. Sandstone, crossbedded, off-white; pebbles as much as $1 / 2 \mathrm{in}$. in diameter.

6. Siltstone, blocky, light-brown.............................. 3.5

7. Tuff, massive, white to pinkish-white; grades to bedded tuffaceous siltstone at top.................. 3.0

8. Siltstone, blocky, tuffaceous, pinkish-brown.......... 4.0

9. Sandstone, very coarse grained, siliceous; contains calcite-cemented siltstone pebbles 1 in. in diameter

10. Marl, off-white; replaced in large part by silica; dendritic manganese.

aystone, silty, pink- and green-mottled, blocky

12. Chalcedony (moss agate); thin claystone interbeds

13. Claystone and clayey siltstone, bentonitic, blocky, red- and green-mottled. Banded silica in top $5 \mathrm{ft}$.

Total measured base of White River

Formation

Unconformity.

Wind River Formation.

A section of the lake-bed sequence measured in the bank of Spring Creek in sec. 19, T. 28 N., R. 78 W., about 4 miles east of the Bates Hole measured section, contains 36 feet of strata comprising principally calcareous siltstone, silty limestone, and tuffaceous siltstone, all somewhat silicified. The lake beds were originally more extensive than at present, as shown by the fact that they end abruptly on the east, south, and west in exposures 30-70 feet thick, obviously carved by erosion, perhaps starting in the Pleistocene. On the north, the lake beds phase out laterally by a gradual change in facies to the floodplain tuffaceous siltstone characteristic of most of the lower member of the White River Formation.
The upper part of the lower member of the White River Formation in the central part of the area, as in the eastern part, comprises a 300 - to 350 -footthick sequence of light-pink, tan, or off-white tuffaceous siltstone and mudstone beds. Beds range in thickness from a fraction of an inch to several feet, and relatively thin beds can be traced laterally for several thousand feet. Thick beds or groups of beds have been traced as far as 2 miles.

A section of the lower member of the White River Formation follows:

Section of lower member of White River Formation measured in sec. 26, T. 29 N., R. 80 W., on the east side of Bates Hole

Upper member, White River Formation.

Conformable contact.

Lower member, White River Formation:

1. Siltstone, tuffaceous, off-white; in beds as much as $5 \mathrm{ft}$ thick

2. Siltstone, off-white to light-tan; sandy at top; beds a few inches to $5 \mathrm{ft}$ thick

3. Siltstone, off-white to light-tan; beds 2 in. to $3 \mathrm{ft}$ thick

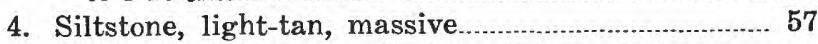

5. Siltstone, tuffaceous, off-white, thin-bedded (interpreted from drill cuttings)

Total measured lower member of White River Formation

Unconformity.

Wind River Formation.

The lower two-thirds of the lower member of the White River Formation weathers in even, steep slopes covered by blocky and rounded siltstone fragments. The upper third weathers in almost vertical cliffs due in part to cementation of the siltstone and in part to protection from erosion offered by the moderately indurated siltstone and conglomerate in the upper member. The character of the east side of Bates Hole near triangulation station Rimo (sec. 26 , T. 29 N., R. 80 W.) is shown in figure 16.

In the western part of the area, the lower member of the White River Formation rests unconformably on the Wagon Bed Formation without angular discordance. The lake beds and silty claystone present in the central part of the area are absent in the western part, and the lower member is composed entirely of siltstone, tuffaceous siltstone, and minor amounts of fine-grained sandstone. The lower member, as measured on Chalk Mountain in sec. 31, T. 28 N., R. 80 W., is about 265 feet thick. The combined thickness of the lower member and the Wagon Bed Formation in the Chalk Mountain section is 331 feet, about the same as the thickness of the lower member on the east side of Bates Hole, where the Wagon Bed Formation is missing. 


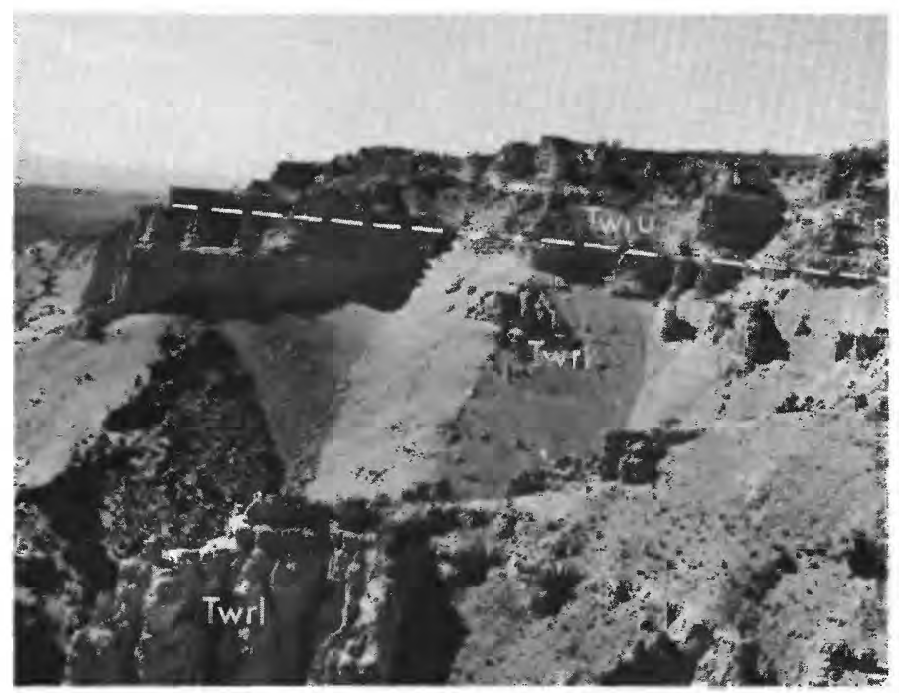

Figure 16. - Lower member (Twrl) of the White River Formation, showing rubble-covered steep slopes of lower two-thirds and steep cliffs of upper third of member. Cliffforming beds of upper member (Twru). Looking north on east side of Bates Hole (NE1/4 sec. 27, T. 29 N., R. 80 W.).

Thin sandstone dikes in mudstone, similar to the mudstone dikes described by Rich (1962) in the White River Formation in the Clarkson Hill area 15 miles northeast of Bates Hole, are present in the lower member along the west side of Bates Hole. One, exposed in sec. 6, T. 27 N., R. 80 W., is 2 inches wide and 75 feet long and is filled with medium- to coarse-grained sand. It pinches out downward, but upward it ends abruptly at the lower contact of a sandy siltstone bed of the lower member. There is no apparent displacement of beds cut by the dike. It may represent a shrinkage crack formed prior to deposition of the overlying sandy beds and filled concurrently with the deposition of the sandy material.

The upper member of the White River Formation is well exposed on both sides of Bates Hole, and the lower part of this member forms the north rim of an erosional scarp that extends from Bates Hole eastward, along the Carbon-Natrona County line, to the west flank of the Laramie Mountains. The upper member has a consistent lithology over most of the Shirley Basin area and comprises tuffaceous siltstone beds, similar to those in the lower member, interbedded with conglomerate and coarse-grained arkosic sandstone beds composed principally of Precambrian granitic and metamorphic rocks. Over most of the area the upper member is separated from the lower one, by a well-defined break in sedimentation, representing an interruption of very short duration which did not necessarily occur over the entire area. It is considered to be a diastem rather than an unconformity. Relief on the eroded surface of the lower member in some places is as much as 50 feet, but generally it is a few tens of feet or less. Figure 17 shows the configuration of the contact in the steep wall of the south fork of Chalk Creek in sec. 9, T. 29 N., R. 79 W.

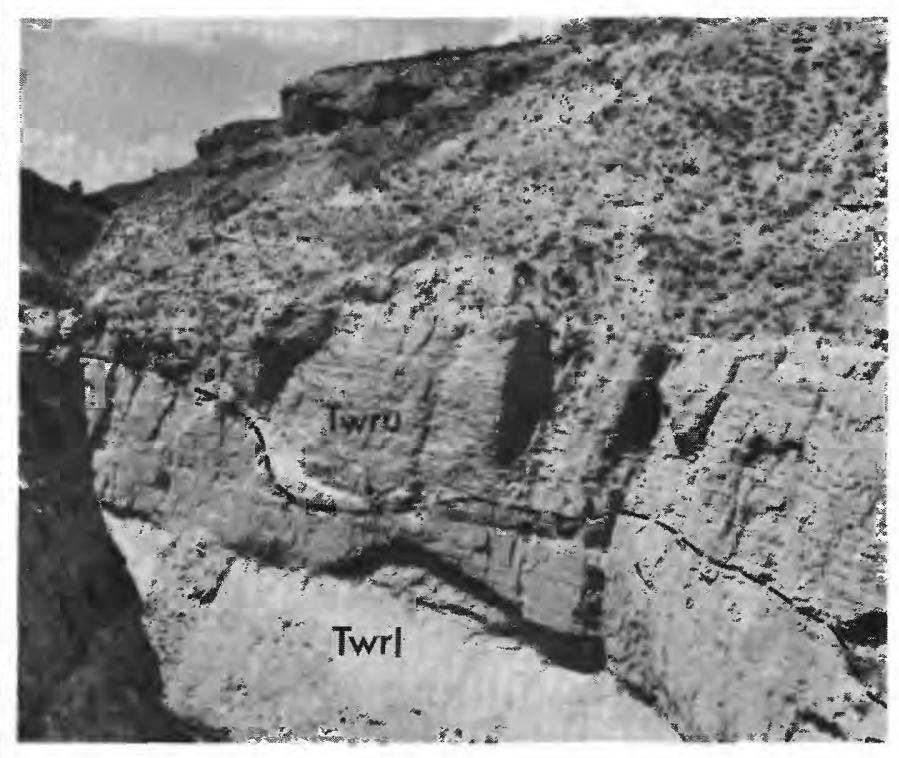

FIGURE 17. - View showing diastem between the upper (Twru) and lower (Twrl) members of the White River Formation exposed in Chalk Creek ( $\mathrm{NE}^{1} / 4$ sec. 9, T. 29 N., R. 79 W.). Steep rock wall is about 100 feet high.

Over much of the outcrop area the base of upper member is marked by tuff beds, conglomerate beds, or both, but for about 1 mile in sec. 26, T. 29 N., R. $80 \mathrm{~W}$., the contact is poorly defined by a tuffaceous siltstone; there appears to have been no break in sedimentation in this area.

The upper member contains from three to five beds of coarse-grained sandstone and conglomerate that generally range in thickness from a few feet to about 20 feet, although a 50-foot-thick conglomerate bed is exposed on the west side of Bates Hole in sec. 25 , T. 28 N., R. $81 \mathrm{~W}$. The conglomerate is composed principally of arkosic sand and of pebbles, cobbles, and boulders of granite, diabase, and metamorphic rocks. Very few rocks younger than Precambrian were noted in the exposures, although in a few places pebbles of siltstone eroded from the White River Formation are present in the conglomerate. The coarse material is as much as 18 inches in diameter and is rounded to subangular. The degree of rounding increases as diameter decreases. The fine-grained material consists of individual quartz and feldspar grains or grain aggregates, remarkably fresh and generally angular. The sandstone is crossbedded. 
No individual conglomerate bed in the upper member is continuous throughout the area, and in the southeastern part of sec. 13 , T. 29 N., R. 80 W., no conglomerate beds are in the member. In the very good exposures along the east side of Bates Hole, individual conglomerate beds can be seen to extend for a few thousand feet to several miles. Some conglomerate beds terminate abruptly in what appear to be the steep banks of stream channels; others thin and terminate in what must have been a gravelly sheet wash. One thick conglomerate bed splits into two thinner ones which are separated by about 15 feet of siltstone. In the erosional scarp extending eastward from Bates Hole to the Laramie Mountains, single conglomerate beds near the base of the upper member, or at least a basal zone of interbedded acidic tuff and conglomerate beds about 50 feet thick, extend the entire distance, about 15 miles (fig. 18).

The conglomerate beds are intercalated in a sequence of well-bedded tuffaceous siltstone, mudstone, and fine-grained sandstone almost identical with the beds in the lower member. Individual fine-grained beds range in thickness from a few inches to several feet, and the aggregate thicknesses of the beds between the conglomerate beds range from 5 to 50 feet. The fine-grained rocks are somewhat darker in the upper member than in the lower member, and the upper member, particularly from a moderate distance, is noticeably darker than the lower member.

Two measured sections of the upper member, one on the west side of Bates Hole and the other on the east side, follow:

Section of upper member of the White River Formation on Chalk Mountain measured in sec. 31, T. 28 N., R. 80 W., on the west side of Bates Hole

Arikaree Formation.

Conformable contact.

Upper member, White River Formation:

1. Siltstone, massive, tan; stringers and pockets of sand and gravel; calcareous concretions

2. Sand and gravel; boulders of white granite and diabase as much as $12 \mathrm{in}$. in diameter. 10.0

3. Siltstone, $\tan$; calcareous concretions................. 18.5

4. Sand and gravel; cobbles of white granite and diabase as much as 6 in. in diameter........ 3.5

5. Siltstone, tan, massive, and interbedded fine-grained sandstone.

6. Sand and gravel; pink and white granite and diabase; rounded to subangular; maximum diameter about 14 in

Feet iltstone, tan, thin-bedded, and fine-grained

off-white sandstone.
8. Sand and gravel; red and pink granite pebbles; maximum diameter about 2 in
Upper Member, White River Formation - Continued

9. Siltstone and sandstone, thin-bedded, tan to off-white.

Feet

10. Conglomerate; pink and white granite and diabase pebbles; rounded to subangular; 1 in. in maximum diameter. 28.0

12. Conglomerate; pink and white granite and diabase pebbles; subangular to rounded, crossbedded; some rounded tuff pebbles 2 in. in maximum diameter.

Total measured upper member of the White River Formation 231.0 Conformable contact.

Lower member, White River Formation.

Section of upper member of the White River Formation measured in sec. $26, T .29$ N., R. 80 W., near triangulation station Rimo, on the east side of Bates Hole

Feet

Arikaree Formation.

Conformable contact.

Upper member, White River Formation:

1. Siltstone, massive, $\tan$

2. Conglomerate; red granite cobbles as much

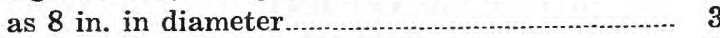

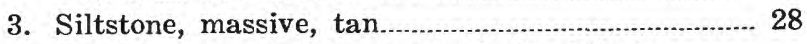

4. Siltstone, tan, and fine-grained off-white to pink sandstone; interbedded with silty limestone lenses; beds as much as $2 \mathrm{ft}$ thick......133

5. Conglomerate; red granite and diabase clasts; boulders as large as 12 in. in diameter............... 4

6. Sandstone, fine-grained, silty, thin-bedded.............. 8

7. Siltstone, sandy, massive, $\tan$.............................. 18

8. Sandstone, off-white; gravel as much as

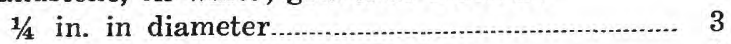

9. Siltstone, tan, massive............................ 8

10. Conglomerate and sandstone, crossbedded.............. 7

11. Siltstone, tuffaceous, thin-bedded, tan; interbedded with sandstone having gravel as much as $1 / 2$ in. in diameter

12. Conglomerate and sandstone, crossbedded; red granite cobbles as large as $8 \mathrm{in}$. in diameter; some siltstone pebbles. 11

13. Siltstone, $\tan$ to off-white, calcareous...................... 66

14. Siltstone, massive, tan Total measured upper member of the White River Formation. 359

Conformable contact.

Lower member, White River Formation.

The conglomerate in the upper member of the White River Formation on the east side of Bates Hole is significantly different from that on the west side. Although granitic rocks are the principal components of the conglomerate in both areas, the character of the granite cobbles and boulders suggests that the clastic debris was derived from two separated lithologically distinct sources. On the east side of Bates Hole the clastic debris is composed principally of the pink granite and gray diabase that characterize the northern end of the core of the Laramie Mountains, and it is almost certain that the conglomerate was deposited in fans by 
streams flowing westward from the Laramie Mountains.

In sharp contrast, the debris in the conglomerate on the west side of Bates Hole is composed principally of light-gray or white granite and gray diabase, rock types characteristic of the core of the mountains southwest and west of the Shirley Basin area. The clear implication is that this conglomerate was deposited by easterly flowing streams that originated on the northeast flank of the south end of the Granite Mountains.

These data indicate that in Oligocene time the position of the major stream that drained the low area between the Granite and Laramie Mountains was near Bates Hole, or about 10 miles west of its position in early Eocene time.

Previous workers have misidentified rocks in the upper member of the White River Formation in the Shirley Basin area. Roehler (1958) and Shipp (1959) considered them to be part of an unnamed sequence of Miocene age; Peterson (1935) and Konkel (1935) termed them the Arikaree Formation; and Love, Weitz, and Hose (1955), Weitz and Love (1952), and Weitz, Love, and Harbison (1954), in compiling State and county geologic maps, showed them as part of an undivided sequence of Miocene and Pliocene age.

Vertebrate fossils, most of which were collected near the base of the upper member but some of which were as much as 160 feet above the base, show that this sequence of siltstone, sandstone, and conglomerate beds is, in fact, of middle Oligocene age (Orellan provincial age of Wood and others, 1941) and that it is the central Wyoming equivalent of the Brule Formation of eastern Wyoming and western Nebraska. The change in lithology from the finegrained rocks in the lower member to the intercalated fine- and coarse-grained rocks of the upper member suggests uplift of the source areas in the Laramie and Granite Mountains, vigorous erosion and transportation by streams flowing from the mountains, and deposition of extensive alluvial fans on the flood plains at the foot of the mountain fronts.

Rocks equivalent to the upper member of the White River Formation probably are more extensive than commonly believed, and their recognition is imperative if the geologic history of the region is to be correctly interpreted. For example, Rich (1962) stated that middle and upper Oligocene (Brule) rocks are absent in the Clarkson Hill area of Natrona County, 15 miles northwest of Bates Hole, either not having been deposited or, if deposited, having been removed by post-early Oligocene to pre-early Miocene erosion. However, the lower few hundred feet of a sequence he designated as lower and middle Miocene is lithologically similar to the upper member of the White River Formation in the Bates Hole area, and the fossil evidence of early Miocene age was from rocks about 500 feet above the base of the sequence. Possibly, therefore, some of the rocks included in the base of the lower and middle Miocene sequence by Rich are actually of middle and late Oligocene age. Furthermore, reconnaissance mapping and studies of heavy mineral concentrates from fine-grained rocks by Denson (1965; oral commun., 1967) have lead him to conclude that the upper member of the White River Formation can be recognized almost continuously from the Shirley Basin westward to the Gas Hills area in Fremont County, as well as in eastern Wyoming along the east flank of the Laramie Mountains.

Vertebrate fossils were collected from the lower 75 feet of the lower member of the White River Formation and from the lower 160 feet of the upper member. They were identified by F. C. Whitmore and G. Edward Lewis (written commun., 1961, $1962,1963,1965)$ as follows:

Upper member:

Secs. 4, 5, and 8, T. 28 N., R. 79 W.

Leptomeryx evansi Leidy

Palaeolagus haydeni Leidy

Fragments of bones of rhinoceros and camel

Sec. 31 , T. 29 N., R. 79 W., and secs. 25,26 , and 27, T. 29 N., R. 80 W.

Hyracodon nebrascensis Leidy

cf. Poebrotherium

Metamynodon sp.

Subhyracodon occidentalis (Leidy)

Leptauchenia sp.

Poebrotherium sp.

Leptomeryx cf. evansi Leidy

Stylemys sp.

Lower member:

Secs. 15, 22, and 27, T. 29 N., R. 80 W.

Brontops sp.

cf. Menodus

Leptomeryx, between $L$. yoderi and $L$. evansi in size Hesperocyon cf. gregarius (Cope)

Hesperocyon cf. paterculus (Matthew)

Leptomeryx sp.

Sec. 8, T. 27 N., R. 76 W.

cf. Agriochoerus

In the western parts of Nebraska and South Dakota, rocks of Oligocene age are assigned to the White River Group. In the group, two formations, the Chadron (lower Oligocene) and the Brule (middle and upper Oligocene), are recognized, and the Brule was subdivided by Schultz and Stout (1955) into the Orella (middle Oligocene) and the Whitney (upper Oligocene) Members. In central Wyoming these formations are not easily recognized on the 
basis of lithology, and the name White River Formation is generally used for the Oligocene rocks. Correlation between the twofold division of the White River Formation used in this report and the divisions of the White River Group used in Nebraska and South Dakota is uncertain. Fossil evidence indicates that the lower part of the lower member in the Shirley Basin area is Chadronian provincial age and that the lowest part of the upper member is Orellan provincial age. The faunal discontinuity is, therefore, somewhere in the middle or upper part of the lower member. Roehler (1958) suggested that in Bates Hole the discontinuity lies about 50-150 feet above the base of the White River sequence, at the base of the lake beds described earlier in this report. Rich (1962) presented evidence that the discontinuity is at least 600 feet above the base of the White River Formation in an area 15 miles northwest of Bates Hole. It is possible, but by no means certain, that the Chadron-Brule faunal discontinuity corresponds with the lithologic discontinuity between the upper and lower members of the White River Formation in the Shirley Basin area.

No fossils of late Oligocene (Whitneyan provincial age) age were found prior to or during this investigation. However, since no fossils have been found in the upper 200 feet of the upper member, possibly beds equivalent to the Whitneyan are present near the top of the upper member.

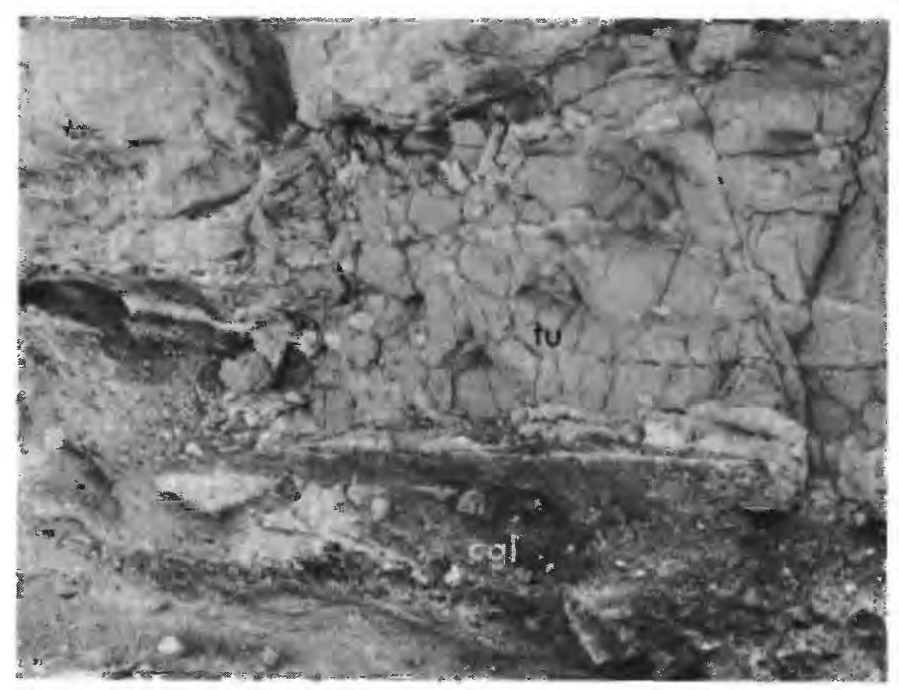

FIGURE 18. - Tuff bed (tu) overlying lowest conglomerate bed (cgl) at base of the upper member of the White River Formation in sec. 31 , T. 29 N., R. 77 W. Note channeling of conglomerate and tuff.

Stratigraphic and faunal evidence suggests that the White River Formation was deposited on flood plains and in fanlike deposits near the mountain fronts. Ash was deposited directly as ash falls or as reworked material washed in and mixed with detritus from surrounding upland areas. The environment appears to have ranged from semiarid desert to stream border-savannah and from temperate to subtropical.

\section{ARIKAREE FORMATION}

The name Arikaree Formation was first used by Darton (1898) to identify a series of gray sands which overlies the Gering Formation and underlies the Ogallala Formation and which is characterized by layers of dark-gray concretions, many of which are tubular. These rocks are present in eastern Wyoming and western Nebraska, and the name was taken from the Arikaree Indians, a tribe that once occupied the area in which the formation was found. The name was generally restricted in use to areas east of the Laramie Mountains until Sato and Denson (1967) applied it to lower Miocene rocks in central Wyoming. Their usage is followed in this report.

In the Shirley Basin area the Arikaree Formation overlies the upper member of the White River Formation with apparent conformity. The Arikaree consists of a series of light-gray tuffaceous fineto medium-grained calcareous sandstone, lenticular conglomerate, and fresh-water limestone beds. The rocks are moderately indurated and generally erode to form steep cliffs.

Rocks of the Arikaree Formation are exposed in the northwestern and western parts of the mapped area, where they have a maximum thickness of about 175 feet. They underlie the flat dip slope of Chalk Mountain and several small outliers to the north, and they cap prominent ridges in the high area northeast of Bates Hole. The Arikaree Formation in the Shirley Basin area is the basal part of a sequence of clastic and volcanic rocks which was originally much thicker, but which has now been largely removed by Quaternary erosion. Data on the original thickness of the Arikaree Formation in the Shirley Basin area are lacking, but Denson (1965) estimated that lower and middle Miocene rocks in central Wyoming averaged about 1,000 feet in thickness.

The contact between the Arikaree and the upper member of the White River Formation is well defined in most areas, but in some places it is gradational. The Arikaree rocks are generally light shades of gray; the White River rocks are light tan, brown, and pink. In some areas there are lenticular conglomerate beds at the base of the Arikaree Forma- 
tion, but for the most part the basal beds are sandstone.

Figure 19 shows the indurated cliff-forming sandstone beds at the base of the Arikaree Formation in the area northeast of Bates Hole. The exposure is principally tuffaceous, arkosic sandstone that contains a few subangular to rounded cobbles and boulders of gray granite and diabase, as much as 18 inches in diameter. Some beds contain considerable calcium carbonate as a cementing material, and these beds weather in ellipsoidal concretionary forms. Blue-black magnetite grains, characteristic of the Arikaree Formation over much of central Wyoming, are present in the sandstone, particularly near the base of the exposure. A section measured about 1 mile north of the exposure shown in figure 19 follows.

Section of Arikaree Formation measured in NW1/4 sec. $7, T$. 29 N., R. 79 W., Natrona County, Wyo.

Top of exposure.

Windblown sand.

Arikaree Formation:

1. Sandstone, tuffaceous, arkosic, white, poorly cemented; contains pebbles and boulders as much as $10 \mathrm{in}$. in diameter (poor outcrops) ..... 15.0

2. Sandstone, tuffaceous, arkosic, light-gray, rounded frosted grains; noticeable black opaque grains; calcareous cement. Irregular bedding $1 \mathrm{in}$. to $10 \mathrm{ft}$ thick; weathers to gnarled surface dotted with very coarse sand grains

3. Sandstone, light-gray, arkosic; frosted grains; traces of calcareous cement (poor outcrops) .... 25.5

4. Sandstone, tuffaceous, light-gray; contains pebbles and boulders as much as 6 in. in diameter, interbedded with silty sandstone.... 34.0

5. Sandstone, tuffaceous, light-gray, silty; numerous black opaque grains; poor cementation (poor outcrops)

6. Sandstone-conglomerate, off-white, crossbedded; subangular to rounded cobbles as much as 6 in. in diameter. 5.0

Total measured Arikaree Formation Conformable contact.

White River Formation.

Chalk Mountain, at the center of the west edge of the mapped area, is capped by an 80-foot-thick sequence of arkosic sandstone, conglomerate, freshwater limestone, and tuffaceous siltstone beds of a light-gray hue. The siltstone and to a lesser extent the sandstone and conglomerate contain calcareous cement. No fossils have been found in these strata, but because of their stratigraphic position, their light-gray color, the presence of considerable calcareous cement, and a probable Granite Mountain source of the clastic debris, they have been mapped as Arikaree. The possibility remains that these strata are a calcareous facies at or near the top of the upper member of the White River Formation-a facies not exposed elsewhere in the Shirley Basin area.

A section measured on the east slope of Chalk Mountain follows:

Section of Arikaree Formation measured on the east slope of Chalk Mountain, sec. 31, T. 28 N., R. 80 W.

Top of exposure.

Feet

Arikaree Formation:

1. Fresh-water limestone, silicified, irregularly bedded, white 13

2. Conglomerate, poorly cemented, rounded to subangular, light-gray; boulders as much as 12 in. in diameter.

3. Fresh-water limestone, silicified, irregularly bedded, gray-white 7

4. Conglomerate, poorly cemented, rounded to subangular, crossbedded, light-gray; cobbles as much as $10 \mathrm{in}$. in diameter; interbedded with sandy calcareous, off-white siltstone. Beds 5-12 ft thick. 46

Total measured Arikaree Formation $\overline{80}$

Conformable contact.

White River Formation.

No fossils were found in the rocks mapped as Arikaree in the Shirley Basin area although they were looked for diligently. The identification of these strata as part of the lower Miocene Arikaree Formation is based on their stratigraphic position, their lithologic similarity to well-dated strata in the Clarkson Hill (Rich, 1962) and Beaver Divide (Van Houten, 1954) areas, respectively 15 and 60 miles to the west, and on the fact that this unit, according to Denson (1965), is

strikingly similar to the Arikaree Formation as defined by Darton *** has been mapped discontinuously from the vicinity of Oregon Buttes along the southwest flank of the Wind River Mountains [Range] through central and southeastern Wyoming into northwestern Nebraska.

The Arikaree Formation in the Shirley Basin area is of fluvial, lacustrine, and eolian origin. These are the youngest eolian sands in the Tertiary rock sequence. The clastic parts of the formation were derived from a granitic and metamorphic terrane of Precambrian age which lay to the west of the area and which now forms the core of the Granite Mountains. Volcanic material, in part ash falls and in part reworked ash from the highlands to the west, constitutes a significant part of the rocks. The heavy-mineral suites from the fine sandstones exposed in sec. 7 , T. 29 N., R. 79 W., contain about 40 percent each of augite and brown hornblende. About 90 percent of the minerals are of volcanic origin (N. M. Denson, oral commun., 1967). Relief 
in the sediment source areas appears to have been considerably less than in Oligocene time but was still sufficient to produce sheet gravel and fluvial conglomerate in the outwash plain.

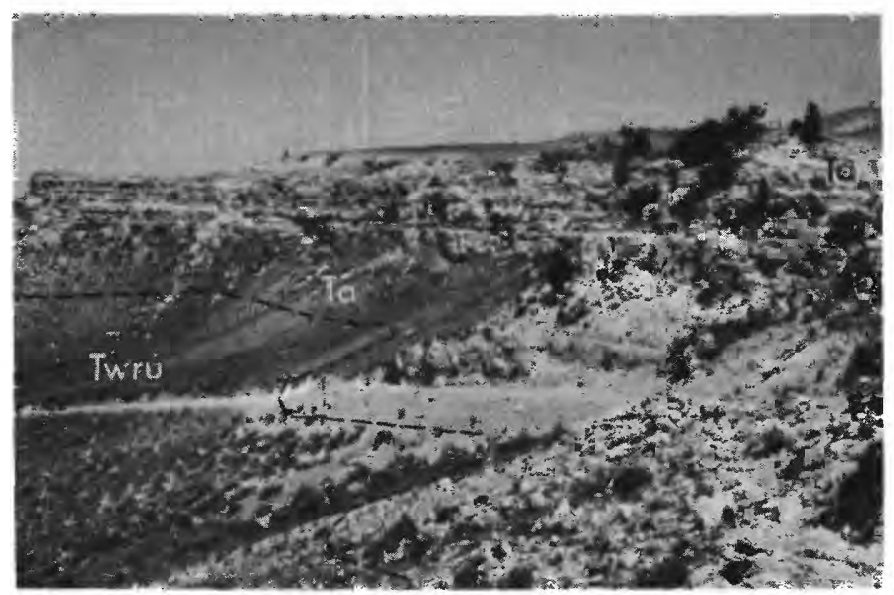

Figure 19. - Cliff-forming calcareous-cemented sandstone (Ta) at base of Arikaree Formation in sec. 18, T. $29 \mathrm{~N}$, R. 79 W., northeast of Bates Hole. The White River Formation, upper member (Twru), is covered by talus.

\section{HIGH TERRACE GRAVEL}

At several places in Bates Hole, as well as in the area drained by the Little Medicine Bow River and its tributaries, terrace gravel caps ridges or hills that rise a few tens to as much as 100 feet above the general terrain. These deposits consist of poorly stratified sand and gravel; the gravel is rounded to subangular and composed principally of granitic and metamorphic rocks. The terrace gravel in the Bates Hole area contains boulders and cobbles of sandstone from the upper member of the White River Formation and probably is reworked from the sandstone and conglomerate exposed in the rim of Bates Hole. It may be of Pleistocene age, but no definitive age data are available.

In the Little Medicine Bow drainage area, the high terrace gravel deposits cap ridges south of the toe of the erosional scarp along the NatronaCarbon County line. These deposits probably are reworked from the conglomerate and sandstone exposed in the scarp, and they are assumed to be of Pleistocene age.

Inasmuch as the high terrace gravel is thin and of limited aerial extent, it was not mapped as a separate geologic unit.

\section{LOW TERRACE GRAVEL}

Terrace gravel is present along the Little Medicine Bow River, Stinking Creek, Elk Creek, and some of the other streams in the area. Most of the material is probably reworked from the soft Tertiary rocks in the headwaters of these streams, but some of the material in the terraces along the Little Medicine Bow River may have been derived directly from the older rocks on the west flank of the Laramie Mountains. Where the low terrace gravel deposits are of sufficient size and thickness to be mapped, they have been included with the alluvium.

\section{ALLUVIUM}

Old alluvium, now being dissected by streams, is present throughout the Bates Hole area and, to a lesser extent, in the area drained by the Little Medicine Bow River. It is primarily fine-grained material eroded from soft Cretaceous and Tertiary rocks. It reaches a thickness of as much as 30 feet in some of the main tributaries of Stinking Creek, and it extends far into their upper reaches (fig. 20). Two stages of alluviation older than the present one can be recognized along Stinking Creek in the Bates Hole area. The old alluvium is younger than the high terrace gravel and probably is Holocene in age.

Alluvium is now being deposited by streams as flood-plain deposits and channel fill. Most of it is fine-grained material derived from the soft rocks in the drainage basins of the major streams and their tributaries.

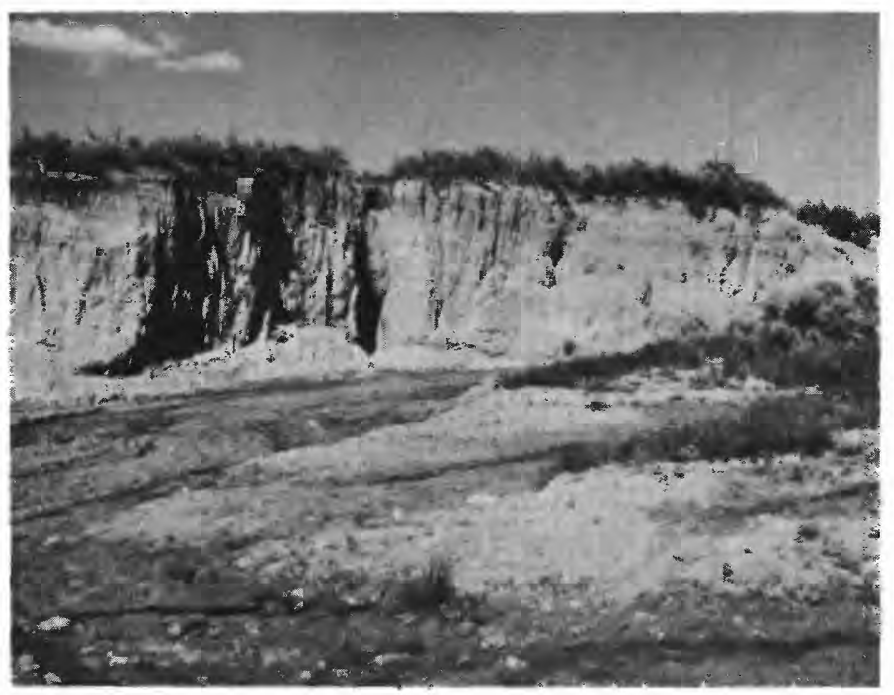

Figure 20. - Exposure of thick old alluvium now being actively dissected by Lawn Creek in NE1/4 sec. 10, T. 29 N., R. $80 \mathrm{~W}$.

\section{SILICIFICATION OF SEDIMENTARY ROCKS}

At some places in the Shirley Basin the permeable rocks of several pre-Tertiary formations con- 
tain abnormally large amounts of siliceous cement. These indurated rocks are generally on topographically high areas that are now, or once were, only a short distance below the lowest beds of the White River Formation.

An example of intense silicification can be seen atop the hogback in secs. 14 and $24, T$. 27 N., R. $77 \mathrm{~W}$., where the lower, permeable sandstone of the Cloverly Formation has been silicified to such an extent that the Indians used it for making implements. Westward, down the dip slope of the hogback, the same beds grade into the normal well-cemented sandstone characteristic of the Cloverly Formation. On a small hill in the $\mathrm{N} 1 / 2$ sec. $28, \mathrm{~T} .28 \mathrm{~N}$, R. $77 \mathrm{~W}$., sandstone beds at the top of the Jelm Formation (or perhaps at the base of the Sundance) are so indurated by silica cement that positive identification is not possible. In contrast, these same beds at other places are poorly to moderately cemented sandstone. At some places in the northeastern part of the mapped area, the solution breccia on the old karst surface at the top of the Madison Limestone has been replaced and cemented with such large amounts of silica that it can be confused with one of the thick chert beds in the upper part of the Madison Limestone.

Silicified rock at or slightly above the base of the White River Formation and at the top of the Wagon Bed Formation is common in the Shirley Basin and has been described in the discussions of the lithology of these two formations. The silicification almost certainly resulted from leaching of silica from the tuffaceous rocks higher in the section, downward migration of the silica-bearing ground water, and deposition of silica at or near the base of the formation. It seems reasonable to assume that the same general process gave rise to the abnormally high silica content of the permeable rocks of pre-Tertiary age that closely underlie, or at some earlier time underlay, the White River Formation.

\section{STRUCTURE}

\section{LANDSLIDES}

Landslides of two ages have been differentiated on the geologic map of the Shirley Basin area. The older slides consist of large blocks of sandstone or shale that have slid on underlying claystone and have come to rest as far as half a mile laterally from their place of origin. Rocks of the Cloverly and Mowry Formations generally constitute the slide blocks. Some of the detached blocks are only slightly disturbed; others have been considerably broken and tilted. The older slides are found only in the eastern third of the Shirley Basin area.
Many of the slide blocks are partly buried by rocks of Tertiary age, and the undisturbed material upon which the slide rests is not exposed. Where the underlying rock is exposed, for example in sec. 20 , T. 28 N., R. 77 W., and sec. 24 , T. 27 N., R. 77 W., the material underlying the landslide debris is of pre-Tertiary age, generally rocks of the Morrison, Sundance, or Frontier Formations. This fact, the fact that the early Eocene was a time of moist climate, and the fact that relief in the Shirley Basin area was greatest just before deposition of the Wind River Formation all suggest that the landslides probably occurred in late Paleocene or earliest Eocene time. The slides are definitely pre-middle Eocene, as shown by the fact that debris from the slide blocks is incorporated in the lower part of the Wagon Bed Formation where it laps on and partly buries those blocks. Similar landslides were described by Gill (1962).

Landslides of Quaternary age, a few of which are now active, are present in many places in the Shirley Basin area. These young landslides are most common in the Bates Hole area, where gravitational forces and over-steepened slopes in rocks of the White River Formation and the Steele Shale have caused rock failure and sliding on a large scale. Quaternary slides are far less common in the central and eastern parts of the area, where they occur principally in rocks of Tertiary age. Slides in the Steele Shale are generally small but may affect as much as one-half square mile of surface area. Slides in the White River Formation are generally large, and masses of landslide debris covering a square mile or more of surface area are present along the steep eastern and western walls of Bates Hole. The larger landslide areas comprise many contiguous landslide blocks. A large landslide block on the west side of Bates Hole is shown in figure 21.

\section{FAULTS}

The Paleozoic, Mesozoic, and, to a lesser extent, the Tertiary rocks were affected by small-scale faulting. A prominent fault zone mapped (Harshman, $1968 \mathrm{~b}$ ) in secs. 13,23 , and $24, \mathrm{~T} .27 \mathrm{~N} ., \mathrm{R}$. 77 W., comprises a down-dropped block bounded by two high-angle normal faults and broken by several subsidiary parallel and transverse faults. Drag on the beds adjacent to one of the bounding faults indicates predominantly dip-slip movement which appears to have been 50-60 feet. These faults cut rocks ranging in age from Early Triassic (Red Peak Formation) to Early Cretaceous (Thermopolis Shale), and they are blanketed by rocks of early Eocene age (Wind River Formation). The faults 
appear to be of Laramide age. Gouge and breccia zones along the faults are minimal or absent. Some of the faults contain banded silica or silicified breccia, the float from which aids in locating the faults in areas of poor outcrops and thin soil cover.

In the east-central part of the mapped area, several small faults cut rocks of the lower part of the Goose Egg Formation (Permian), and in the northeast corner of the area, small faults displace Precambrian diabase dikes and fracture the Madison Limestone (Mississippian). Inasmuch as these faults do not extend into the adjacent or nearly adjacent rocks of Tertiary age, they too are considered to be of Laramide age.

In the Bates Hole area, where exposures are good and individual sedimentary beds have lateral continuity, a few small faults have displaced beds in the Miocene Arikaree Formation. These faults have steep dips, have displacements of 10-20 feet, and are of short strike length. However, in the Chalk Mountain area, 500-6,500 feet west of the west edge of the mapped area, two major high-angle normal(?) faults displace rocks of the Arikaree Formation 70-300 feet to form a graben. These faults can be traced laterally for 10,000-25,000 feet.

Faults are rare in the mine workings in the central part of the basin. None were noted in the Utah Construction and Mining Co. mine workings or in the Petrotomics Co. Section 9 pit. One fault having about 5 feet of displacement has been exposed in the Section 15 pit. In some exposures in the Petrotomics Co. pits, beds have been displaced by slumping on paleostream banks and by squeezing and flowage during diagenesis of the newly deposited sediments, but beds a few feet above and below the distorted rocks show no displacement. Sketchy data on the paleotopography of the preWind River erosion surface in the northeastern part of T. $27 \mathrm{~N}$., R. $79 \mathrm{~W}$., show an abrupt rise toward the west. The rise may have resulted from displacement along a Tertiary fault, but for lack of confirming surface and subsurface data, the feature has been considered to be erosional and is so shown on the geologic map of the area.

\section{FOLDS}

A syncline traverses the western part of the Shirley Basin area. The trace of the axis on the eroded surface of the Steele Shale, shown on the geologic map (Harshman, 1968b), is parallel to and about 10 miles west of the axis of the topographic basin. Rocks on the east limb of the syncline strike about N. $40^{\circ} \mathrm{W}$. and $\operatorname{dip} 2^{\circ}-12^{\circ} \mathrm{SW}$.; rocks on the west limb strike north or northwestward and dip $2^{\circ}-8^{\circ}$
E. Rocks of Tertiary age do not appear to have been folded, but because of poor exposures and irregular bedding in the Wind River Formation, it is impossible to state with certainty that the lowest Eocene rocks were entirely unaffected.

Attitudes observed in outcrops of Steele Shale in the Bates Hole area and along the south edge of the mapped area suggest that the fold is considerably tighter in the northern part of the area than in the southern part and that it plunges southward. It should be pointed out, however, that attitudes observed in Steele Shale may be misleading, owing to the instability of steep slopes in this formation and the expansiveness of the shale constituents.

In most of the Shirley Basin area the Tertiary rocks dip $1^{\circ}-2^{\circ} \mathrm{N}$. These dips reflect a slight northward tilt of the area since original deposition. At the extreme west edge of the mapped area, and for several miles westward, there is a gradual change in the dip of the Tertiary rocks from northeastward to northwestward and finally to southwestward. These changes resulted from collapse, in an area 1520 miles to the west, probably along major structures bounding the north flanks of the Shirley and Seminoe Mountains. The axis of this broad flat anticline in the Tertiary rocks lies several miles west of the mapped area. The fold is apparent in good exposures of conglomerate beds at the base of the upper member of the White River Formation in sec. 15, T. 28 N., R. 81 W. (fig. 22).

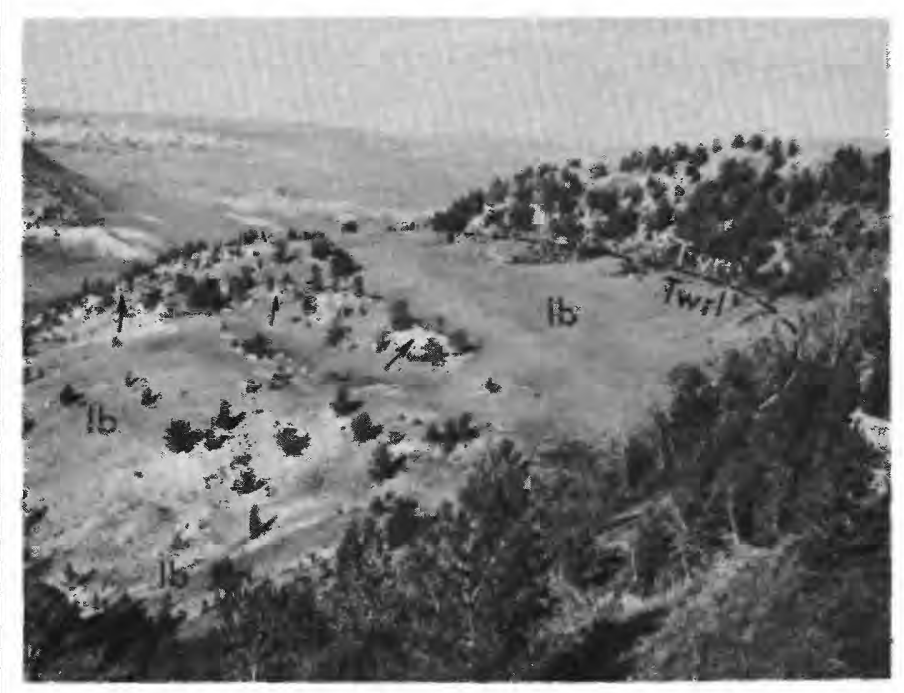

FIGURE 21. - Large landslide block (Ib) in the White River Formation on the west side of Bates Hole (sec. 13, T. 28 N., R. 81 W.). The contact between the upper (Twru) and lower (Twrl) members of the White River Formation lies just above and parallel to the upper edge of the slide. The large white blocks at the break in slope (indicated by arrows) are masses of conglomerate from upper member. 


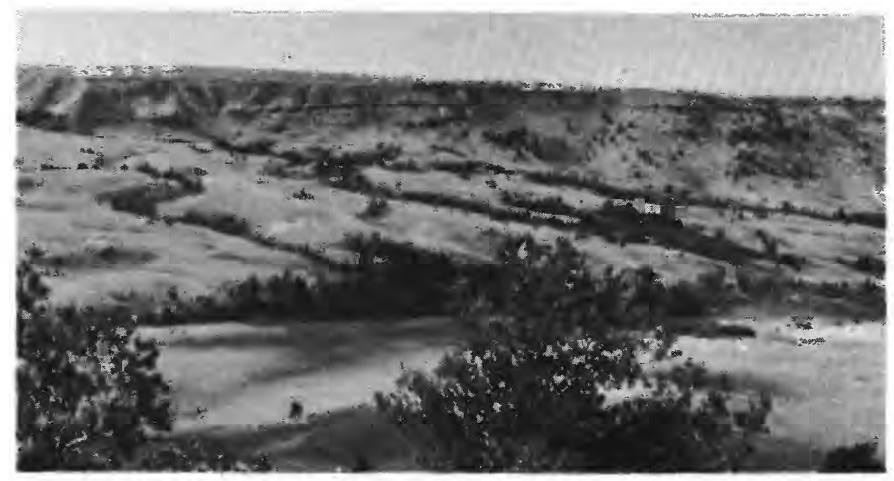

Figure 22. - Gentle fold in beds of conglomerate at the base of the upper member of the White River Formation, sec. 15, T. 28 N., R. 81 W., about 1 mile west of the west edge of the mapped area. Looking northwest.

\section{GROUND WATER}

Because ground water was believed to play an important part in the genesis of uranium deposits, in their subsequent modification, and, under certain conditions, in their ultimate destruction, studies were made to determine the hydrology and chemical nature of ground water now flowing in the Shirley Basin. These data are used in this report to speculate on the character of the ground water at the time the ore deposits formed.

Depths to ground water were measured in about 600 holes drilled in a 200-square-mile area of the Shirley Basin. Most of the measurements were made in the fall of 1959, before dewatering in preparation for mining had disturbed the normal ground-water regimen. All measurements were made with a device consisting of a reel, weighted probe, two-wire conductor, milliammeter, and battery power source. Depths were recorded to the nearest 0.5 foot. Surveyed collar altitudes were available for some of the holes, but most altitudes were taken from topographic maps, and they may be in error by as much as 5 feet.

Measurements of the depth to water were made in holes in which the water level was believed to have stabilized. Most depths were recorded in holes drilled a year prior to measurement; in more recently drilled holes, measurements were made at monthly intervals until consecutive readings were similar. To avoid false readings on surface water collected above a blocked section of hole, all holes were probed to make certain that they were open for several tens of feet below the water level. Measurements were made in the months June through September, a period of gradual rise of the ground-water table following the spring runoff. Utah Construction and Mining Có. records on observation wells in the southern part of T. 28 N., R. 78 W., show the annual fluctuations of the water table to be about 2 feet.

Ground water in the Shirley Basin is unconfined, and the water table, in a general way, reflects the surface topography. In the eastern part of the mapped area, where data on the ground water are available, there are three perennial streams. Two of them, the Little Medicine Bow River and the lower reach of Sand Creek, have cut below the main ground-water body, and they are gaining streams. The third, Spring Creek, is fed from and flows on a perched body of water. It is a gaining stream with respect to the perched water, but it may be a losing stream with respect to the main body of ground water. Contours on the main ground-water table, plotted on a topographic base, are shown in figure 23. The water table slopes southward at gradients of 20-30 feet per mile in the flat part of the basin and 100-150 feet per mile under the steep north rim.

Ground-water studies were made by the Utah Construction and Mining Co. for dewatering their mine and subsequently for the control of the solvent used in their solution mining process. These data show that: the upper and lower sandstone intervals, as well as most of the individual lenticular sandstone beds, are interconnected; perched water is present above some of the shale beds; in the area of study, ground water is moving south under a gradient of about 20 feet per mile; and some of the sandstone beds have permeabilities of as much as 1,000 meinzer units.

Water samples were collected from springs, pumped wells, and drill holes in the Shirley Basin area. Each sample was split between two 2-liter hard glass containers. One sample was treated with acetic acid and chloroform to keep uranium in solution and to prevent algal growth; the other sample was left untreated. Samples from drill holes were taken with a thief sampler suspended on a wire cable, and during the sampling process, small amounts of material from the drill-hole walls were dislodged and fell into the water. Suspended material introduced in this manner was removed by filtering at the sample site, before acidification, to minimize changes in the true chemical composition of the water sample. Temperature and $\mathrm{pH}$ measurements were made at the sample sites. A colorimeter using chlorophenol red, brom thymol blue, cresol red, and thymol blue dyes was used to determine $\mathrm{pH}$; probable accuracy was $0.1-0.2 \mathrm{pH}$ units.

The analytical results for 42 water samples, grouped according to the geologic formations from which the samples were taken, are shown in table 
2. The locations for 35 of the samples are shown in figure 23.

Average composition of water samples from the White River and Wind River Formations differs

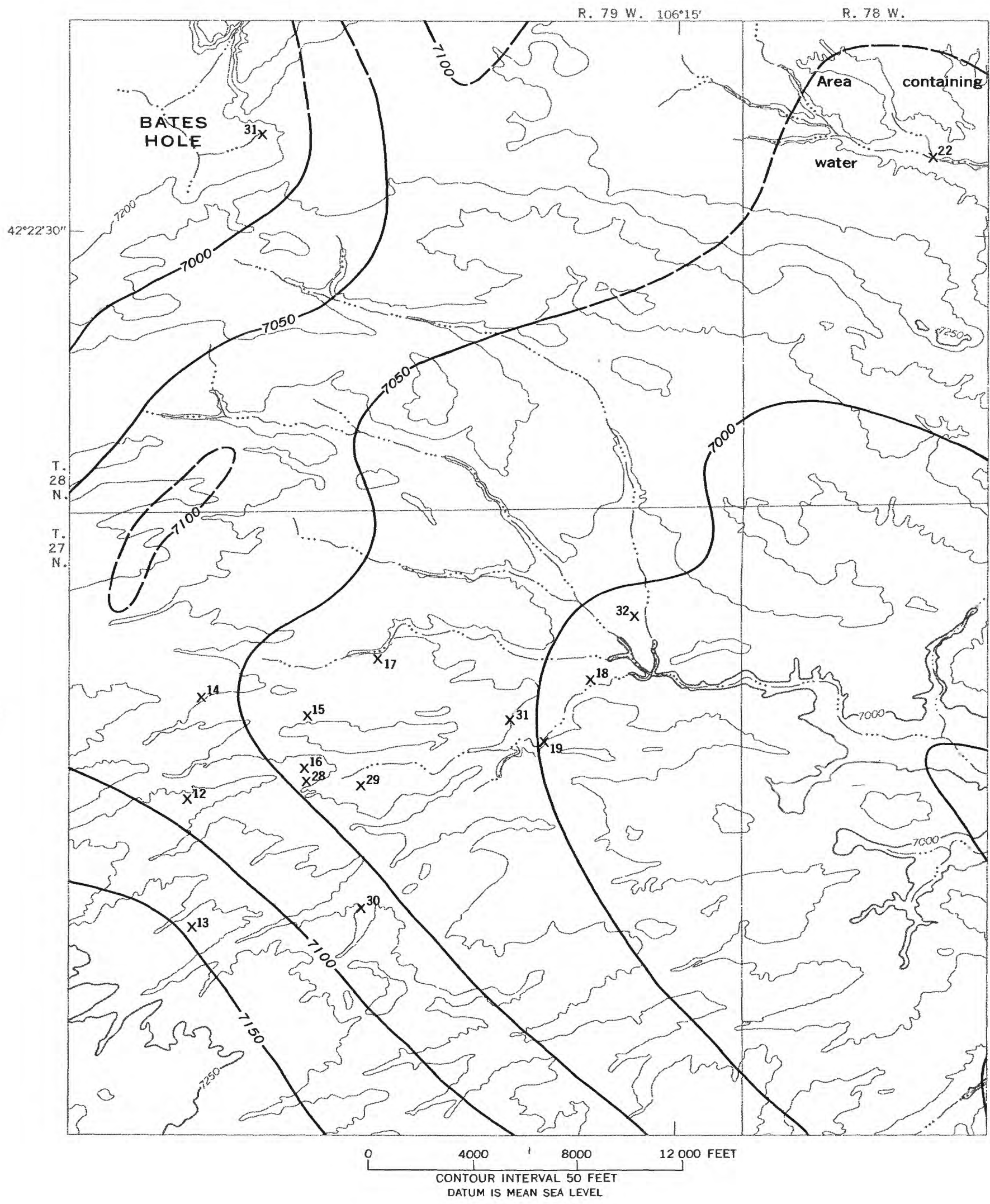


markedly. Water from the White River Formation of the calcium sodium bicarbonate type. The water is moderately hard, moderately mineralized, and from the Wind River is higher in silica and lower

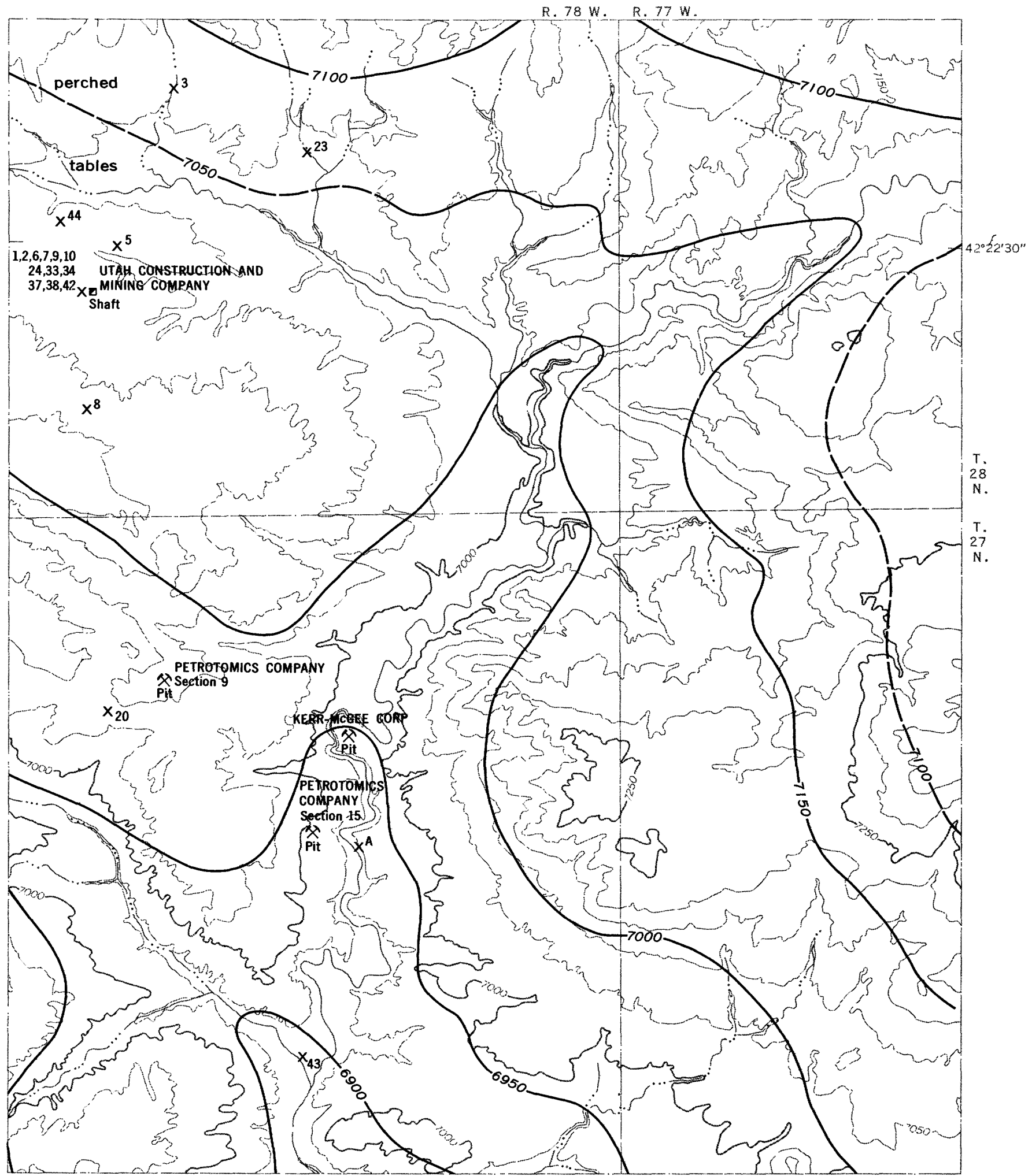

Figure 23. - Contours drawn on the top of the ground-water table for a part of the Shirley Basin, Carbon County. Dashed where approximate; interval is 50 feet. X, ground-water sample locality. Base modified from Harshman (1968b). 


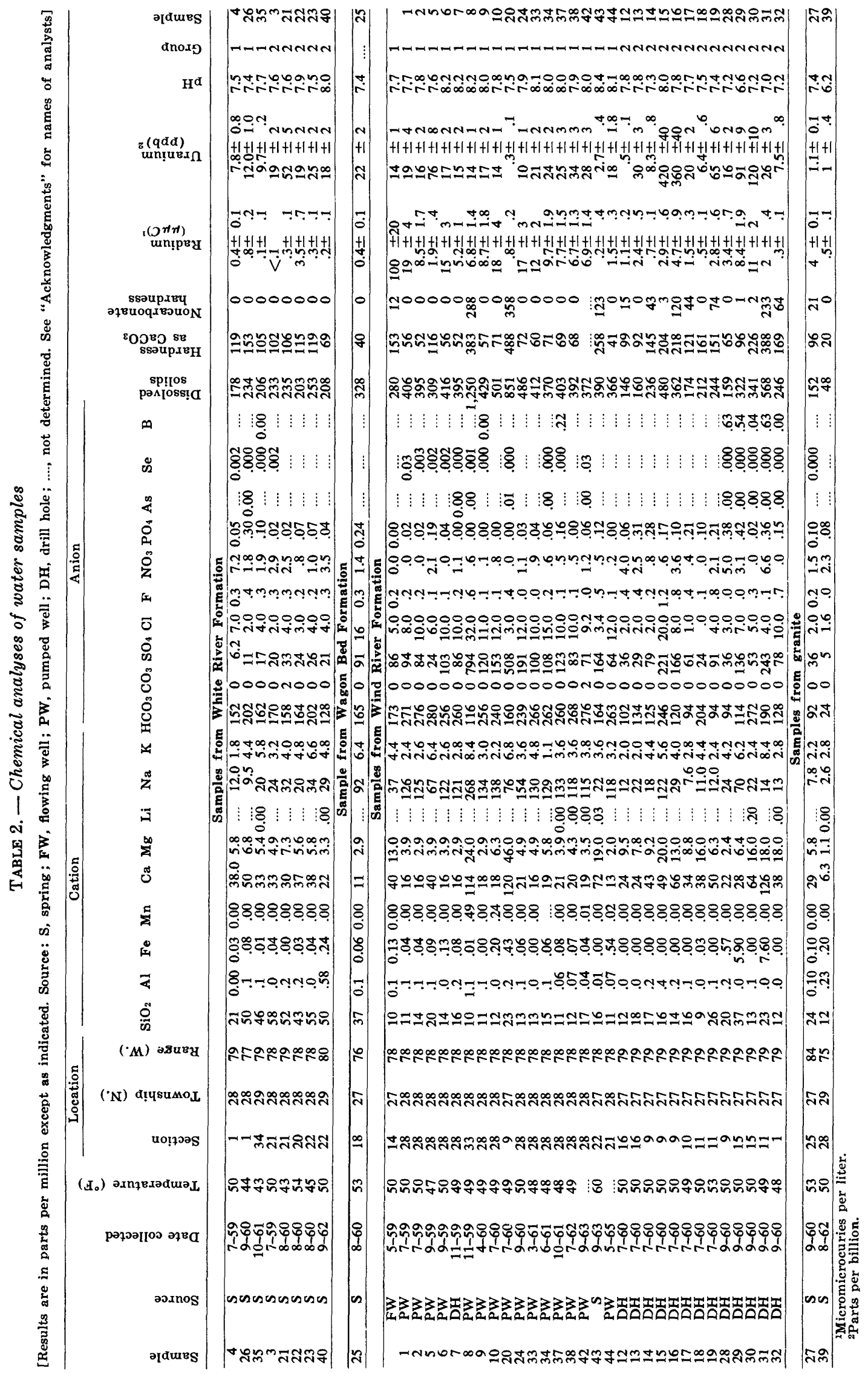


in magnesium, sodium, sulfate, chlorine, dissolved solids, noncarbonate hardness, radium, and uranium. The Wind River water is of the calcium sulfate and sodium bicarbonate type. It contains moderate amounts of dissolved solids and is moderately to very hard. The average $\mathrm{pH}$ of water from both the White River and the Wind River Formations is about 7.7. White River water samples in group 1 were taken near the base of the upper member; the samples in group 2 were taken near the base of the lower member. Water from the two members is similar, but that from the lower member contains more sodium, sulfate, and uranium and somewhat less phosphate than does that from the upper member.

Ground-water samples from the Wind River Formation are much less uniform in chemical composition than samples from the White River Formation. For example, in samples from the Wind River Formation, calcium ranges from 13 to $126 \mathrm{ppm}$ (parts per million), sodium from 7.6 to $268 \mathrm{ppm}$, bicarbonate from 94 to $280 \mathrm{ppm}$, sulfate from 24 to $508 \mathrm{ppm}$, and uranium from 0.3 to $420 \mathrm{ppb} ; \mathrm{pH}$ ranges from 6.6 to 8.4 . Water samples from the Wind River Formation have been grouped in table 2 according to the geologic environment from which they were taken. Group 1 samples were taken from the ore-bearing sandstone in the vicinity of large ore bodies and from 200-300 feet below the water table. They are similar in composition and contain calcium, sodium, bicarbonate, and sulfate as the principal constituents. Their average uranium content is the same as that in the water samples from the lower part of the White River Formation, but the radium content is greater by almost two orders of magnitude.

Group 2 samples were taken from exploratory drill holes in the western part of the Shirley Basin, where uranium ore lies near the base of the Wind River Formation and at or slightly below the ground-water table. The principal constituents of group 2 samples are the same as for group 1, but the amounts present range widely.

Ground-water samples from the White River Formation, groups 1 and 2, and from the Wind River Formation, group 1, appear to be in equilibrium with the geologic environments from which they were taken. Wind River samples, group 2, appear not to be similarly in equilibrium.

\section{ORE DEPOSITS}

Uranium is the only mineral commodity of major economic importance in the Shirley Basin area.
Large high-grade roll-type deposits occur in sandstone, and very small deposits occur in brecciated limestone in the karst surface at the top of the Madison Limestone. The Shirley Basin contains, in addition to uranium, deposits of monazite and construction materials.

\section{URANIUM DEPOSITS IN SANDSTONE}

The major uranium deposits in the Shirley Basin are in a well-defined belt of Wind River sandstone that was physically and chemically favorable for ore deposition. The belt extends for a distance of 6 miles northwestward through the central part of the area. The uranium deposits are in several sandstone intervals of the Wind River Formation of early Eocene age. They are roll-type deposits and lie at the margins of large tongues of altered sandstone (fig. 24) formed by the flow of ore-bearing solutions through the host rock. The tongues are irregular in plan and section, and areas of greatest irregularity generally contain the best ore deposits. Individual ore bodies contain from a few tons to several hundred thousand tons of ore; grades, as mined, range from 0.1 to 0.7 percent $\mathrm{U}_{3} \mathrm{O}_{8}$.

The principal ore mineral, uraninite, is either fine grained or sooty. It is associated with pyrite, marcasite, native (?) selenium, ferroselite, hematite, calcite, and organic material. The ore and associated minerals coat sand grains and fill interstices between grains.

West of the mineralized belt, exploratory drilling has shown deposits of large size and medium grade to be present in sandstone-filled channels in the old pre-Wind River erosion surface and in bedded sandstones close to the base of the Wind River Formation. The mineralogy of this ore may be similar to that of the ore in the main mineral belt, but at the time this report was prepared very few data were available on these deposits. They appear to be related to altered sandstone, but the nature of the relation is unclear, and the character of the alteration appears unlike that in the mineral belt to the east. Meager data from drill cuttings in secs. 35 and 36, T. 28 N., R. 79 W., secs. 1, 2, 3, 9, and 10, T. 27 N., R. 79 W., and secs. 1,2 , and 3, T. 27 N., R. 80 W., indicate that altered sandstone in this area contains considerable pyrite and that the feldspar in the arkose has been kaolinized. The milky-white color of the altered sandstone in this area contrasts with the greenish yellow color of the altered sand in the mineral belt to the east but is similar to altered sandstone described by King and Austin (1966) from the Gas Hills area and by Mrak 
(1968) in the Powder River Basin. Preliminary data indicate that disequilibrium may complicate ore-reserve estimates. These deposits are not discussed further in this report.

\section{PALEOTOPOGRAPHIC CONTROL}

The major ore deposits in the Shirley Basin overlie the lowest part of the pre-Wind River erosion surface (fig. 25). Most of the deposits lie west of a prominent ridge on the old surface, but a few lie east of breached or low areas in the ridge. The ridge is formed by the indurated Wall Creek Sandstone Member of the Frontier Formation of Late Cretaceous age. It ranges in height from about 400 feet near the north end of the mineral belt to about 100 feet near the south end, and it is buried beneath as much as 350 feet of Tertiary rocks. Southeast of the mineral belt the cover of Tertiary rocks has been removed by erosion, and the Wall Creek forms a prominent discontinuous ridge on the present surface.
The Wall Creek Sandstone Member separates the very soft, easily eroded shales of the Steele and Niobrara from the less easily eroded shales of the Frontier and Mowry. This difference in ease of erosion governed the configuration of the pre-Wind River erosion surface and the position of the lowest part of the basin. The paleotopography of the orebearing part of the Shirley Basin is shown by the red overprint on the geologic map of the area (Harshman, 1968b). The main or trunk stream that drained the area flowed northwestward, and it lay west of the ridge of the Wall Creek Sandstone Member. Major tributaries from both the east and the west joined the trunk stream in the area now containing the ore bodies. The presence of thick lignite beds interbedded with siltstone and cut by large crossbedded channel sandstone west of the ridge (fig. 26) indicates that the lowest part of the aggrading basin remained west of the ridge throughout much of Wind River time.

The coincidence of the lowest part of the basin and the favorable belt probably relates to the en-

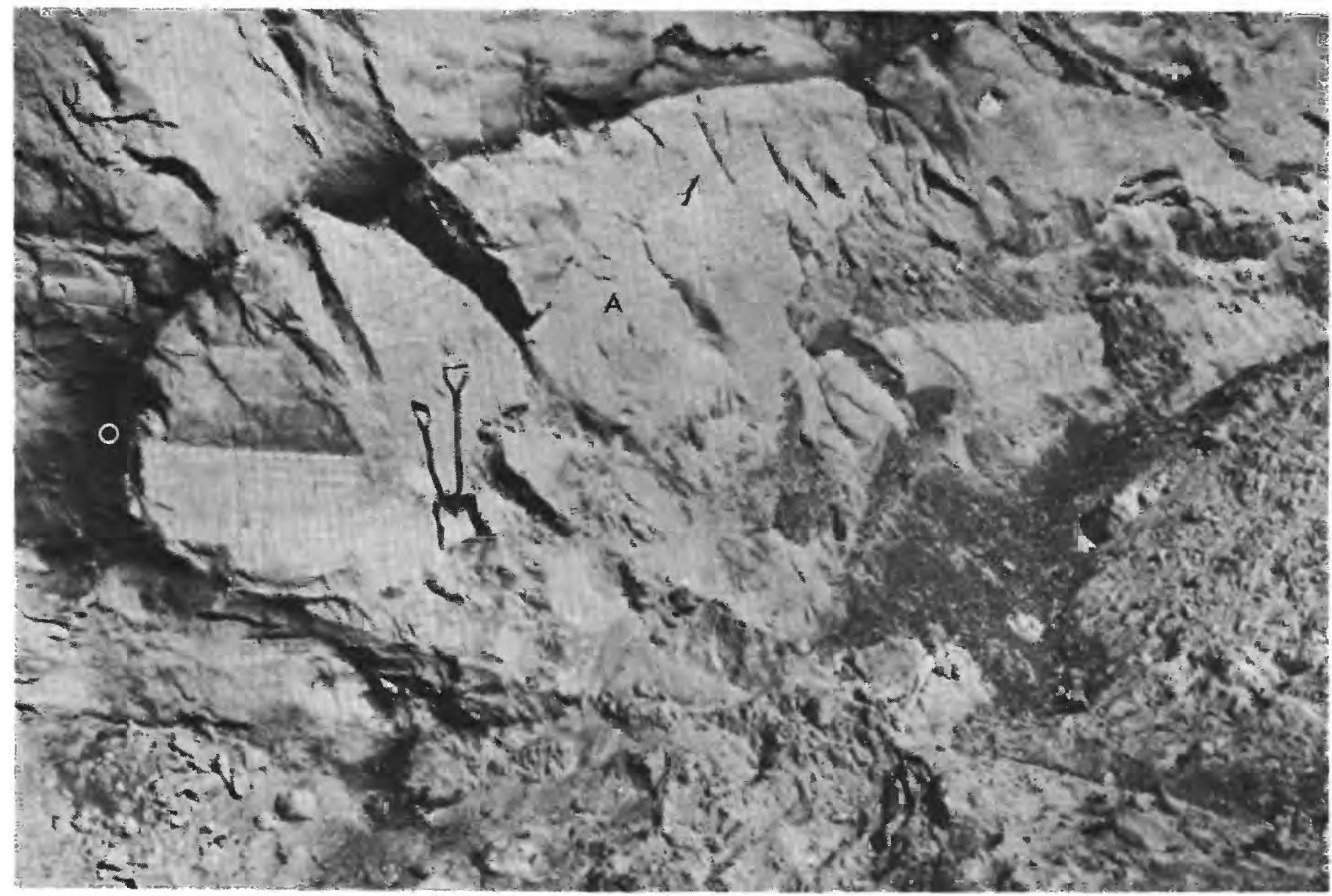

Figure 24. - Small roll on the upper surface of an altered-sandstone tongue in Wind River Formation in the Petrotomics Co. Section 9 pit. A, altered sandstone; U, unaltered sandstone; O, ore. Photograph by Emerson Kemp, Kerr-McGee Corp. 
vironment at the time the Wind River sediments Early in the depositional cycle, swampy flood-plain were being deposited west of the sandstone ridge. conditions developed along the trunk stream, and

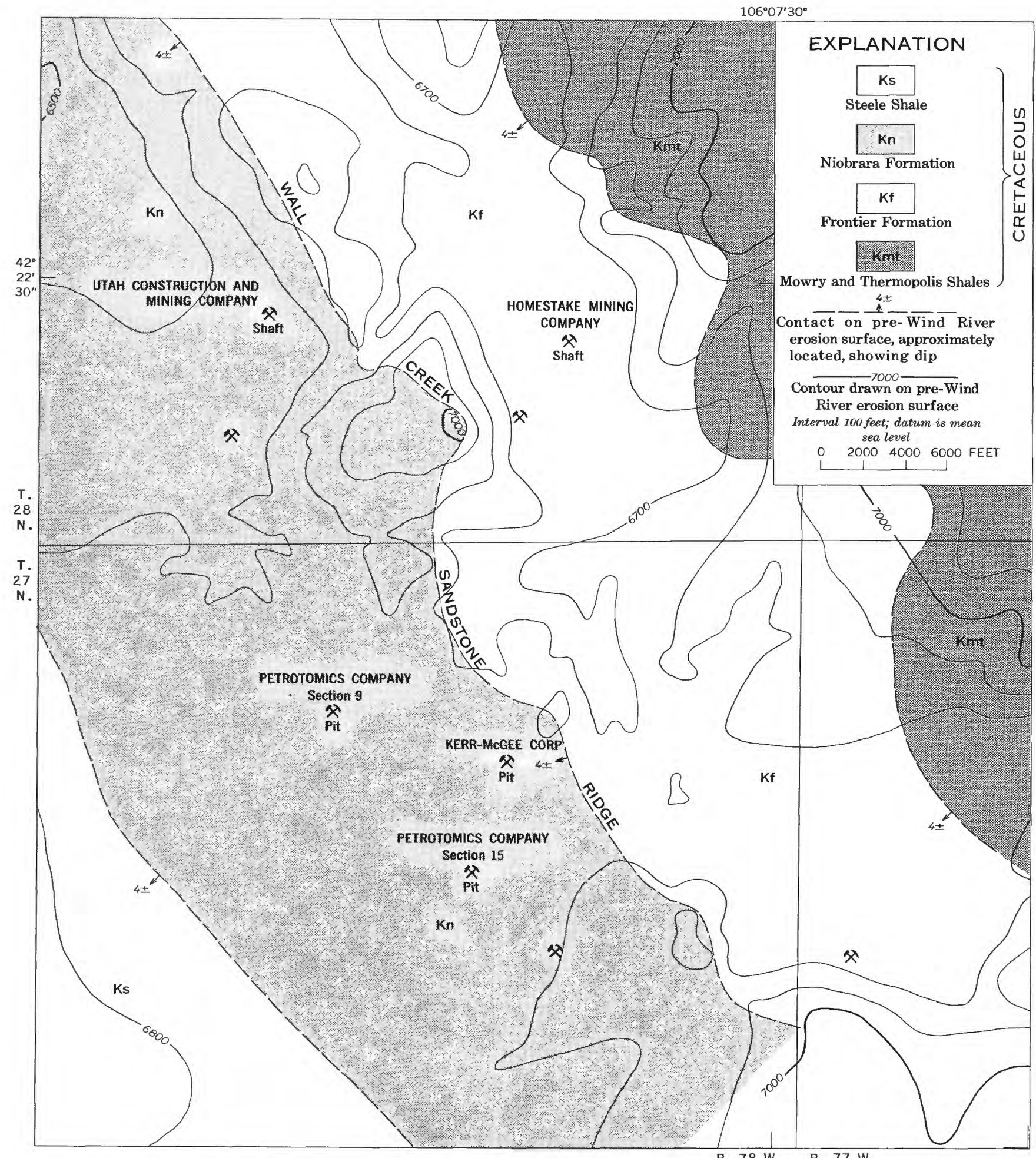

FIGURE 25. - Map of a part of the Shirley Basin showing paleogeology, paleotopography, and approximate locations of the principal ore deposits (pick-and-hammer symbol) with respect to the ridge of Wall Creek Sandstone Member, Frontier Formation. 
these conditions persisted through most of Wind River time. During periods of high water the tributary streams, flowing down the relatively steep slopes of the basin, carried considerable coarse clastic debris. Upon reaching the relatively flat flood-plain area in the lower part of the basin, this debris was deposited on and interbedded with the lignitic siltstone and lignite being deposited by the trunk stream. As a result of this depositional environment, strata in the lower part of the basin, just west of the ridge, consist of fine-grained siltstone and silty lignite interbedded with coarsegrained permeable channel sandstone-a rock sequence that was favorable for uranium deposition at a later time.

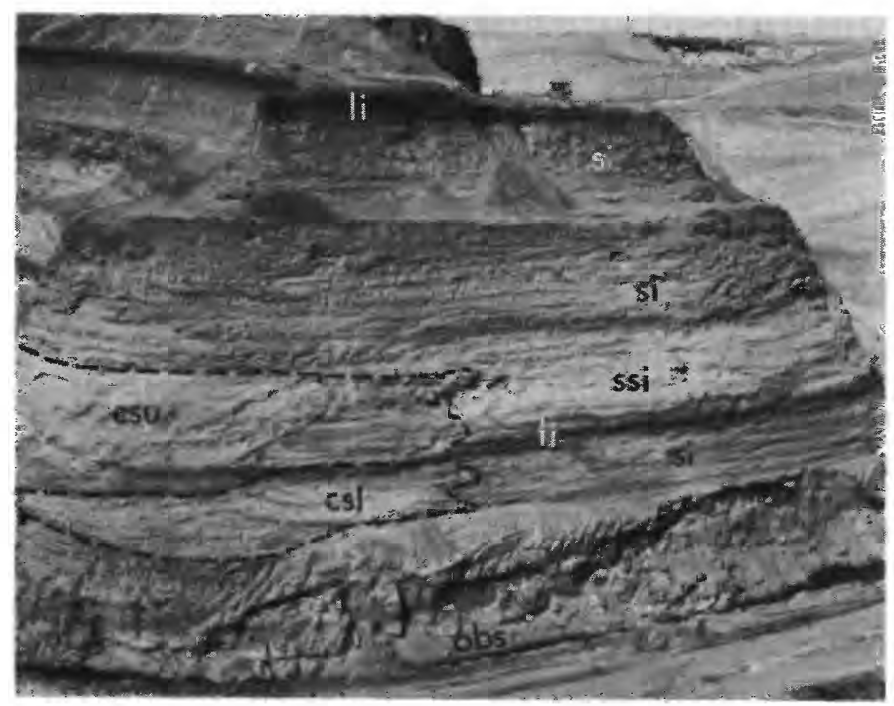

Figure 26. - Exposure in Petrotomics Co. Section 9 pit, showing a lower sandstone-filled channel (csl) cut in siltstone (si) and ore-bearing sandstone (obs); an upper sandstonefilled channel (csu) is cut in lignite (li), silty sandstone (ssi), and the lower channel sandstone (csl).

\section{RELATION TO ALTERED-SANDSTONE TONGUES}

The ore deposits in the mineral belt all lie at or near the margins of large tabular bodies of greenish-yellow altered ${ }^{1}$ sandstone. The outlines, in plan view, of the two principal altered tongues are shown in figure 27. The lower tongue is in a single sandstone interval that overlies the pre-Tertiary erosion surface. The upper tongue is in two sandstone intervals which in some places are separated by 30 40 feet of sandy siltstone and which in other places

\footnotetext{
"The term "altered" is used in the widely accepted sense to refer to those physical and chemical changes, excluding mineralization, effected by an orebearing solution on the rock through which it passed. "Unaltered" denotes a lack of such changes.
}

rest one on the other. The upper and lower altered tongues are separated by 50-75 feet of siltstone, lignitic siltstone, and silty claystone.

The upper altered tongue ranges in thickness from a few feet near its western edge to about 70 feet several thousand feet from the edge. The upper and lower surfaces are generally concordant with the low dip of the Wind River Formation, but in many places the contact between altered and unaltered sandstone or altered sandstone and ore cuts sharply across sedimentary structures. The upper altered-sandstone tongue is 5 miles long in a northwesterly direction and as much as 3 miles wide. At one time it may have been somewhat longer, but south of the Petrotomics Co. Section 9 pit the tongue passes into the zone of recent weathering, and is obliterated. The upper altered tongue is about 90 150 feet below the surface in the Petrotomics Co. Section 9 pit, 350 feet deep in the Utah Construction and Mining Co. section 28 mine, and 450 feet deep 2 miles farther north in sec. 20 , T. 28 N., R. 78 W. The western edge of the tongue drops about 325 feet in altitude in a distance of $41 / 2$ miles and thus plunges northwestward about 70 feet per mile.

The lower tongue has recently been exposed by mining operations in sec. 15, T. 27 N., R. 78 W., and in most aspects it is similar to the upper one. It lies beneath the southeastern part of the upper tongue but does not extend as far to the northwest. Drilling in secs. 15 and 16, T. 27 N., R. 78 W., about 2 miles south of the Petrotomics Co. Section 9 pit, shows that the siltstone and silty claystone beds that separate the upper and lower sandstone intervals reach the ground surface in that area, and that to the south the upper sandstone tongue has been eroded.

Both of the altered-sandstone tongues end abruptly on their southwest sides. Near the western edges of the tongues there is no apparent difference in the permeabilities of the altered and unaltered sandstone, and it is probable that the limits of alteration were governed by chemical rather than physical changes in the host rock. In sharp contrast, the altered-sandstone tongues gradually fade out eastward along an irregular indistinct zone of decreasing permeability in the unaltered sandstone; therefore, the termination of the tongues eastward seems to result from physical as well as chemical changes in the host sandstone. For a short distance north from the Utah Construction and Mining Co. property, the eastern edge of the upper altered-sandstone tongue and the sandstone bed in which the tongue formed abut the buried ridge of Cretaceous rocks discussed earlier in this report. There is no 
ore at the contact of the altered sandstone and the Cretaceous shale and sandstone.
Factors controlling the geographic positions of the altered-sandstone tongues in the Shirley Basin

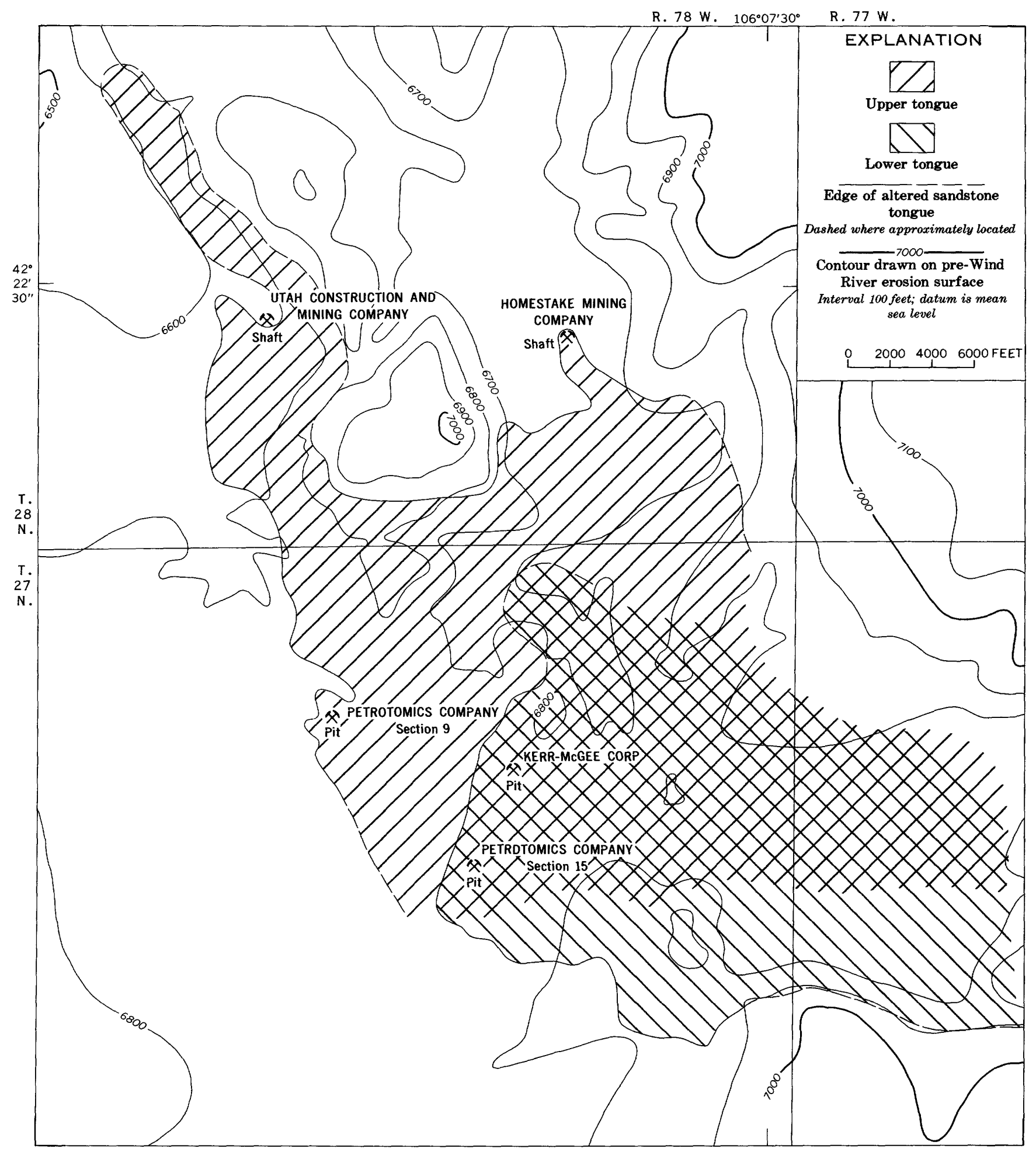

Figure 27. - Map showing relation of altered-sandstone tongues to paleotopography and the location of principal mines at edges of altered-sandstone tongues. 
are not known, but possibly these tongues are related spatially to major streams that drained the west flank of the Laramie Mountains in Eocene time. Both tongues plotted in figure 27 extend to, and span, the mouth of a major valley in the preWind River erosion surface. Paleocontours and reconnaissance mapping east of the Shirley Basin project area indicate that the valley was formed by a major stream that extended at least 15 miles east of the center of the Shirley Basin (Denson and Harshman, 1969). The character of the sediment carried by this major tributary stream and deposited at, and downstream from, its confluence with the trunk stream may have been one of the factors that controlled the position of the altered tongues. However, a more important factor may have been the fact that the downward- and laterally migrating uranium-bearing ground water moved more easily through the material filling this major stream channel than through the material in which the channel was cut.

Alteration is generally limited to the highly transmissive thick sandstone intervals of the Wind River Formation. The effect of the permeability (a coefficient that is independent of thickness) of any particular bed on the configuration and position of the altered tongue is difficult to assess. Twentythree samples of sandstone (seven unaltered, two ore-bearing, and 14 altered) were selected for study to determine if size analyses would indicate differences in the permeabilities of the three sample groups. Table 3 summarizes the size-frequency data of the samples after separation on a standard set of screens of decreasing class interval $\sqrt[4]{2}$ (ASTM

TABLE 3. - Size-frequency data on 23 samples of altered, orebearing, and unaltered sandstone

[Data computed according to methods described by Pettijohn (1957, p. \begin{tabular}{lllll}
\multicolumn{4}{c}{$35-38)$. Grain size, in millimeters] } \\
${$\cline { 5 - 6 }$}$ Mode $\quad$ Median $}$ & Sorting, Skewness, & Kurtosis,
\end{tabular}

\begin{tabular}{|c|c|c|c|c|c|}
\hline & & & $\sqrt{Q_{3} / Q_{1}}$ & $Q_{1} \cdot Q_{3} / M d^{2}$ & $\left(Q_{3}-Q_{1}\right) / 2\left(P_{90}-P_{10}\right)$ \\
\hline \multicolumn{6}{|c|}{ Unaltered sandstone } \\
\hline & 0.33 & 0.42 & 1.32 & 1.02 & 0.203 \\
\hline 305 & .42 & .46 & 1.31 & 0.99 & .212 \\
\hline 306 & .46 & .48 & 1.31 & .97 & .206 \\
\hline 307 & .44 & .48 & 1.36 & .93 & .188 \\
\hline 308 & .46 & .51 & 1.36 & .93 & .207 \\
\hline 309 & .48 & .48 & 1.38 & .96 & .201 \\
\hline 310 & .55 & .39 & 1.93 & .79 & .199 \\
\hline \multicolumn{6}{|c|}{ Ore-bearing sandstone } \\
\hline 312 & 0.59 & 0.64 & 1.44 & 1.02 & 0.186 \\
\hline 316 & .57 & .59 & 1.47 & .94 & .237 \\
\hline \multicolumn{6}{|c|}{ Altered sandstone } \\
\hline 324 & 0.57 & 0.54 & 1.35 & 0.90 & 0.168 \\
\hline 329 & .57 & .55 & 1.53 & 1.00 & .250 \\
\hline 333 & .57 & .55 & 1.37 & .94 & .179 \\
\hline 336 & .59 & .65 & 1.58 & 1.15 & .236 \\
\hline 341 & .35 & .40 & 1.52 & .98 & .227 \\
\hline 344 & .50 & .44 & 1.46 & .99 & .213 \\
\hline 348 & .35 & .40 & 1.83 & 1.03 & .240 \\
\hline 349 & .46 & .44 & 1.46 & .99 & .207 \\
\hline 350 & .33 & .43 & 1.46 & .97 & .212 \\
\hline 351 & .55 & .54 & 1.46 & .84 & .209 \\
\hline 352 & .54 & .46 & 1.50 & .83 & .246 \\
\hline 353 & .35 & .42 & 1.48 & .90 & .222 \\
\hline 354 & .35 & .40 & 1.52 & .91 & .220 \\
\hline 355 & .33 & .40 & 1.41 & .91 & .245 \\
\hline
\end{tabular}

sieve scale). Figure 28 shows typical frequency and cumulative distribution curves for the three groups of the samples. Unaltered, altered, and ore-bearing sandstones are similar in their principal physical parameters. The sandstones are well sorted, slightly skewed toward the fine sizes, and moderately peaked. Although these data indicate no significant difference between altered and unaltered sandstone, it is probable that gross permeability, not the permeability of any small segment of the sandstone interval, controlled the position of the tongues.

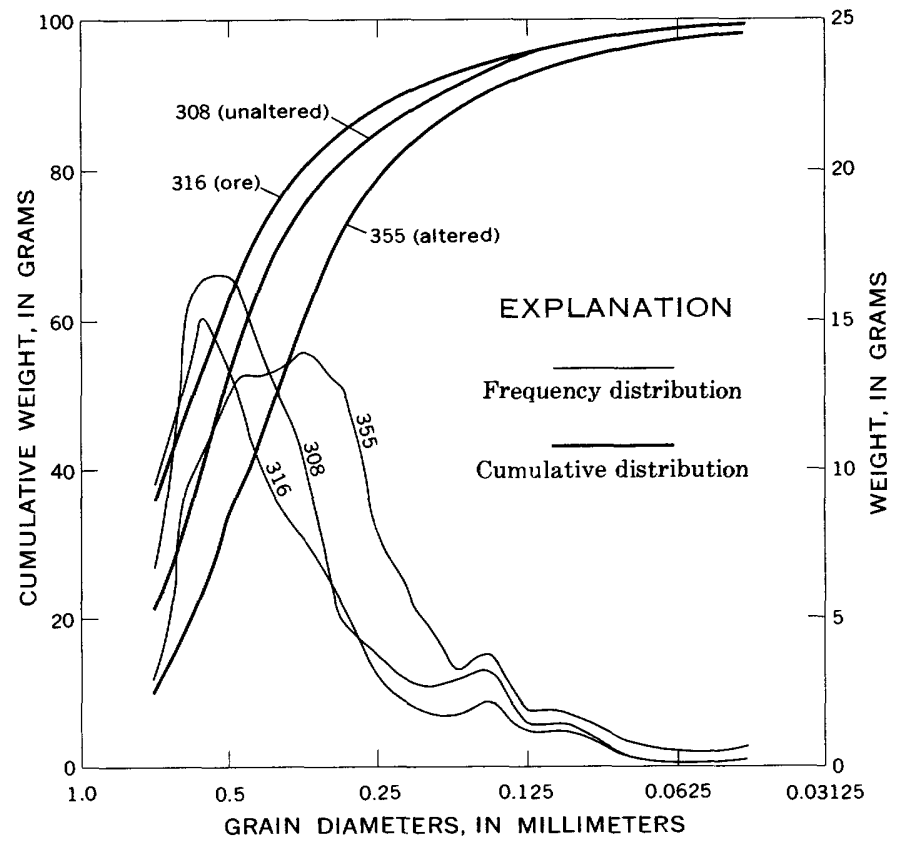

Figure 28. - Cumulative and frequency distributions of three samples of sandstone from the ore-bearing sandstone interval, Petrotomics Co. Section 9 pit.

\section{CHARACTER OF ALTERATION}

Color is the most striking difference between altered and unaltered sandstone. This color difference is well illustrated in the frontispiece photograph. In some exposures the color contrast is strong and easily recognized, in others it is subtle and can be seen only in sandstone containing considerable silty material. Unaltered sandstone, where unweathered, is generally medium to light gray. Altered sandstone is generally greenish yellow, although in some areas it is orange, red, or reddish brown. When samples of gray unaltered sandstone and greenish-yellow altered sandstone are screened, silt and clay retain the diagnostic color. The minus200 -mesh, or $0.074-\mathrm{mm}$ (millimeter), fraction of a sample of altered sandstone constitutes only 3.3 percent of the sample, but this fraction contains 
about 36 percent of the iron in the bulk sample. In sharp contrast, the minus-200-mesh fraction of unaltered sandstone contains only 12 percent of the iron in the bulk sample. X-ray analyses of the iractions of altered sandstone smaller than $0.002 \mathrm{~mm}$ in diameter show these materials to be montmorillonite that is high in iron; the same size fractions of unaltered sandstone are montmorillonite that is low in iron. These data suggest that the color distinctions between altered and unaltered sandstone are a result of the amount and oxidation state of iron in the fine-grained fractions of the rocks.

To determine the changes in the sandstone which were due to alteration by the ore-bearing solutions, 39 samples of sandstone were tested for the relative amounts of clay, silt, and sand (by weight), the content of acid-soluble material (by weight), and the principal heavy minerals (by weight and by grain count). The data from the study are in table 4. The heavy minerals were separated in bromoform, and the heavy-mineral percentages were determined by counts on mineral grains ranging from 0.044 to $0.250 \mathrm{~mm}$ in diameter. Depending on the shape, diameter, and specific gravity of the grains, the amount of any mineral may differ considerably from the grain count. For example, in samples 214 and 215 the percentages (by grain count) of hornblende and epidote are about equal, but because most of the epidote is in large spherical grains and most of the hornblende is in small tabular grains, the amount (by volume) of epidote in the sample is at least three times that of hornblende.

The black opaque mineral contents of ore, altered sandstone, and unaltered sandstone shown in table 4 are not directly comparable. Uraninite, absent in altered and unaltered sandstone, is present with other black opaque minerals of the ore samples. An estimate of the sedimentary (syngenetic) black opaque minerals for each ore sample is shown in parentheses in the table.

TABLE 4. - Physical and mineralogical data on 39 samples of unaltered, altered, and ore-bearing sandstone

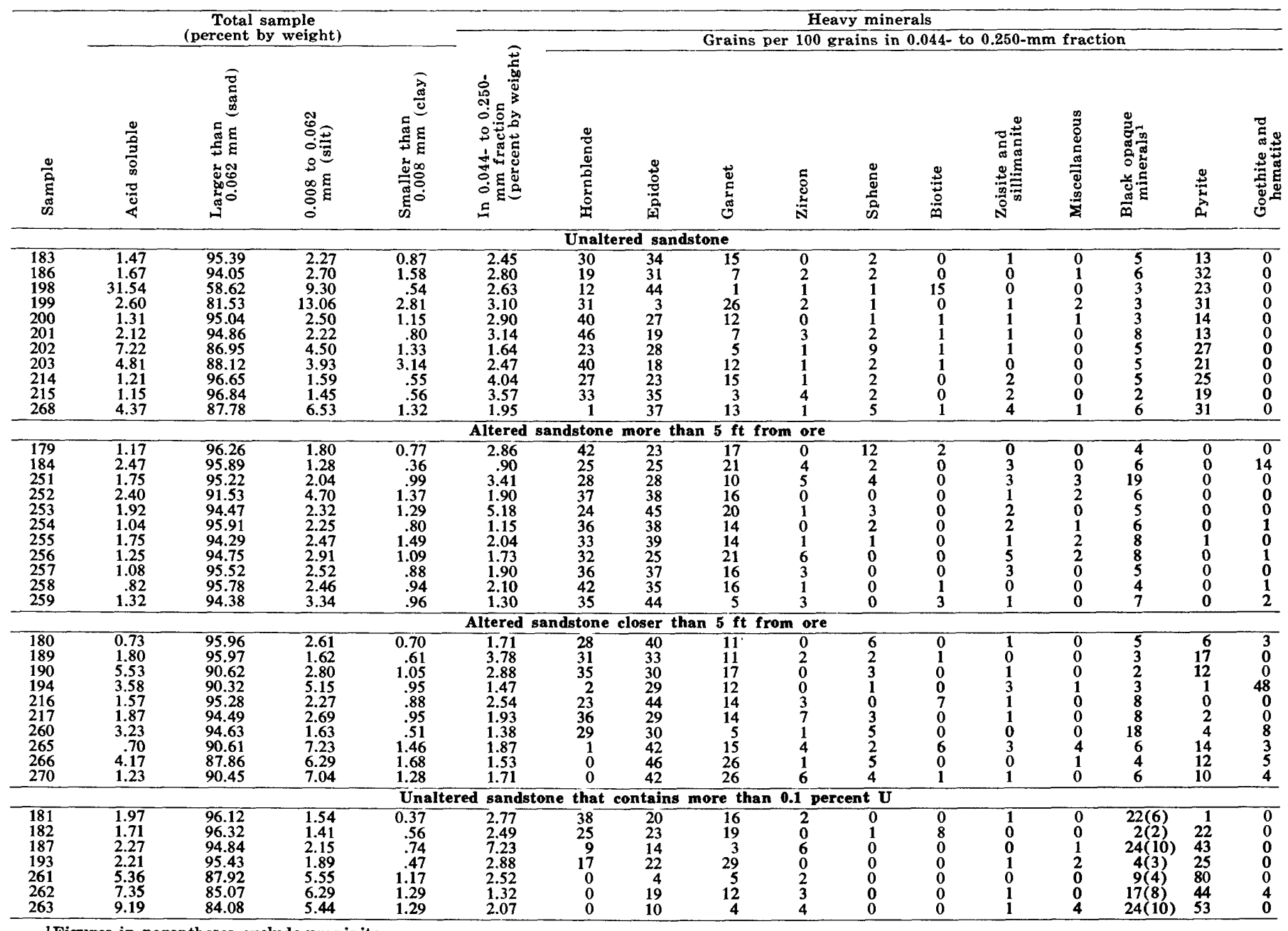

${ }^{1}$ Figures in parentheses exclude uraninite. 
Table 4 quantifies some of the differences between altered and unaltered sandstone observed in the field. Pyrite, present in unaltered sandstone in significant amounts, has been largely destroyed in the altered sandstone, and it has been deposited with uranium in the ore bodies. Pyrite constitutes about 23 percent (by grain count) of the heavy-mineral suite in unaltered sandstone, 38 percent in ore-bearing sandstone, 8 percent in altered sandstone within 5 feet of ore, and only 0.9 percent in altered sandstone more than 5 feet from ore. Chemical analyses for sulfide sulfur, run on about 200 samples of ore and host rock, confirm the conclusions based on heavy-mineral counts and show that sulfide minerals (pyrite and minor amounts of marcasite are the only known sulfide minerals associated with ore) constitute 0.19-2.75 percent (by weight) of the unaltered sandstone, $0.20-17.60$ percent of ore, 0.040.77 percent of altered sandstone near ore, and 0.02 0.04 percent of the sandstone more than 5 feet from ore.

Early work in the Shirley Basin (Harshman, 1962) suggested that the black opaque minerals in the altered sandstone had been partly destroyed by the ore-bearing solutions. Subsequent work has shown this to be untrue. Data in table 4 indicate that the black opaque minerals from altered and unaltered sandstone are similar, and that they constitute 4.5-7.0 percent of the heavy-mineral concentrate. Magnetite is present in each of the samples. The weight percent of heavy minerals in the unaltered sandstone is greater than in the altered sandstone (2.8 versus 2.2 and 2.1 percent), but this reflects differences in pyrite, not differences in the black opaque mineral contents.

Alteration by ore-bearing solutions, particularly acid ones, generally produces fine-grained material, so alteration in the Shirley Basin might have resulted in an increase in the clay content of the sandstone. The first indication that this was not the case came when clay-sized particles (less than $0.002 \mathrm{~mm}$ in diameter) were separated from altered- and unaltered-sandstone samples for identification of the clay minerals in the two rocks. Almost without exception, the amount of clay obtained from 500 -gram samples of altered sandstone was slightly less than that obtained from equal weights of unaltered sandstone. Size analyses of the 39 samples listed in table 4 show that unaltered sandstone contains an average of 1.33 percent by weight of particles less than $0.008 \mathrm{~mm}$ in diameter (clay and very fine grained silt), and that altered sandstone contains only 1.00 percent of the same sized particles. Comparable data from the samples listed in table 3 show that particles less than $0.044 \mathrm{~mm}$ in diameter comprise 1.47 percent of unaltered sandstone and 1.08 percent of altered sandstone. These data suggest that alteration decreased the amount of finegrained material in the rock, but the apparent decrease may have resulted from inadequate sampling. It seems certain, however, that alteration did not result in an increase in the amount of very fine grained constituents in the sandstone.

Destruction of much of the calcium carbonate in altered sandstone is apparent in exposures near the margins of the altered tongues. It is confirmed by the contents of acid-soluble constituents listed in table 4 and by analyses for mineral carbon in about 100 samples taken in ore and host rocks. Acidsoluble constituents comprise 2.79 percent of the unaltered sandstone (sample 198, table 4, omitted in calculating this average), 2.44 percent of the altered sandstone near ore, and 1.54 percent of the altered sandstone more than 5 feet from ore. Analyses for mineral carbon, converted to $\mathrm{CaCO}_{3}$, show that calcium carbonate constitutes 2.25 percent of the unaltered sandstone, 2.00 percent of the altered sandstone near ore, and 0.15 percent of the altered sandstone several tens of feet from ore. Analyses for acid-soluble constituents and for mineral carbon were made on different suites of samples and are therefore not directly comparable. Because calcite is generally in concretions rather than distributed throughout the rocks, few sandstone beds contain calcium carbonate in amounts approaching the averages given above.

Field and laboratory evidence shows that carbonaceous material, common in the Wind River Formation throughout the lower part of the Shirley Basin, has been almost completely destroyed in the alteredsandstone tongues. Figure 29 is a photograph taken in the Petrotomics Co. Section 9 pit where a vertical cut exposed the contact between altered and unaltered sandstone along the lower surface of an altered tongue. The photograph shows considerable dark carbonaceous trash in crossbedded unaltered sandstone below the contact; the amount of trash decreases rapidly on the same crossbeds in the 6to 8-inch interval in altered sand above the contact, and at a point about 1 foot above the contact the trash has been completely destroyed. Carbonaceous material in unaltered sandstone is generally vitreous and shows the structure of the woody material from which it was derived. In marked contrast, the carbonaceous material in altered sandstone near the contact is generally sooty and shows no relict structure. Carbonaceous material at the contact, or in altered sandstone very near the contact, may have 
a vitreous core and an altered sooty shell. Within the altered-sandstone tongue, at distances of more than 10 feet from the edges, carbonaceous material is rare, and where found, it generally consists of small sooty nodules containing considerable silt and clay.

Chemical analyses confirm the field evidence that alteration destroyed carbonaceous material once present in the sandstone. Because of its erratic distribution, the organic-carbon content of unaltered sandstone ranges between wide limits, but most samples contain a few tenths of a percent and a few contain as much as 2 percent organic carbon. The organic carbon content of altered sandstone, on the other hand, is generally less than 0.10 percent near the margins of the tongues and less than 0.02 percent a few feet from the margins.

The $\mathrm{Fe}^{+2} / \mathrm{Fe}^{+3}$ ratios in the sandstone host rocks changed considerably during the ore-forming process. Analyses of samples from three roll-type ore bodies, two in the Petrotomics Co. Section 9 pit and one in the underground mine of the Utah Construction and Mining Co., show that unaltered sandstone, presumably unaffected by the ore-bearing solutions, has a $\mathrm{Fe}^{+2} / \mathrm{Fe}^{+3}$ ratio ranging from about $2.0: 1$ to $4.5: 1$. In marked contrast, the altered sandstone more than 5 feet from ore has a ratio ranging from about $1.5: 1$ to less than $0.4: 1$ and generally less than $1: 1$. The total-iron contents of altered and unaltered sandstone are approximately the same. The ore contains much more total iron than does either the altered or the unaltered sandstone. $\mathrm{Fe}^{+2} / \mathrm{Fe}^{+3}$ ratios in ore range from about $4.5: 1$ to more than 100:1 and reflect the large amount of pyrite deposited with uranium in the ore bodies.

A marked difference in selenium content distinguishes altered from unaltered sandstone. Several hundred samples of unaltered, unmineralized sandstone from the ore-bearing intervals and from strata in the pit walls above those intervals were analyzed turbidimetrically for selenium. They contain $0.5-4 \mathrm{ppm}$ selenium. The higher amounts are

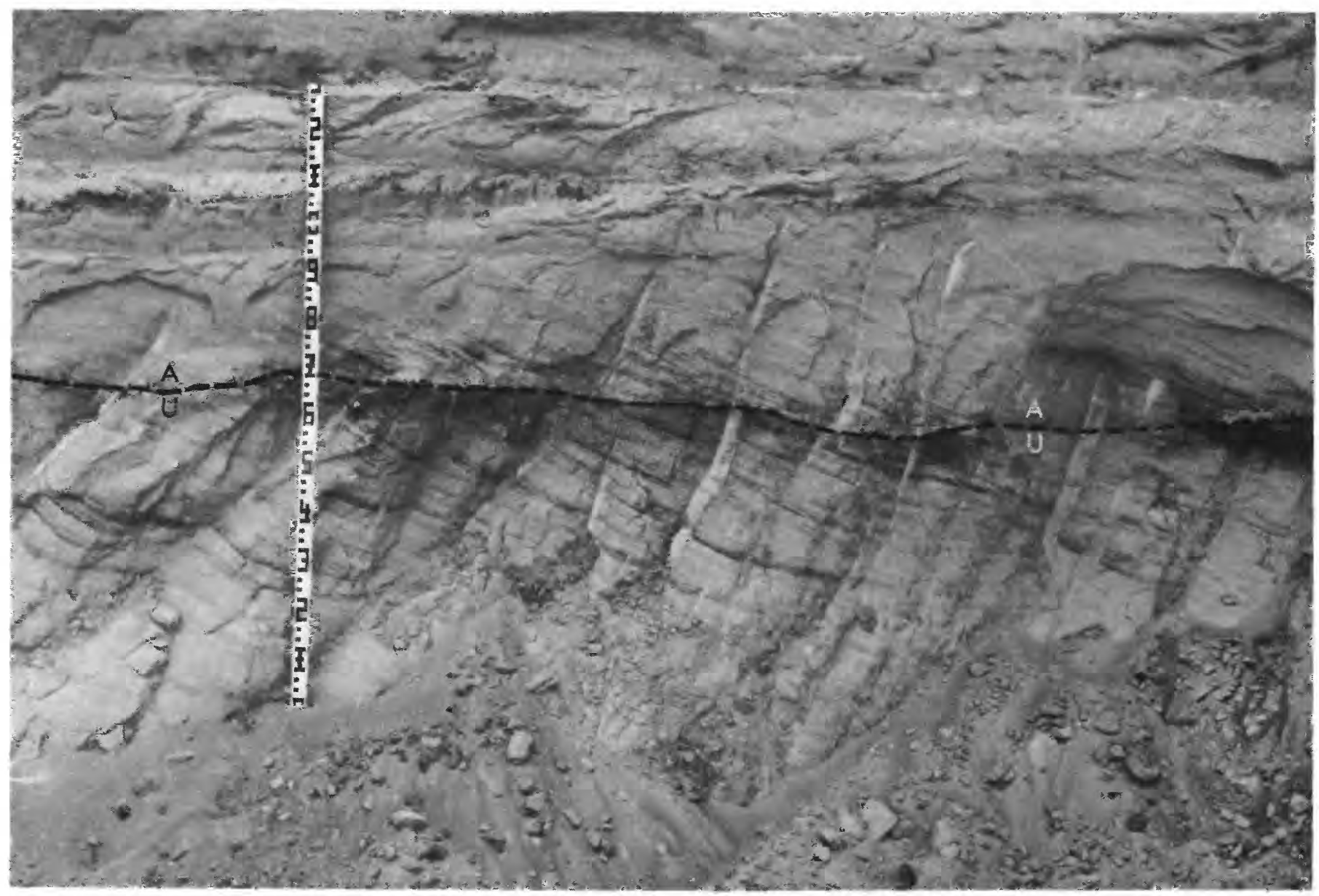

Figure 29. - Vertical exposure in Petrotomics Co. Section 9 pit, showing contact (dashed) between altered (A) and unaltered (U) sandstone on lower surface of altered-sandstone tongue. Dark streaks in unaltered sandstone are carbonaceous materials on crossbeds. 
generally in the fine-grained carbonaceous rocks; the lower amounts are in the sandstone and conglomerate. The nature of the selenium in these rocks is unknown; it may be in the native state. In altered sandstone a few feet or more from the edges of the altered tongues, selenium constitutes $10-40 \mathrm{ppm}$ of the altered rock, and thus is about 1 order of magnitude more abundant than in unaltered sandstone. Inasmuch as selenium forms relatively insoluble compounds with iron, this selenium probably is associated with limonite and goethite, common in the altered sandstone. High concentrations of selenium at the margins of the altered-sandstone tongues and in the ore are described in the discussion of mineralogy and mineral distribution.

There is some evidence that copper has been leached from the altered-sandstone tongues. Analyses on one suite of samples from the Petrotomics Co. Section 9 pit show that altered sandstone contains an average of $3 \mathrm{ppm}$ copper (range, 1-7 $\mathrm{ppm}$ ) and that unaltered sandstone contains 10 ppm (range, $2-15 \mathrm{ppm}$ ). However, two other sample suites, one from the Petrotomics Co. Section 9 pit and the other from the Utah Construction and Mining Co. mine, show little difference in the copper content of altered and unaltered sandstone.

Table 5 summarizes the principal differences between altered and unaltered sandstone in the Shirley Basin.

TABLE 5. - Principal differences between altered and unaltered sandstone

\begin{tabular}{|c|c|}
\hline Altered sandstone & Unaltered sandstone \\
\hline $\begin{array}{c}\text { Color } \\
\text { Greenish yellow, } \\
\text { orange, red. }\end{array}$ & \\
\hline $\begin{array}{l}\text { Montmorillonite } \\
\text { Pyrite }\end{array}$ & \\
\hline $\begin{array}{l}\text { Calcite } \\
\text { Carbonaceous material } \\
\text { Copper } \\
\mathrm{Fe}^{+2} / \mathbf{F e} \mathrm{e}^{+3} \\
\text { Selenium }\end{array}$ & $\begin{array}{l}\text { Do. } \\
\text { Do. } \\
\text { Present in small amounts. } \\
1 \text { ppm or less. }\end{array}$ \\
\hline
\end{tabular}

THE ORE BODIES

PHYSICAL CHARACTER

The major ore bodies in the Shirley Basin are at the edges of the altered-sandstone tongues in zones that separate altered from unaltered sandstone. Their inner contacts with altered sandstone are generally sharp, and their outer contacts with unaltered sandstone are gradational. An ore body, in its simple form, is crescent shaped in section, and in plan it is elongate parallel to the margin of the altered tongue. Ore boundaries generally cut bedding of the host rock at steep angles, although the horns of the crescent may be peneconcordant with the bedding. Fischer (1942) used the term "roll" to describe vanadium-uranium ore bodies in Colorado and Utah which had curved edges, and Shawe (1956) discussed the shape and genetic significance of rolls. These ore bodies differ somewhat in form and perhaps in origin from those in the Shirley Basin. The term, however, has been extended to describe the crosscutting ore bodies found in the Wyoming basins. Many of the ore bodies in the Shirley Basin are complex and consist of several rolls and lenticular bodies connected by thin bands or layers of ore. A simple roll-type ore body is shown in figure $30 B$; more complex ore bodies are illustrated in figure $30, A$ and $C$.

Although ore is found only in a zone along the altered-unaltered sandstone contact, the contact is not everywhere bordered by ore-grade material. Samples of both altered and unaltered sandstone, taken a few inches from the contact, have contained as little as $0.02-0.05$ percent uranium.

Most of the ore in the Shirley Basin is in rolltype ore bodies at or near the edges of the tongues, but some ore is in tabular, lenticular, or roll-like bodies on the top and bottom surfaces of the tongues. These bodies are generally smaller than those at the margins, but they may be of high grade. A small body of ore, about 1,200 feet east of the west edge of the upper altered-sandstone tongue, is shown in figure 31 . The ore is associated with a small irregular body of unaltered sandstone that extends upward into the lower part of the altered-sandstone tongue. The unaltered sandstone contains considerable silt, and it therefore has a low transmissivity, which accounts for its presence within the altered tongue. Continued flow of the ore-bearing solutions would have eventually altered this sandstone and destroyed the ore associated with it. Ore, associated with irregular bodies of this type and perhaps with islands of unaltered sandstone, is common near, or within several thousand feet of, the edges of the altered tongues.

Individual ore bodies in the Shirley Basin are not extensive, either in lateral dimension or in total tonnage. The largest known deposits, which extend as much as 200 feet from the edge of the alteredsandstone tongues, are as much as 30 feet thick and extend a few hundred to as much as 2,500 feet laterally along the edges of the tongues (Melin, 1964, fig. 4). Ore bodies of this size contain several hundred thousand tons of ore. The grade of mineralized sandstone ranges from a few thousandths of a percent to as high as 20 percent for small samples. 

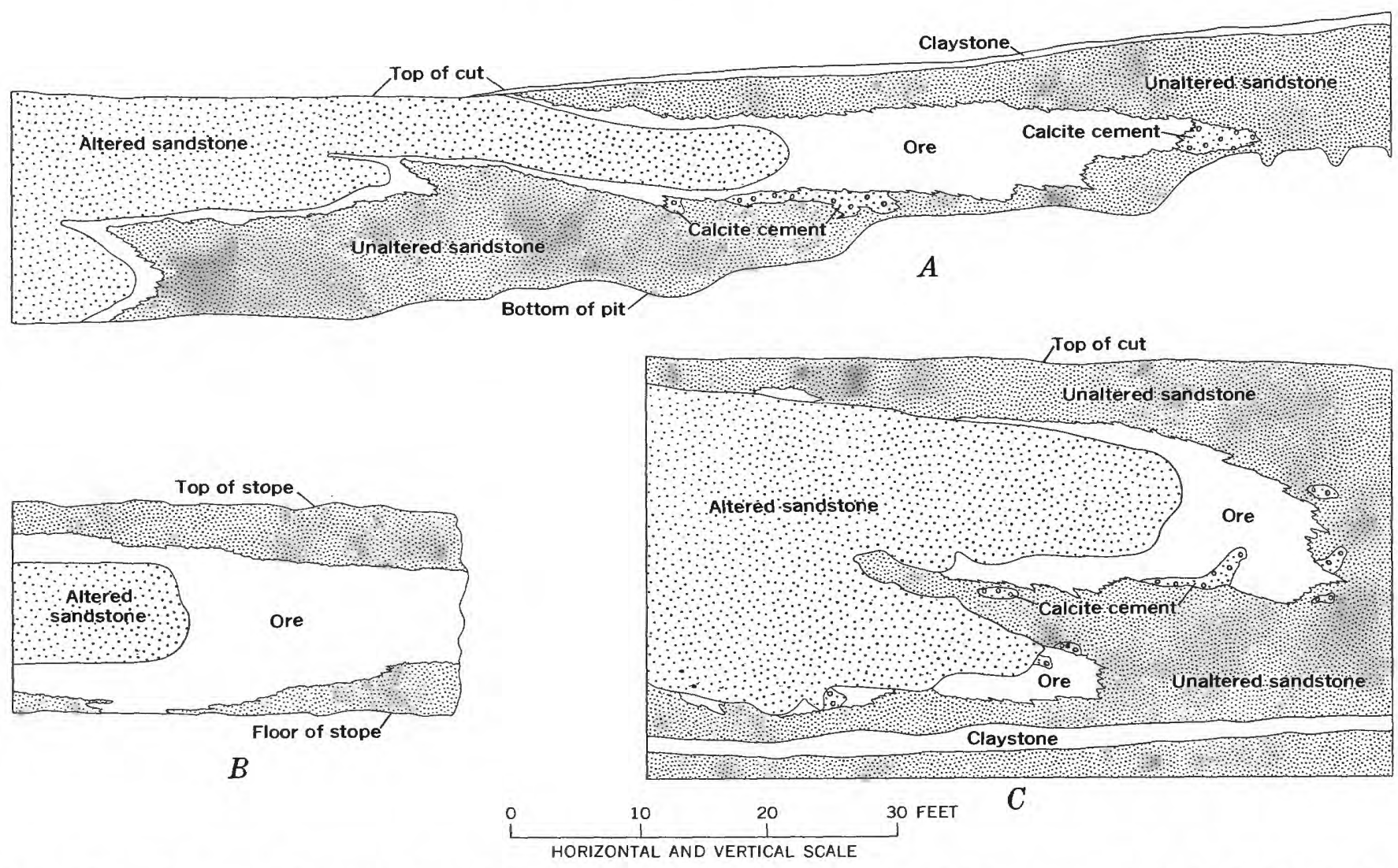

Figure 30. - Sections at the west edge of the upper altered-sandstone tongue. $A$ and $C$, two complex rolls in the Petrotomics Co. Section 9 pit; $B$, a simple "C" roll in the Utah Construction and Mining Co. mine.

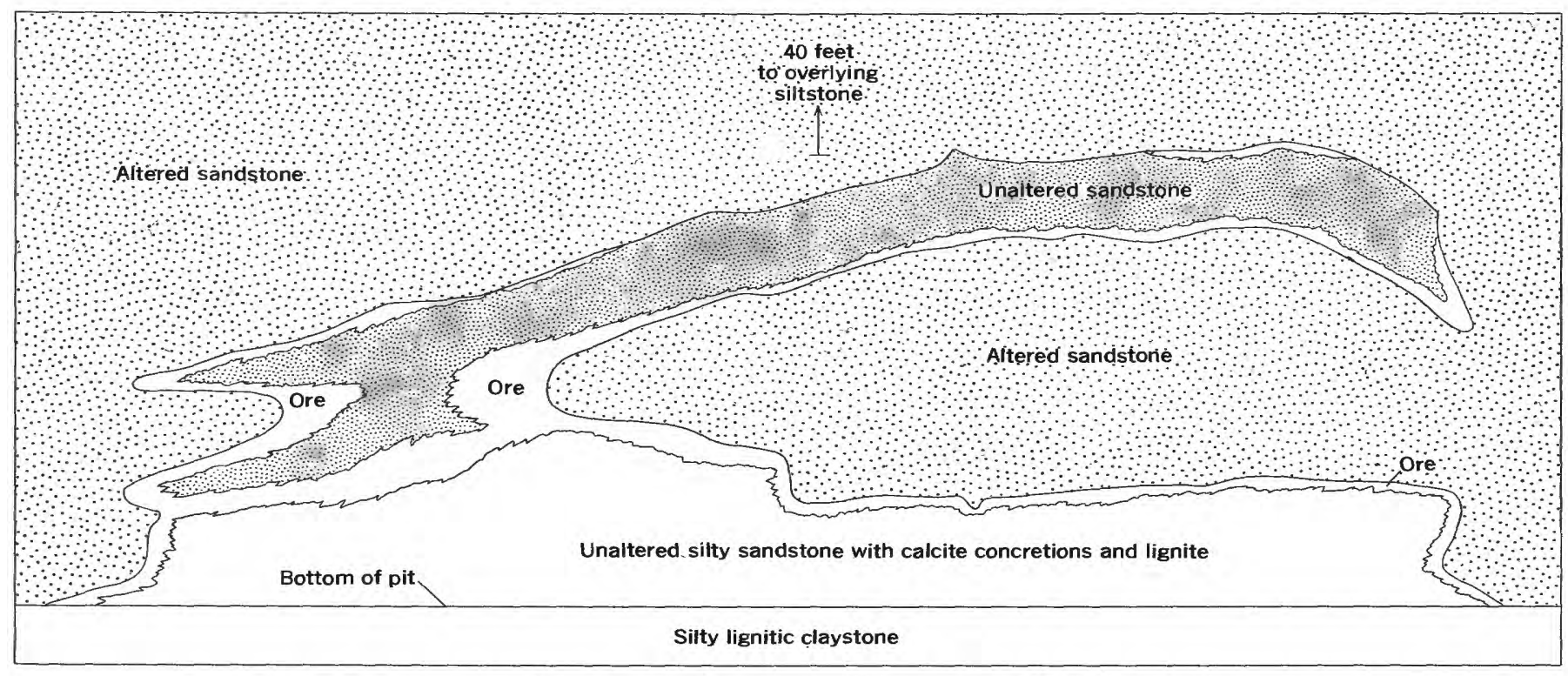

$\stackrel{10}{10} \stackrel{20}{1} \stackrel{3}{30}$ FEET

FIGURE 31. - Small ore body on bottom of altered-sandstone tongue, about 1,200 feet back from edge of tongue, Petrotomics Co. Section 9 pit. 
Average grades of material mined range from about 0.10 to 0.70 percent $\mathrm{U}_{3} \mathrm{O}_{8}$. This spread in grade of ore mined reflects economic factors relating to mining and beneficiation costs at individual properties and not to geologic factors. The highest grade ore may be adjacent to the altered-sandstone tongue, or it may be separated from the tongue by a few feet of lower grade ore. In this characteristic, the Shirley Basin deposits are similar to those described by Kashirtseva (1964) in undesignated areas in the U.S.S.R., but they are dissimilar to those described by King and Austin (1966) in the Gas Hills where they found that the peak values of uranium and many of its associated elements always occur several feet beyond the edge of the altered tongue.

The boundaries of the ore bodies, particularly the boundaries between ore and altered sandstone, are almost everywhere broad curved features that cut sedimentary structures at sharp angles. The positions and shapes of these boundaries seem to be controlled by broad geochemical processes influenced only to a very minor extent by local permeability of the host rock. Ore deposition, on the other hand, has been influenced to a considerable extent by the relative permeability of different parts of the host rock, and in many places the ore minerals accentuate permeability differences along crossbeds, bedding planes, and scours. The broad crosscutting character of the ore-altered sandstone contact is well shown in the frontispiece and in figures 32 and 33 ; the effect of permeability differences is shown on the two figures. In figure 34 is a somewhat atypical ore body that shows no broad crosscutting features but instead shows a strong control of ore deposition by crossbedding in the host rock.

Some ore bodies at the margins of the alteredsandstone tongues are asymmetric in cross section. Although exceptions are common, there appears to be some tendency for the highest grade and largest amount of ore to occur on the lower limb of an asymmetric roll. By far the largest amount and highest grade ore in the roll shown in figure 32 is in

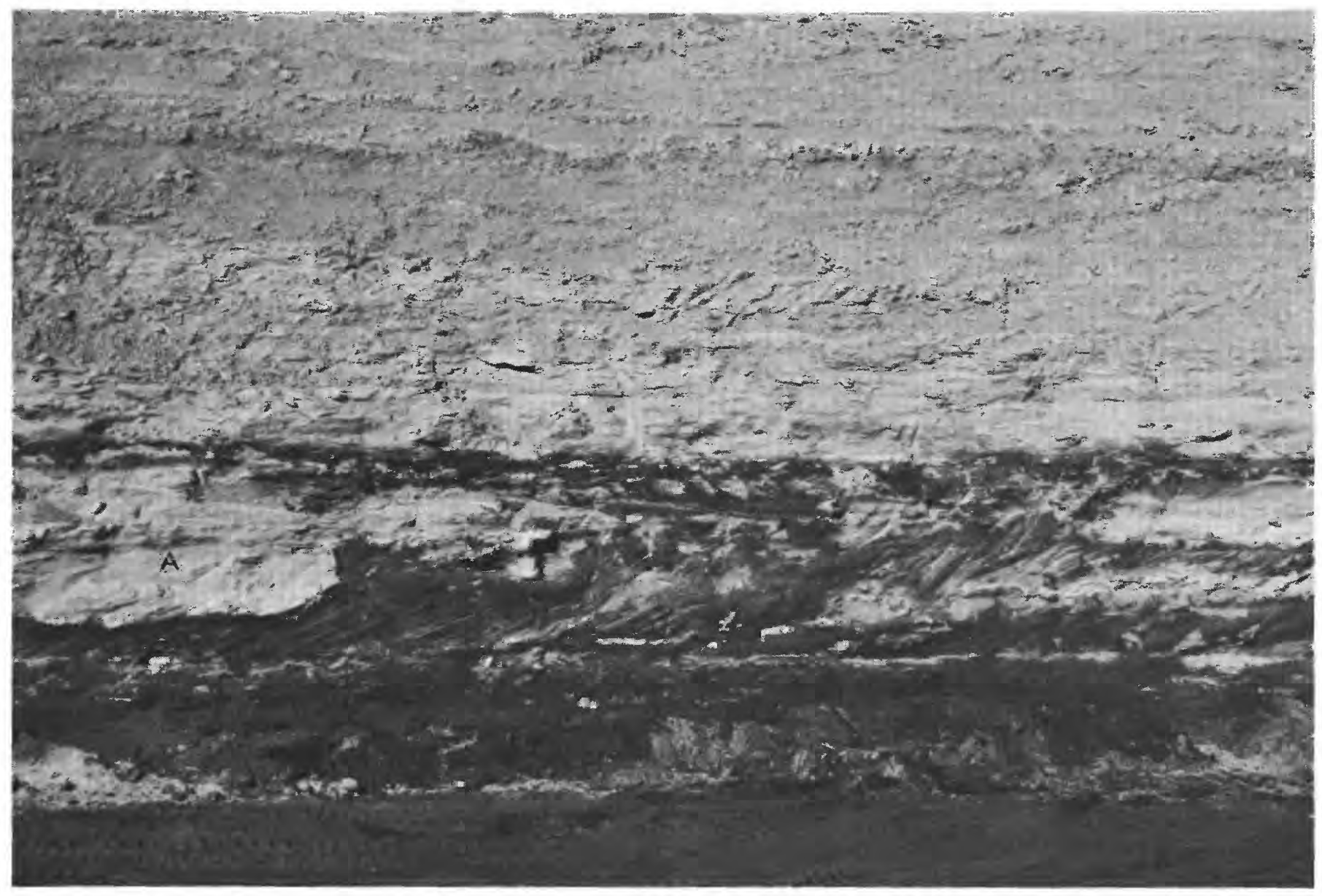

Figure 32. - Exposure on north wall, phase 1, Petrotomics Co. Section 9 pit, showing crosscutting contact between altered sandstone (A) and ore (dark gray) and accentuation of crossbedding by ore minerals. Thickness of ore zone is about 10 feet in this exposure. 
the lower limb, as is true for the rolls shown in figure 30 . Ore not at the margins of the altered tongues seems to be about equally distributed on the top and bottom surfaces of the tongues.

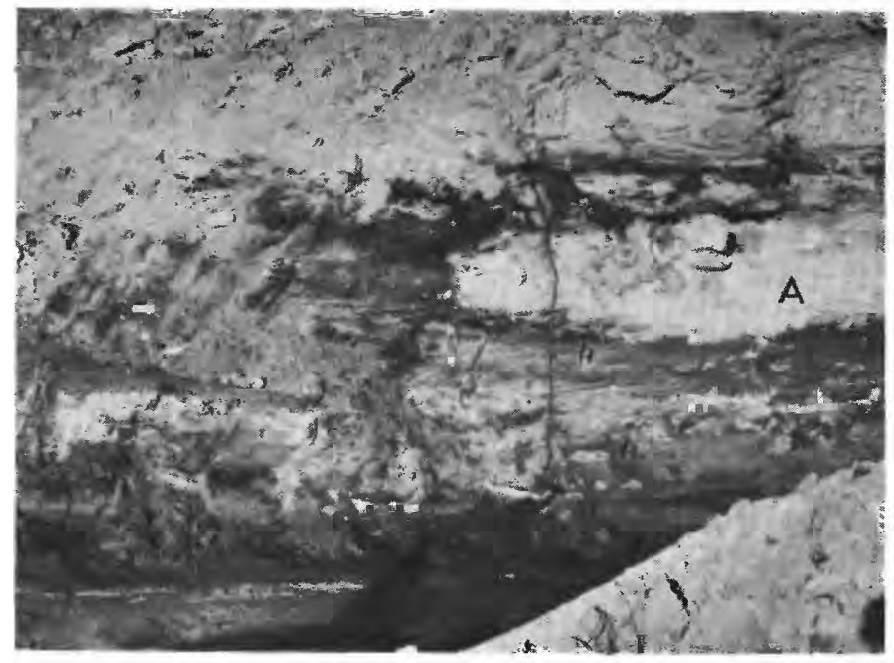

Figure 33. - Exposure on north wall, phase 1, Petrotomics Co. Section 9 pit, showing ore at edge of altered-sandstone tongue (A). Contact between altered sandstone and ore cuts crossbeds at high angles, but ore tends to be of high grade on crossbeds. Ore at this place is about 12 feet thick and contains 1-2 percent uranium.

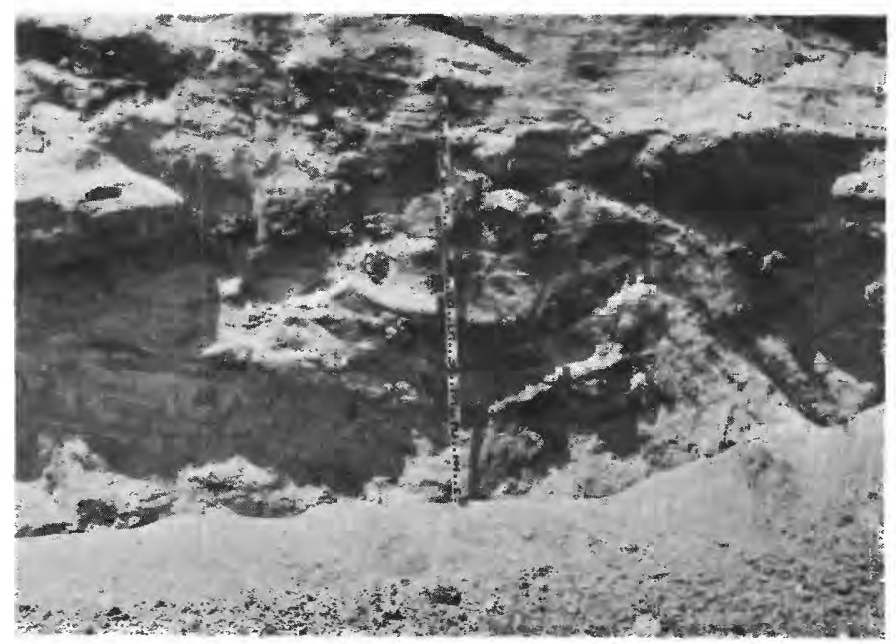

Figure 34. - Exposure in west wall, phase 1, Petrotomics Co. Section 9 pit, showing strong control of ore by permeable crossbeds in the host sandstone and no sharply defined crosscutting boundary of the ore body.

Roll-type uranium deposits have been divided into zones or sections by some authors. Kashirtseva (1964) used the terms "bypass," "black ore," and "gray ore" for subzones of ore progressively distant from the edge of an altered-sandstone tongue. King and Austin (1966) divided the mineralized rock into a "rich ore section," "intermediate section," and "protore." Some of the Shirley Basin deposits could be divided in a similar manner, but as the highest grade ore may occur in the "intermediate zone" and the "black ore" may not be the highest grade, such an unnatural division seems inadvisable here. Mineralogical and elemental zonation which has genetic significance has been recognized in the Shirley Basin deposits and is discussed later in this report.

\section{MINERALOGY AND MINERAL DISTRIBUTION}

The Shirley Basin deposits are of simple mineral composition. The principal epigenetic minerals in the ore are pyrite $\left(\mathrm{FeS}_{2}\right)$, marcasite $\left(\mathrm{FeS}_{2}\right)$, uraninite $\left(\mathrm{UO}_{2}\right)$, ferroselite $\left(\mathrm{FeSe}_{2}\right)$, native(?) selenium (Se), hematite $\left(\mathrm{Fe}_{2} \mathrm{O}_{3}\right)$, and calcite $\left(\mathrm{CaCO}_{3}\right)$. The ore is unoxidized, and it contains no secondary uranium minerals.

Pyrite is the most abundant epigenetic mineral in the sandstone host rock and has the widest distribution. It is present in unaltered sandstone far from ore, in ore, and in altered sandstone near ore. Unaltered sandstone contains about 1 percent pyrite, most of which is disseminated through the rock; some pyrite surrounds clay balls, cements gravelly crossbeds, or replaces carbonaceous material. Pyrite in unaltered sandstone is untarnished and is in euhedral or subhedral grains a few hundredths of a millimeter in diameter or in grain aggregates as much as $1 \mathrm{~mm}$ in diameter. A few pyrite grains or grain aggregates are as much as $5 \mathrm{~mm}$ in diameter. Most of the identifiable grains are either cubes, octahedrons, or cubes modified by octahedral faces; pyritohedrons have not been recognized. Much of the fine-grained pyrite is attached to the sand grains, but some of it replaces clay in the host rock. This epigenetic pyrite is unrelated to the oreforming processes, and it is considered as a "background of mineralization" on which the ore deposits were superimposed.

Pyrite is abundant in the ore and commonly is more abundant than uraninite; there is no consistent ratio, however, between uranium and sulfide-sulfur contents of ore samples (table 6).

Sandstone having the highest pyrite content is most commonly in ore adjacent to the margins of the altered-sandstone tongues, but in some places it is separated from the altered sandstone by a few feet of material with a lower pyrite content. On the outer extremity of the ore deposits, pyrite extends farther from the altered-sandstone tongues than does any other epigenetic mineral, with the possible exception of calcite. 
TABLE 6. - Uranium and pyrite contents of some Shirley Basin ores from Utah Construction and Mining Co. mine and Petrotomics Co. Section 9 pit

\begin{tabular}{|c|c|c|c|c|}
\hline \multirow[b]{2}{*}{ Sample } & \multirow{2}{*}{$\underset{\text { (percent) }}{\text { Uranium }}$} & \multicolumn{2}{|c|}{ Sulfide sulfur } & \multirow[b]{2}{*}{$\mathrm{U} / \mathrm{S}$ ratio } \\
\hline & & Percent & $\begin{array}{c}\text { Percent equivalent } \\
\text { pyrite }\end{array}$ & \\
\hline 120 & 2.34 & 1.41 & 2.64 & 1.66 \\
\hline 124 & 2.50 & & 1.84 & 2.55 \\
\hline 126 & .16 & .45 & .84 & .36 \\
\hline 127 & 1.04 & .34 & .64 & 3.06 \\
\hline 131 & 10.74 & .87 & 1.63 & 12.34 \\
\hline 187 & .22 & 1.33 & 2.49 & .17 \\
\hline 193 & .63 & .41 & .77 & 1.54 \\
\hline 196 & 19.2 & 6.93 & 12.99 & 2.77 \\
\hline 277 & 1.50 & .52 & .98 & 2.88 \\
\hline 324 & .45 & .17 & .32 & 2.65 \\
\hline $\begin{array}{l}337 \\
342\end{array}$ & $\begin{array}{l}4.62 \\
.38\end{array}$ & 6.40 & $\begin{array}{r}12.00 \\
1.29\end{array}$ & .52 \\
\hline 394 & .84 & .72 & 1.35 & 1.17 \\
\hline 403 & .51 & 1.06 & 1.99 & .48 \\
\hline
\end{tabular}

Pyrite occurs in the ore as small euhedral to subhedral crystals, as small aggregates of grains, as coatings on sand grains, and as botryoidal masses filling open spaces in the host rock. The crystal forms of the small pyrite grains and grain aggregates are difficult to determine, but cubes and cubes modified by octahedral faces appear to be most common. Most of the euhedral pyrite is untarnished or only slightly iridescent, but the pyrite coatings on

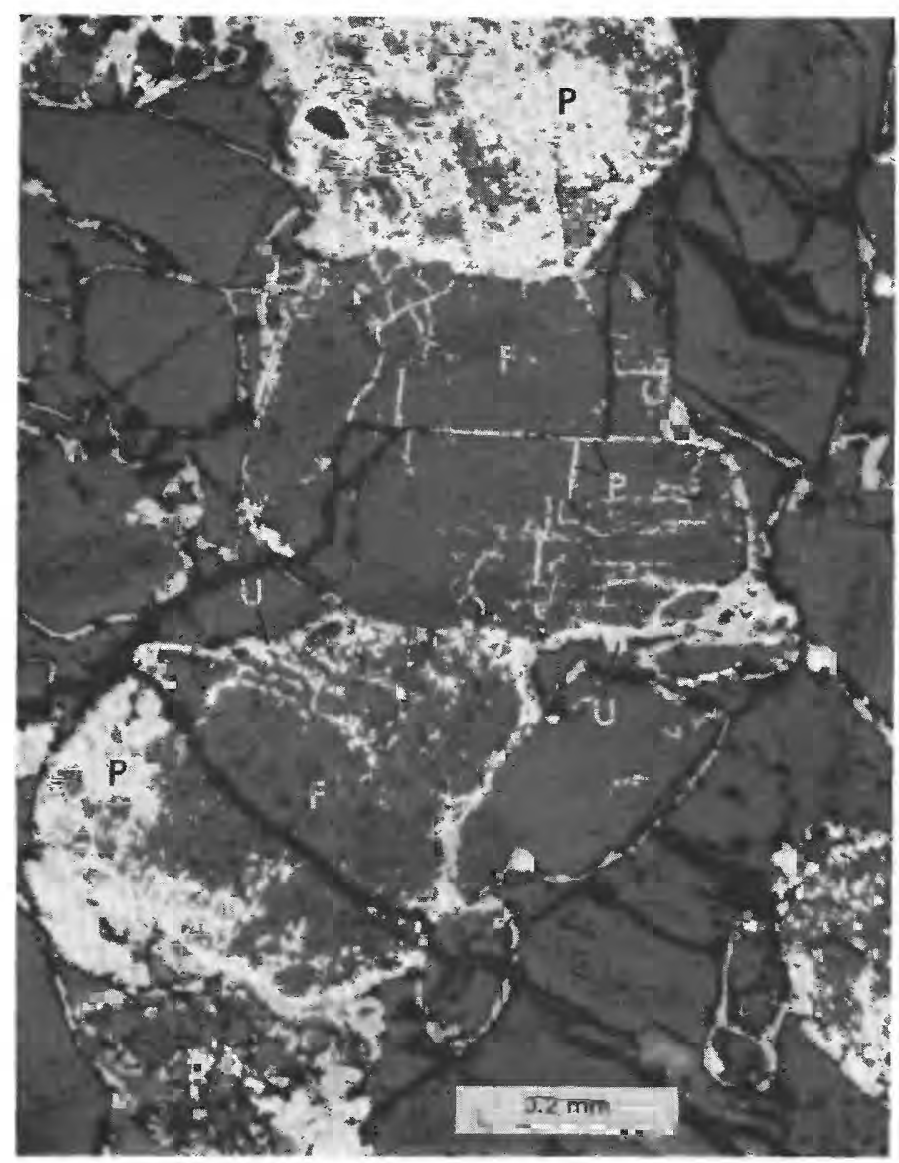

Figure 35. - Feldspar (F) replaced by pyrite (P) along cleavage and fractures. Silvery-gray mineral is uraninite $(U)$. sand grains are tarnished iridescent to bluish black. The tarnish may be due to the intimate association of pyrite and uraninite in these coatings.

Microscopic studies of polished and thin sections of ore show that single rims of mineral material on sand grains generally consist of pyrite. If multiple rims surround sand grains, the inner or inner and outer rims are pyrite, and the middle rim is uraninite. Replacement of feldspar by pyrite is common (fig. 35). Figure 36 shows pyrite in highgrade calcite-cemented ore.

In altered sandstone, pyrite is present in significant amounts only in a zone a few feet wide adjacent to ore. At other places in the altered tongues, pyrite is absent or is present only in trivial amounts (table 4). It forms small euhedral to anhedral grains or grain aggregates, similar to those in unaltered sandstone but with the important distinction that many of the grains in altered sandstone are corroded and have irregular outlines. Generally this pyrite is more tarnished than that in unaltered sandstone, although some bright untarnished grains

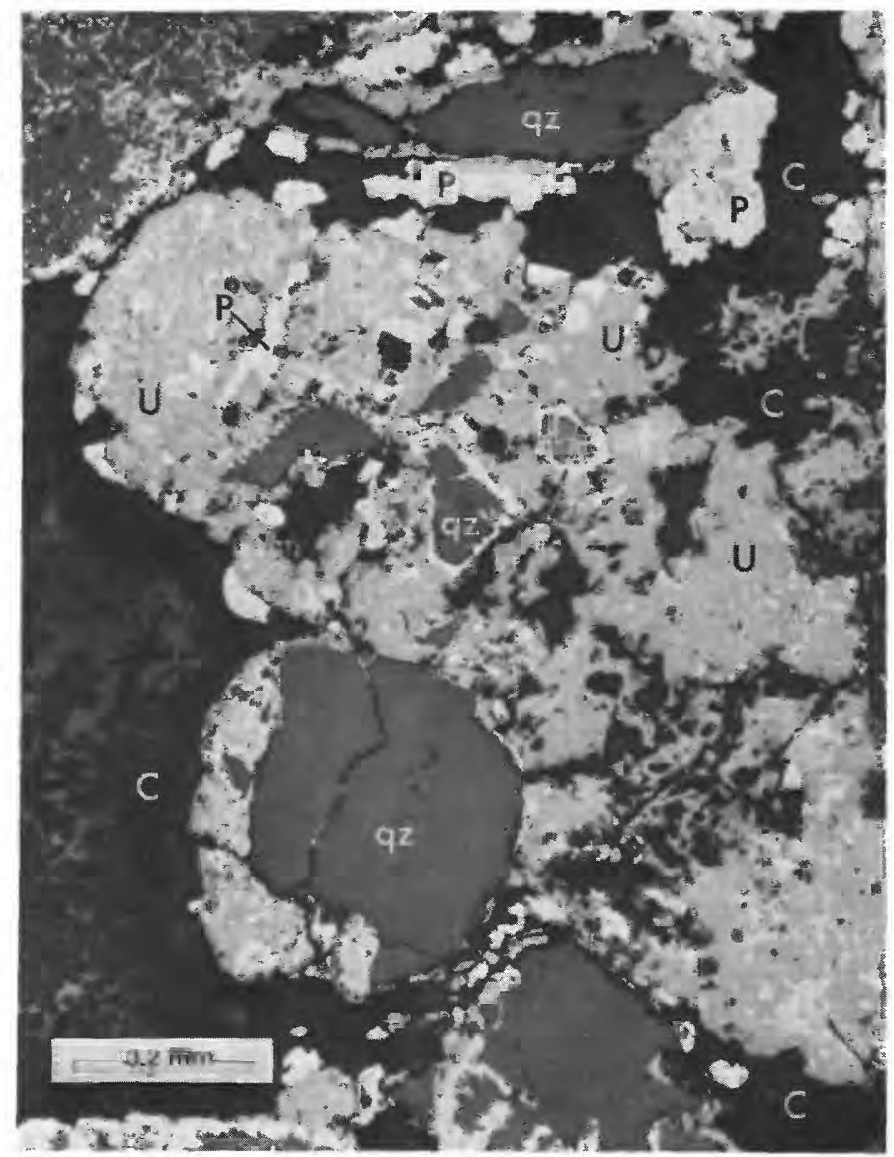

FIGURE 36. - Pyrite (P) as irregular grains in uraninite (U) and in rims surrounding quartz grains ( $q z$ ). Pyrite and uraninite fill open spaces in high-grade calcite-cemented ore (C) from Petrotomics Co. Section 9 pit. 
are mixed with the tarnished ones. The very small pyrite grains that are attached to the sand grains of unaltered sandstone are not present in altered sandstone.

King and Austin (1966) described morphologic differences in pyrite from altered, unaltered, and ore-bearing sandstones in the Gas Hills area of Wyoming. These differences are not characteristic of similar rock units in the Shirley Basin, although selected samples may show some of the differences they described.

Marcasite is a very minor constituent in ore and seems to be most abundant in ore near the contact with altered sandstone. It can be visually identified only in polished and thin sections of ore, where it is in the form of small irregular or lathlike grains intergrown with pyrite or isolated grains dispersed through calcite. In polished sections it contrasts with pyrite by having a less brassy color, a less pitted surface, and strong anisotropism. Its presence in ore has been confirmed by X-ray diffraction techniques. The distribution of marcasite is similar to that of pyrite.

Uraninite is the only uranium-bearing mineral that has been identified in the Shirley Basin ore, but coffinite may be present and unidentified. Some uranium may be present as an organic-uranium compound or chelate, but because of the very complex nature of this geochemical field, investigations to determine the presence or absence of such compounds were not attempted. X-ray diffraction studies indicate that the uraninite contains considerable $\mathrm{UO}_{3}$, probably formed by auto-oxidation of $\mathrm{UO}_{2}$. Uraninite coats grains of the host sandstone, fills interstices between grains, and in some places fills fractures in grains or replaces grains-particularly feldspar. It was deposited through a zone much wider than the selenium zone but narrower than the zone in which pyrite and marcasite were deposited.

Uraninite forms the inner rim on sand grains in a few samples of ore, but in most samples it forms an outer rim on pyrite-marcasite or, if three rims are present, the middle rim between two pyritemarcasite rims. In a few polished sections of ore, minute veinlets of pyrite-marcasite cut through uraninite. They are so small that it is impossible to establish continuity with either the inner or the outer pyrite-marcasite rim, but they probably represent late (outer rim) pyrite-marcasite that fills shrinkage cracks in uraninite. Other interpretations are possible. Figure 37 shows the relations just described.

Selenium is abundant in a very narrow zone astride the contact between altered sandstone and ore. The zone is sharply defined, and in some places the selenium content drops from 0.10 percent to a few parts per million in a distance of about 1 foot. The selenium-bearing mineral in ore probably is native selenium. One sample 6 inches from the altered-sandstone tongue contained a number of small reddish-gray radiating acicular crystals associated with pyrite; these crystals probably were native selenium, but they were too small and too few to be positively identified. Native selenium has been described from similar deposits in Russia (Kashirtseva, 1964) and at Ambrosia Lake, N. Mex. (Granger, 1963).

Ferroselite has been identified in altered sandstone near the contact with ore. It occurs in twinned clusters attached to sand grains or to clay. The clusters range from a few hundredths to as much as $0.2 \mathrm{~mm}$ in diameter. Similar ferroselite clusters have been described in the Powder River Basin uranium deposits (Granger, 1966). The quantities of ferroselite in altered sandstone and of native(?) selenium in ore-bearing sandstone do not appear to

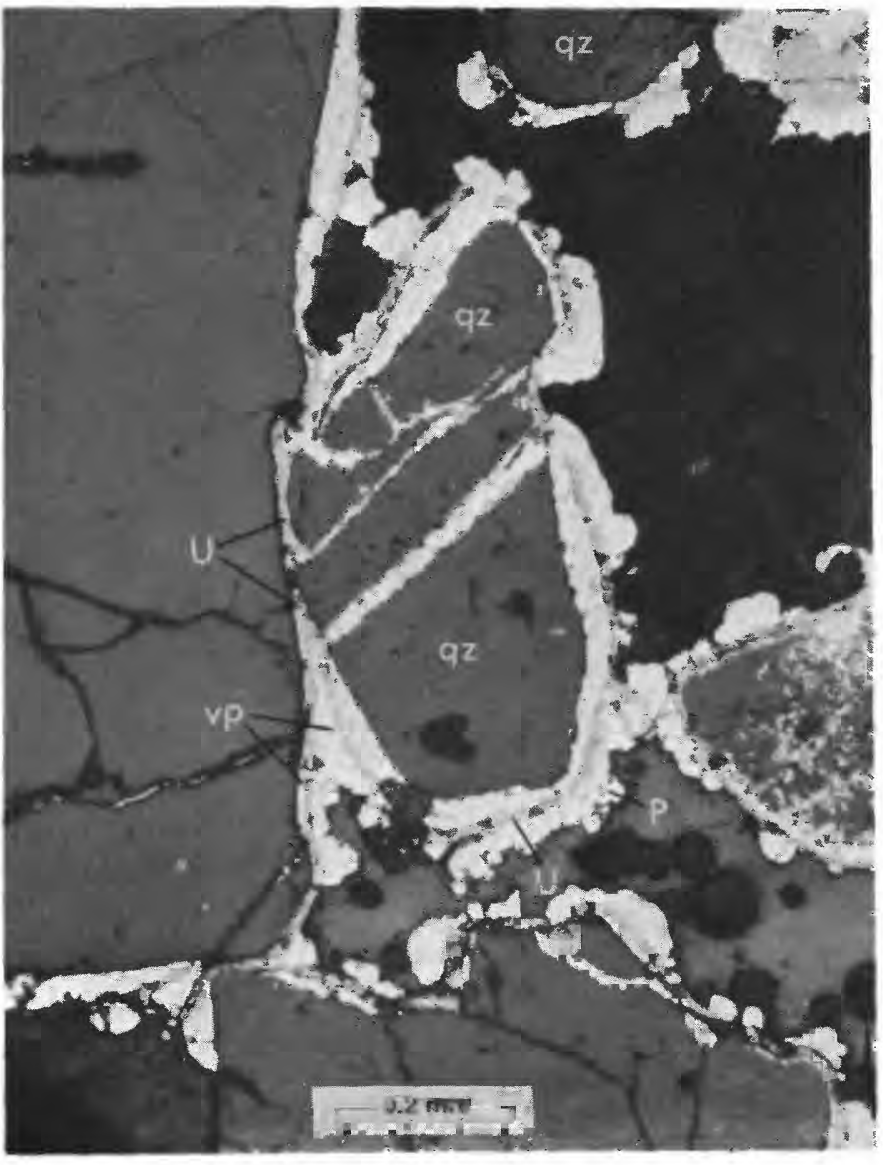

Figure 37. - Polished section of ore from Petrotomics Co. Section 9 pit, showing pyrite-marcasite $(P)$ and uraninite (U) rims on quartz sand grains (qz); small veiniets of pyrite-marcasite (vp) cut some of the uraninite rims. 
be sufficient to account for the selenium content of these rocks. Perhaps the fragile ferroselite crystal aggregates were broken in preparation and separation of the samples, and thus became unidentifiable, or perhaps some of the selenium is contained in the pyrite. Typical twinned ferroselite crystals are shown in figure 38 .

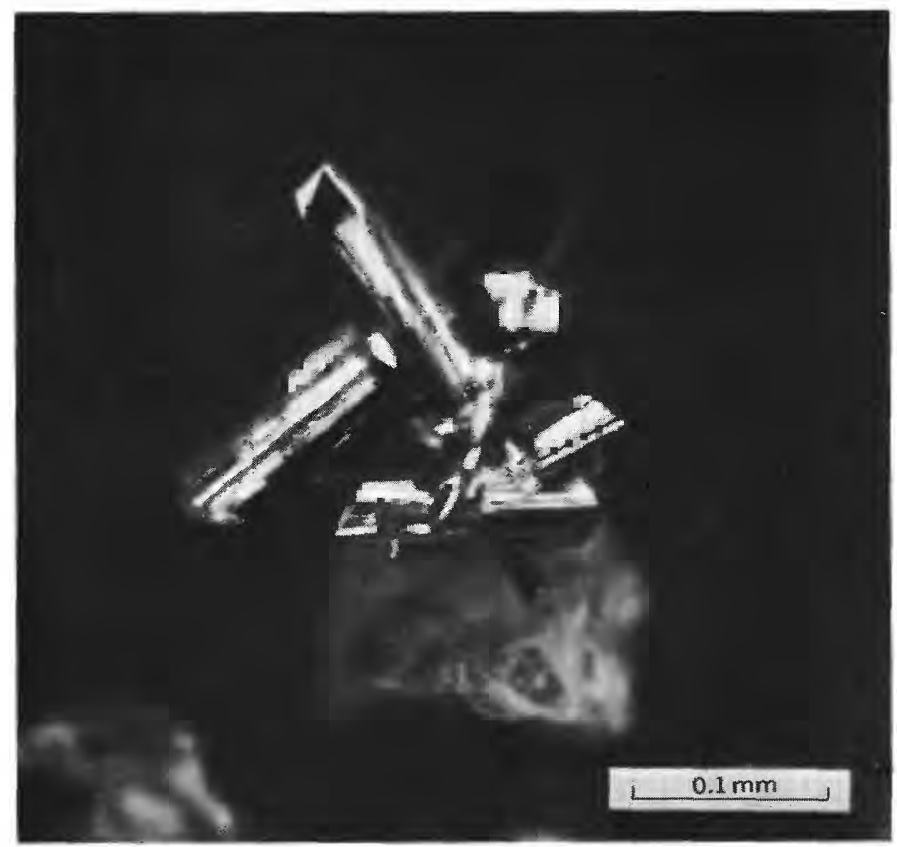

FIGURE 38. - Twinned ferroselite crystals in heavy mineral separate from altered sandstone in Petrotomics Co. Section 9 pit.

Calcite occurs as a cementing material in ore and in a zone or halo in unaltered sandstone surrounding ore. It is less uniformly distributed through the host sandstone than are the other epigenetic minerals, and in most places it occurs in concretionary masses ranging from a few inches to 15 feet in maximum dimension. The calcite cement in most places is localized around large accumulations of carbonized plant debris; one such concretionary mass is shown in figure 39. These concretions are generally streaked with hematite, and they may contain uranium. Those that do not contain uranium may have a rind of high-grade friable uranium ore. In some places, small calcitecemented masses of sandstone, which appear to be corroded remnants of larger concretions, are in zones a few feet to as much as $\mathbf{1 0}$ feet wide that border, and extend slightly into, altered-sandstone tongues.

Studies of thin and polished sections of ore show that calcite may be younger or older than uraninite.
In samples of high-grade ore, taken from the Petrotomics Co. Section 9 pit about half way between the inner and outer edges of the ore body, calcite replaced feldspar rimmed by uraninite or pyrite or both. Replacement ranged from incipient to complete, and the calcite within the rim is optically continuous with that outside the rim. The younger age of the calcite with respect to the uraninite and pyrite is unquestionable. The observed relations are shown in figure 40.

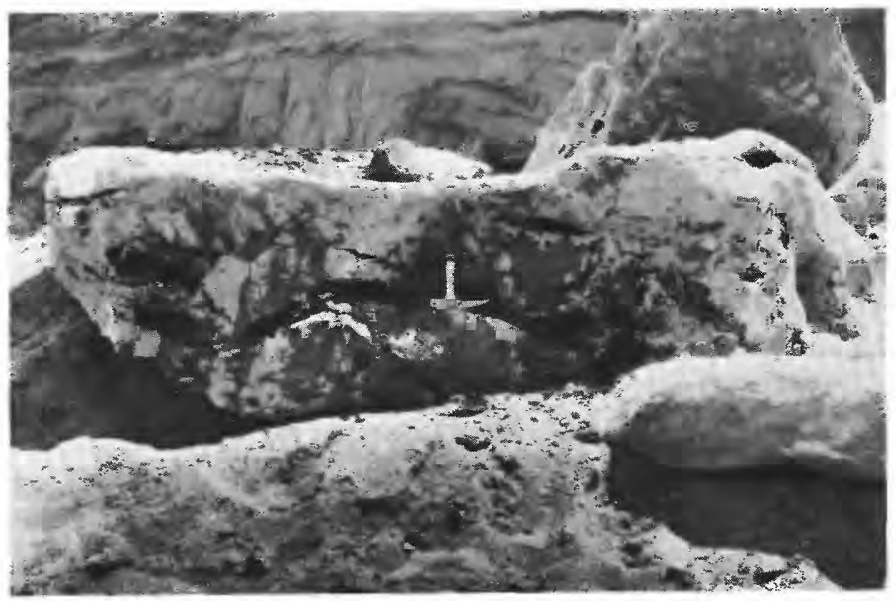

FIGURE 39. - Calcite-cemented slab of ore-bearing sandstone in waste dump from the Petrotomics Co. Section 9 pit, showing large percentage of carbonaceous material in slab. Concretionary masses of this type generally are in a halo around ore.

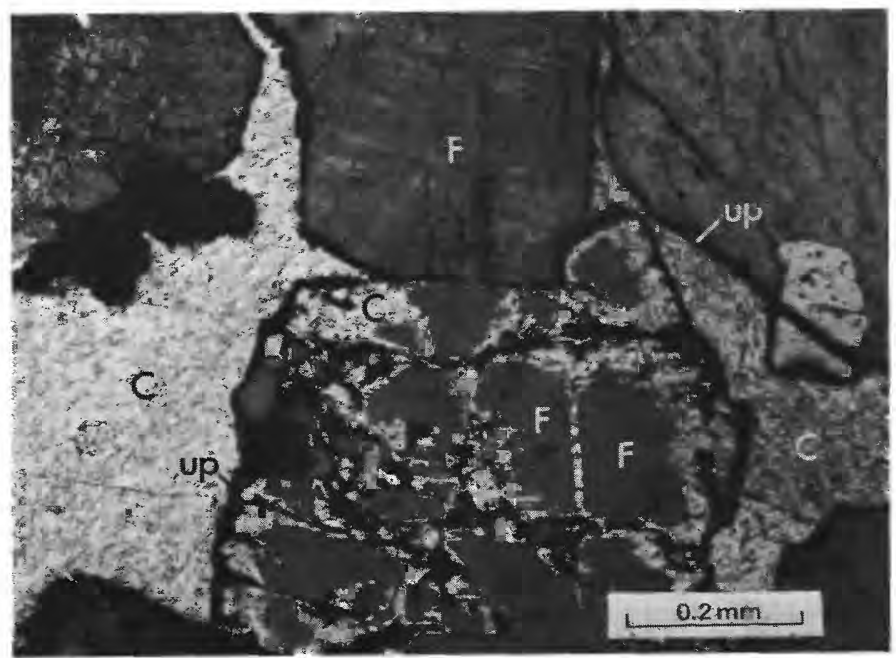

$A$

FIGURE 40. - Thin sections of high-grade calcite-cemented ore from Petrotomics Co. Section 9 pit, showing degrees of replacement of feldspar by calcite. $A$, Feldspar (F) rimmed by uraninite-pyrite (up) and incipient replacement of feldspar by calcite (c). $B$, As in $A$, but considerable replacement of feldspar by calcite. $C, \mathrm{As}$ in $A$, but complete replacement of feldspar by calcite, leaving only uraninitepyrite rim "floating" in calcite. Quartz $(Q)$ is rimmed by uraninite but is not replaced by calcite. 


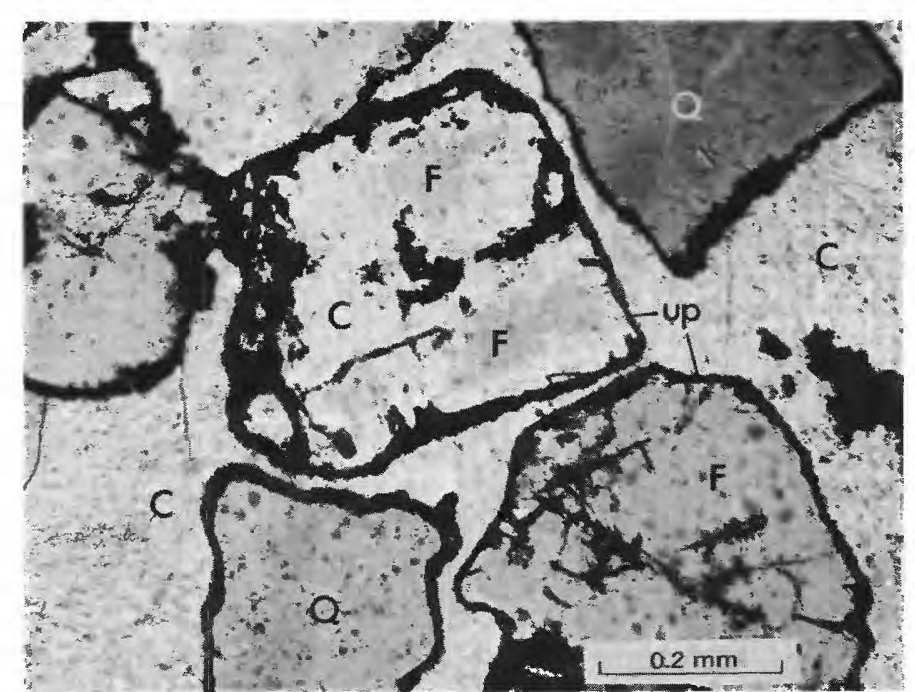

$B$

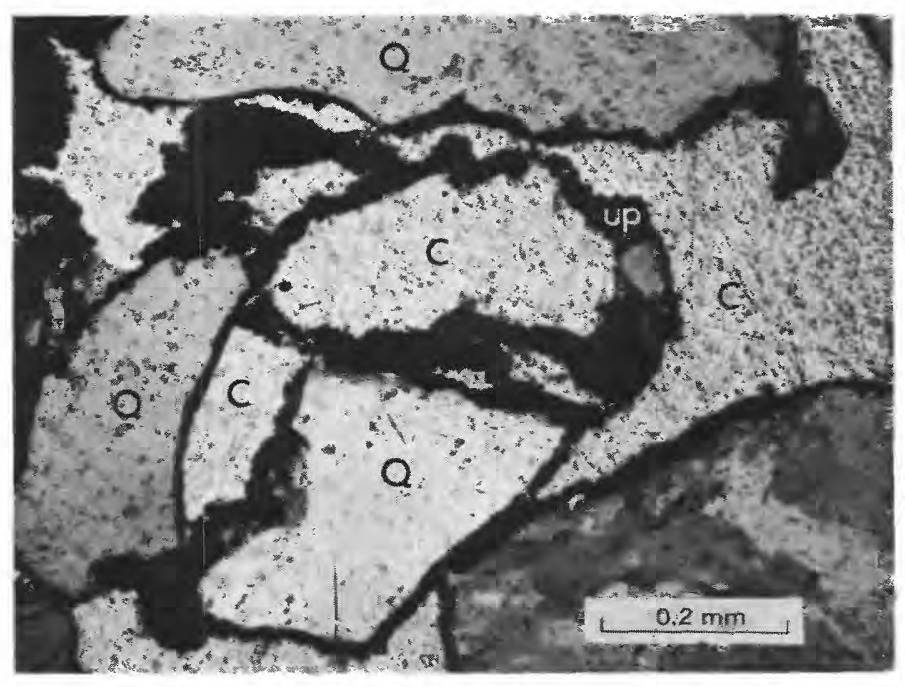

C

Calcite, definitely older than uraninite, was described by Melin (1964) in the ore bodies at the Utah Construction and Mining Co. mine, and small calcite concretions, barren in their interior but enclosed in an altered rim by a skin of high-grade ore, have been noted near the outer edge of ore bodies in the Petrotomics Co. Section 9 pit. Calcite in these samples is older than uraninite. Part of a small concretion enclosed in ore is shown in figure 41 .

Hematite is almost everywhere associated with calcite, and it is restricted to the outer parts of the ore bodies or to a zone not more than 10-20 feet from ore on the unaltered side. It occurs in streaks, bands, and irregular masses, and it ranges in color from brick red to purplish red and in length from a few inches to several feet. About half of the hematite coats grain surfaces; the remainder occurs as grains and irregular masses along cleavage planes of feldspar, biotite, hornblende, and other ferruginous minerals and rarely as isolated grains in calcite. Many of the hematite grains have dark metallic centers, others have rectangular outlines; these facts suggest that this hematite resulted from alteration of pyrite, marcasite, or perhaps magnetite. Some fresh pyrite is associated with hematite-bearing calcite.

In addition to the minerals just described, several elements show a systematic distribution in and near the ore deposits. Their mineralogy is not known, and they are discussed under "Distribution of Elements."

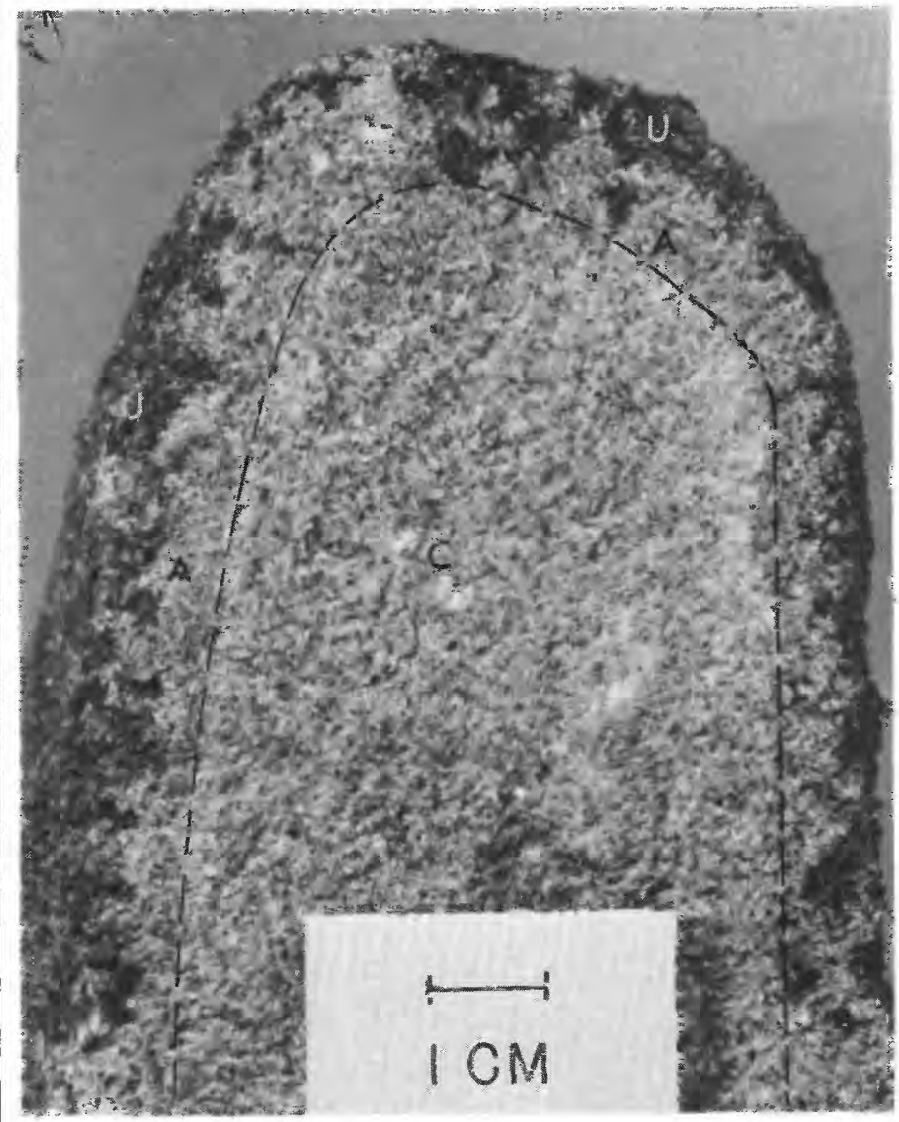

Figure 41. - Calcite-cemented concretion showing unaltered barren medium-gray core (C), slightly darker gray altered $\operatorname{rim}(\mathrm{A})$, and outer skin of uraninite (U).

PARAGENESIS OF THE ORE AND ASSOCIATED MINERALS

Only the paragenetic relations of the minerals deposited by the ore-bearing solutions are discussed in this section of the report; sedimentary and diagenetic minerals, including diagenetic pyrite in unaltered sandstone (see p. 53), are not considered. 
Pertinent to this discussion is the concept, to be developed later in the report, that the zone of ore deposition was dynamic and moved slowly downdip, in the direction of flow of the ore-bearing groundwater, by oxidation and solution on the upstream side of the zone and by reduction and deposition on the downstream side.

Figure 42 is a graphic summary of the data on mineralogy and mineral distribution. It is an approximation in which the ends of the arrows on the left side of the figure show the points at which the ore-bearing solution, as it moved away from the altered-sandstone tongue, started to deposit each element or compound. The arrow lengths show the relative widths of the intervals through which deposition occurred, and the arrowheads show the points at which deposition stopped.

Because the zone of deposition was dynamic, the sequence of mineral deposition from a unit of solution moving through the zone differs from that at a given point in the zone.

Native selenium was the first mineral deposited from a unit of solution flowing from the altered sandstone through the zone of deposition (from left to right, fig. 42). Pyrite and marcasite, uraninite, and calcite, in that order, were the next minerals to form, and they mostly overlapped one another. Hematite was probably the last mineral to form, although the point at which deposition started, or the point at which other iron-bearing minerals started to alter to hematite, is not known with accuracy.

The sequence of mineral deposition at a given point in the host rock is almost the reverse of that from a unit of solution. Iron sulfide is deposited first at a given point, followed by hematite, calcite, and uraninite as the zone of deposition moves forward. Native selenium, the first mineral to form from the unit of solution, is the last to be deposited at a given point.

\section{DISTRIBUTION OF ELEMENTS AND COMPOUNDS}

Analyses of many samples of roll-type ore bodies, and the altered and unaltered sandstones associated with them, show that several elements and compounds are systematically distributed in and near the ore and that some elements and compounds show consistent correlations with each other. An understanding of these distribution patterns is prerequisite to an understanding of the processes of ore emplacement, and, therefore, data on the distribution of several elements and compounds are discussed in detail.

For the convenience of the reader, minute amounts of most ore constituents will be expressed in parts per million, and larger amounts will be expressed in percentages; $1 \mathrm{ppm}$ is equal to 0.0001 percent.

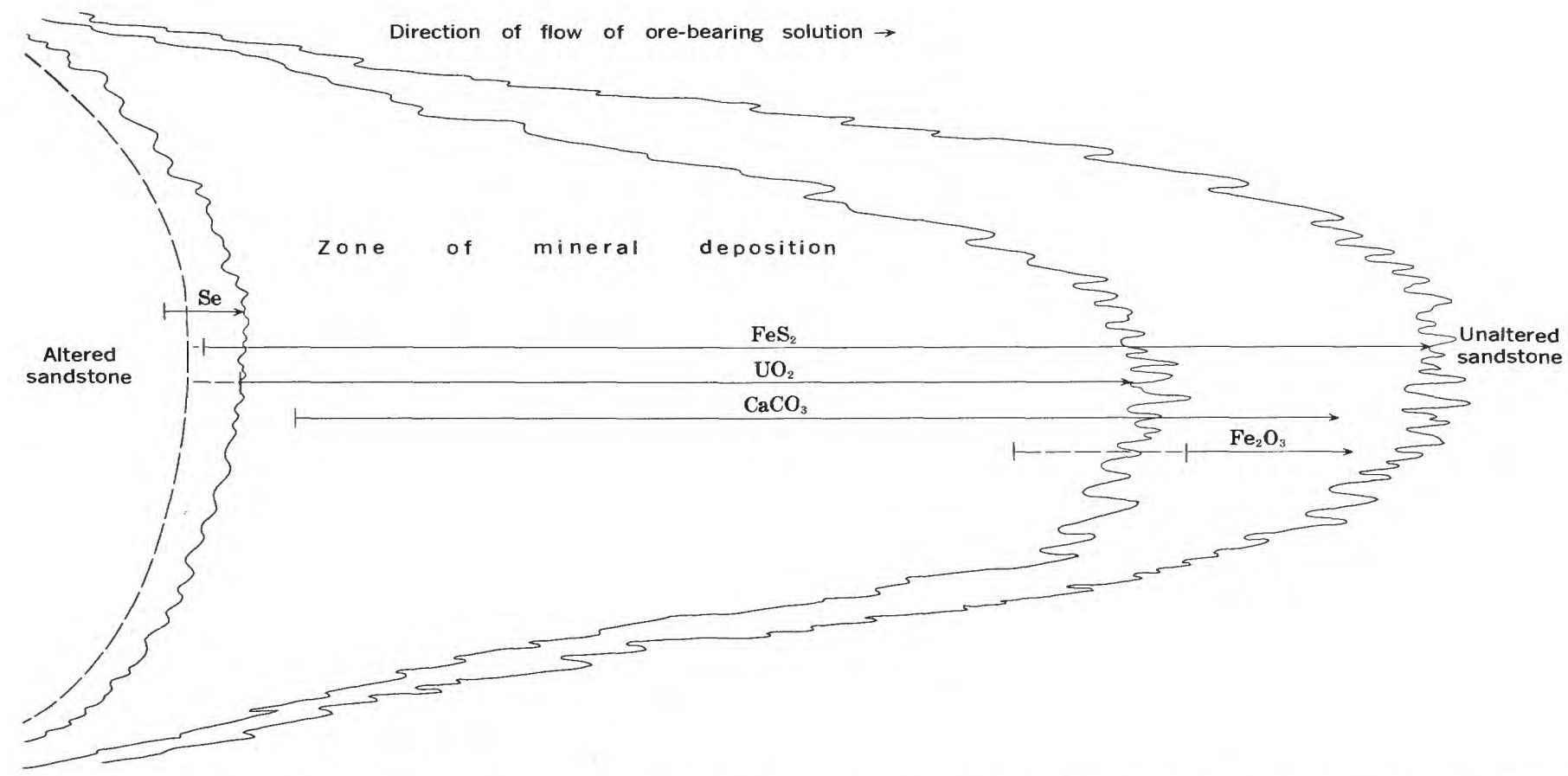

FIGURE 42. - Summary of mineral deposition in the Shirley Basin. Arrow lengths show relative positions and widths of zones in which various minerals were deposited; dashed lines are possible deviations from normal conditions. No scale. 
The reference point for the discussion will be the terminal edge of the altered-sandstone tongue, variously called: (1) A solution interface or front by King and Austin (1966), (2) a redox interface by Adler (1964), and (3) an altered-unaltered sandstone interface or contact by Bailey (1965), Melin (1964), and Harshman $(1962,1966)$. The edge of the altered-sandstone tongue in the Shirley Basin is not now, and probably never was, a boundary between two solutions of different character, nor was it a redox interface for all of the elements in the deposits. For these reasons the physically descriptive term "edge of altered-sandstone tongue" will be used in this report to describe the reference point. The distribution of elements was determined from samples taken in suites across the terminal edges of altered-sandstone tongues in the Utah Construction and Mining Co. mine and the Petrotomics Co. Section 9 pit. Sampling intervals were as short as 2 inches and as long as 10 feet. All samples were analyzed spectrographically for 51 elements and chemically for total iron, ferrous iron (corrected for iron in $\mathrm{FeS}_{2}$ ), ferric iron (by difference), mineral carbon, organic carbon, selenium, sulfide sulfur, sulfate sulfur, and total sulfur, as well as for uranium and equivalent uranium. Analyses for phosphate, arsenic, magnesium, and mercury were made on selected samples or sample suites.

Uranium and Equivalent UraniUm

Figure 43 illustrates the distribution of uranium and its daughter products in four typical Shirley Basin ore bodies. Uranium is distributed unevenly in each of the four rolls, being most abundant at the margins of the altered-sandstone tongues and gradually decreasing in amount away from the tongues. This contrasts with the ore rolls in the Gas Hills district of Wyoming where King and Austin (1966) reported that the peak values of uranium and many of its associated elements do not occur at the front, but several feet beyond it, within the mineralized zone.

The uranium content of unmineralized sandstone ranges from about 4-8 ppm $(0.0004-0.0008$ percent), a value based on analyses of samples of unweathered sandstone that is exposed above the ore-bearing interval in the walls of the Petrotomics Co. Section 9 pit and of samples of sandstone from the ore-bearing interval that are considered to be unaltered.

Altered sandstone generally contains only slightly more uranium than does unaltered sandstone, but in a few places the outer few inches, or in rare in- stances the outer few feet, of the altered tongue contains ore-grade material. Where the edges of the tongues are of ore grade, the uranium content of altered sandstone decreases rapidly away from the edge and drops to a normal content of 6-15 ppm ( 0.0006 to 0.0015 percent) uranium in samples 10 feet or more from the edge.

Uranium is not in equilibrium with its daughter products in most of the Shirley Basin deposits. Values from radiometric analyses (beta-gamma, expressed as percentages of equivalent uranium) exceed those from chemical analyses (fluorimetric, expressed as percentages of uranium) on samples of poorly mineralized sandstone, both altered and unaltered, and values from chemical analyses exceed those from radiometric analyses on samples of ore and of ore-grade altered sandstone $(0.1$ percent or more uranium). The character of the disequilibrium thus seems to depend on the uranium content of a sample rather than on the type of material sampled. In general, in sandstone with less than about 0.07 percent uranium, the $\mathrm{U} / \mathrm{eU}$ ratio will be less than 1 , and in sandstone with more than 0.1 percent uranium, the same ratio will be more than 1 . There are exceptions to this generalization. The equivalent-uranium and uranium contents of 175 samples of altered and unaltered sandstone and of ore are plotted in figure 44. A plot of the equivalent-uranium and uranium contents of 290 samples from the Ambrosia Lake area of New Mexico shows similar $\mathrm{U} / \mathrm{eU}$ ratios (Granger and others, 1961).

If roll-type deposits originate from a continuing process of oxidation, transportation, and reduction of uranium in flowing ground water, then a residuum of daughter products in the altered-sandstone tongue could result if uranium were more readily leached from the sandstone than its daughter products. It appears that in the Shirley Basin such differential leaching may have taken place; taking into account the normal imbalance that is characteristic of all low-grade mineralized samples, there is still some factor which causes the imbalance of equivalent uranium and uranium to be much greater in the altered-sandstone samples than it is in the unaltered samples. This is well shown in figure 44, where almost all the analyses of altered sandstone lie at a greater distance from the line representing equilibrium conditions than do the corresponding analyses of unaltered sandstones which have similar uranium contents. The degree of imbalance of uranium and equivalent uranium in samples of poorly mineralized sandstone should be useful in determining the presence of alteration in drill cuttings and drill cores. 

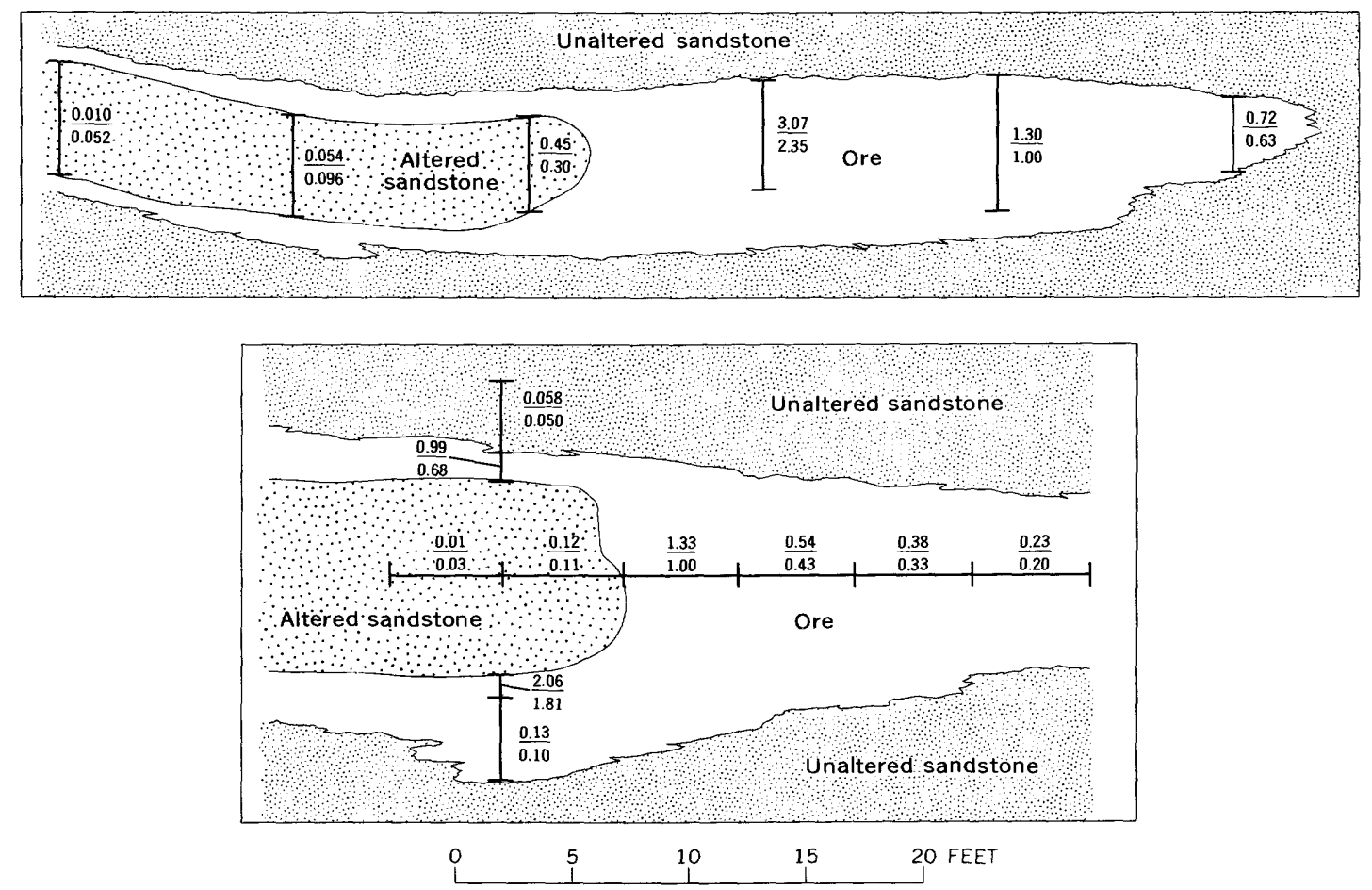

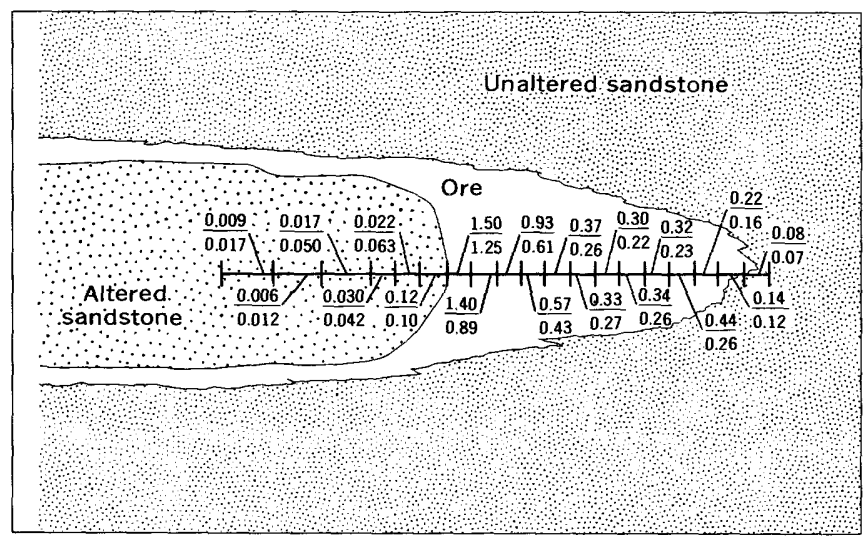

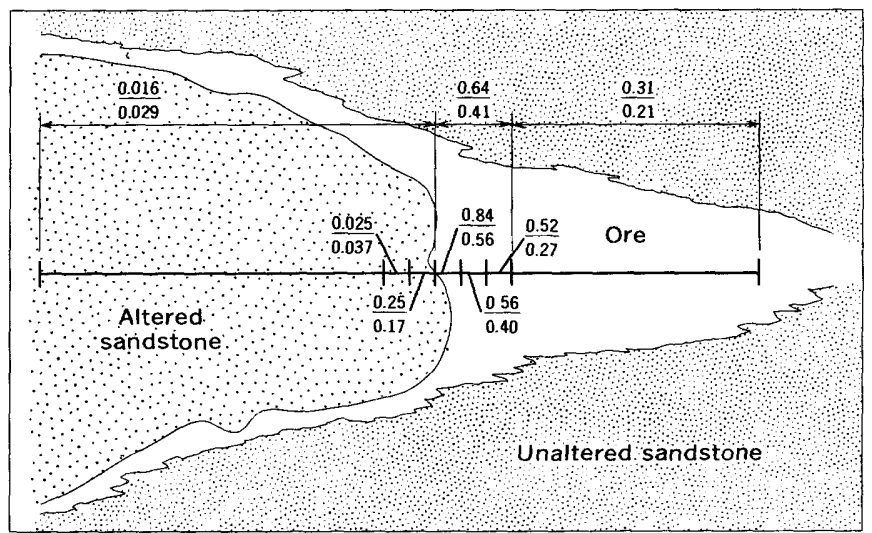

10 FEET

Figure 43. - Cross sections at the edges of altered-sandstone tongues, showing positions and contents of samples. Percentages of uranium (numerator) and equivalent uranium (denominator) expressed as the fraction $\mathrm{U} / \mathrm{eU}$.

IRON

Iron is the most abundant epigenetic element in the ore deposits. It combines with sulfur to form pyrite and marcasite in the ore and unaltered sandstone and with silica and alumina to form highiron montmorillonite in the altered sandstone. Iron combined with oxygen forms the hematite associated with calcite concretions in ore and unaltered sandstone and the goethite and limonite in the altered-sandstone tongues.

The distribution of uranium, of ferrous, ferric, and total iron, and of ferrous iron in sulfide and nonsulfide minerals in a typical roll is shown in figure 45. Unaltered sandstone contains about 0.8 percent total iron, about two-thirds of which is in the ferrous state. Ferrous iron is about equally divided between sulfide and other iron-bearing minerals. The high total iron and high ferrous iron in sample 308 are due to a concentration of pyrite around carbonaceous material in the sandstone.

The ore is enriched in iron, most of which is in the ferrous state and is present as the minerals pyrite and marcasite. Sample 319 has considerable ferrous iron in minerals other than pyrite, and, since this sample is also high in $\mathrm{SO}_{4}$, the iron may be present in a ferrous sulfate mineral as yet unidentified in the Shirley Basin deposits. Ferric iron is 


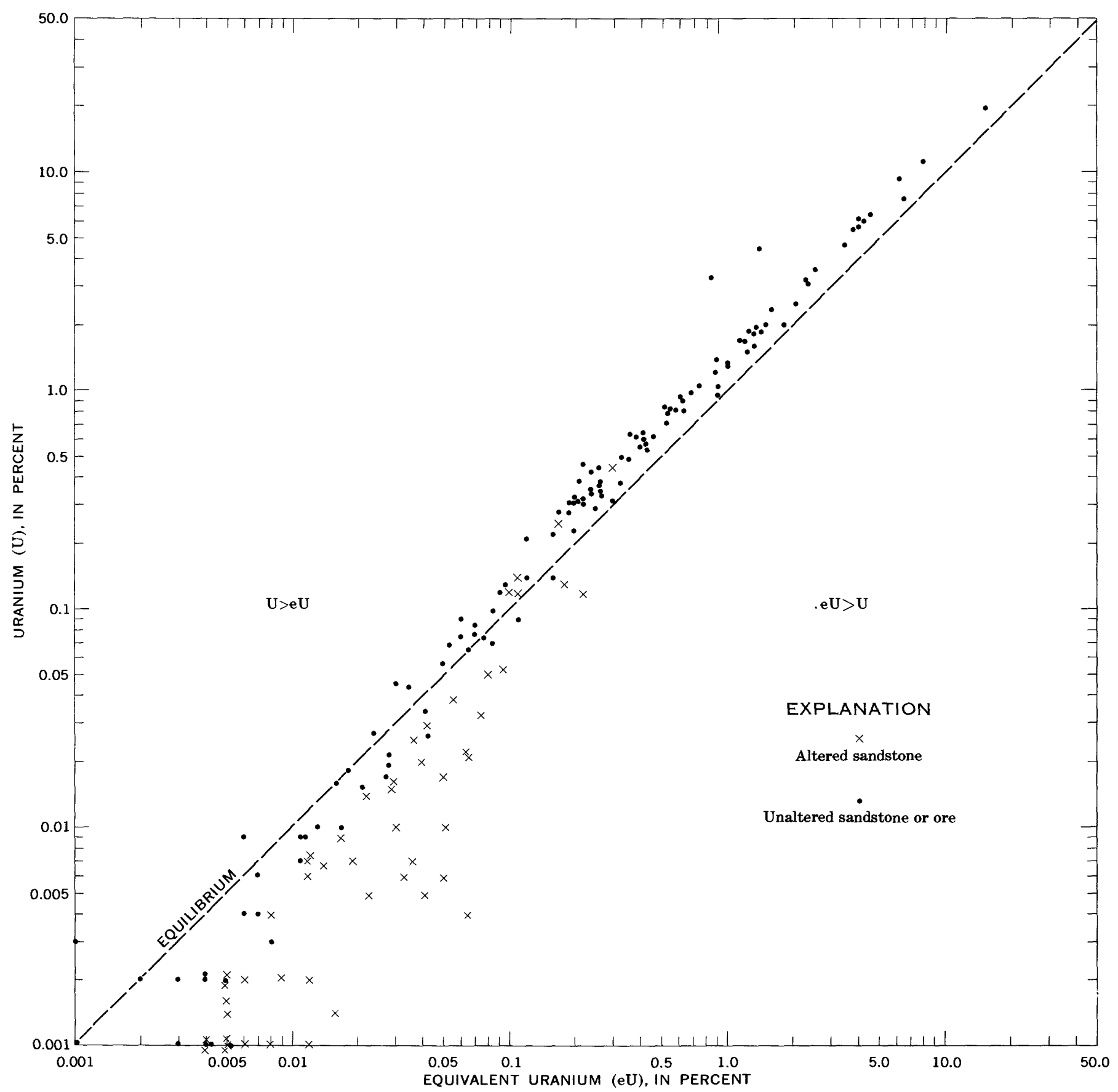

FIGURE 44. - Equilibrium relations of 175 samples of mineralized sandstone from Shirley Basin.

virtually absent in high-grade ore near the margins of the altered-sandstone tongues; it is present in minor amounts near the outer edges of ore bodies.

Altered sandstone generally contains $0.8-0.9$ percent total iron, about the same as does unaltered sandstone. At the edge of the altered tongue, total iron decreases somewhat in amount; most of it is in the ferrous state, some in pyrite and some in other iron-bearing minerals. A few tens of feet from the edge of the tongue the amounts of ferrous and ferric iron are about equal, and the amount of ferrous iron in pyrite becomes almost nil. Pertinent to the problem of origin of uranium deposits are (1) the high $\mathrm{Fe}^{+2} / \mathrm{Fe}^{+3}$ ratio in unaltered sandstone compared with the same ratio in altered sandstone, (2) the low-ferric and high-ferrous iron contents of ore, (3) the decrease of ferric iron toward the edge of the altered tongue, and (4) the similarity between total-iron contents of altered and unaltered sandstone. 

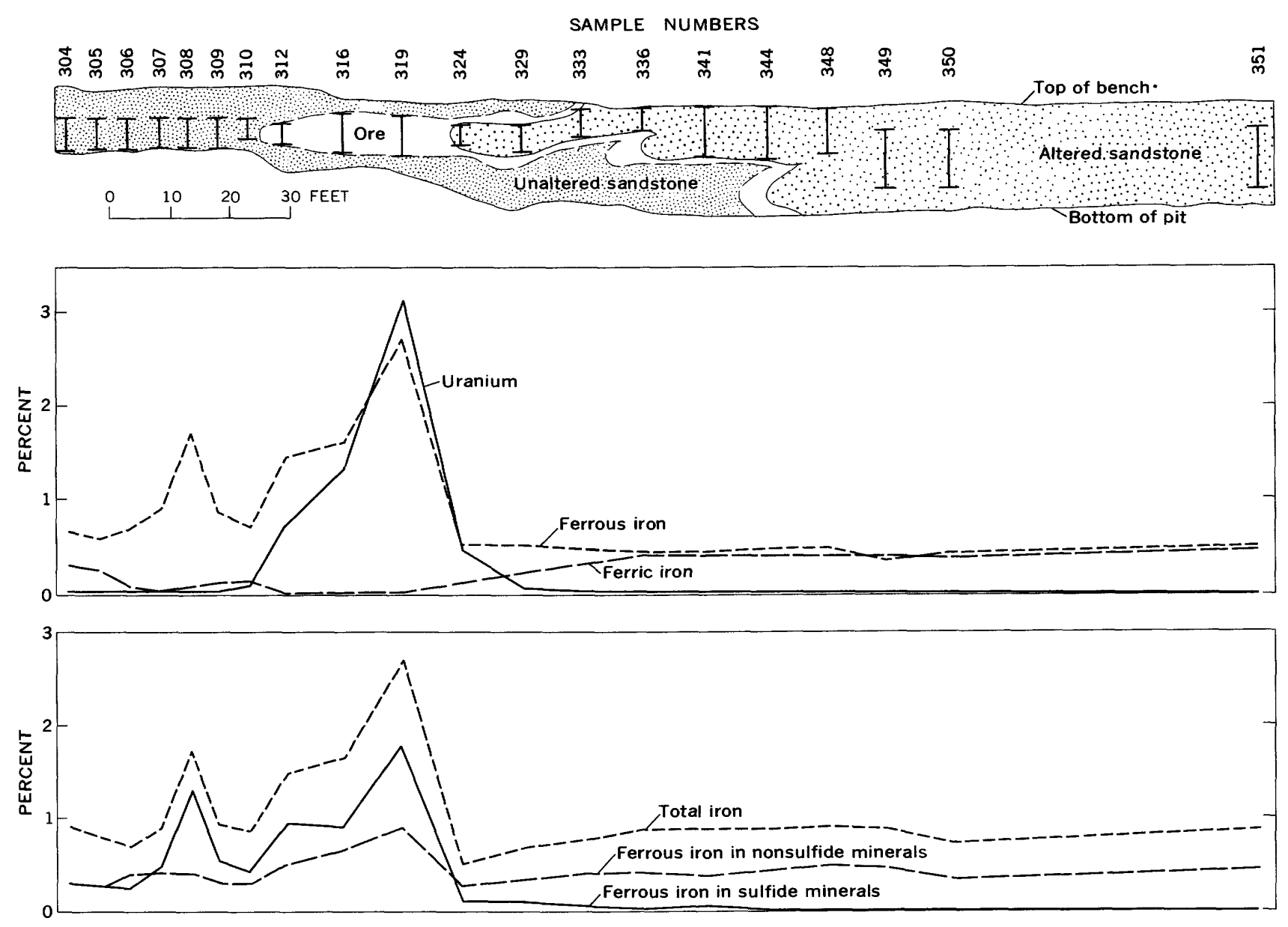

Figure 45. - Section through ore body in Petrotomics Co. Section 9 pit, showing locations of samples and the distribution of uranium, of ferrous, ferric, and total iron, and of ferrous iron in sulfide and nonsulfide minerals.

\section{SELENIUM}

Selenium in amounts of more than $100 \mathrm{ppm}$ is found only in a narrow zone, generally less than 5 feet wide, astride the contact of ore and altered sandstone. Samples from this zone contain as much as $3,000 \mathrm{ppm}$ (0.3 percent) selenium. The highselenium zone is not necessarily symmetrical with respect to the contact, and the greatest amount of selenium may be either in ore or in altered sandstone. The selenium content of ore and of altered sandstone decreases abruptly away from the contact. High-grade ore and altered sandstone generally contain, respectively, $2-10$ and $10-50 \mathrm{ppm}$ selenium 10-20 feet from the contact. In small or low-grade deposits the amount of selenium decreases in much shorter distances.

Unaltered sandstone contains $1 / 2-1 \mathrm{ppm}$ selenium, probably in the crystal lattice of the pyrite. In sharp contrast, altered sandstone farther from the edge of the tongue contains $10-40 \mathrm{ppm}$ selenium. Here the selenium is thought to be associated with the limonite or goethite.

Figure 46 shows the distribution of selenium across a small ore body in the Shirley Basin.

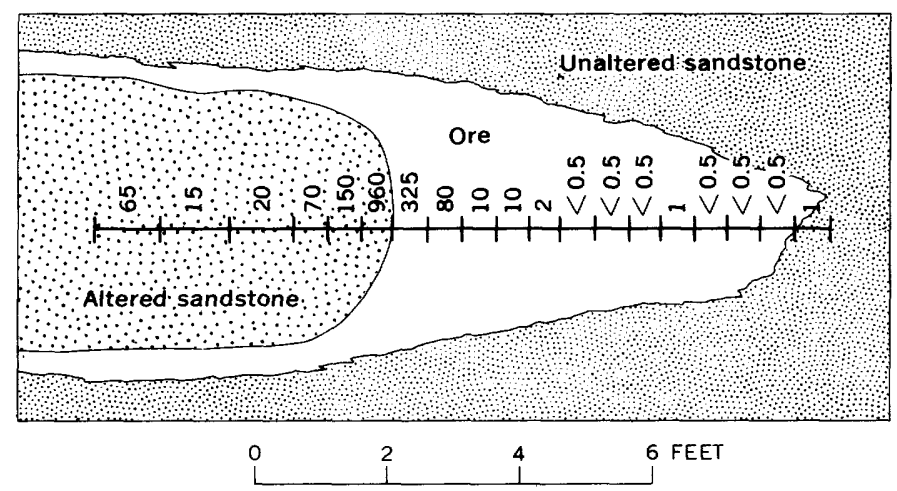

FIGURE 46. - Section through ore body in Utah Construction and Mining Co. mine, showing locations of samples and their selenium contents, in parts per million. 
SUlfate

Significant differences in the sulfate content of altered sandstone, unaltered sandstone, and ore are shown by analytical data on sample suites across uranium deposits in the Shirley Basin. Samples of altered sandstone from the Utah Construction and Mining Co. mine and from the Petrotomics Co. Section 9 pit contain $0.03-0.09$ percent sulfate. Samples of unaltered sandstone from both workings contain 0.04-0.30 percent sulfate. In the altered sandstone the sulfate-bearing mineral or minerals are not known, but in unaltered sandstone some of the sulfate is present as gypsum.

Most of the uranium ore contains from a few hundredths to a few tenths of a percent sulfate, but one sample from a roll in the Petrotomics Co. Section 9 pit contained 3.33 percent. This ore sample (319), when leached in 150 cubic centimeters of distilled water for 10 hours on a steam bath $\left(95^{\circ} \mathrm{C}\right)$ gave rise to a filtrate of $\mathrm{pH} 4$, saturated with calcium sulfate and enriched in iron. Analytical data are inconclusive on possible elements combined with sulfate in the ore, and polished sections of ore contain no identifiable sulfate mineral. The presence of a ferrous sulfate compound is suspected. The sulfate contents of samples from two rolls are shown in figure 47 .

There is no positive correlation between the amount of sulfate and other elements, including uranium, in the sample suites, although sandstone high in uranium generally is relatively high in sulfate. The amount of sulfate in altered sandstone is generally less than that in either ore or unaltered sandstone, but the $\mathrm{U} / \mathrm{SO}_{4}$ ratios in both unaltered and altered sandstone are much less than 1 . The same ratio in ore is generally more than 1 . This contrasts with the findings in the Gas Hills by King and Austin (1966, p. 79), who stated that "a low uranium value and a $\mathrm{U}_{3} \mathrm{O}_{8} / \mathrm{SO}_{4}$ ratio of greater than or near unity would indicate a sample from the barren interior."

\section{Carbon}

Carbon is present in the ore bodies in two principal forms-as mineral carbon in calcium carbonate and as organic carbon in fossil plant debris. Figure 48 shows the distribution of mineral and organic carbon and manganese in an ore body in the Petrotomics Co. Section 9 pit. In this sample suite, as in others from the Shirley Basin, altered sandstone contains much less organic carbon than does unaltered sandstone or ore. Also in this suite, the sample with the most uranium contains the most organic carbon, a relation that does not persist throughout the basin: although some samples of high-grade ore contain considerable organic carbon, others are low in organic carbon, and many samples high in organic carbon contain insignificant amounts of uranium.

Mineral carbon, as calcite cement, is present in concretionary masses in ore and in unaltered sandstone in a halo around ore. The distribution of calcite was discussed under "Mineralogy and Mineral Distribution."

\section{MANGANESE}

Manganese distribution in a typical ore body is shown in figure 48. Manganese contents range from 70 to $2,000 \mathrm{ppm}$, and there is little or no concentration of this element in the ore. However, there appears to be a good correlation between manganese and calcite, for almost without exception samples high in mineral carbon, be they from ore, altered sandstone, or unaltered sandstone, are high in manganese.

\section{Phosphate}

Samples from the Shirley Basin deposits contain from a few hundredths to as much as 0.11 percent $\mathrm{P}_{2} \mathrm{O}_{5}$. High phosphate generally accompanies high uranium, but the correlation is not direct, for the $\mathrm{U} / \mathrm{P}_{2} \mathrm{O}_{5}$ ratios range from 28.0 in the highest grade ore to 0.02 in weakly mineralized sandstone. Both altered and unaltered sandstone contain about 0.05 percent $\mathrm{P}_{2} \mathrm{O}_{5}$. The phosphate-bearing mineral or minerals have not been identified, but the wide variation in the $\mathrm{U} / \mathrm{P}_{2} \mathrm{O}_{5}$ ratios and the fact that the amount of phosphate exceeds that of uranium by two orders of magnitude in altered and unaltered sandstone indicates that a significant amount of phosphate is not contained in uranium-bearing minerals.

The uranium and phosphate contents and the $\mathrm{U} / \mathrm{P}_{2} \mathrm{O}_{5}$ ratios of the samples shown in figure 45 are listed in table 7 .

TABLE 7.-Uranium and phosphate contents and $\mathrm{U} / \mathrm{P}_{2} \mathrm{O}_{5}$ ratios for a suite of samples from the Petrotomics Co. Section 9 pit

[Locations of samples are shown, by sample number, in fig. 45]

\begin{tabular}{|c|c|c|c|}
\hline Sample & $\begin{array}{c}\text { Uranium } \\
\text { (percent) }\end{array}$ & $\underset{\text { (percent) }}{\mathrm{P}_{2} \mathrm{O}_{5}}$ & $\mathrm{U} / \mathrm{P}_{2} \mathrm{O}_{5}$ ratio \\
\hline 304 & 0.002 & 0.067 & 0.03 \\
\hline 305 & .002 & .051 & .04 \\
\hline $\begin{array}{l}306 \\
307\end{array}$ & .001 & .051 & .02 \\
\hline $\begin{array}{l}307 \\
308\end{array}$ & $\begin{array}{l}.001 \\
.002\end{array}$ & $\begin{array}{r}.043 \\
.043\end{array}$ & .02 \\
\hline 309 & .001 & .045 & .02 \\
\hline 310 & .075 & .066 & 1.14 \\
\hline 312 & .72 & .084 & 8.57 \\
\hline 316 & 1.30 & .046 & 13.54 \\
\hline 319 & 3.07 & .110 & 27.91 \\
\hline $\begin{array}{l}324 \\
329\end{array}$ & .45 & .077 & $\begin{array}{l}5.84 \\
1.59\end{array}$ \\
\hline 333 & .010 & .041 & .24 \\
\hline 336 & .006 & .083 & .07 \\
\hline 341 & .006 & .050 & .12 \\
\hline 348 & .007 & .050 & .14 \\
\hline 349 & .002 & .050 & .04 \\
\hline $\begin{array}{l}350 \\
351\end{array}$ & .001 & .051 & .02 \\
\hline
\end{tabular}



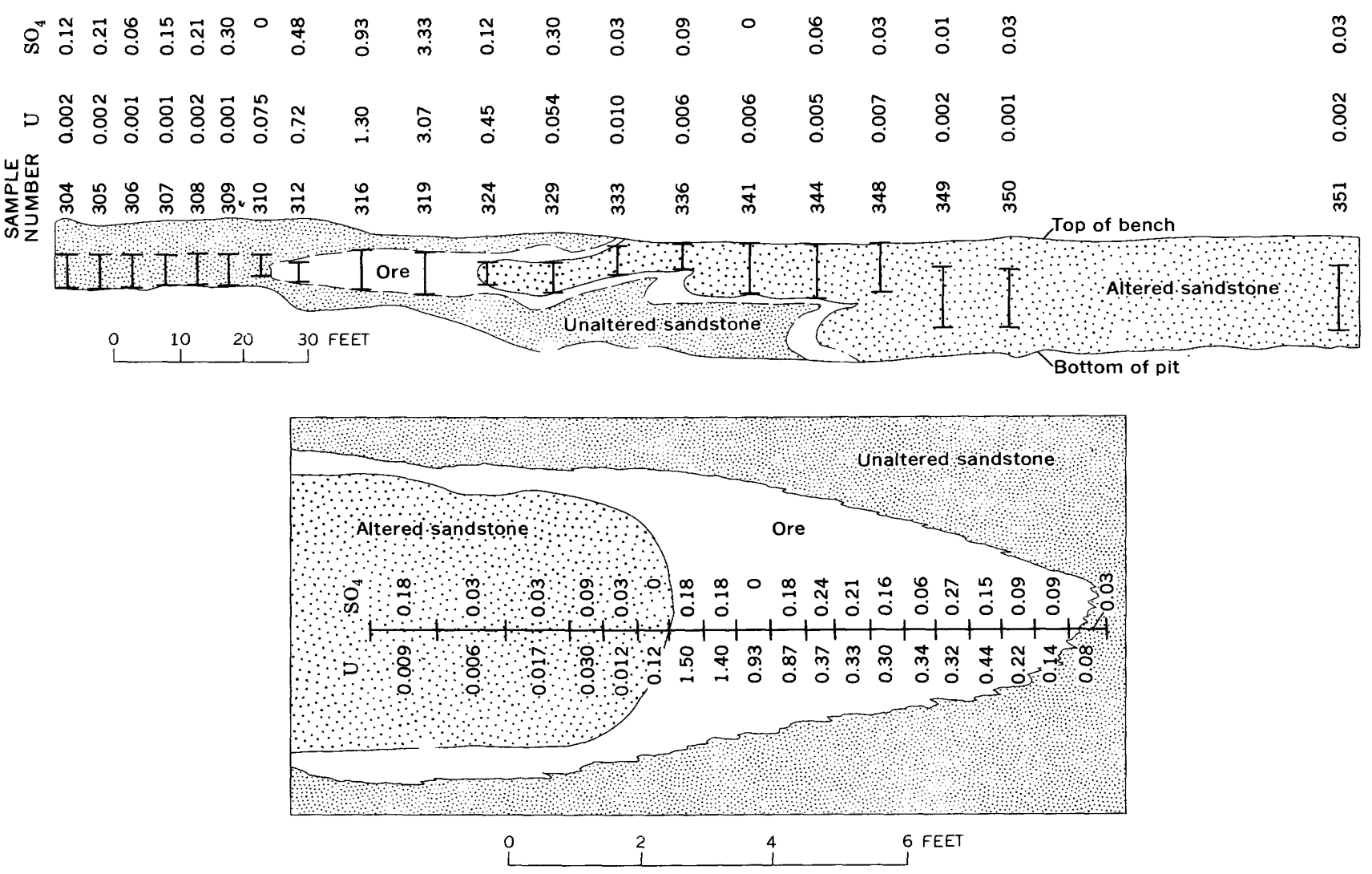

FigURE 47. - Sections through ore rolls in Petrotomics Co. Section 9 pit (upper) and in the Utah Construction and

Mining Co. mine (lower), showing locations of samples and their uranium and sulfate contents, in percent.
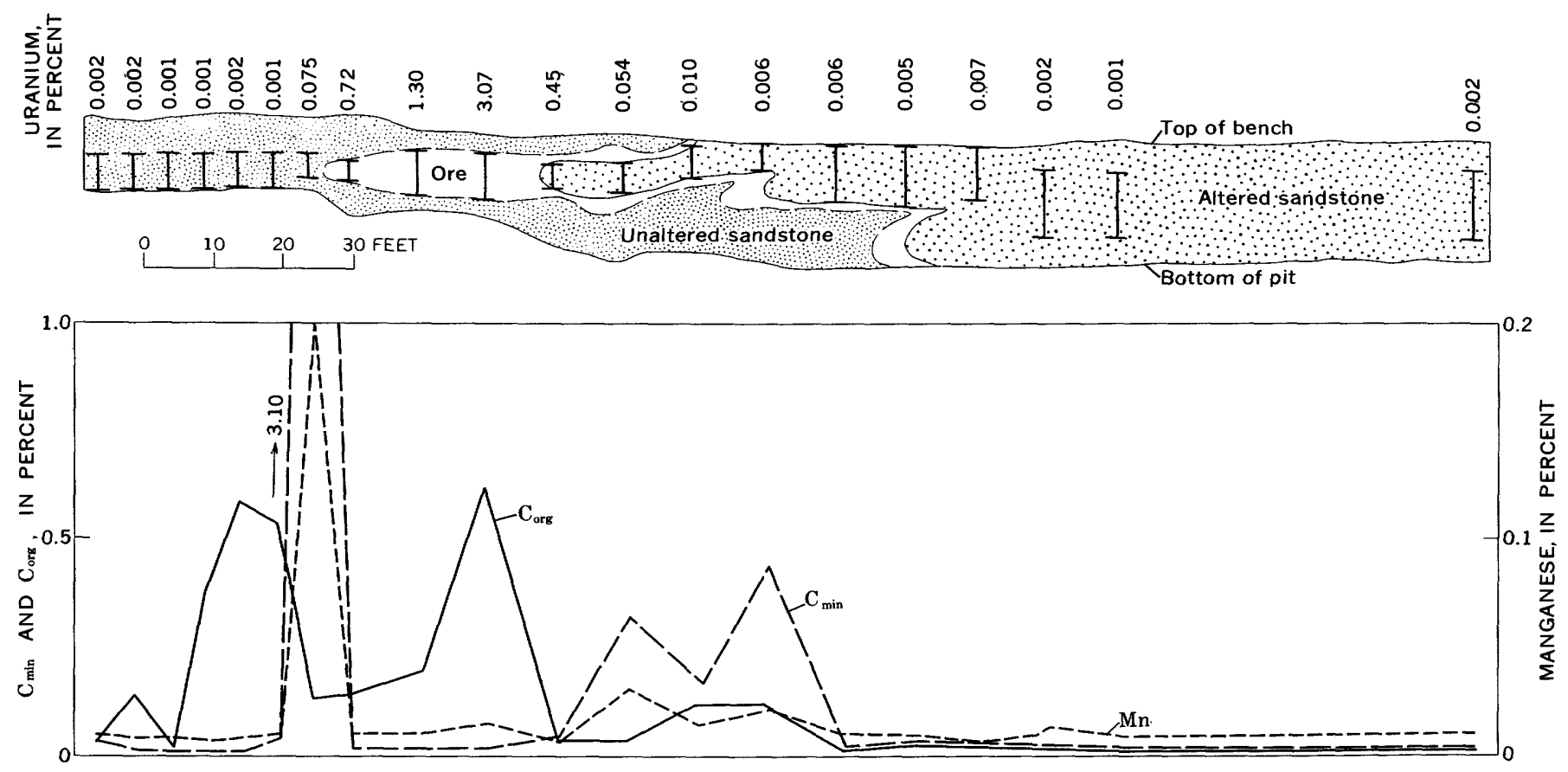

Figure 48. - Section through ore body in Petrotomics Co. Section 9 pit, showing locations of samples and their organiccarbon $\left(\mathrm{C}_{\mathrm{org}}\right)$, mineral-carbon $\left(\mathrm{C}_{\mathrm{min}}\right)$, and manganese $(\mathrm{Mn})$ contents. 
ARSENIC

The arsenic and uranium contents of a suite of samples from an ore body in the Petrotomics Co. Section 9 pit are shown in figure 49 . Arsenic ranges from 30 to $50 \mathrm{ppm}$ in ore-grade material; it averages about $5 \mathrm{ppm}$ in unaltered sandstone and less than $1 \mathrm{ppm}$ in altered sandstone. In this ore body, the distribution of arsenic correlates well with that of sulfide sulfur, less well with that of uranium, and not at all with that of selenium.

Arsenic in a suite of samples across an ore body in the Utah Construction and Mining Co. mine shows a fair correlation with uranium, a lack of correlation with selenium, and only a fair correlation with sulfide sulfur. Altered sandstone in this suite contains $2-5 \mathrm{ppm}$ arsenic, and ore having as much as 0.30 and 0.41 percent sulfide sulfur contains only 1 ppm arsenic-considerably less than in the Petrotomics Co. ore body in sec. 9. The distribution of arsenic in the Shirley Basin deposits suggests that some of the arsenic is contained in pyrite and that some also may be associated with other minerals.

CoPPER

The distribution of copper has been determined from analyses of several hundred samples from ore bodies in the Utah Construction and Mining Co. mine and in the Petrotomics Co. Section 9 pit. Spectrographic analyses, having a threshold detection limit of $1 \mathrm{ppm}$, indicate that altered sandstone contains 2-7 ppm copper; the larger amounts are within a few feet of the edges of the altered tongues, and the smaller amounts are farther from the edges. Ore and unaltered sandstone contain from a few to as much as $20 \mathrm{ppm}$ copper and an average of about $10 \mathrm{ppm}$. The copper contents of a typical roll are shown in figure 50.

On the basis of available data, it seems probable that the ore-bearing solutions leached copper from the altered sandstone but did not redeposit it within the ore bodies.

\section{VANADIUM}

Most of the uranium deposits in the Tertiaryfilled basins of Wyoming contain little vanadium; the Shirley Basin is no exception. The highest grade ore samples contain about 0.15 percent vanadium and have $\mathrm{U} / \mathrm{V}$ ratios as high as $100: 1$, although in much of the ore, uranium exceeds vanadium by a factor of 20-25. The vanadium content of altered sandstone near the margins of the tongues is 100 $150 \mathrm{ppm}$, but it drops rapidly away from the margins to $15-50 \mathrm{ppm}$. $\mathrm{U} / \mathrm{V}$ ratios in altered sandstone range from about $20: 1$ near the margins of the tongues to about $0.5: 1$ away from the margins.

Unaltered sandstone contains $15-50 \mathrm{ppm}$ vanadium, about the same as altered sandstone away from the margins of the tongue. $U / V$ ratios in unaltered sandstone, similar to those in altered sandstone away from the margin of the tongues, range from $0.5: 1$ to $1: 1$.

The vanadium contents of samples across a typical roll in the Petrotomics Co. Section 9 pit are shown in figure 50.

\section{BERYLLIUM}

The maximum beryllium content of any analyzed sample of sandstone from the Shirley Basin is 3 ppm in a sample of high-grade ore; most samples contain $1.5 \mathrm{ppm}$ or less beryllium.
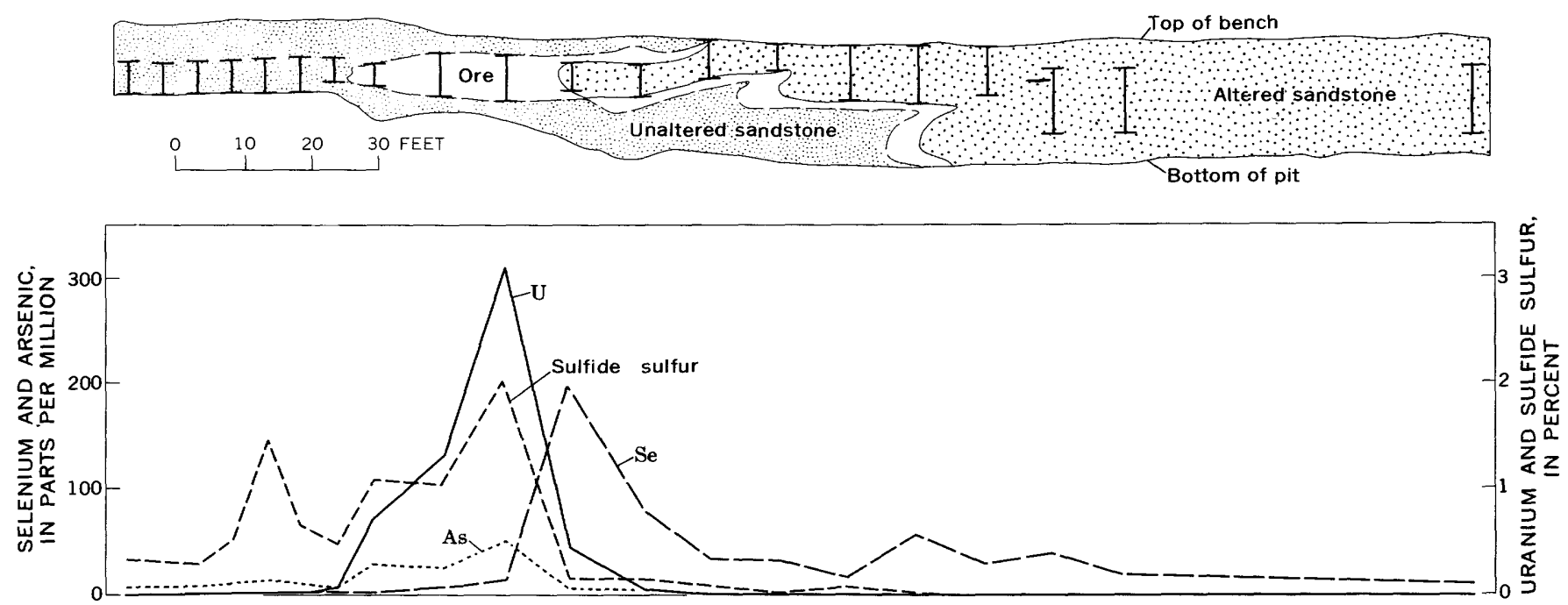

FIgURE 49. - Section through ore body in Petrotomics Co. Section 9 pit, showing locations of samples, and their uranium, selenium, arsenic, and sulfide-sulfur contents. 

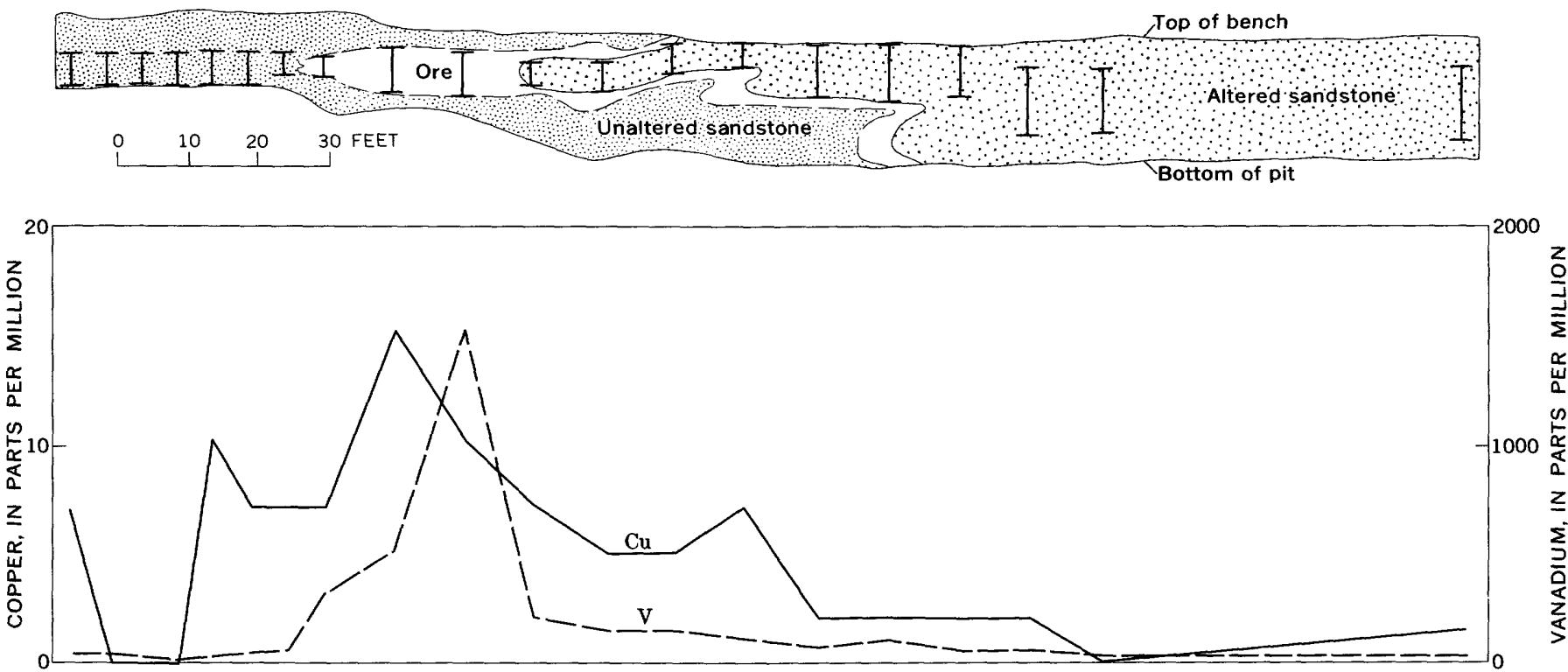

Figure 50. - Section through ore body in Petrotomics Co. Section 9 pit, showing locations of samples and their copper and vanadium contents.

Spectrographic analyses of 180 samples of sandstone from the Utah Construction and Mining Co. mine and Petrotomics Co. Section 9 pit show beryllium as not detectable (less than $1 \mathrm{ppm}$ ) in all 42 unaltered-sandstone samples, detectable in only two of 53 altered-sandstone samples, but, in sharp contrast, detectable in 30 of 85 ore samples. Statistically, there seems to be little doubt that beryllium was transported and deposited with uranium from the ore-bearing solutions.

\section{LEAD}

Spectrographic analyses on 86 ore samples, 42 unaltered-sandstone samples, and 52 altered-sandstone samples show that lead contents are considerably higher in ore than in altered and unaltered sandstone. Ore samples that contain $0.10-19.2$ percent uranium correspondingly contain 0.0015-0.02 percent lead; their average lead content is 0.0051 percent. A suite of 15 ore samples, all containing more than 2 percent uranium and averaging 4.83 percent uranium, contains an average of 0.0122 percent lead. It is apparent that the highest lead contents are paired with the highest uranium contents.

The analyses show almost no difference in the lead contents of altered and unaltered sandstone. Altered sandstone contains $15-30 \mathrm{ppm}$ lead and averages $16 \mathrm{ppm}$. Unaltered sandstone contains $10-$ $20 \mathrm{ppm}$ lead and averages $15 \mathrm{ppm}$.

Undoubtedly most of the lead results from inplace radioactive decay of $\mathrm{U}^{235}, \mathrm{U}^{238}$, and thorium, but some common lead and radiogenic lead may have been transported to the site of deposition by the ore-bearing solution.

MERCURY

Mercury analyses, sensitive to $5 \mathrm{ppb}$, were made by the atomic-absorption method on a suite of 24 samples from the ore roll shown in figure 50. Unaltered sandstone contains an average of $36 \mathrm{ppb}$ mercury (range 30-50 ppb); altered sandstone, an average of $40 \mathrm{ppb}$ (range $20-70 \mathrm{ppb}$ ); and ore, an average of $37 \mathrm{ppb}$ (range $30-40 \mathrm{ppb}$ ). These differences are insignificant, and at this locality at least, there is no mercury halo associated with a large high-grade uranium ore body.

Miscellaneous Elements

Analytical data on elements, other than those just discussed, are not conclusive with respect to correlation with other elements or distribution in the roll features. Barium may be slightly more abundant in the ore than in unaltered sandstone $(0.133$ versus 0.091 percent), and barite crystals with high alpha activity have been observed associated with carbonized plant debris in the Utah Construction and Mining Co. mine. Some of the rock-forming elements, particularly potassium and sodium, may be depleted in the ore, but this apparent depletion is probably due to dilution by the addition of elements such as uranium, iron, and calcium to the ore-bearing sandstone. 


\section{GEOCHEMISTRY}

An acceptable concept of origin for the Shirley Basin uranium deposits must explain their restricted stratigraphic distribution, their spatial relations to large bodies of altered sandstone, the systematic distribution of their component minerals, and their physical parameters. It must encompass the source of the uranium and associated elements, the nature and hydrodynamics of the ore-bearing fluid, the method of precipitation of the ore minerals, and the disposition of the spent ore fluid. Because the ore bodies were formed eons ago, any discussion of their origin is speculative and interpretative. There is, however, a large body of data on the Shirley Basin deposits that can be used to keep speculation within reasonable bounds and, it is hoped, to help interpret correctly some of the complex factors pertinent to genesis of the deposits.

The ore bodies are clearly epigenetic, as shown by the fact that parts of most of them cut the host sandstone beds at sharp angles. In a few places the ore minerals are distributed along the crossbeds, and in these places the ore gives the false impression of being syngenetic. Figures 32 and 33 show ore that cuts across bedding as well as ore that "pseudomorphs" bedding.

Unfortunately, evidence is much less clear as to the source of the uranium now concentrated in the deposits, the character of the solutions that transported the uranium, and the reasons for uranium deposition in the ore bodies. Possible sources of the uranium and associated elements in the Shirley Basin deposits are (1) magmatic hydrothermal solutions, (2) the arkosic Wind River sandstone that is the host for the deposits, (3) the granite in the cores of the mountain ranges that flank the basin, and (4) the White River and younger formations, which overlie or once overlay the area, and more particularly the tuffaceous components of these rocks.

Magmatic hydrothermal solutions appear to be the least likely source of the elements in the ore inasmuch as no evidence of hydrothermal activity of Tertiary age exists in or near the basin, no igneous activity of Tertiary age is known within 50 miles of the basin, and no deposits of probable hydrothermal origin and Tertiary age occur in the mountain ranges that flank the basin. Possibly some contribution of elements to the ore-bearing solution was made by the intermixing of ground water and magmatic fluids, but it is unlikely that such contributions were significant.

The arkosic material that forms the permeable, ore-bearing part of the Wind River or Wasatch
Formation has been considered by some geologists (Melin, 1964; Rackley and others, 1968) to be the source of the uranium and other elements in some of the Wyoming deposits. Data on the ore, altered sandstone, and unaltered sandstone in the Shirley Basin, much of which is given in an earlier section of this report, indicate that this was not the source for these deposits. The uranium content of the altered sandstone in the Shirley Basin is slightly greater than that of the unaltered sandstone, an impossible situation if the altered arkose were the source of uranium in the ore bodies. Furthermore, in the Shirley Basin as in the Gas Hills, the altered sandstone contains 10-50 times more selenium than does the unaltered sandstone, which is clear evidence that the arkose is not the source of the selenium in the deposits and suggestive that it was not the source of the uranium so intimately associated with selenium.

Samples of granitic rocks from the cores of the Laramie and Shirley Mountains, rocks considered to be the sources of the arkoses in the Shirley Basin, contain several parts per million uranium, some of which is shown by laboratory tests to be loosely held and readily available for solution by percolating water. One sample of gabbro and 11 of granite were crushed to about one-eighth inch in order to separate, but not grind, the component mineral grains. Five grams of the crushed material was placed in a funnel, and $50 \mathrm{ml}$ (milliliters) of a leach solvent was dripped through it in a 10-hour period. The solvent was similar to present-day Shirley Basin ground water; it contained $0.3 \mathrm{~g}$ (grams) of $\mathrm{Na}_{2} \mathrm{SO}_{4}$ and $0.15 \mathrm{~g}$ of $\mathrm{Na}_{2} \mathrm{CO}_{3}$ in 1 liter of water, and it was brought to a pH of 7.98 by the addition of $\mathrm{CO}_{2}$. The results of the experiment are shown in table 8 .

TABLE 8. - Uranium leached from samples of igneous rocks from mountain ranges that flank the Shirley Basin

[...., not calculated because value for ppm leached uranium is not precise

\begin{tabular}{|c|c|c|c|}
\hline \multirow{3}{*}{ Sample } & & & \\
\hline & \multirow{2}{*}{$\begin{array}{l}\text { Total uranium } \\
\text { (ppm) }\end{array}$} & \multicolumn{2}{|c|}{ Leached uranium } \\
\hline & & ppm & percent \\
\hline \multicolumn{4}{|c|}{ Granite } \\
\hline 85 & 7.0 & 0.039 & 0.6 \\
\hline 86 & 2.0 & .008 & .4 \\
\hline 87 & 1.0 & .009 & .9 \\
\hline $88 \mathrm{a}$ & 2.0 & .005 & .2 \\
\hline $88 \mathrm{~b}$ & 2.0 & .010 & .5 \\
\hline 89 & 1.5 & .008 & .5 \\
\hline 90 & .5 & $<.005$ & 77 \\
\hline $\begin{array}{r}91 \\
160\end{array}$ & $\begin{array}{r}1.0 \\
.2\end{array}$ & $<.005$ & \\
\hline $\begin{array}{l}160 \\
161\end{array}$ & 3.0 & $\begin{array}{l}.027 \\
\end{array}$ & 9.9 \\
\hline 162 & $\begin{array}{r}.4 .0 \\
\end{array}$ & $<.005$ & \\
\hline \multicolumn{4}{|c|}{ Gabbro } \\
\hline 163 & 0.4 & $<0.005$ & $\ldots$ \\
\hline
\end{tabular}

The period of contact between the solvent and the crushed granite was short, yet as much as 0.9 percent of the uranium was leached from material containing a few parts per million uranium. These tests indicate that readily soluble uranium was 
available to ground water early in the weathering of granite, and it probably was removed; the uranium remaining in the arkose after its deposition in the basin possibly was quite insoluble and in large part unavailable for solution by ground water. It seems probable, therefore, that the granite, as it weathered in place, was a source of some of the uranium in the Shirley Basin deposits, but the importance of this particular source is not known.

Volcanic ash has been considered by many to be a source of copper, uranium, selenium, and some other elements in sedimentary rocks and soils. As early as 1938, Koeberlin proposed that "red bed" type deposits of copper, vanadium-uranium, and silver were formed by the leaching of these metals from volcanic ash, transportation by ground water to shallow basins, and precipitation by the reducing action of organic matter or bacteria. Beath (1943) implied that uranium, selenium, and other metals in sandstone deposits in the Yellow Cat area of Utah were of volcanic origin, and Beath, Hagner, and Gilbert (1946) related the high selenium content of some Wyoming soils to the high selenium content of tuffaceous beds in the Tertiary rocks of Wyoming. Denson, Bachman, and Zeller (1951) proposed that uranium associated with lignite in North Dakota and South Dakota was leached from the tuffaceous White River Formation, and Love (1952) concluded that the uranium in the deposits he discovered in the Powder River Basin was deposited from descending vados water that had leached uranium from the overlying White River Formation. Many earth scientists have proposed similar origins for the metals in sandstone-type uranium deposits.

The tuffaceous rocks of the White River and younger formations that overlie, or once overlay, the Shirley Basin area probably were the source of some of the elements in the ore deposits. Water that was taken from springs at the base of the upper member of the White River Formation and that has not been in contact with other rocks contains 8-10 $\mathrm{ppb}$ uranium, and water from springs near the base of the lower member, where tuffs predominate, contains 19-52 ppb uranium. These data show that the White River Formation is contributing uranium to the present-day ground water, so these rocks must be considered as a probable source of some of the uranium in the Shirley Basin ore deposits.

The source of the uranium being leached from the White River Formation is not definitely known, but there is reason to believe that much of it comes from the tuffaceous rather than the clastic fraction of the rock, although both fractions contain 5-10 ppm uranium. Lipman (1965) reported that volcanic glass, upon hydration, looses certain constituents to circulating water, particularly sodium and silica. It is possible that uranium, as well as silica and calcium, may be lost. There are no data on the extent to which the clastic fraction of the tuffaceous rocks contribute constituents to ground water, but it seems probable that uranium and associated elements are contained in quartz, feldspar, and heavy minerals, such as zircon, or they may be absorbed on clays, and thus the contribution of the clastic fraction is probably small.

The cited evidence as to the source of the uranium and associated elements in the Shirley Basin ore deposits is circumstantial, but it does suggest that the source was multiple and included the granitic rocks in the cores of the mountains that flank the basin as well as the tuffaceous fraction of the White River and younger formations that overlie or once overlay the area.

SOLUTION, TRANSPORTATION, AND DEPOSITION OF ELEMENTS

Hostetler and Garrels (1962) showed that in the presence of $\mathrm{CO}_{2}$ and at low temperatures and pressures, uranium is soluble in either the 4- or the 6-valent state, depending on the $\mathrm{pH}$ and $\mathrm{Eh}$ of the solution. Transportation in the 4-valent state is possible at Eh values of about +0.3 volt or less and at $\mathrm{pH}$ values of less than about 3 . Transportation in the 6 -valent state is possible in acidic or alkaline solutions at minimum Eh values of about +0.3 and -0.4 volt. The amount of $\mathrm{CO}_{2}$ in solution affects the solubility of uranium and the limits of $\mathrm{pH}$ and Eh values at which it is easily transported. The wide range of conditions under which uranium is soluble makes this element a poor indicator of the character of the transporting medium and the genetic processes responsible for the Shirley Basin deposits. However, other factors such as the geochemical environment of the basin, the character of alteration produced by the ore-bearing solutions, and the geochemistry of elements associated with uranium greatly restrict the conditions under which the deposits could have been formed.

The permeable part of the Wind River Formation, in which the uranium deposits are found and through which the ore-bearing solution migrated, is an arkose containing considerable orthoclase and microcline, some plagioclase, 1-5 percent acid-soluble material (mostly calcium carbonate), and 50 percent or more quartz. The White River and Arikaree Formations that overlie, or once overlay, the Wind River have clastic components similar to those in 
the Wind River, but in addition they contain considerable volcanic ash in the form of fairly pure tuff beds or as glass shards dispersed through siltstones. Both the arkosic and the tuffaceous rocks are alkaline and would tend to buffer the $\mathrm{pH}$ of ground water flowing through them. Garrels and Christ (1965) showed that water in contact with $\mathrm{CaCO}_{3}$ generally has a $\mathrm{pH}$ of 8 or more, the exact value depending on the partial pressure of $\mathrm{CO}_{2}$ in the system and other factors. Hemley and Jones (1964) discussed at length the increase in alkalinity caused by the hydrolysis of silicate minerals such as feldspar. Laboratory and theoretical data show that alteration of silicic glass releases silica and alkali ions to ground water and produces $\mathrm{pH}$ values of 8 or more (Hay, 1963). The theoretical considerations are confirmed by the $\mathrm{pH}$ measurements of actual ground water in the Shirley Basin (table 2), where 39 of 40 water samples from the Tertiary rocks have $\mathrm{pH}$ values greater than 7.0 ; the average of the 40 samples is 7.7 , and the median is about 7.75 .

Ground water flowing through the basin today is alkaline, and the environment through which it flows is conducive to alkalinity, so if the present is a key to the past, it seems reasonable to conclude that the ore-bearing solutions were alkaline.

Transportation of elements in oxidizing solutions is suggested by the character of the alteration produced as the solutions passed through the ore-bearing sandstone. Pyrite is present in the unaltered sandstone in amounts approaching 1 percent, but in altered-sandstone tongues a few tens of feet from their edges it has been almost totally removed (total sulfur is less than 0.02 percent). Carbonaceous trash sparingly distributed through the unaltered sandstone has been almost completely destroyed in the altered sandstone, both visually and chemically. Goethite and limonite are present in some samples of altered sandstone, but not in unaltered sandstone. $\mathrm{Fe}^{+2} / \mathrm{Fe}^{+3}$ ratios in altered sandstone are about $1: 1$ or less, but in unaltered sandstone they are at least $2: 1$; total-iron contents of the two types of sandstone are similar. These data suggest that the ore-bearing solutions were oxidizing with respect to iron and carbon.

Oxidizing alkaline ore-bearing solutions are suggested by the geochemistry of the ore elements at low temperatures and pressures. Selenium appears to be one of the most diagnostic elements with respect to character of the solution in which it moved. It is intimately associated with ore and must be considered as having been deposited with uranium from the ore-bearing solutions. Data summa- rized by Lakin (1961) show that, under conditions extant in natural environments, selenium can be taken into solution and transported only under oxidizing alkaline conditions. Although the selenite ion $\left(\left(\mathrm{Se}_{2} \mathrm{O}_{3}\right)^{-2}\right)$ is readily formed under moderate oxidation potentials in either acid or alkaline solutions, it is almost immediately immobilized by reacting with the ferric ions in ground water to form an insoluble precipitate having a composition approximating a basic ferric selenite. Selenate ion is soluble in most natural waters, but it is formed only under restricted $\mathrm{Eh}$ and $\mathrm{pH}$ conditions. In acid solutions selenate ion is formed only under conditions of acidity far greater than can be expected in the most rigorous natural environments. However, in solutions of about $\mathrm{pH} 7$ and greater, the oxidation potentials in near-surface waters will oxidize selenium to selenate, and probably solutions of this character dissolved and transported the selenium in the Shirley Basin deposits. Selenium possibly migrates in ground water as a complex with sulfur (Goleva and Lushnikov, 1967) rather than as selenate ion. Laboratory investigations of this method of selenium transport and the implications with respect to uranium deposits in sandstones indicate that the complexes are stable in alkaline oxidizing solutions and unstable in acid reducing solutions (Warren, 1968; Granger and Warren, 1969).

The distribution of beryllium, discussed earlier in this report, indicates it was a component of the ore-bearing solution. The geochemistry of this element at low temperatures and pressures is not well known, but Beus (1962) suggested that it is transported in alkaline solutions as a complex with chlorine, fluorine, or carbonate. Govorov and Stunzhas (1963) showed that alkalic carbonatoberyllate complexes are stable in the $\mathrm{pH}$ range 6.8 to 11.8 at temperatures of about $80^{\circ}-210^{\circ} \mathrm{C}$ and that a decrease in the alkalinity of the solvent causes precipitation of beryllium compounds. These data suggest that beryllium was transported in alkaline solutions, but they do not preclude transportation in solutions of other character.

In addition to the positive, though indirect, evidence that the ore-bearing solutions were alkaline and oxidizing, there is evidence that they were not acid. Acidic solutions, particularly if they were sufficiently acid $(\mathrm{pH}<3)$ to transport uranium in the 4-valent state and if they percolated through the ore-bearing arkosic members of the Wind River Formation in sufficient volume to account for the uranium deposits in the Shirley Basin, would have produced considerable alteration of feldspar minerals, particularly plagioclase. Alteration of feldspar 
in the thin sections of the rocks in the altered-sandstone tongues is minimal and can be accounted for by a temporary acidic "front" produced by oxidation of pyrite in the ore body, a process described later in this report.

A second major objection to the ore-bearing solutions being acid is the difficulty of generating them in great volume and over a considerable period of time. A magmatic source of acid emanations seems unlikely for reasons discussed earlier. Oxidation of pyrite produces sulfuric and carbonic acid, but available data show that more than enough carbonate ( $>2.5$ percent) is present in the Wind River Formation to neutralize the acid produced by oxidation of the small content of pyrite ( $1 \pm$ percent). Carbonized plant material in the arkosic sandstone seems too sparse for one to postulate that the ore-bearing solutions contained large amounts of humic acids, and there are difficulties in transporting uranium and associated elements in solutions made acid by humic compounds.

The data presented in the preceding paragraphs weigh heavily in favor of the supposition that the ore-bearing solutions were neutral to somewhat alkaline and oxidizing with respect to iron, selenium, uranium, carbon, and associated elements.

The ore deposits appear to have resulted from a reduction in the $\mathrm{Eh}$ of the transporting fluid, although a drop in $\mathrm{pH}$ may have been a contributing factor in their formation. The large amount of ferrous iron and the small amount of ferric iron in the ore, the presence of ferroselite in ore and in altered sandstone near ore, the reduced chemical state of the ore minerals, and the general nature of the environment in which ore is found, all topics discussed earlier in this report, suggest that the zone of deposition was strongly reducing with respect to the ore elements. The nature of the reductant is not known. Lindgren, Graton, and Gordon (1910) postulated that the red-bed copper deposits of New Mexico might have originated through reduction of copper by $\mathrm{H}_{2} \mathrm{~S}$ of biogenic origin. More recently Jensen (1958), Cheney and Jensen (1966), and others theorized that $\mathrm{H}_{2} \mathrm{~S}$ of biogenic origin accounts for the sulfur in the pyrite intimately associated with uranium in the Wyoming deposits. Research now under way in the U.S. Geological Survey (Granger and Warren, 1969) shows that pyrite associated with uranium ore may form in the absence of bacteria by inorganic reactions between iron and several dissolved sulfur-bearing compounds formed by oxidation of disseminated pyrite of biogenic origin. Bacterial reduction of sulfate is essential to this concept, but the final re- duction of the elements to form ore is independent of bacterial activity.

Grutt (1957) proposed that natural gas may have been the reductant for the ore deposits in the Gas Hills area of Wyoming. The Wall Creek Sandstone Member of the Frontier Formation underlies the ore-bearing areas of the Shirley Basin and contains oil and gas in some parts of Wyoming. Where the western and southern edges of the lower alteredsandstone tongue pass over the Wall Creek, there is no noticeable increase in the amount or grade of ore above the paleooutcrop, and it seems unlikely therefore that gas escaping from this sandstone was the reductant for these deposits.

Organic matter in situ, and perhaps redistributed organic compounds not recognized in this investigation, may have been the loci for deposition of some uranium and pyrite. However, the poor correlation between carbon and uranium, discussed in an earlier section of this report, suggests that carbon itself has not played an important roll in the formation of the deposits.

Although available data do not define the reductant responsible for the uranium deposits in the Shirley Basin, they are compatible with the concept that $\mathrm{H}_{2} \mathrm{~S}$ of biogenic origin was an important factor in ore genesis, either directly or through intermediate sulfur compounds formed by oxidation of an early biogenic pyrite.

\section{GENESIS OF THE DEPOSITS}

The Shirley Basin deposits are young, simple in form and mineralogy, and apparently unaltered by weathering or by significant redistribution of uranium. In addition, they have an obvious spatial and genetic relation to large tongues of altered sandstone. This detailed study of the deposits and of the environment in which they were formed was therefore undertaken in the hope that it would yield data on ore genesis more easily interpreted than similar data from older and more complicated deposits. Most of these data have been presented earlier in this report; here, these data are used to set up a genetic model for the Shirley Basin uranium deposits.

Conditions favorable for solution, transportation, and deposition of uranium probably came into being in late Miocene or early Pliocene time when the Shirley Basin, as we know it today, was buried beneath as much as 1,800 feet of clastic and tuffaceous rocl:s ranging from Eocene to Miocene in age. During mid-Tertiary time, ground-water flow, particularly in formations as deeply buried as the Wind River, was probably very slow, and ingress 
of vadose water into the Wind River may have been limited by the thick sequence of flat-lying Tertiary rocks that overlay the area. There is ample geologic evidence, in areas surrounding the Shirley Basin (Denson, 1969), that late Miocene time was marked by uplift of the mountain ranges and renewed erosion of rocks in the uplifts and on the flanks. The low northerly dip of rocks of Tertiary age now exposed in the Shirley Basin is thought to have originated at this time, a seemingly minor event that may have produced the hydraulic gradient necessary for the flow of uranium-bearing ground water throughout the permeable beds of the Wind River Formation.

Soon after uplift, ground water that carried uranium and other elements is thought to have percolated downward through the overlying rocks and then to have moved laterally along the permeable beds of the Wind River Formation, somewhat as shown in figure 51A. Later, after erosion of the Tertiary rocks on the flanks of the uplift, the uranium-bearing ground water may have entered the Wind River Formation directly by a path similar to that shown in figure $51 B$. The oxygenated ground water would at first be out of equilibrium with the reduced environment through which it moved, but oxidation of the rock components, particularly pyrite, and fossil wood would quickly produce conditions approximating equilibrium in an oxidized zone at and slightly downstream from the area of groundwater ingress. This zone, at first very small, would gradually expand in the direction of ground-water flow, and an interface would be established between reducing conditions in the downdip part of the aquifer and oxidizing conditions in the updip part. More correctly, several interfaces would be established, the position of each determined by the combined effect of $\mathrm{Eh}$ and $\mathrm{pH}$ changes on the solubility of various elements. The interface most commonly discussed, and incorrectly referred to as the interface or the solution front, is one between oxidized and reduced forms of iron, or, pyrite and goethite in the Shirley Basin area. Easily distinguished iron, uranium, and selenium interfaces occur in the Shirley Basin; iron, uranium, selenium, and molybdenum interfaces occur in the Gas Hills. Deposition of an
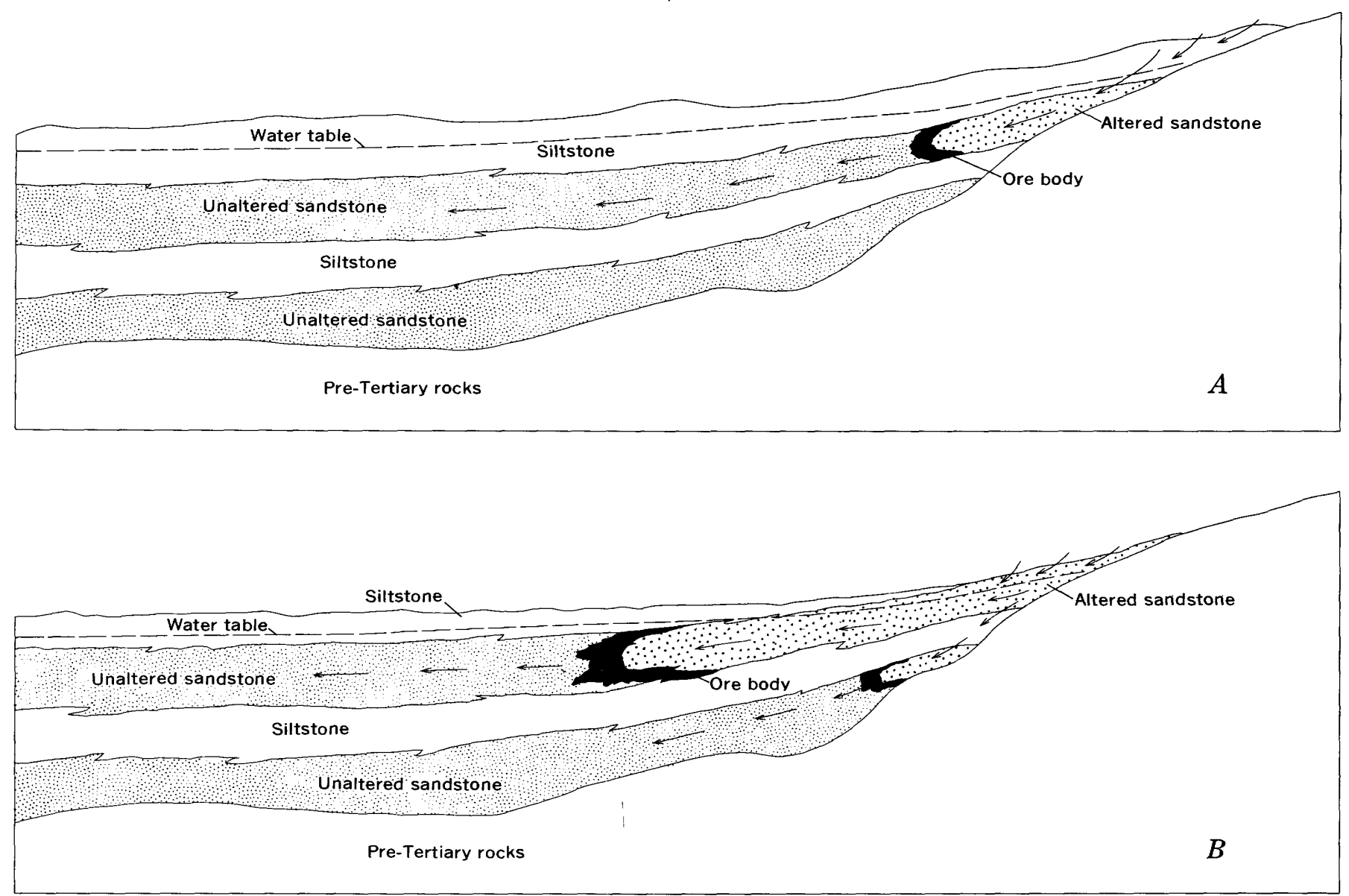

Figure 51. - Possible paths of circulation of ore-bearing solutions in the Shirley Basin area. Arrows indicate direction of ground-water flow. 
element carried by ground water appears to have occurred most rapidly at the redox interface for that element and less rapidly as the solution moved through the reducing zone. There was an overlap in the deposition of the several ore elements.

Changes in Eh have been considered by most geologists to be the principal cause of deposition in sandstone-type uranium deposits. However, the Eh$\mathrm{pH}$ diagrams of Garrels and Christ (1965), applicable to uranium deposits, and those of Hostetler and Garrels (1962) show that $\mathrm{pH}$ changes may be of equal importance in precipitation of some of the component minerals. The writer, in an earlier publication (Harshman, 1966), pointed out the genetic similarities between secondary sulfide deposits and uranium deposits in sandstone and postulated that oxidation of pyrite accompanying uranium ore would cause a sharp drop in $\mathrm{pH}$ near the redox interface for iron. Figure 52 is reproduced from that earlier publication to illustrate the postulated $\mathrm{Eh}$ and $\mathrm{pH}$ conditions in and near the Shirley Basin deposits.

Lisitsyn and Kuznetsova (1967) and Germanov and Panteleyev (1967) collected ground-water samples, from below the permanent water table, in traverses extending from altered sandstone, through ore and mineralized sandstone, and into unaltered sandstone. The first two investigators sampled a zone of "epigenetic mineralization" (uranium is not mentioned); the latter investigators sampled uranium deposits similar in most aspects to the roll-type deposits of the Shirley Basin. The Eh and $\mathrm{pH}$ values determined by these investigators for the zones in the Russian deposits are remarkably similar to those postulated for similar zones in the Shirley Basin.

Any mineralized zone established early in the cycle just described would be small and of low tenor. It would migrate in the direction of ground-water flow, generally downdip, by oxidation and solution on the updip side of the zone and reduction and redeposition on the downdip side. A continuous ex- ternal supply of uranium and associated elements in the ground water passing through the zone of deposition would cause the mineralized zone to grow in both size and grade and to eventually reach the magnitude of present-day ore bodies.

The genetic processes proposed for the Shirley Basin deposits and the multiple migration-accretion theory of Gruner (1956) have some broad similarities, but they have very basic differences. The first step in the multiple migration-accretion theory is the formation of a large body of mineralized sandstone of very low tenor. Repeated cycles of uplift, exposures, oxidation, migration, and deposition redistribute the uranium from the original mineralized-sandstone body into an increasingly higher grade deposit that finally reaches ore grade. This is a discontinuous process, and it does not require the addition of "new" uranium after the first large low-grade deposit forms. In marked contrast, the Shirley Basin ore bodies are thought to have started with very small low-grade deposits that grew in size and grade by redistribution of the uranium in them and the continuous addition of "new" uranium to them. Though oxidation and reduction are essential to the concept, the entire process takes place at depth, and repeated uplift and exposure play no part in it. The process would continue until the supply of uranium and associated elements was exhausted, the environment causing deposition was destroyed, or the hydrodynamic system was disrupted.

The shape of the altered-sandstone tongues, the shape and position of the ore bodies, and the distribution of the elements in and near ore suggest that the ore-bearing solutions in the Shirley Basin were moving northwestward at the time of ore deposition. Today the ground-water flow is southward at gradients of 10-30 feet per mile, and the divide that separates northerly from southerly flowing ground water lies 5 miles or more north of the ore deposits,

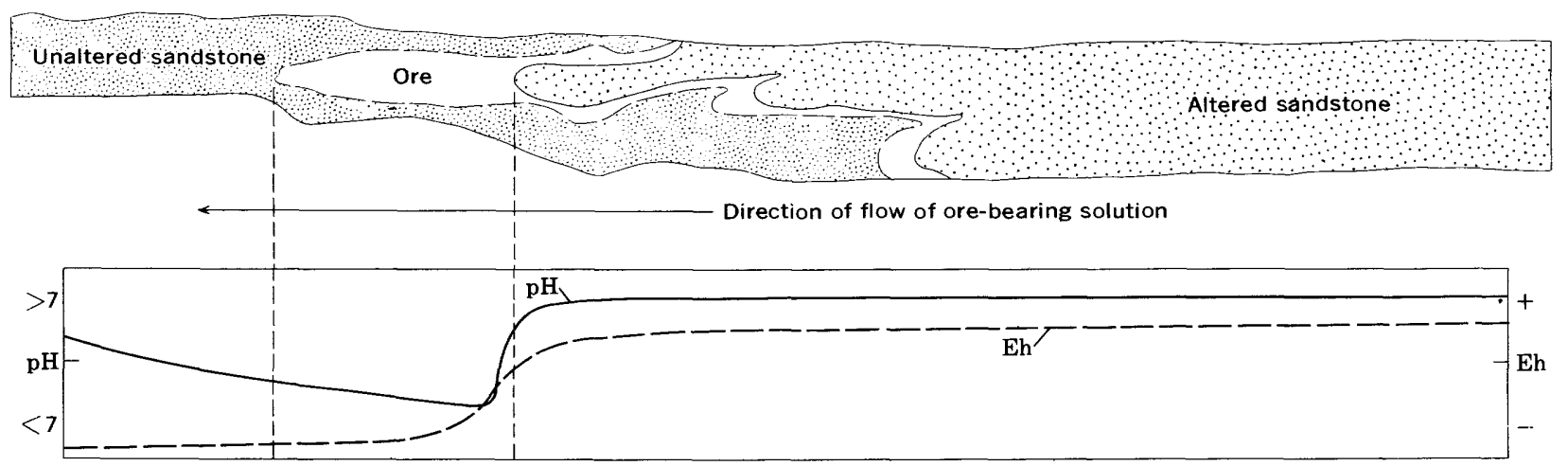

FIgURE 52. - Postulated $\mathrm{Eh}$ and $\mathrm{pH}$ conditions for a unit of solution during transportation and deposition of uranium and other elements, Shirley Basin. 
near the south-facing erosional scarp that marks the contact between the upper and lower members of the White River Formation shown on the geologic map (Harshman, 1968b). It is postulated that the ore deposits were formed by northwesterly flowing ground water when the ground-water divide was south of the altered-sandstone tongues, and that the ore-forming processes were disrupted when the divide migrated northward and the direction of ground-water flow reversed.

\section{AGE}

The Shirley Basin deposits are in rocks of early Eocene age, and thus they are less than 50 million years old; how much less is not known. Radioactivity disequilibrium studies by Dooley, Tatsumoto, and Rosholt (1964) indicate that the deposits are more than 250,000 years old. In an effort to narrow the gap between these two limits, total $\mathrm{Pb} / \mathrm{U}$ ratios of 15 ore samples that contained more than 2 percent uranium were determined and are plotted in figure 53. The average content of these samples

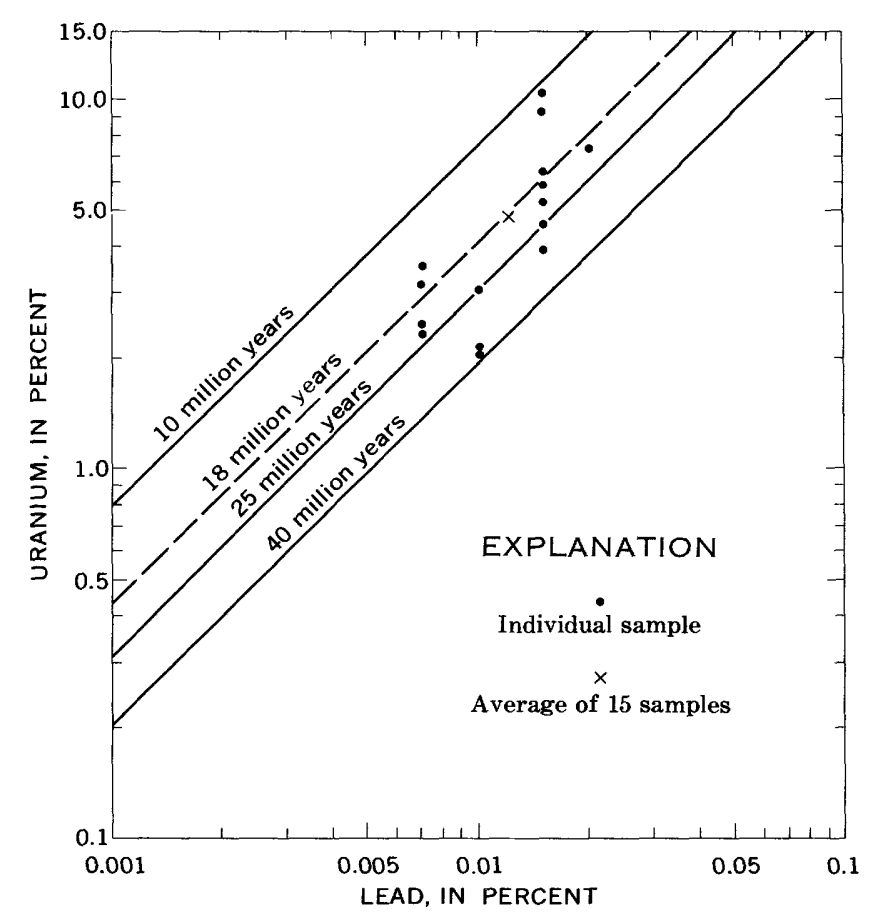

Figure 53. - Total $\mathrm{Pb} / \mathrm{U}$ ratios of 15 high-grade ore samples from the Shirley Basin. (Isochrons plotted from Stieff and others, 1959.)

is 4.83 percent uranium and 0.0122 percent lead, amounts that suggest an age of about 18 million years. Ages determined in this manner are subject to considerable error, but from the geologic viewpoint an age of about 18 million years is reasonable, for in late Miocene time there was uplift of the mountain ranges bounding the Shirley Basin, accompanied by vigorous renewed erosion. This uplift is thought to have been the event that spawned the hydrodynamic cycle responsible for the ore deposits.

\section{URANIUM DEPOSITS IN OTHER ROCKS}

Although the largest and economically most significant uranium deposits in the Shirley Basin are in sandstone, small deposits of ore-grade material are associated with jasper along the karst surface at the top of the Madison Limestone. Ore and accessory minerals are apatite, goethite, chalcedony, calcite, and quartz. They fill open spaces in a limestone breccia that characterizes the karst surface, and they replace some of the limestone fragments. The apatite is very fine grained or cryptocrystalline, and it is intergrown with fine-grained goethite. In some samples apatite intergrown with goethite is in rhomb-shaped aggregates, pseudomorphous after either calcite or dolomite rhombs.

A small pit excavated near the center of sec. 12 , T. 28 N., R. 77 W., exposes the mineralized karst surface to a depth of about 6 feet in an area of high surface radioactivity. A selected sample of the ore contained 0.26 percent $\mathrm{U}_{3} \mathrm{O}_{8}$ and had an equivalent uranium $(\mathrm{eU})$ of 0.22 percent $\mathrm{U}_{3} \mathrm{O}_{8}$. Autoradiographs of thin slabs of the ore show that the uranium is associated with the iron-bearing apatite, not with the chalcedony. A spectrographic analysis of the ore showed $\mathrm{Si}$ and $\mathrm{Ca}$ to be the major constituents and the contents of other elements, in percent, to be as follows: $\mathrm{P}, 5.0 ; \mathrm{Al}, 0.07 ; \mathrm{Fe}, 2.0 ; \mathrm{Mg}$, $0.05 ; \mathrm{Na}, 0.03 ; \mathrm{Mn}, 0.1 ; \mathrm{Ni}, 0.015 ; \mathrm{Ba}, 0.02 ; \mathrm{Pb}$, $0.02 ; \mathrm{Sr}, 0.05 ; \mathrm{V}, 0.015 ; \mathrm{Ti}, \mathrm{Co}, \mathrm{Cr}, \mathrm{Cu}, \mathrm{Mo}, \mathrm{Y}$, $\mathrm{Yb}, 0.0002-0.005$.

The karst surface is not everywhere mineralized or radioactive, and the deposits appear to be restricted to a part of the surface that was close to or in direct contact with the White River Formation that once overlay the entire area. The deposits are believed to have been formed by vadose waters that leached uranium and associated elements from the White River Formation. These solutions moved along the most permeable zones in the karst surface and deposited uranium-bearing apatite, chalcedony, and other associated minerals as fillings of open spaces or as replacements of carbonate minerals.

Anomalously high radioactivity has been noted near the base of the Wagon Bed Formation in the SE1/4 sec. 25 , T. 28 N., R. 78 W. Several cuts were bulldozed prior to 1959 to explore the anomaly, but nothing of economic interest seems to have been found. A selected sample of the most radioactive 
material in these pits contained 0.001 percent uranium.

\section{MONAZITE DEPOSITS IN TERTIARY ROCKS}

Several areas of high radioactivity in Tps. 27 and $28 \mathrm{~N}$., Rs. 79, 80, and $81 \mathrm{~W}$., were found as a result of airborne surveys made by geologists Page Jenkins and Darby Hand in the summer of 1953. The areas lie just south of the south rim of Bates Hole in a region of Tertiary rocks (shown on geologic investigations map I-539, Harshman, 1968b). The cause of the high radioactivity was first thought to be uranium but was subsequently shown to be monazite in the sandy and conglomeratic beds of the Wind River and White River Formations or in alluvium derived from these beds. Page Jenkins (written commun., 1953-54), who explored the areas in 1953 and 1954 and collected about 230 samples from shallow holes drilled on a rectangular pattern, furnished the following data on these monazite deposits.

The exploration program showed that minor amounts of monazite are present in the coarsegrained rocks over an area of about 40 square miles and that six areas contained considerably greater amounts. Estimates of the monazite content of samples were based on the weight of heavy minerals in each 5-pound sample of sand and on a determination that the composite of the heavy-mineral separates contained 52 percent monazite. Monazite contents ranged from a few hundredths of a pound to 1.43 pounds per ton of sand; most samples contained less than 1 pound per ton. The composite samples of concentrates contained about 34.5 percent rare-earth oxides and 1.61 percent $\mathrm{ThO}_{2}$. The monazite therefore contained about twice these amounts.

The coarse-grained facies of the Wind River and of the White River Formations in this western part of the Shirley Basin were derived from light-colored granites now exposed farther to the west in the Shirley and Granite Mountains. The monazite probably originated in these rocks of Precambrian age.

\section{CONSTRUCTION MATERIALS}

Materials for road and concrete structures are available in the Shirley Basin area. The Shirley Ridge road, which leads from State Highway 487 to the mining area, has been surfaced with silicified tuff obtained from pits along Moss Agate Ridge. This material requires no processing before being used on the road.
Sand and gravel can be obtained from the coarsegrained beds of the Wind River Formation at many points in the Shirley Basin. Concrete made from these materials seems to be of fair quality, although the high silica content of the gravels may cause some adverse reaction with high alkali cement.

\section{REFERENCES CITED}

Adler, H. H., 1964, The conceptual uranium ore roll and its signinicance in uranium exploration: Econ. Geology, v. 59 , no. 11 , p. $46-53$.

Agatston, R. S., 1954, Pennsylvanian and Lower Permian of northern and eastern Wyoming: Am. Assoc. Petroleum Geologists Bull., v. 38, no. 4, p. 508-583.

Bailey, R. V., 1965, Applied geology in the Shirley Basin uranium district, Wyoming: Wyoming Univ. Contr. Geology, v. 4, no. 1, p. 27-35.

Bartram, J. G., 1930, Triassic-Jurassic red beds of the Rocky Mountain region: Jour. Geology, v. 38, no. 4, p. 335-345.

Beath, O. A., 1943, Toxic vegetation growing on the Salt Wash member of the Morrison formation: Am. Jour. Botany, v. 30, no. 9, p. 698-707.

Beath, O. A., Hagner, A. F., and Gilbert, C. S., 1946, Some rocks and soils of high selenium content: Wyoming Geol. Survey Bull. 36, 23 p.

Beus, A. A., 1962, Beryllium - Evaluation of deposits during prospecting and exploratory work [translated from Russian]: San Francisco, W. H. Freeman and Co., 161 p.

Burk, C. A., and Thomas, H. D., 1956, The Goose Egg Formation (Permo-Triassic) of eastern Wyoming: Wyoming Geol. Survey Rept. Inv. 6, $11 \mathrm{p}$.

Cheney, E. S., and Jensen, M. L., 1966, Stable isotope geology of the Gas Hills, Wyoming, uranium district: Econ. Geology, v. 61, no. 1, p. 44-71.

Cobban, W. A., 1963, Occurrence of the Late Cretaceous ammonite Hoplitoplacenticeras in Wyoming, in Short papers in geology and hydrology: U.S. Geol. Survey Prof. Paper 475-C, p. C60-C62.

Darton, N. H., 1898, Preliminary report on the geology and water resources of Nebraska west of the one hundred and third meridian: U.S. Geol. Survey 19th Ann. Rept., pt. 4, p. 719-785.

1899, Jurassic formations of the Black Hills of South Dakota: Geol. Soc. America Bull., v. 10, p. 383-396; abs. in Am. Geologist, v. 23, p. 94 (1899) ; Science, new ser., v. 9, p. 103 (1899).

1904, Comparison of the stratigraphy of the Black Hills, Bighorn Mountains, and Rocky Mountain front range: Geol. Soc. America Bull., v. 15, p. 379-448; abs. in Science, new ser., v. 17, p. 292 (1903).

1908, Paleozoic and Mesozoic of central Wyoming: Geol. Soc. America Bull., v. 19, p. 403-470.

Darton, N. H., Blackwelder, Eliot, and Siebenthal, C. E., 1910, Description of the Laramie and Sherman quadrangles [Wyoming]: U.S. Geol. Survey Geol. Atlas, Folio $173,17 \mathrm{p}$.

Darton, N. H., and Siebenthal, C. E., 1909, Geology and mineral resources of the Laramie Basin, Wyoming: U.S. Geol. Survey Bull. 364, 81 p. 
Denson, N. M., 1965, Miocene and Pliocene rocks of central Wyoming, in Cohee, G. V., and West, W. S., Changes in stratigraphic nomenclature by the U.S. Geological Survey, 1964: U.S. Geol. Survey Bull. 1224-A, p. A70-A74. 1969, Distribution of nonopaque heavy minerals in Miocene and Pliocene rocks of central Wyoming and parts of adjacent States, in Geological Survey research 1969: U.S. Geol. Survey Prof. Paper 650-C, p. C25-C32.

Denson, N. M., Bachman, G. O., and Zeller, H. D., 1951, Summary of new information on uraniferous lignites in the Dakotas: U.S. Geol. Survey Rept. (to the U.S. Atomic Energy Comm.) TEM-175, 10 p.

Denson, N. M., and Harshman, E. N., 1969, Map showing areal distribution of Tertiary rocks, Bates Hole-Shirley basin area, south-central Wyoming: U.S. Geol. Survey Misc. Geol. Inv. Map I-570.

Dooley, J. R., Jr., Tatsumoto, Mitsunobu, and Rosholt, J. N., 1964, Radioactive disequilibrium studies of roll features, Shirley Basin, Wyoming: Econ. Geology, v. 59, no. 4, p. 586-595.

Emmons, S. F., Cross, Whitman, and Eldridge, G. H., 1896, Geology of the Denver Basin in Colorado: U.S. Geol. Survey Mon. 27, 556 p.

Fischer, R. P., 1942, Vanadium deposits of Colorado and Utah, a preliminary report: U.S. Geol. Survey Bull. 936-P, p. 363-394 [1943].

Garrels, R. M., and Christ, C. L., 1965, Solutions, minerals, and equilibria: New York, Harper and Row, $450 \mathrm{p}$.

Germanov, A. I., and Panteleyev, V. M., 1967, Behavior of organic matter in ground water during infiltrational epigenesis: Akad. Nauk SSSR Izv. Ser. Geol., no. 12, p. 113-120; English translation, Internat. Geology Rev., v. 10 , no. 7 , p. 826-832 (1968).

Gill, J. R., 1962, Tertiary landslides, northwestern South Dakota and southeastern Montana: Geol. Soc. America Bull., v. 73 , no. 6 , p. 725-735.

Goleva, G. A., and Lushnikov, V. V., 1967, Selenium distribution in underground waters of ore deposits and some types of mineral waters: Geokhimiya, no. 4, p. 438-445; English translation, Geochemistry Internat., v. 4, no. 2, p. 378-385 (1967).

Govorov, I. N., and Stunzhas, A. A., 1963, Mode of transport of beryllium in alkali metasomatism [English translation]: Geochemistry, no. 4, p. 402-409.

Granger, H. C., 1963, Mineralogy, in Geology and technology of the Grants uranium region: New Mexico Bur. Mines and Mineral Resources Mem. 15, p. 21-37.

1966, Ferroselite in a roll-type uranium deposit, Powder River basin, Wyoming, in Geological Survey research 1966: U.S. Geol. Survey Prof. Paper 550-C, p. C133-C137.

Granger, H. C., Santos, E. S., Dean, B. G., and Moore, F. B., 1961, Sandstone-type uranium deposits at Ambrosia Lake, New Mexico - An interim report: Econ. Geology, v. 56, no. 7, p. 1179-1210.

Granger, H. C., and Warren, C. G., 1969, Unstable sulfur compounds and the origin of roll-type uranium deposits: Econ. Geology, v. 64, no. 2, p. 160-171.

Gruner, J. W., 1956, Concentration of uranium in sediments by multiple migration-accretion: Econ. Geology, v. 51, no. 6 , p. $495-520$.
Grutt, E. W., Jr., 1957, Environment of some Wyoming uranium deposits, in Advances in nuclear engineering: $\mathrm{Nu}-$ clear Eng. and Sci. Cong., 2d, Philadelphia, Proc. 2d Conf., v. 2, p. 313-323.

Harshman, E. N., 1961, Paleotopographic control of a uranium mineral belt, Shirley Basin, Wyoming, in Short papers in the geologic and hydrologic sciences: U.S. Geol. Survey Prof. Paper 424-C, p. C4-C6.

1962, Alteration as a guide to uranium ore, Shirley Basin, Wyoming, in Short papers in geology, hydrology, and topography: U.S. Geol. Survey Prof. Paper 450-D, p. D8-D10.

1966, Genetic implications of some elements associated with uranium deposits, Shirley Basin, Wyoming, in Geological Survey research 1966: U.S. Geol. Survey Prof. Paper 550-C, p. C167-C173.

1968a, Uranium deposits of the Shirley Basin, Wyoming, in Ridge, J. D., ed., Ore deposits of the United States, 1933-1967 (Graton-Sales volume): New York, Am. Inst. Mining, Metall., and Petroleum Engineers, v. 1, p. 849-856.

$1968 \mathrm{~b}$, Geologic map of the Shirley basin area, Albany, Carbon, Converse, and Natrona Counties, Wyoming: U.S. Geol. Survey Misc. Geol. Inv. Map I-539.

Hay, R. L., 1963, Stratigraphy and zeolitic diagenesis of the John Day Formation of Oregon: California Univ. Pubs. Gèol. Sei., v. 42, no. 5, p. 199-262.

Hemley, J. J., and Jones, W. R., 1964, Chemical aspects of hydrothermal alteration with emphasis on hydrogen metasomatism: Econ. Geology, v. 59, no. 4, p. 538-567.

High, L. R., Jr., and Picard, M. D., 1967, Rock units and revised nomenclature, Chugwater Group (Triassic), western Wyoming: Mtn. Geologist, v. 4, no. 2, p. 73-81.

Hintze, F. F., Jr., 1915, The Basin and Greybull oil and gas fields: Wyoming Geologist's Office Bull. 10, $62 \mathrm{p}$.

Hostetler, P. B., and Garrels, R. M., 1962, Transportation and precipitation of uranium and vanadium at low temperatures, with special reference to sandstone-type uranium deposits: Econ. Geology, v. 57, no. 2, p. 137-167.

Imlay, R. W., 1947, Marine Jurassic of Black Hills area, South Dakota and Wyoming: Am. Assoc. Petroleum Geologists Bull., v. 31, no. 2, p. 227-273.

Jensen, M. L., 1958, Sulfur isotopes and the origin of sandstone-type uranium deposits [Colorado Plateau and Wyo.]: Econ. Geology, v. 53, no. 5, p. 598-616.

Kashirtseva, M. F., 1964, Mineralic and chemical zonality in uranium infiltration ore occurrences: Sovetskaya Geologiya, no. 10, p. 51-65.

Keefer, W. R., and Van Lieu, J. A., 1966, Paleozoic formations in the Wind River Basin, Wyoming: U.S. Geol. Survey Prof. Paper 495-B, 60 p.

King, J. W., and Austin, S. R., 1966, Some characteristics of roll-type uranium deposits at Gas Hills, Wyoming: Mining Eng., v. 18, no. 5, p. 73-80.

Knight, S. H., 1917, Age and origin of the red beds of southeastern Wyoming [abs., with discussion by Erasmus Haworth and E. B. Branson]: Geol. Soc. America Bull., v. 28 , no. 1 , p. $168-169$.

1929, The Fountain and the Casper formations of the Laramie Basin; a study on genesis of sediments: Wyoming Univ. Pub. Sci. Geology, v. 1, no. 1, p. 1-82.

Knight, W. C., 1902, The petroleum fields of Wyoming: Eng. and Mining Jour., v. 73, p. 720-723. 
Koeberlin, F. R., 1938, Sedimentary copper, vanadium-uranium, and silver in southwestern United States: Econ. Geology, v. 33 , no. 4 , p. 458-461.

Konkel, Phillip, 1935, The geology of the northeast portion of the Laramie Basin, Little Medicine district, Wyoming: Wyoming Univ. unpub. M.A. thesis, 59 p., map.

Lakin, H. W., 1961, Geochemistry of selenium in relation to agriculture, in Selenium in agriculture: U.S. Dept. Agriculture Handb. 200, p. 3-12.

Lee, W. T., 1927, Correlation of geologic formations between east-central Colorado, central Wyoming, and southern Montana: U.S. Geol. Survey Prof. Paper 149, 80 p.

Lindgren, Waldemar, Graton, L. C., and Gordon, C. H., 1910, The ore deposits of New Mexico: U.S. Geol. Survey Prof. Paper 68, $361 \mathrm{p}$.

Lipman, P. W., 1965, Chemical comparison of glassy and crystalline volcanic rocks: U.S. Geol. Survey Bull. 1201-D, $24 \mathrm{p}$.

Lisitsyn, A. K., and Kuznetsova, E. C., 1967, Role of microorganisms in development of geochemical reduction barriers where limonitization bedded zones wedge-out: Akad. Nauk SSSR Izv. Ser. Geol., no. 1, p. 31-44; English translation, Internat. Geology Rev., v. 9, no. 9, p. 11801191 (1967).

Love, J. D., 1939, Geology along the southern margin of the Absaroka Range, Wyoming: Geol. Soc. America Spec. Paper 20, $134 \mathrm{p}$.

1952, Preliminary report on uranium deposits in the Pumpkin Buttes area, Powder River Basin, Wyoming: U.S. Geol. Survey Circ. 176, 37 p.

Love, J. D., Denson, N. M., and Botinelly, Theodore, 1949, Geology of the Glendo area, Wyoming: U.S. Geol. Survey Oil and Gas Inv. Prelim. Map 92, 2 sheets.

Love, J. D., Weitz, J. L., and Hose, R. K., 1955, Geologic map of Wyoming: U.S. Geol. Survey.

Lupton, C. T., 1916, Oil and gas near Basin, Big Horn County, Wyoming: U.S. Geol. Survey Bull. 621-L, p. 157-190.

Maughan, E. K., 1963, Mississippian rocks in the Laramie Range, Wyoming, and adjacent areas, in Short papers in geology and hydrology: U.S. Geol. Survey Prof. Paper 475-C, p. C23-C27.

1964, The Goose Egg Formation in the Laramie Range and adjacent parts of southeastern Wyoming, in Geological Survey research 1964: U.S. Geol. Survey Prof. Paper 501-B, p. B53-B60.

Maughan, E. K., and Wilson, R. F., 1960, Pennsylvanian and Permian strata in southern Wyoming and northern Colorado, in Weimer, R. J., and Haun, J. D., eds., Rocky Mtn. Assoc. Geologists Guide to the geology of Colorado: Denver, Colo., p. 34-42.

Meek, F. B., and Hayden, F. V., 1858, Descriptions of new species and genera of fossils, collected by Dr. F. V. Hayden in Nebraska Territory, under the direction of Lieut. G. K. Warren, U.S. Topographical Engineer; with some remarks on the Tertiary and Cretaceous formations of the north-west, and the parallelism of the latter with those of other portions of the United States and Territories: Acad. Nat. Sci. Philadelphia Proc., 1857, v. 9, p. 117-148.
1862, Descriptions of new Lower Silurian (Primordial), Jurassic, Cretaceous, and Tertiary fossils, collected in Nebraska Territory by the Exploring Expedition under the command of Capt. Wm. F. Raynolds, U.S. Topographical Engineer, with some remarks on the rocks from which they were obtained: Acad. Nat. Sci. Philadelphia Proc., 1861, v. 13, p. 415-447.

Melin, R. E., 1964, Description and origin of uranium deposits in Shirley Basin, Wyoming: Econ. Geology, v. 59, no. 5, p. 835-849.

Miller, A. K., and Thomas, H. D., 1936, The Casper formation (Pennsylvanian) of Wyoming and its cephalopod fauna: Jour. Paleontology, v. 10, no. 8, p. 715-738.

Mrak, V. A., 1968, Uranium deposits in the Eocene sandstones of the Powder River basin, Wyoming, in Ridge, J. D., ed., Ore deposits of the United States, 1933-1967 (Graton-Sales volume) : New York, Am. Inst. Mining, Metall., and Petroleum Engineers, v. 1, p. 338-848.

Peale, A. C., 1893, The Paleozoic section in the vicinity of Three Forks, Montana, with petrographic notes by G. P. Merrill: U.S. Geol. Survey Bull. 110, 56 p.

Peterson, A. F., 1935, Geology of the Shirley Basin and Bates Hole region, Carbon County and Natrona County, Wyoming: Wyoming Univ. unpub. M.A. thesis, 70 p., map.

Pettijohn, F. J., 1957, Sedimentary rocks [2d ed.] : New York, Harper \& Bros., 718 p.

Pipiringos, G. N., 1948, Marine Jurassic and related rocks of Laramie Basin, Wyoming [abs.]: Geol. Soc. America Bull., v. 59, no. 12 , pt. 2, p. 1399-1400.

1957, Stratigraphy of the Sundance, Nugget and Jelm formations in the Laramie Basin, Wyoming: Wyoming Geol. Survey Bull. 47, 63 p.

1968, Correlation and nomenclature of some Triassic and Jurassic rocks in south-central Wyoming: U.S. Geol. Survey Prof. Paper 594-D, 26 p.

Rackley, R. I., Shockey, P. N., and Dahill, M. P., 1968, Concepts and methods of uranium exploration, in Black Hills area, South Dakota, Montana, Wyoming-Wyoming Geol. Assoc. Guidebook, 20th Field Conf., 1968: Casper, Wyo., Petroleum Inf., p. 115-124.

Rich, E. I., 1962, Reconnaissance geology of Hiland-Clarkson Hill area, Natrona County, Wyoming: U.S. Geol. Survey Bull. 1107-G, p. 447-540.

Riedl, Gary, 1959, Geology of the eastern portion of Shirley Basin, Albany and Carbon Counties, Wyoming: Wyoming Univ. unpub. M.S. thesis, 49 p., map.

Roehler, H. W., 1958, Geology of Bates Hole, Wyoming: Wyoming Univ. unpub. M.S. thesis, 58 p., map.

Rosholt, J. N., Harshman, E. N., Shields, W. R., and Garner, E. L., 1964, Isotopic fractionation of uranium related to roll features in sandstone, Shirley Basin, Wyoming: Econ. Geology, v. 59, no. 4, p. 570-585.

St. John, O. H., 1883, Report on the geology of the Wind River district: U.S. Geol. and Geog. Survey Terr. (Hayden) 12th Ann. Rept., pt. 1, p. 173-269.

Sato, Yoshiaki, and Denson, N. M., 1967, Volcanism and tectonism as reflected by the distribution of nonopaque heavy minerals in some Tertiary rocks of Wyoming and adjacent States, in Geological Survey research 1967: U.S. Geol. Survey Prof. Paper 575-C, p. C42-C54. 
Schlaikjer, E. M., 1935, A new basal Oligocene formation, pt. 3 of Contributions to the stratigraphy and palaeontology of the Goshen Hole area, Wyoming: Harvard Coll. Mus. Comp. Zoology Bull., v. 76, p. 69-94.

Schultz, C. B., and Stout, T. M., 1955, Classification of Oligocene sediments in Nebraska - A guide for the stratigraphic collecting of fossil mammals: Nebraska Univ. State Mus. Bull., v. 4, no. 2, p. 17-52.

Shawe, D. R., 1956, Significance of roll ore bodies in genesis of uranium-vanadium deposits on the Colorado Plateau, in Page, L. R., Stocking, H. E., and Smith, H. B., compilers, Contributions to the geology of uranium and thorium by the United States Geological Survey and Atomic Energy Commission for the United Nations International Conference on Peaceful Uses of Atomic Energy, Geneva, Switzerland, 1955: U.S. Geol. Survey Prof. Paper 300, p. 239-241; also in United Nations, 1956, Geology of uranium and thorium, v. 6, p. 335-337.

Shipp, B. G., 1959, Geology of an area east of Bates Hole, Carbon County and Albany County, Wyoming: Wyoming Univ. unpub. M.S. thesis, 69 p., map.

Sinclair, W. J., and Granger, Walter, 1911, Eocene and Oligocene of the Wind River and Bighorn basins [Wyo.]: Am. Mus. Nat. History Bull., v. 30, p. 83-117.

Stieff, L. R., Stern, T. W., Oshiro, Seiki, and Senftle, F. E., 1959, Tables for the calculation of lead isotope ages: U.S. Geol. Survey Prof. Paper 334-A, p. 1-40.
Thomas, H. D., 1948, Summary of Paleozoic stratigraphy of the Wind River Basin, Wyoming, in Wyoming Geol. Assoc. Guidebook, 3d Ann. Field Conf., Wind River Basin, 1948: p. 79-95.

Thompson, M. L., and Thomas, H. D., 1953, Systematic paleontology of fusulinids from the Casper formation, pt. 2 of Fusulinids of the Casper formation of Wyoming: Wyoming Geol. Survey Bull 46, p. 15-56.

Van Houten, F. B., 1954, Geology of the Long Creek-Beaver Divide area, Fremont County, Wyoming: U.S. Geol. Survey Oil and Gas Inv. Map OM-140, 2 sheets.

1964, Tertiary geology of the Beaver Rim area, Fremont and Natrona Counties, Wyoming: U.S. Geol. Survey Bull. 1164, 99 p. [1965].

Warren, C. G., 1968, The synthesis of ferroselite from an aqueous solution at low temperature: Econ. Geology, v. 63 , no. 4 , p. $418-419$.

Weitz, J. L., and Love, J. D., 1952, Geologic map of Carbon County, Wyoming: U.S. Geol. Survey.

Weitz, J. L., Love, J. D., and Harbison, S. A., 1954, Geologic map of Natrona County, Wyoming: Wyoming Geol. Survey.

Wood, H. E. 2d, chm., and others, 1941, Nomenclature and correlation of the North American continental Tertiary: Geol. Soc. America Bull., v. 52, no. 1, p. 1-48. 


\section{INDEX}

[Italic page numbers indicate major references]
A

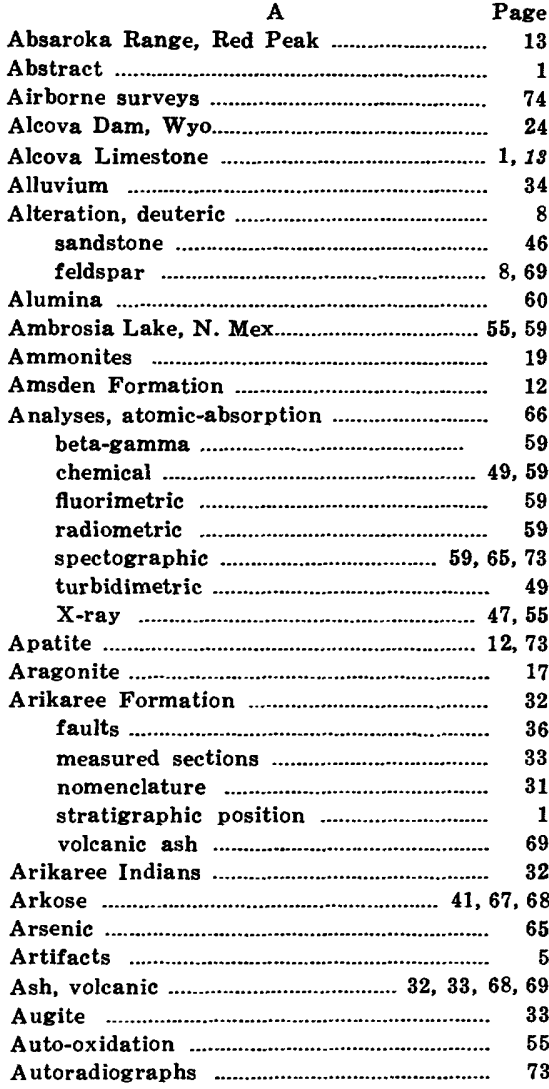

B

Bailey, R. V., fossil collection......................... 24 Barium ...................................................... 66 Bates Creek .............................................. 1, 3,

Bates Hole ............................................ 1, 2,

airborne survey ...................................... 74

Arikaree Formation ................................ 32

Cretaceous shales ...................................... 3

faults .................................................. 36

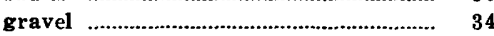

landslides .............................................. 35

measured sections ................................ 28, 30

Tertiary rocks ............................................

White River Formation ......................... 26

Wind River Formation ............................. 20

Beaver Divide, Wyo................................. 24, 25, 33

Belemnites ..................................................... 15

Benton Formation .......................................... 17

Bentonite ................................................... 17

Beryllium ….......................................... 2, 65, 69

Bicarbonate .............................................. 1, 39

Bighorn Basin ........................................... 16

Bighorn Mountains ....................................... 17

Biotite ............................................. 8, 18, 57

Black Hills, S. Dak ........................................... 14

Black ore ..........................................................

Breccia zones
Mesozoic outcrops ............................... 7, 19

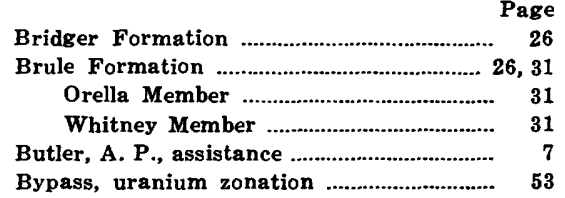

$\mathbf{C}$

Calcite, accessory ore mineral .............. 2, 41, 73 concretions ...............................56,60,63 epigenetic mineral ..................................... 53 in depositional sequence ........................ 58

in uranium deposits ............................... 56 ore cementation ................................... 54, 63 vugs ................................................... 11

Calcium ….......................................... 39, 66,68

Calcium carbonate ................... 17, 18, 33, 48, 68 Canyon Springs Sandstone Member, Sundance Formation ................ 15

Carbon, analyses ........................................... $\quad 59$ in uranium deposits ............................... 63 mineral ....................................... 48, 59, 63

organic ................. 49, 59, 63

relation to solutions ................................69, 69

replacement by pyrite ........................... 53

systematic distribution ............................. 2

Wind River Formation ....................... $\quad 48$

Carbonate .................................................69, 70

Carbonate minerals .................................. 73

Casper Formation ........................................ 12 nomenclature ................................................ 9 stratigraphic position ........................ 1, 11, 27

Casper, Wyo ............................................... 2, 6

Centennial Development Co............................ 7

Chadron Formation ..................................... 26

Chadronian provincial age ............................ 32

Chalcedony ….............................................. 73

Chalk Mountain .............................. 1, 3, 28, 32, 36 measured sections $25,30,33$

Chemistry, ground water ......................... 41, 69

Chert, Madison Limestone .......................... 11, 12

White River Formation ......................... 26

Chlorine ............................................... 41, 69

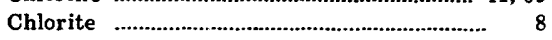

Chugwater Formation ................................. 13

Chugwater Group ......................................... 13

Clarkson Hill, Wyo.............................. 29, 31, 33

Clay ......................................... 18, 48, 53, 68 kaolin ............................................... 8,41

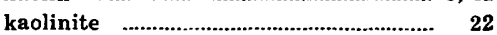
montmorillonite ................................. 22, 47, 60 sericite ................................................. 8

Claystone ..................................................... 44

Cloverly Formation ............................ 16

Jelm Formation ................................... 14

slide surface ............................................. 35

Wagon Bed Formation ......................... 24

White River Formation ......................... 26

Wind River Formation ........................... 21

Climate ....................................... 5, 23, 24, 35

Cloverly Formation ..................................... 16 slide blocks ............................................ 35 stratigraphic position ........................... 1 tipi rings ................................................ 5

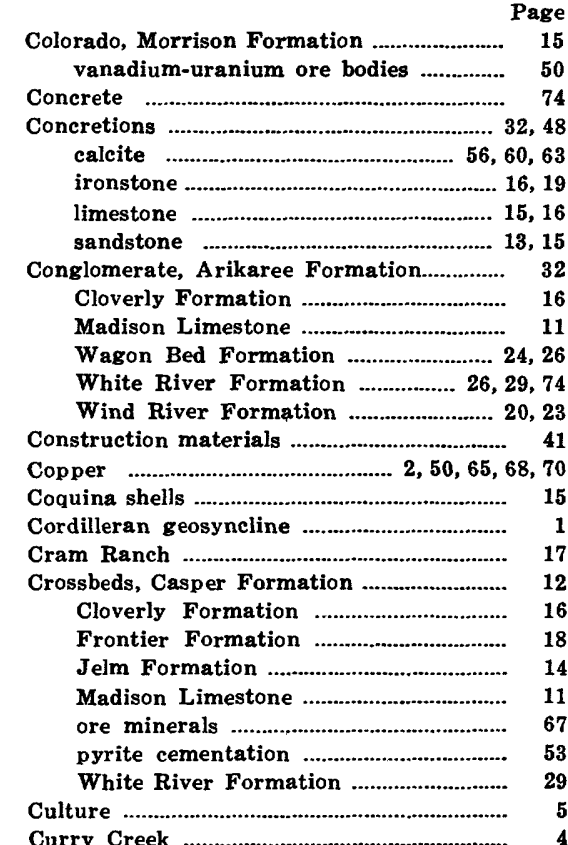

D

Deer Creek .................................................... 4 Denson, N. M., reconnaissance mapping.... 31 rock and heavy-mineral studies .......... 24, 25 Deposition of ore. See Uranium, deposition.

Diabase ................................................. 23, 26, 30

dikes ............................................. 4, 8, 36

Difficulty Shale Member, Goose Egg Formation ................................... 13

Dikes, diabase .......................................... 4, 8, 36 mafic ..................................................... 1 sandstone .................................................. 29

Dissolved solids, ground water ...................... 41

Dolomite, Casper Formation ............................ 12

Madison Limestone ................................... 11

Drainage, present ....................................... 1, 2,

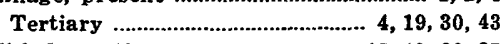

Drill-hole cuttings .......................... 18, 19, 20, 27

Dry Creek

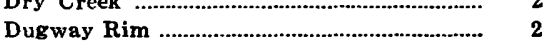

\section{E}

Economy ........................................................ Elements, distribution ............................. 2, 58, 72 See also names of specific elements.

Elk Creek .............................................. 34

Environment of deposition .............................. 44

Epidote .......................................................... 8,47

Equivalent uranium .................................... 59

Ervay Member, Goose Egg Formation........ 13

F

Faults ........................................... 1, 7, 15, 35

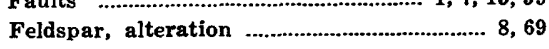

Precambrian ...................................... 8, 20

5

4




$\begin{array}{llll}\text { Feldspar - Continued } & & \text { Pag } \\ \text { arkose } \\ \text { calcite replacement } \\ \text { hydrolysis }\end{array}$

Folds ……...................................... 1, 7, 19, 36

Forelle Limestone Member, Goose Egg

Formation ………............... 13

Fort Steele, Wyo......................................... 19

Fort Union Formation ..................................... 1, 19

Fort Union Group ....................................... 19

Fossils, Agriochoerus ....................................... 31

ammonites …….......................................... 19

Arikaree Formation .................................. 33

belemnites ............................................ 23,31

camel bone fragments .............................. 31

coquina shells .......................................... 15

Coryphodon sp ......................................... 23

crocodile scutes ………………………....... 23

fish scales .............................................. 17

garpike scales ........................................... 23

Hesperocyon gregarius .......................... 31

Hesperocyon paterculus .......................... 31

Hoplitoplacenticeras .................................. 19

Hyrachyus sp …………………-............. 23

Hyracodon nebrascensis .......................... 31

Hyracotherium sp ..................................... 23

leaves .................................................. $\quad 24$

Leptomeryx evansi ……………………....... 31

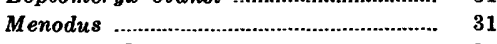

Metamynodon sp .................................... 31

Notharctus tenebrosus ........................... 25

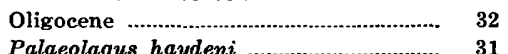

Palaeolagus haydeni ……...................... 31

$\begin{array}{lll}\text { Petrotomics Co. sec. 9 pit ......................... } & 23 \\ \text { Phenacodus primaevus ........................ } & 23\end{array}$

Poebrotherium sp ………………................ 31

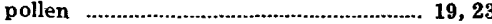

primate ................................................... 25

rhinocerous bone fragments ................. 31

root tubes ………................................ 17

Steele Shale …………................................. 19

Stylemys sp .......................................... 31

Subhyracodon occidentalis ................... 31

trails ...................................................... 15

Utah Construetion and Mining Co. open-pit mines

White River Formation …….................. 27, 31

Wind River Formation ......................... 23

wood …............................................. 71

Fractures, tension ...

Freezeout Shale Member, Goose Egg Formation

Frontier Formation

natural gas

paleotopography

stratigraphic position

underlying landslides ............................... 35

Wall Creek Sandstone Member .... 18, 42, 70

Frontier, Wyo............................................ 18

\section{G}

Gabbro

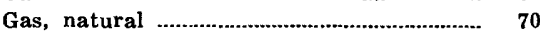

Gas Hills, altered sandstone ........................ 41, 67

interfaces ………………………............

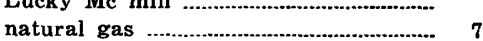

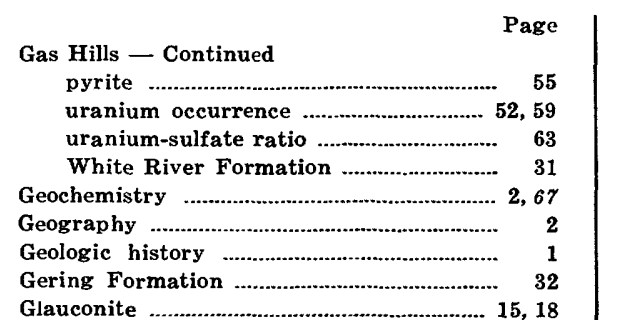

Glendo Shale Member, Goose Egg

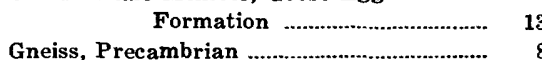

Goethite, accessory to uranium ore ............ 73 altered sandstone .................................. 2, 69 association with iron ............................... 60 association with selenium .................... 50, 62 interface ................................................

Goose Egg Formation ..................................... 13, 26 faults

nomenclature ………………………........... 9 stratigraphic position …………………..... 1

Gouge zones ……..................................... 36 Granite ……................................. 2, 30, 67, 74 Granite, batholith ….................................... 1 boulders …….................................. 20 Laramie Mountains ...................... 4, 8, 30, 67 Precambrian, Arikaree Formation ...... 33 composition ….................................. 8

Laramie Mountains ........................ 4, 8 source of monazites ........................... 74 stratigraphic position ....................... 27 White River Formation ................ 27, 29 Wind River Formation ................... 20 Granite Mountains ................... 19, 21, 30, 33, 74

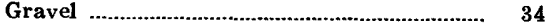

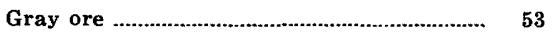
Great Lignite Group ……………………...... $\quad 19$

Ground water ............................................... 1 chemistry ……….................................... 41, 69 dissolved solids ......................................... $\quad 41$ hardness ............................................ 39 ore-bearing solutions ……...................... 59, 69

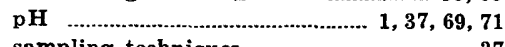
sampling techniques ................................ 37 temperature ……................................... 37 Tertiary flow ........................................... 70 Wind and White River Formations ..... 38, 41 Gypsum

\section{H}

Hand, Darby, airborne survey .................... 74

Hardness, ground water ............................... $\quad 39$

Hasler, J. W., assistance ....................................... 7

Hematite _...

accessory ore mineral .............................. 2, 41

calcite concentrations ............................... 56

epigenetic mineral ....................................... 53

Frontier Formation ............................. 18

in depositional sequence ............................ 58

Precambrian granite ………………....... 8

Hodges, Jay, assistance ............................... 7

Hogbacks ........................................... 14, 16, 35

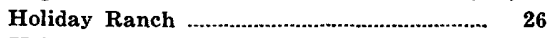

Holocene alluvium ………………………........ $\quad 34$

Homestake Mining Co...................................... 7

Hornblende ................................... 8, 33, 47, 57

Hulett Sandstone Member, Sundance Formation …………................ 15

Hydrogen sulfide ............................................ 2, 70

Hydrology ………………………………….... 37

Hydrothermal activity ..................................... $\quad 67$

\section{I}

Igneous activity 67
7,67

Igneous rocks

Indians
7,67

$5,32,35$
Page

Intermediate section .............................................. 53

Iron …………............................................ 60

analyses ….................... 59

color of alteration ..................................... 46

effect on depleted ore elements ............ 66

$\mathrm{Fe}^{+2} / \mathrm{Fe}^{+3}$ ratio ................................... 49, 69 reducing environment .............................. 70 systematic distribution ............................. 2

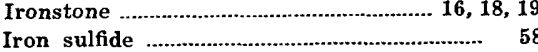

\section{J, $\mathbf{K}$}

Jasper, Casper Formation .............................. 12

Madison Limestone …………………..... 73 Jelm Formation ......................................... 1, 14, 35 Jelm Mountain …………................................... 14 Jenkins, Page, airborne survey ................. 74 Joints _............................................ 8,

Kaolin 8,41 Kaolinite Kerr McGee Corp ………................................ 1,

$\mathbf{L}$

Lak Member, Sundance Formation ….... 15 Lake beds ......................................... 25, 27, 32 Landslides _..._................................................ 35 Laramide orogeny ……………....................... 1 Laramie Mountains ..................................... 1, 2, Arikaree Formation ................................. 32 drainage ……………………………........ 19 granitic rocks …………………………....... 67 Paleozoic rocks .................................. 4 Precambrian core ....................................... 8 terrace gravel .............................................. 34

White River Formation .........................26, 30

Laughon, Robert B., assistance .................. 7

Lawn Creek ……….................................... 21

Leaching …………......................... 2,59,67,73 copper ………........................................ 65 in situ .............................................. 4

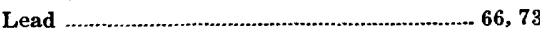

Leaves, fossil ................................................ 24

Leopold, Estella, fossil identification ........ 24 Lewis, G. Edward, fossil identification .. 25, 31

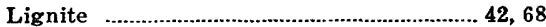
Thermopolis Shale ……………………... 17 Wind River Formation .............................. 23

Limestone, Alcova Limestone ...................... 13 Arikaree Formation ................................... 32 Casper Formation ……........................... 12 concretions …….................................... 15, 16 cuestas _..................................... 25 Goose Egg Formation ................................ 13 Madison Limestone .................................. 11, 41 Sundance Formation ............................... 14 Wagon Bed Formation ............................. 24 White River Formation ............................ 26

Limonite, association with iron ................. 60 association with selenium .................... 50,62 in altered sandstone ............................... 2, 69

Little Medicine Bow River, altitude ........ area of drainage ..................................... 2

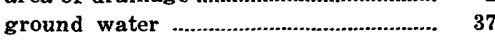
Niobrara Formation ................................. 18 terrace gravel ........................................ 34 Wind River-White River contact ....... 27 Little Medicine Member, Goose Egg Formation ............ 13

Location, Shirley Basin ………..................... 2 Logs. See Well logs.

Lost Cabin Member,

Wucky Mc mill

Lysite Member, Wind River Formation 19

\section{.}

.

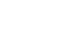




\begin{tabular}{|c|c|}
\hline $\mathbf{M}$ & \\
\hline Madison Limestone .................................... & \\
\hline $\begin{array}{l}\text { artifacts } \\
\text { karst topography }\end{array}$ & \\
\hline jasper ……ㄴ.. & 73 \\
\hline uranium ....... & \\
\hline nomenclature ............ & \\
\hline stratigraphic position .... & 1,27 \\
\hline 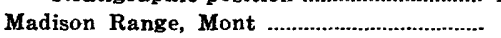 & 11 \\
\hline Magnesium ………........... & 41 \\
\hline Magnetite $-\cdots-1-1-1-1$ & \\
\hline Manganese ....……… & 63 \\
\hline Marcasite & 55 \\
\hline accessory ore mineral & \\
\hline altered sandstone & 48 \\
\hline association with hematite …………......... & 57 \\
\hline association with iron ............. & 60 \\
\hline 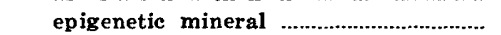 & 53 \\
\hline in depositional sequence & 58 \\
\hline 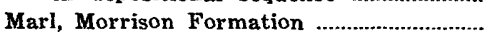 & 15 \\
\hline Measured sections, Arikaree Formation .... & 33 \\
\hline Bates Hole & \\
\hline Chalk Mountain & \\
\hline Petrotomics Co. sec. 9 pit .... & 21 \\
\hline Petrotomics Co. sec. 15 pit & 22 \\
\hline Wagon Bed Formation ………............ 2 & \\
\hline White River Formation ............................. & 28 \\
\hline Medicine Bow River …………………….... & 2 \\
\hline 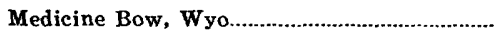 & 2,5 \\
\hline 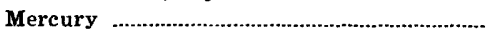 & 66 \\
\hline Metamorphism, Precambrian ……….. 4, 7,2 & \\
\hline Microcline ……ㄴ..1 & 2,68 \\
\hline Minerals, accessory to ore & \\
\hline altered sandstone & 2 \\
\hline 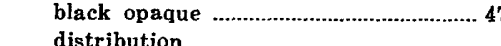 & \\
\hline $\begin{array}{l}\text { distribution } \\
\text { epigenetic }\end{array}$ & \\
\hline sequence of deposition ................................ & 58 \\
\hline syngenetic & \\
\hline
\end{tabular}
See also specific mineral names.

Mining. See Uranium, extraction.

Minnekahta Limestone Member,

Goose Egg Formation …..... 13

Miocene, uranium deposition ...................... $\quad 70$

Missouri River …………………………....... 18, 26

Molybdenum …............................................ 71

Monazite …….............................................. 41, 74

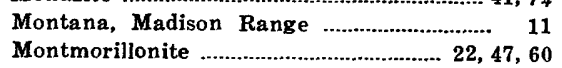

Morrison, Colo.................................................. 15

Morrison Formation ……….......................... 1, 15, 35

Moss Agate Ridge ………………................ 27, 74

Mowrie beds …….......................................... 17

Mowry Shale ............................................... 17 paleotopography ………………………... 42 slide blocks ............................................... 35 stratigraphic position ….................................... 1 White River Formation .............................. 26

Mud cracks ............................................. 16, 17

Muddy Sandstone Member, Thermopolis Shale …………..... 17

Mudstone, Morrison Formation .................. 15 White River Formation ……......... 26, 28, 29 Multiple migration-accretion theory ........ 72

\section{$\mathbf{N}, \mathbf{O}$}

Nall Lease ..................................................... Nebraska, Arikaree Formation …………….... 32 Brule Formation .................................... 31 Niobrara Formation ................................. 18

New Mexico, Ambrosia Lake .......................... 55, 59 red-bed copper deposits .......................... 70

Night Owl uranium prospect ............................ 12 Niobrara Formation ….............................. 1, 18,42 Niobrara River, Neb .................................. 18 North Dakota, lignite .................................. 68 North Platte River .................................... 2, 19 Nugget Sandstone ……………………..... 14 $\begin{array}{rr} & \text { Page } \\ \text { Ogallala Formation } & 32\end{array}$ Opeche Shale Member, Goose Egg Formation .........12, 13

Oregon Buttes Orella Member, Brule Formation ................ 31 Orellan provincial age ................................ 31, 32 Organic material

See also Carbon.

Orthoclase

41,70

Oxidation

$8,22,68$

$\mathbf{P}$

Paleocontours

Paleotopography …………………………...... 36, 42

Petrified Forest, Wyo ……………………….... 22

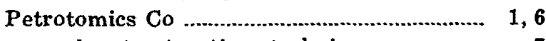

solvent-extraction techniques ……....... 7

Petrotomics Co. open-pit mine, sec. 9, altered sandstone ........ 44 calcite ......................................... 57 carbonaceous material ....................... 48 copper ……............................... 50 distribution of elements ................... 59 $\mathrm{Fe}^{+2} / \mathrm{Fe}^{+3}$ ratio ................................... 49 fossils ........................................... 23 measured section .............................. 21 sulfate ………................................. 63

sec. 15 measured section ……-...-...-...-................ 22

Phosphate …………………………... 41, 63 Pine Butte Member, Sundance Formation 15 Plagioclase ………………………….... 8, 68, 69 Pollen …………................................ 19, 23 Popo Agie Formation ...................................... 14

Potassium ……………………………………... 66 Powder River Basin ……………_...... 42, 55, 68 Precambrian rocks ……………………............. 1

diabase …….......................................... 8, 20

gneiss .....................................................

granite, Arikaree Formation .................. 33 composition ...................................... 8 Laramie Mountains .......................... 4, 8 source of monazites ........................ 74 White River Formation ................. 27, 29 Wind River Formation ............... 20

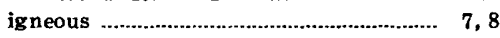
Laramie Mountains ................................. 4, 4 metamorphism ….................. 4, 7, 8, 29, 33 Protore …………………………………..... 53 Pseudomorphs bedding ....................................... 67

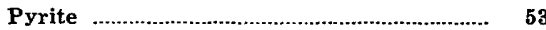
accessory ore mineral ........................... 2, 41 alteration ........................................... 48, 69 association with arsenic ....................... 65 association with hematite ..................... 57 association with iron ............................... 49, 60 association with selenjum .................... 62 in depositional sequence ........................... 58

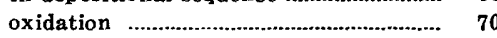
Thermopolis Shale

$\mathbf{Q}$

Quartz

tz ............................................. 8, 22, 68, 73 vein

Quartz diabase

Quartzite

Casper Formation

Madison Limestone

\section{$\mathbf{R}$}

Radioactive dating

Radioactive decay

Radioactivity

Radioelements. See Uranium. Radium, and Radon.

Radium
Radon Page

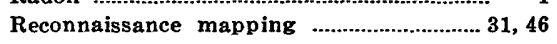

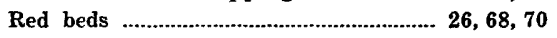
Alcova Limestone ..................................... 13 Goose Egg Formation ................................. 13 Red Creek ………................................. 13 Red Draw Member, Jelm Formation ...... 14 Red Peak, Absaroka Range ....................... 13 Red Peak Formation ................................... 18, 26 faults ……............................................ 35 stratigraphic position …......................... 1, 14 Redox interface ................................... 59, 72 Reduction ............................................. 58, 70, 71 Redwater Shale Member,

Sundance Formation ............. 15

References cited …….................................. 74

Rich ore section …….................................... 53

Rimo, triangulation station ……………...... 28

Ripple marks ....................................14, 15, 16, 17

Roads ........................................................ 2

Russia, selenium deposits ............................... 55 uranium deposits ...................................... 52, 72

$\mathbf{s}$

Sand …...................................... 12, 22, 25, 74 Sand Creek …......................................... 37 Sandstone ……..................................... 42, 56 Alcova Limestone …………………….......... 13 alteration …........................................ 46 Arikaree Formation ................................... 32 Casper Formation ………............................ 12 Cloverly Formation ................................ 16 concretions .............................................. 13, 15

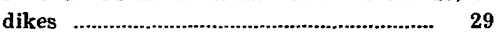
Frontier Formation ................................. 35, 42 Goose Egg Formation ........................... 13 ground water ........................................... 37, 41 Jelm Formation …….............................. 14, 35 Madison Limestone ................................ 11 Morrison Formation ................................... 15 Niobra ra Formation .............................. 18 permeability .......................................... 46, 52 Red Peak Formation …….................... 13 slide blocks ................................................. 35 Steele Shale ……...................................... 18 Sundance Formation .............................. 14 Thermopolis Shale ................................... 17 transmissivity ............................................ 46, 50 Wagon Bed Formation ……………...... 24 White River Formation .......... 26, 29, 34, 74 Wind River Formation ........................ 20, 41

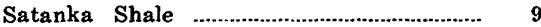
Sedimentation, Laramie Mountains .......... 4 Oligocene …………………………….... 4 Paleozoic ……_................................ 7,9 Tertiary …………….............................. 7 Selenium …………………………..... 55, 62, 70 accessory ore mineral ............................ 2,41 altered sandstone .................................... 49, 67 association with arsenic ........................ 65 epigenetic …………............................... 53 from volcanic ash ................................. 68 in depositional sequence .......................... 58 Seminoe Mountains ............................................. 36 Sericite

Shale, Cloveriy Formation ................................ 16 Frontier Formation .................................. 35 Jelm Formation ..................................... 14 Mowry Shale ............................................ 17, 42 Niobrara Formation ................................ 18, 42 perched water ........................................... 37 slide blocks ................................................. 35

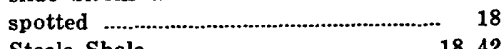
Steele Shale …........................................ 18, 42 Sundance Formation ............................. 14 Thermopolis Shale ……………………...... 17 Wind River Formation .......................... 23 


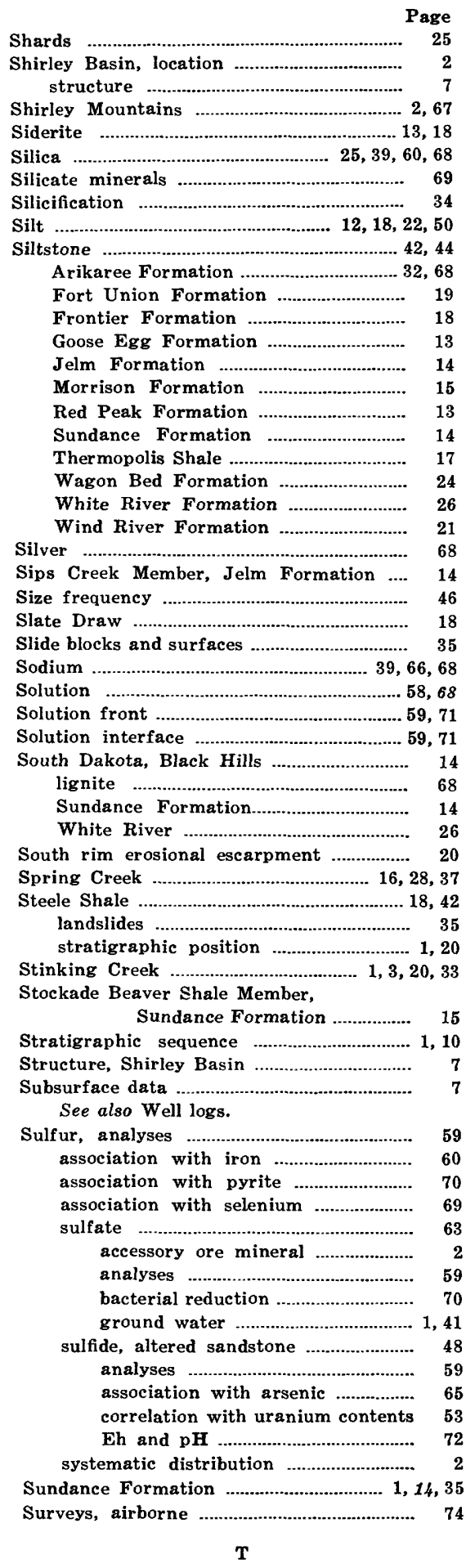

Tensleep Sandstone ......................................... 12

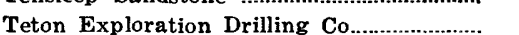

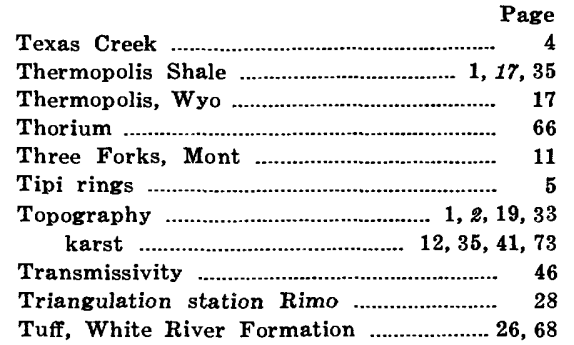

$\mathrm{U}$

Union Pacific Railroad …........................... 2

Uraninite association with black opaque minerals

epigenetic mineral

in depositional sequence

principal ore mineral ............................ 2, 41

Uranium, age .......................................... 2, 73 analyses ............................................... $\quad \mathbf{5 0}$

association with vanadium ................. 65

deposition, dynamic ...................... 58, 71,72

deposition, environment ......................44,68

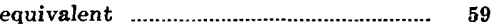

extraction

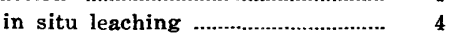

ion exchange .................................. 4, 7 solvent-extraction techniques ........ 7

genesis of ore .................................. $37,57,67$

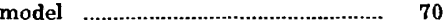

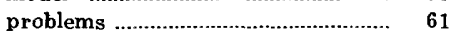

grade of ore .............................. 1, 41, 50, 52

ground water .......................................... 41

minerals .................................... 2, 41, 47 depositional sequence .................. 58

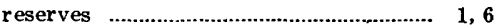

roll-type deposits .................................. 50 boundaries ........................................... 52 $\mathrm{Fe}^{+2} / \mathrm{Fe}^{+3}$ ratio ............................. 49 formation ......................................... 72 location .............................................. 1 solubility ................................................ 68 source ..................................................67, 68 transportation …..................................... 68,70

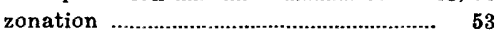

U.S.S.R. See Russia.

Utah Construction and Mining Co ............ 1 development headings ........................... 6 mining methods ................................. 4, 5, 7 observation wells .............................. 37

Utah Construction and Mining Co. mine, altered-sandstone tongue ........ 44

arsenic

calcite

copper

distribution of elements

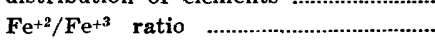

sulfate

Utah Construction and Mining Co. open-pit mines, fossils

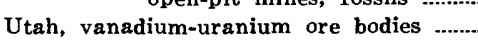
Yellow Cat area

$$
\text { V }
$$

VABM Holiday

Vanadium

$2,50,65,68$
Page

Vegetation ............................................ 5, 8, 22

Veinlets, pyrite-marcasite ........................... 55

Veins, quartz ................................................... 8 Volcanic ash ................................. 32, 33, 68, 69 Vugs

W

Wagon Bed Formation ............................. 24 fossils ....................................................... 25 measured section ..................................... 24, 25 radioactivity .......................................... 73 silicified rock ...................................... 35

stratigraphic position ............................. 1, 28 Wall Creek Sandstone Member, Frontier Formation ........ 18, 42, 70

Wasatch Formation .................................. 67 Water table ................................................. 37 Well logs, electric ........................... 13, 14, 15, 18 gamma-ray ................................................ 6 lithologic .................................................... 6 resistivity .......................................6, 6, 16, 20 self-potential ............................................... 6

Wells, observation …...................................... 37

White River, S. Dak ...................................... 26

White River Formation ................................ 26 comparison with Wind River Formation ................... 23 fossils .................................................... 27 ground water ........................................... 38 landslides ................................................... 35 measured sections ................................ 28, 30 monazites ….......................................... 74 sandstone ................................................. 34

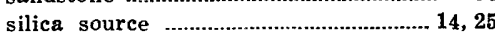
stratigraphic position ............................ 1 uranium source .....................................67, 67 White River Group ................................... 19, 26 Whitmore, Frank C., fossil identification .................23, 31 Whitneyan provincial age ........................... 32 Whitney Member, Brule Formation ....... 31 Wildlife

Wind River Basin .......................................

Wind River deposits ................................. 19

Wind River Formation .................................. 19 carbonate drilling

faults and landslides fossils ....................................................... 23 ground water ........................................... 38 host of uranium deposits ............... 1, 41,67 monazite deposits ................................... 74 sand and gravel ................................... 74 stratigraphic position .................... 1,25,27

Wind River Group ...................................... 19

Wind River Range .................................. 19, 33

Windy Hill Sandstone Member, Sundance Formation .............. 15 Wolfe, Jack A., fossil identification ........ 24

$$
\mathbf{X}, \mathbf{Y}, \mathbf{Z}
$$

X-ray diffraction ......................................... 47, 55

Yellow Cat area, Utah ............................... 68 Yoder Formation .......................................... 27

Zeolites 25 Zircon 8 